' Central Shops Burning/Rubble Pit 631-6G Additonal Sampling and Monitor Well Installation Report

by

E. Palmer

Westinghouse Savannah River Company

Savannah River Site

Aiken, South Carolina 29808

This paper was prepared in connection with work done under the above contract number with the U.S. Department of Energy. By acceptance of this paper, the publisher and/or recipient acknowledges the U.S. Government's right to retain a nonexclusive, royalty-free license in and to any copyright covering this paper, along with the right to repsodygeand to authorize others to reproduce all or part of the copyrighted paper.
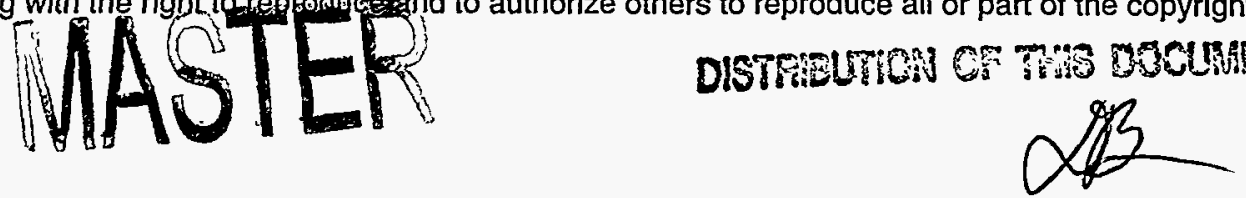


\section{DISCLAIMER}

This report was prepared as an account of work sponsored by an agency of the United States Government. Neither the United States Government nor any agency thereof, nor any of their employees, makes any warranty, express or implied, or assumes any legal liability or responsibility for the accuracy, completeness, or usefulness of any information, apparatus, product, or process disclosed, or represents that its use would not infringe privately owned rights. Reference herein to any specific commercial product, process, or service by trade name, trademark, manufacturer, or otherwise does not necessarily constitute or imply its endorsement, recommendation, or favoring by the United States Government or any agency thereof. The views and opinions of authors expressed herein do not necessarily state or reflect those of the United States Government or any agency thereof.

This report has been reproduced directly from the best available copy.

Available to DOE and DOE contractors from the Office of Scientific and Technical Information, P. O. Box 62, Oak Ridge, TN 37831; prices available from (423) 576-8401.

Available to the public from the National Technical Information Service, U. S. Department of Commerce, 5285 Port Royal Road, Springfield, VA 22161. 


\section{DISCLAIMER}

Portions of this document may be illegible electronic image products. Images are produced from the best available original document. 


\section{CENTRAL SHOPS BURNING/RUBBLE PIT 631-6G ADDITIONAL SAMPLING AND \\ MONITOR WELL INSTALLATION REPORT (U)}

\section{SAVANNAH RIVER SITE}

IRINAI

FEBRUARY 1995

Prepared for:

Westinghouse Savannah River Company

Savannah River Site

Aiken, South Carolina

Prepared by:

RUST Environment \& Infrastructure

33 Varden Drive

Aiken, South Carolina 


\section{TABLE OF CONTENTS}

EXECUTIVE SUMMARY

ES-1

$\begin{array}{lll}1.0 & \text { INTRODUCTION } & 1\end{array}$

1.1 Previous Sampling/Screening Activities 1

1.2 Project Scope and Objectives 5

$\begin{array}{lll}1.3 & \text { Site Location } & 8\end{array}$

1.4 Geology and Hydrogeology . 9

1.4.1 Geology 9

1.4.1.1 Geology of the SRS 9

1.4.1.2 Unit Geology 13

$\begin{array}{ll}\text { 1.4.2 Hydrostratigraphy } & 13\end{array}$

1.4.2.1 Hydrostratigraphy of SRS 13

1.4.2.2 Local Hydrostratigraphy 24

$\begin{array}{lll}2.0 & \text { FIELD METHODS } & 27\end{array}$

2.1 Drilling and Geologic Sampling 27

$\begin{array}{ll}2.2 & \text { Temporary Groundwater Monitoring Well Design, Installation, and } \\ \text { Sampling } & 31\end{array}$

2.2.1 Temporary Groundwater Monitoring Well Construction 31

2.2.2 Well Development 34

2.2.3 Groundwater Sampling 36

2.2.4 Field Permeability Testing 36

2.3 Soil Sampling 38

2.3.1 Soil Sample Locations and Intervals 38

2.3.2 Soil Sampling Procedures 42

2.3.3 Soil Sample Results 43

2.4 Surface Water/Sediment Sampling . 50

2.4.1 Sampling Locations and Intervals 50

2.4.2 Sampling Procedures 50 
$2.5 \quad$ Boring Activity/Problems $\quad 52$

2.5.1 Temporary Groundwater Monitoring Wells 52

2.5.2 Soil Borings 53

2.5.2.1 Soil Borings Located Within the Estimated Boundary of BRP6G

2.5.2.2 Soil Borings Located Outside the Estimated Boundary of BRP6G

2.5.2.3 Background Soil Boring Locations

55

2.5.2.4 Soil Boring in Drainage Feature

\section{APPENDICES}


List of Figures

Page

Figure 1 SRS Location Map

Figure 2 Location of the Burning/Rubble Pit (BRP6G) in the Central Shops Area of SRS

Figure 3 Waste Unit Topographical Map

Figure 4 Surface Water/Sediment Sampling and Background Soil Sample Locations

Figure 5 General Stratigraphic Column for Coastal Plain Sediments

Figure 6 Lithologic and Hydrologic Cross Section HXB-5D to CBR-3D

Figure 7 Lithologic and Hydrologic Cross Section CBR-3D, CBR-2D, and CBR-1D

Figure 8 Stratigraphic Column of the SRS Area with Hydrologic Nomenclature

Figure 9 Profile of P-18 Well Cluster

Figure 10 Regional Potentiometric Surface Map Aquifer Unit IIA

Figure 11 Regional Potentiometric Surface Map Aquifer Unit IB

Figure 12 Regional Potentiometric Surface Map Upper Aquifer Unit IA

Figure 13 Regional Potentiometric Surface Map Lower Aquifer Unit IA

Figure 14 Potentiometric Surface of the Water Table (Aquifer Unit IIB) in the $\mathrm{BRP} 6 \mathrm{G}$ area

Figure 15 Potentiometric Surface of the Water Table (Aquifer Unit IIB) at the BRP6G

Figure 16 Soil Sampling Depths and Analytical Parameters

Figure 17 Location of Pit Boundary 
List of Tables

Page

Table 1 Summary of Groundwater Monitoring Well Installation 29

Table 2 Coordinates and Elevation Details $\quad$. 32

Table 3 Summary of Well Development 35

Table 4 Groundwater Monitoring Well Hydraulic Conductivity Estimates 39

Table $5 \quad$ Summary of Soil and Surface Water/Sediment Sampling 44 


\section{List of Appendices}

Appendix A Addendum to Chapter 4 of the RFI/RI Work Plan for "Additional Soil Sampling and Groundwater Monitoring Well Installation"

Appendix B Daily Field Logs

Appendix C Field Reports for Groundwater Monitoring Wells

Appendix D Field Reports for Individual Boreholes

Appendix E Daily Sign-In/Out Logs and Work Zone Entry/Exit Logs

Appendix F Well Development Forms

Appendix G Groundwater Sampling Information

Appendix H Field Permeability Testing

Appendix I Surface Water/Sediment Sampling Information 


\section{List of Acronyms/Abbreviations}

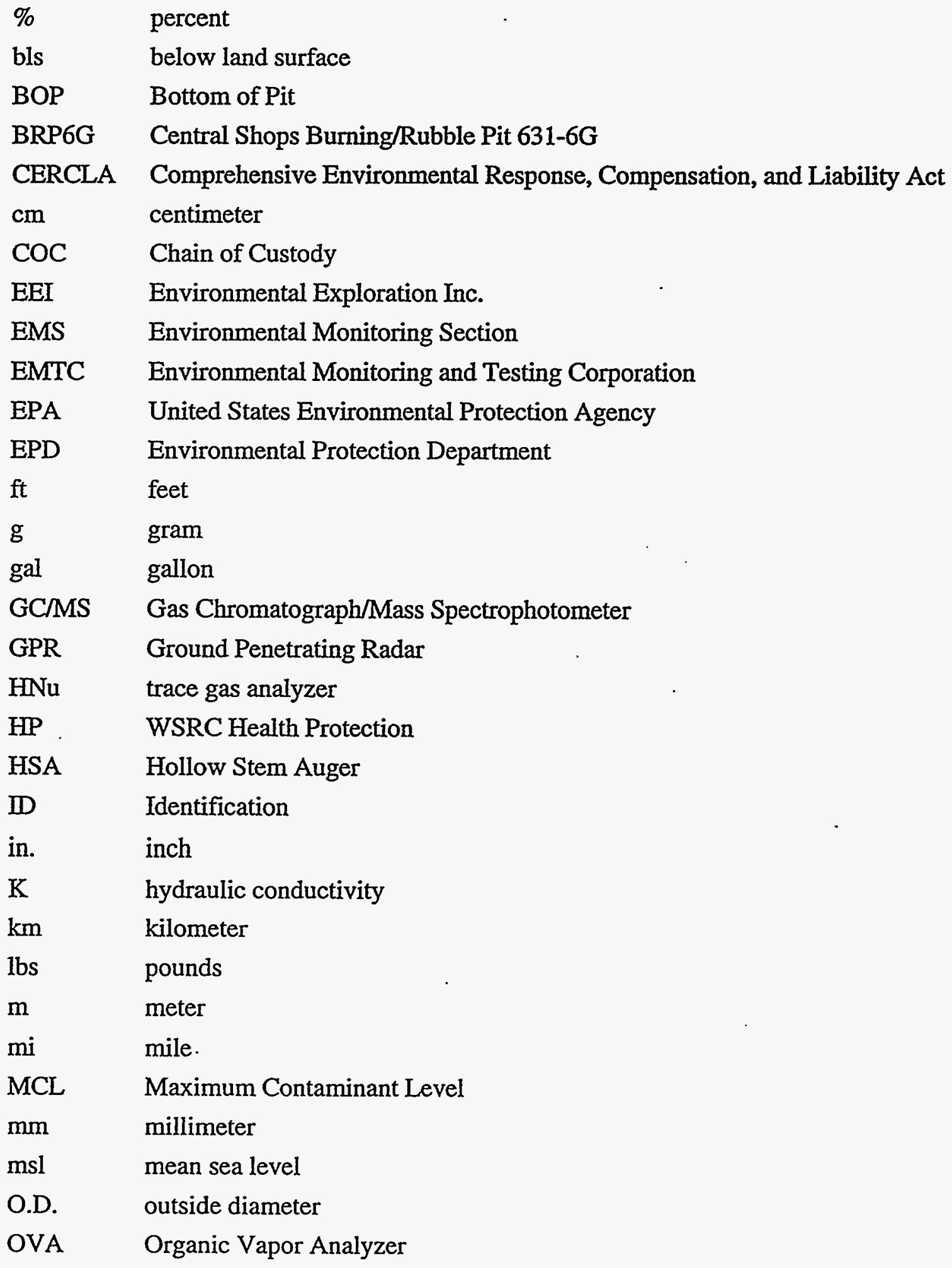


PAH polycyclic hydrocarbons

PCBs polychlorinated biphenyls

ppm parts per million

PVC polyvinyl chloride

QA/QC Quality Assurance/Quality Control

RCRA Resource Conservation and Recovery Act

RFI RCRA Facility Investigation

RI Remedial Investigation

RUST E\&I RUST Environment \& Infrastructure

SCDHEC South Carolina Department of Health and Environmental Control

sec second

SRS Savannah River Site

STR Subcontract Technical Representative

SWMU Solid Waste Management Unit

TAL Target Analyte List

TCL Target Compound List

TDS Total Dissolved Solids

TIC Tentatively Identified Compounds

TOC Total Organic Carbon

TOH Total Organic Halogens

TSS Total Suspended Solids

USCS Unified Soil Classification System .

VOC Volatile Organic Compound

WSRC Westinghouse Savannah River Company 


\section{EXECUTIVE SUMMARY}

The Central Shops Burning/Rubble Pit 631-6G (BRP6G) was constructed in 1951 as an unlined earthen pit in surficial sediments for disposal and incineration of potentially hazardous substances, such as metals and organic solvents. The BRP6G was removed from serv ice and backfilled in 1955. Some of the hazardous substances, if present, may have migrated into the surrounding soil and/or groundwater. Because of this possibility, the United States Environmental Protection Agency (EPA) has designated the BRP6G as a Solid Waste Management Unit (SWMU) subject to the Resource Conservation Recovery Act/ Comprehensive Environmental Response, Compensation, and Liability Act (RCRA/CERCLA) process.

Preliminary results from the 1994 unit characterization indicate contamination is present in the RCRA Facility Investigation/Remedial Investigation (RFI/RD) unit soils. As stipulated in the Revision 1 RFI/RI Work Plan (1993a), a downgradient groundwater monitoring well will be installed in the water table aquifer because contamination was detected in the unit soils. To help determine the permanent location for this groundwater monitoring well, three temporary groundwater monitoring wells were installed (one to the west, one to the south, and one to the southeast). Water level data from these wells helped determine the hydraulic gradient of the groundwater. These wells were sampled for volatile organic compounds, and later, one or more of the wells will be chosen as the permanent groundwater monitoring well.

Historical aerial photographs implied that the waste unit was actually larger than previously marked and investigated, and indicated the need for further characterization. Based on this additional information from the historical aerial photographs, an additional sampling plan and monitor well installation plan was devised to incorporate the required groundwater monitoring well installation, surface water and sediment sampling, and further soil boring investigation.

As proposed in the Central Shops 631-6G RFI/RI Work Plan, Additional Sampling and Monitor Well Installation Plan, 12 soil borings and three temporary groundwater monitoring wells were installed and sampled. Surficial soil samples were collected at six locations within the ditch located along the railroad, south of the unit. Also, five surface water/sediment samples were collected from the ephemeral stream southeast of the unit. Slug tests were performed at each well and the data was reduced by the Bouwer-Rice method to calculate hydraulic conductivity. Field activities were performed from November 2, 1994 through December 28, 1994 under 
Subcontract AA46326P, Task Order 72. Field activities were overseen by RUST Environment \& Infrastructure (RUST E\&I) personnel.

Data collected and compiled during the project include: soil and groundwater sample collection, surface water and sediment sampling, visual description and logging of soil samples collected via hand auger and split-spoon sampling, hydraulic slug testing and associated data reduction. Field daily activity logs, geologic logs, soil boring installation reports, well installation reports, well development, and monitoring data are presented in this report. 


\subsection{INTRODUCTION}

The Central Shops Burning/Rubble Pit 631-6G (BRP6G) is located in the Central Shops Area near the center of the Savannah River Site (SRS) (Figure 1). The BRP6G Solid Waste Management Unit (SWMU) is on the southeastern side of a divide that separates the drainage basins of the Pen Branch Creek [approximately $1.6 \mathrm{~km}(1 \mathrm{mi})$ to the southeast] and Fourmile Branch [approximately $4 \mathrm{~km}(2.5 \mathrm{mi})$ to the northwest] (Figure 2). The ground elevation is approximately $88.4 \mathrm{~m} \mathrm{[290}$ feet (ft)] above mean sea level (msl) (Gordon et al., 1987). Surface drainage is southward to an unnamed tributary of Pen Branch.

The BRP6G was constructed as an unlined earthen pit, or pits, dug into surficial sediments that were then filled with various waste materials. The location of the BRP6G is shown in relation to major SRS facilities on Figure 1. The region around the BRP6G is shown on Figure 2 and a map of the BRP6G area is shown on Figure 3.

The BRP6G operated from 1951 through 1955 for disposal and burning of waste materials. The unit consisted of a shallow excavation, approximately $3 \mathrm{~m}(10 \mathrm{ft})$. Waste oils, rags, paper, cardboard, plastics, degreasers, wood, rubber, and drummed organic solvents were disposed of in the pit and periodically burned. The volume of waste disposed of at BRP6G was not reported. After disposal activities ceased, the area was covered with soil: The materials incinerated in the burning/rubble pit included potentially hazardous substances, such as organic solvents. Some of the hazardous substances, if present, may have migrated into the surrounding soil, and/or groundwater. Because of this possibility, the United States Environmental Protection Agency (EPA) has designated the BRP6G as a SWMU subject to the Resource Conservation and Recovery Act/Comprehensive Environmental Response, Compensation, and Liability Act (RCRA/CERCLA) process.

\subsection{Previous Sampling/Screening Activities}

Three groundwater monitoring wells (CBR-1D, CBR-2D, and CBR-3D) were installed at the BRP6G in January/February of 1990. The locations of these wells are shown on Figure 3. The analytical data available for the CBR-series wells indicate that sporadic occurrences of contaminants such as 2,4-dichlorophenoxyacetic acid, 1,1,2,2-tetrachloroethane, beryllium, bis(2ethylhexyl)phthalate (a common laboratory contaminant), chromium, gross alpha, mercury, silver, tetrachloroethylene, toluene, and trichloroethylene were detected. These occurrences were not 


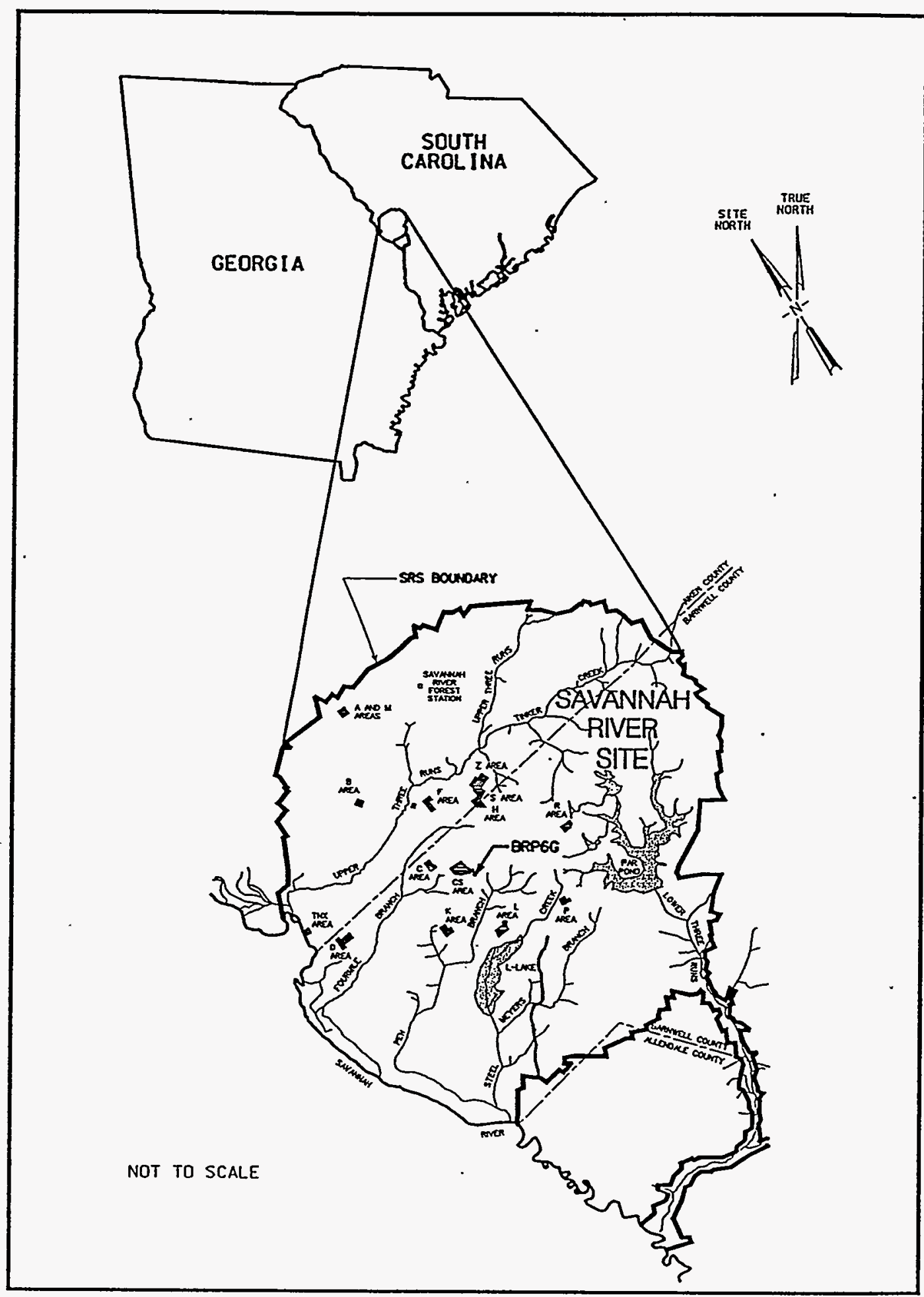

Figure 1. SRS Location Map 


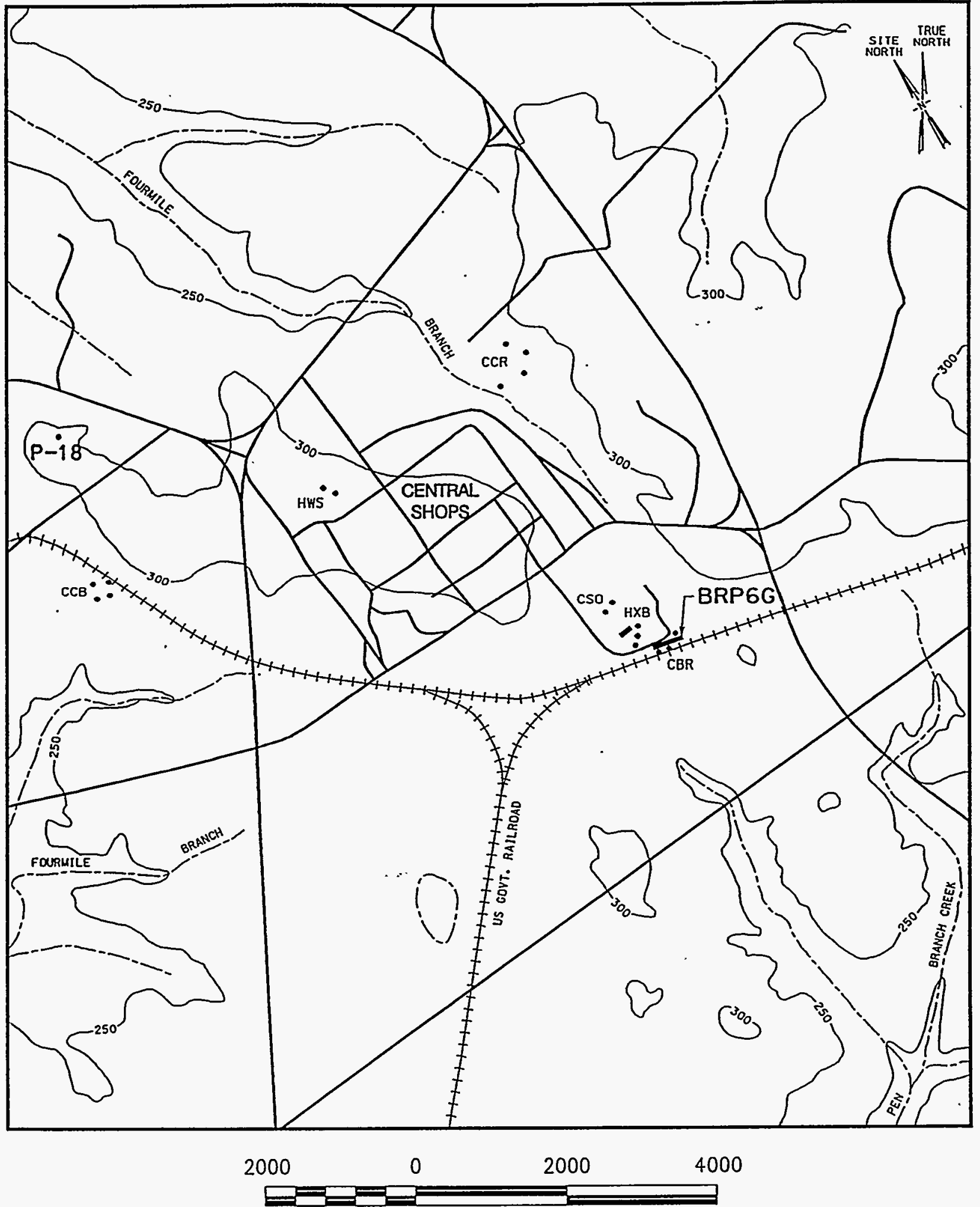

SCALE IN FEET

Figure 2. Location of the Burning/Rubble Pit (BRP6G) in the Central Shops Area of SRS 


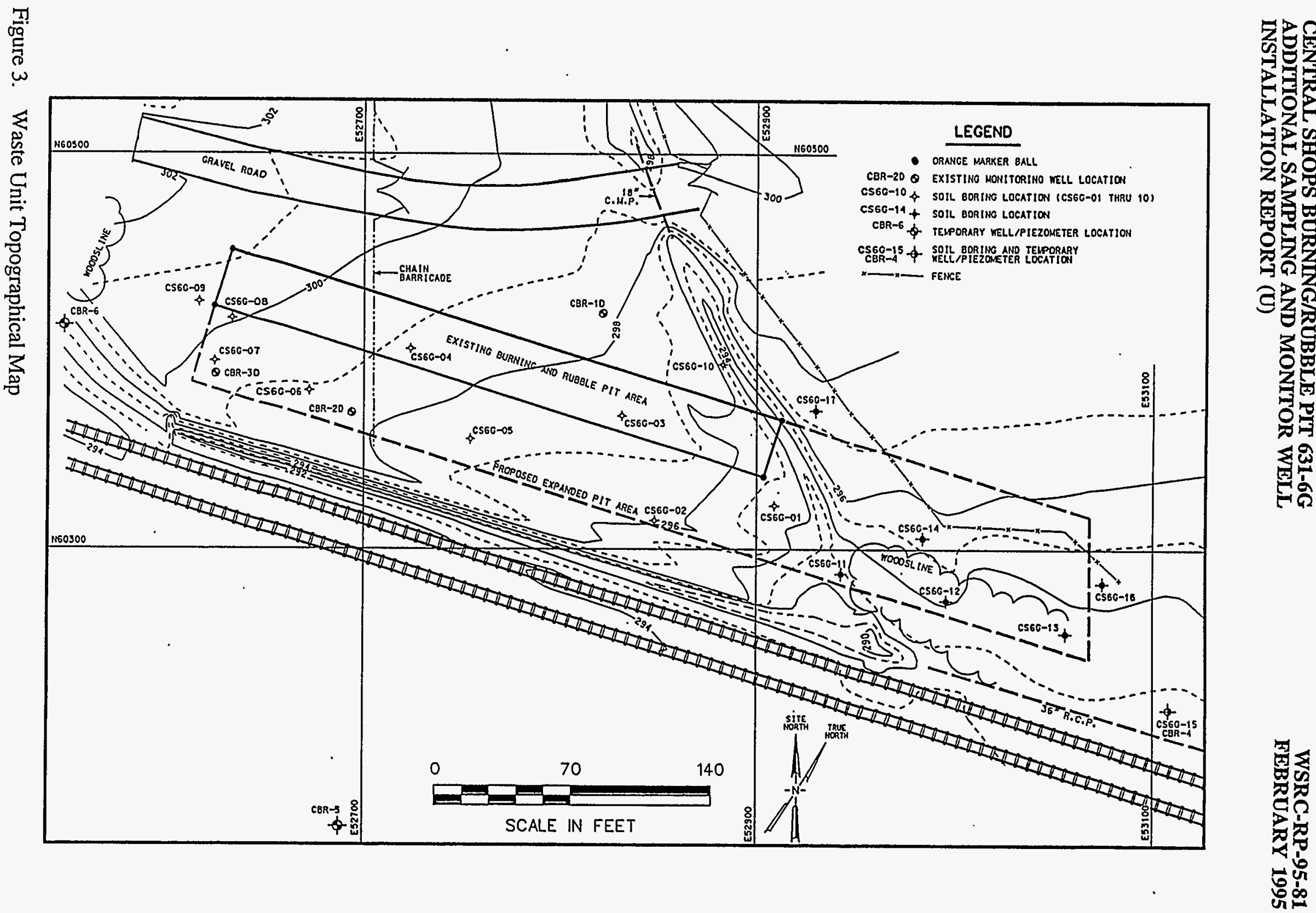


confirmed by subsequent sampling and were often contradicted by duplicate sample results. The data suggest a potential increase in concentration from the upgradient to the downgradient wells for chloride, iron, magnesium, nitrate, potassium, and tritium.

Dichloromethane (methylene chloride), a common laboratory contaminant, was detected in 14 of 52 samples. Of the 14 results above the detection limit, only samples collected from CBR-2D during the first quarter of 1991 exceeded the Maximum Contaminant Level (MCL) for dichloromethane.

Ten shallow soil borings were installed in the BRP6G in March/April 1994. The locations of these borings (CS6G-01 through CS6G-10) are shown on Figure 3. The objective of the soil sampling investigation was: (1) to confirm the results of the soil gas survey, (2) to determine if hazardous substances such as metals, polychlorinated biphenyls (PCBs), pesticides, dioxins/furans, or radionuclides are present in the soils at the $B R P 6 G$, (3) to collect preliminary soil engineering parameters which will be used to screen potential remedial alternatives, and (4) to characterize any potential sources of contamination at the BRP6G and determine the locations of these sources. Review of the analytical data indicates minimal impact to the environment due to pit operations.

The draft report, "Historical Photographic Search of Central Shops Waste Unit 631-6G, Interim Report" (WSRC, 1994b) describes the search through aerial photographs of the Central Shops Area, These photographs provide representation of the changes in the waste unit over time. The photographic review of the area indicates that the waste unit is not accurately marked in the field, and the location is more likely to extend an additional $30.5-38.1 \mathrm{~m}(100-125 \mathrm{ft})$ further east of the waste unit markers (orange balls). In addition, the ditch immediately adjacent to the eastern most edge of the marked unit runs through what may have been the center of the original waste unit and part of the waste unit is more than likely being used currently (1994) as a laydown yard.

All of the details and documentation associated with the technical oversight of the geologic sampling, soil boring installation, temporary monitor well installation groundwater sampling, and field permeability testing of the project are included in this report.

\subsection{Project Scope and Objectives}

RUST Environment \& Infrastructure (RUST E\&I) was retained by Westinghouse Savannah River Company (WSRC) under Subcontract AA46326P to provide geologic and technical oversight for 
the BRP6G RCRA Facility Investigation/Remedial Investigation (RFI/RD) Work Plan additional unit assessment activities (Appendix A). Additional sampling was proposed for the RCRA/CERLCA unit (Addendum to Chapter 4 of the RFI/RI Work Plan For Central Shops Burning/Rubble Pit, 631-6G). This proposed sampling was suggested based on information obtained during unit characterization sampling conducted in March and April 1994 (WSRC, 1994a) and recent observations in the historical aerial photography of the area.

The project scope included technical oversight of the installation of 11 soil borings using hollow stem auger (HSA) drilling techniques, one soil boring performed by hand auger, collection of six surficial soil samples within the ditch (downgradient from the pit), and installation of three temporary groundwater monitoring wells (see.Figures 3 and 4). Five surface water and sediment samples were also obtained from the ephemeral stream, located approximately $60 \mathrm{~m}$ (200 ft) southeast of the pit (Figure 4). The data collected during this study included lithologic detail and soil samples from hand auger and split-spoon samples. Following development of the temporary groundwater monitoring wells, groundwater samples were collected. These wells were also slug tested to gain hydraulic conductivity information. The technical oversight also collected the required Quality Assurance/Quality Control (QA/QC) samples as specified in the proposed additional soil sampling and groundwater monitoring well installation for the BRP6G. The Environmental Protection Department/Environmental Monitoring Section (EPD/EMS) Soil Sample Logbooks and validation materials were used for all sampling documentation.

The RUST E\&I technical oversight coordinated with WSRC and the drilling subcontractor to ensure that:

- the materials and equipment were decontaminated prior to use

- the drilling, sampling, and borehole abandonments were conducted in an efficient manner and in accordance with WSRC 3 Q5 and the RFI/RI Program Plan (WSRC, 1993a)

- $\quad$ proper records were maintained

- $\quad$ composites of the soil samples taken were screened by WSRC Health Protection (HP) prior to offsite shipment of the analytical samples

The objectives of this field investigation were: 


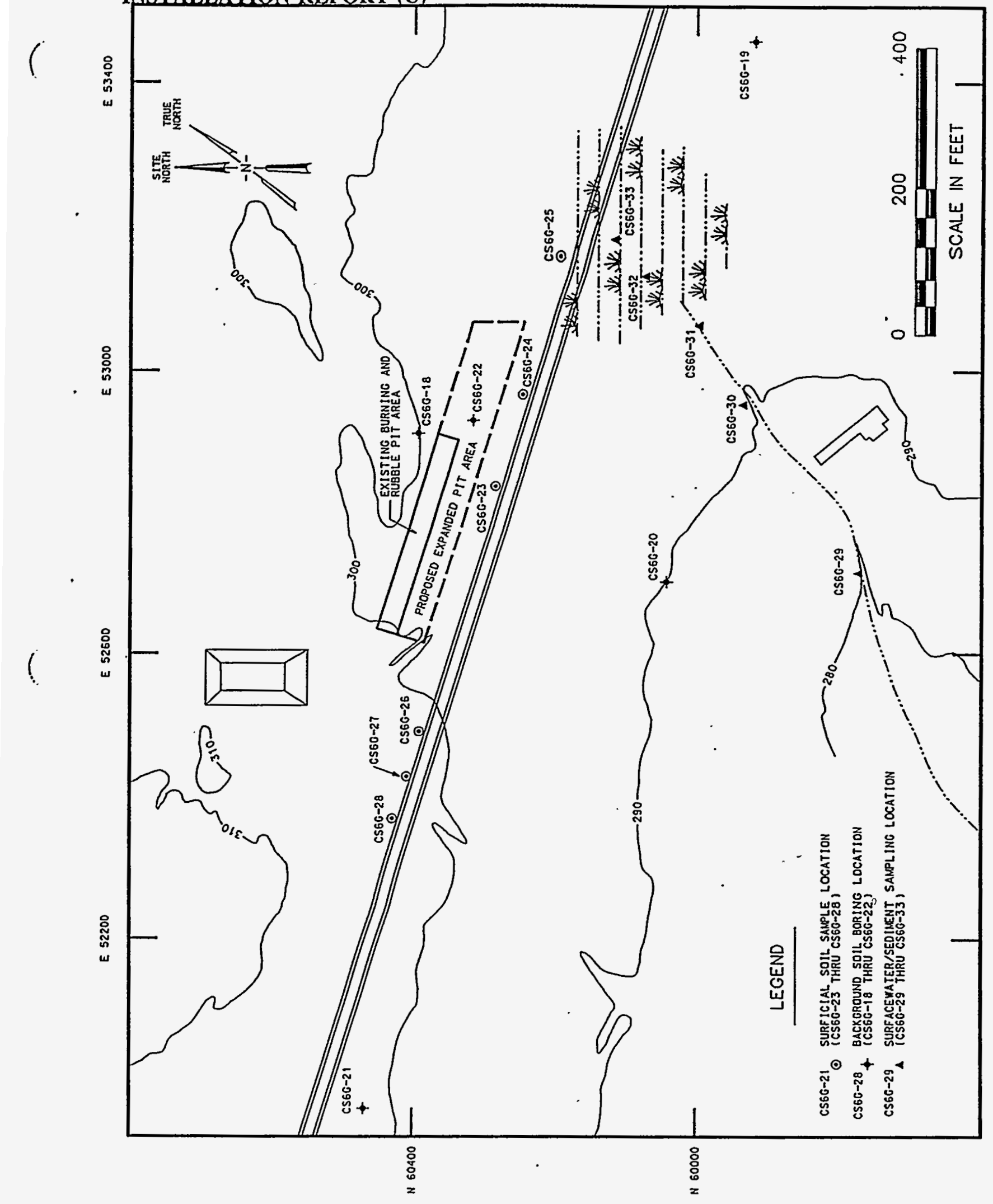

Figure 4 Surface Water/Sediment Sampling and Background Soil Sample Locations 
- to obtain soil samples for laboratory analysis

- to install three temporary groundwater monitoring wells and collect groundwater samples for laboratory analyses

- to collect surficial soil samples at six locations within the ditch located along the railroad, south of the pit for laboratory analysis

- to collect at least five surface water/sediment samples along the ephemeral stream located approximately $61 \mathrm{~m}(200 \mathrm{ft})$ southeast of the pit for laboratory analysis

- to perform field permeability tests (slug tests) on the three temporary groundwater monitoring wells

The depths and analyses for this project are described in the proposed additional soil sampling and groundwater monitoring well installations for the BRP6G and in the RFI/RI Work Plan for the BRP6G and as directed by the subcontract technical representative (STR) for the project. This field investigation was designed to provide data that will:

- confirm the presence or absence of hazardous substances in soil within the unit as indicated by the preliminary results of the 1994 unit characterization

- define the pit boundaries in light of the new data provided by historical aerial photographs

- aid in determining hydraulic conductivity (via water levels and field permeability testing)

- . identify if a potential source(s) of contamination is present at the BRP6G

\subsection{Site Location}

The BRP6G is located in the Central Shops Area. The surface drainage is southward to an unnamed tributary of Pen Branch.

Dothan Soil (soil group three of Looney et al., 1989) is at the surface at BRP6G. A review of the soil conservation service soil survey of the Savannah River Plant area indicates that the soils in the BRP6G SWMU are Udorthents (Rogers, 1990). Udorthents are soils comprising heterogeneous materials which are spoil or refuse from excavations and major construction (Rogers, 1990). Specific background soil sample locations were selected in cooperation with a soil taxonomist at the time the sampling is conducted. 
Based on historical accounts, the disposal area at BRP6G was initially considered to be within a rectangular area approximately $83.8 \mathrm{~m}(275 \mathrm{ft}$ ) long and 9.1 to $13.7 \mathrm{~m}$ (30 to $45 \mathrm{ft}$ ) wide. This area is currently delineated by orange marker balls. Data from a ground penetrating radar (GPR) survey indicated that soil in most of the area defined by the RCRA/CERCLA unit marker balls is undisturbed. Therefore, the March/April 1994 unit characterization investigated the two zones that were represented to be disturbed soils on the GPR survey. The delineation of the waste unit was questionable. Historical aerial photographs indicated that the unit was even larger than anticipated. Additional sampling for the BRP6G was amended to investigate these new suggested boundaries.

An ephemeral stream is located approximately $61 \mathrm{~m}(200 \mathrm{ft})$ southeast of the pit (Figure 4). At the time of the unit reconnaissance, it appeared that the drain/ditch was hydrologically influenced solely by surface runoff.

An embankment separates BRP6G from a shallow dry ditch and railroad right-of-way. The top of the embankment is approximately $7.6 \mathrm{~m}(25 \mathrm{ft})$ south of the southern edge of the suspected rectangular pit. The embankment is approximately $1.5 \mathrm{~m}(5 \mathrm{ft})$ high. Soils exposed in the embankment are undisturbed. The shallow dry ditch, which serves to contain drainage from the railroad right-of-way, contains no obvious evidence of contamination. Water has not been observed in the ditch during any unit reconnaissance.

A second dry ditch which was thought to be located east of the BRP6G appears to cut through the unit on the historical aerial photographs. The ditch has eroded away fill material within the pit boundaries. Also, part of the laydown yard on the eastern side of the ditch appears to be part of the waste unit.

\subsection{Geology And Hydrogeology}

\subsubsection{Geology}

\subsubsection{Geology of the SRS}

The geology underlying the SRS includes crystalline basement rock and Triassic sediments overlain by Cretaceous and younger Coastal Plain sediments (Aadland and Bledsoe, 1990). The crystalline basement rock is composed of chlorite-hornblende schist, hornblende gneiss, and lesser amounts of other types of crystalline rock. This bedrock is buried beneath approximately $274 \mathrm{~m}$ 
(900 ft) of sediment. The Triassic bedrock occurs in the southern portion of the SRS. Sediments of the Triassic bedrock are composed of poorly sorted conglomerate, sandstone and mud-rock, and are generally dark red in color.

The stratigraphic units of the Coastal Plain, from oldest to youngest, are the Cape Fear Formation, the Lumbee Group, the Black Mingo Group, the Orangeburg Group, the Barnwell Group, and the Upland Unit (Figure 5). The Cape Fear Formation is composed of Lower Cretaceous poorly sorted, silty to clayey quartz sands and interbedded clays. The Cape Fear thickens across the SRS, ranging from $9.2 \mathrm{~m}(30 \mathrm{ft})$ at the northwest Site boundary to more than $55 \mathrm{~m}(180 \mathrm{ft})$ at the southeast Site boundary.

The Lumbee Group (Upper Cretaceous) is subdivided into the. Middendorf and the Black Creek Formations, and the Steel Creek Member of the Pee Dee Formation. The lower contact between the Middendorf and the Cape Fear is a sharp erosional unconformity. In general, the Lumbee Group is composed of variably colored quartz sands and clays which range in thickness from 116 $\mathrm{m}$ (380 ft) to more than $213 \mathrm{~m}$ (700 ft) from the northwestern Site boundary to the southeastern Site boundary, respectively.

The Black Mingo Group consists of the Ellenton Member of the Rhems Formation (Early Paleocene), the Snapp Member of the Williamsburg Formation (Late Paleocene), and the Four Mile Member of the Fishburne Formation (Late Paleocene to early Eocene). The Ellenton consists mostly of gray, poorly sorted, micaceous, lignitic, silty and clayey quartz sand interbedded with gray clays. The Ellenton is approximately $12.2 \mathrm{~m}$ ( $40 \mathrm{ft}$ ) thick at the northwestern boundary of the SRS and thickens to approximately $30.5 \mathrm{~m}(100 \mathrm{ft})$ at the southeastern boundary. The Williamsburg (Snapp Member) sediments are composed of silty quartz sand interbedded with clays. The Williamsburg thickens from $9.1 \mathrm{~m}$ (30 ft) at the northwestern boundary of SRS to 15.2 $\mathrm{m}(50 \mathrm{ft})$ at the southeastern boundary. The Fishburne (Four Mile Member) sediments are composed of fine to coarse grained, moderately to well sorted, loose sands with an interbedded clayey zone. The Fishburne has been traced in the subsurface into the northwestern area of SRS (Fallaw, 1991).

The Orangeburg Group is subdivided into the lower Middle Eocene Congaree Formation and the upper Middle Eocene Santee Limestone. The Congaree is composed of well sorted, fine-to-coarse quartz sands with thin clay laminae throughout. The Congaree is approximately $18.3 \mathrm{~m} \mathrm{(60} \mathrm{ft)}$ thick at the northwestern boundary of the SRS and thickens to approximately $25.9 \mathrm{~m}(85 \mathrm{ft})$ near 


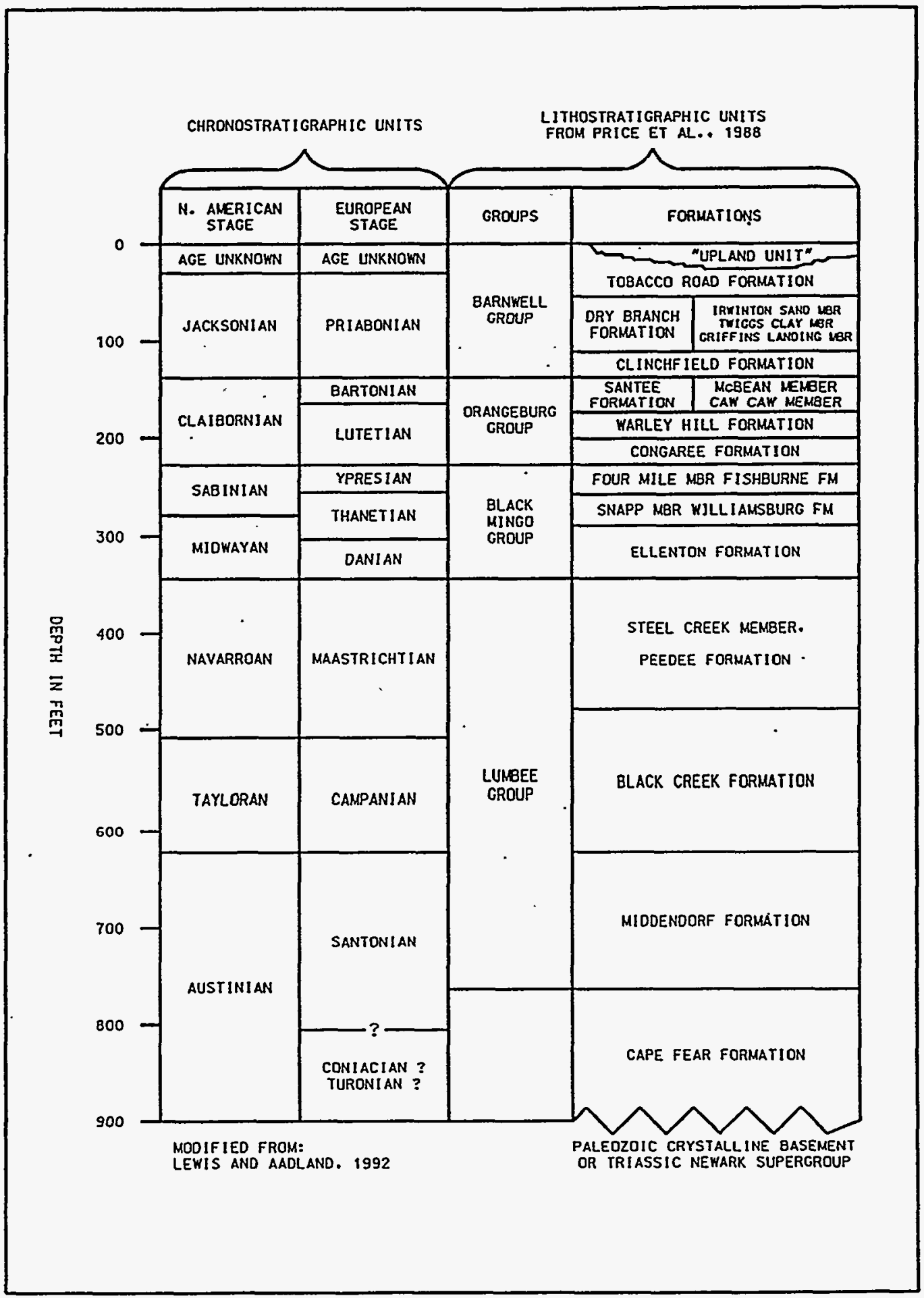

Figure 5. General Stratigraphic Column for Coastal Plain Sediments 
the southeastern boundary. The Santee Formation is subdivided into the Warley Hill, the Caw Caw, and the McBean Members, and varies in lithology from carbonates and calcareous quartz sands to quartz and glauconitic sands and clays. The Warley Hill and the Caw Caw Members make up what has been referred to in many SRS reports as the "Green Clay". This unit is composed of glauconitic, silty and clayey quartz sands. The thickness of the formation ranges from $12.2 \mathrm{~m}$ (40 ft) to more than $24.4 \mathrm{~m}$ ( $80 \mathrm{ft}$ ) from the northwestern boundary of the SRS to the southeastern boundary.

The Barnwell Group (Late Eocene) is subdivided into the Clinchfield, Dry Branch, and Tobacco Road Formations. Quartz sand of the Clinchfield Formation has been distinguished only when contrasting carbonates of the Griffins Landing Member of the Dry Branch Formation and the McBean Member of the Santee Formation occur, with the sand sandwiched between them. This quartz sand was identified at three localities within the SRS, where it is up to $7.6 \mathrm{~m}(25 \mathrm{ft})$ thick, but is not generally mappable. The Dry Branch Formation is subdivided into the Griffins Landing, Twiggs Clay, and Irwinton Sand Members, and varies in lithology from carbonates, silty and clayey quartz sand, and interbedded clays. The carbonate portion of the Griffins Landing Member of the Dry Branch Formation is up to $13.9 \mathrm{~m}$ ( $45 \mathrm{ft}$ ).thick in the southeastern part of the SRS. The Griffins Landing carbonate occurs locally at the SRS and is not known to be present northwest of Tinker Creek and Upper Three Runs Creek within the SRS boundaries. The Twiggs Clay Member, which is tan, light gray, and brown, is up to $3.7 \mathrm{~m}$ (12 ft) thick in the SRS wells but is not laterally continuous. It was referred to as the "Tan Clay" in many SRS reports. The remainder of the Dry Branch Formation within the SRS is made up of the Irwinton Sand Member, which is composed of tan, yellow, and orange, moderately sorted quartz sand, with interlaminated, locally abundant clay. The formation ranges in thickness from $15.2 \mathrm{~m}(50 \mathrm{ft})$ to $24.4 \mathrm{~m}(80 \mathrm{ft})$ from the northwestern boundary of the SRS to the southeastern boundary. The Tobacco Road Formation consists of red, fine to coarse, moderately to poorly sorted quartz sand with minor clay laminae. The Tobacco Road outcrops at the surface at many locations throughout the Site and ranges in thickness from 6.1 to $9.1 \mathrm{~m}$ (20- to $30-\mathrm{ft})$.

The Upland Unit (previously mapped at SRS as the Hawthorn Formation) is composed of clays and poorly sorted, clayey, silty, pebbly, and cobbly quartz sands with extreme lateral and vertical variation. These sediments represent fluvial channel deposits. The presence of the Upland Unit in this area is inconsistent, occurring at higher elevations around the SRS. 


\subsubsection{Unit Geology}

Three monitoring wells (CBR-1D, -2D, -3D) were installed in January and February 1990 at the BRP6G. These wells provide sampling sites for the shallow groundwater aquifer. Locations of these wells are shown on Figure 3. Pilot holes for wells CBR-2D and -3D were drilled at the edge of the large area of disturbed soil. No debris or waste materials were encountered in these boreholes. The wells are currently being used for determining water levels and for monitoring groundwater quality in the Water Table Aquifer. Figures 6 and 7 are lithologic and hydrostratigraphic cross-sections prepared from the monitoring well boring logs. These figures indicate that the wells are screened in the Water Table (Aquifer Zone $\mathrm{mB}_{2}$ ) below a 7.6 to $10.7 \mathrm{~m}$ (25- to 35-ft) thick sandy clay layer.

\subsubsection{Hydrostratigraphy}

\subsubsection{Hydrostratigraphy of SRS}

The SRS is located approximately $48.3 \mathrm{~km}$ (30 miles) southeast of the Fall Line, where sediments of the Coastal Plain Physiographic Province pinch-out, exposing crystalline rocks of the Piedmont Physiographic Province. The recharge zone for the SRS includes the surface area of the site as well as the upgradient land extending northwestward to the Fall Line. Normal annual rainfall for the SRS area is $121.2 \mathrm{~cm}$ (47.7 in.). The Savannah River and its tributaries, Upper Three Runs Creek, Four Mile Creek, Steel Creek, Pen Branch Creek, and Lower Three Runs Creek, provide the main surface water drainage system at the SRS.

A multilayer hydrologic system exists in the Coastal Plain sediments at the SRS. Confining units within the system are interspersed with more transmissive units. Aadland and Bledsoe (1990) developed an alpha numeric hydrostratigraphic nomenclature system for SRS (Figure 8). Within this nomenclature, the basement complex underlying the Coastal Plain deposits is referred to as the Paleozoic-Triassic Basement Hydrogeologic System. This system is overlain by three aquifer systems of Coastal Plain deposits, Aquifer Systems I and II, separated by the Confining System III. These Aquifer systems are separated from the lower Piedmont Hydrogeologic System by the Confining System I. Confining System I is composed of poorly sorted, clayey sediments of the Cape Fear Formation. Confining clay sediments of the middle Black Creek Formation make up Confining Unit IA-IB which separates the Aquifer Units IA and IB. Aquifer System I is composed of sands of the Middendorf Formation and the lower sands of the Black Creek and 


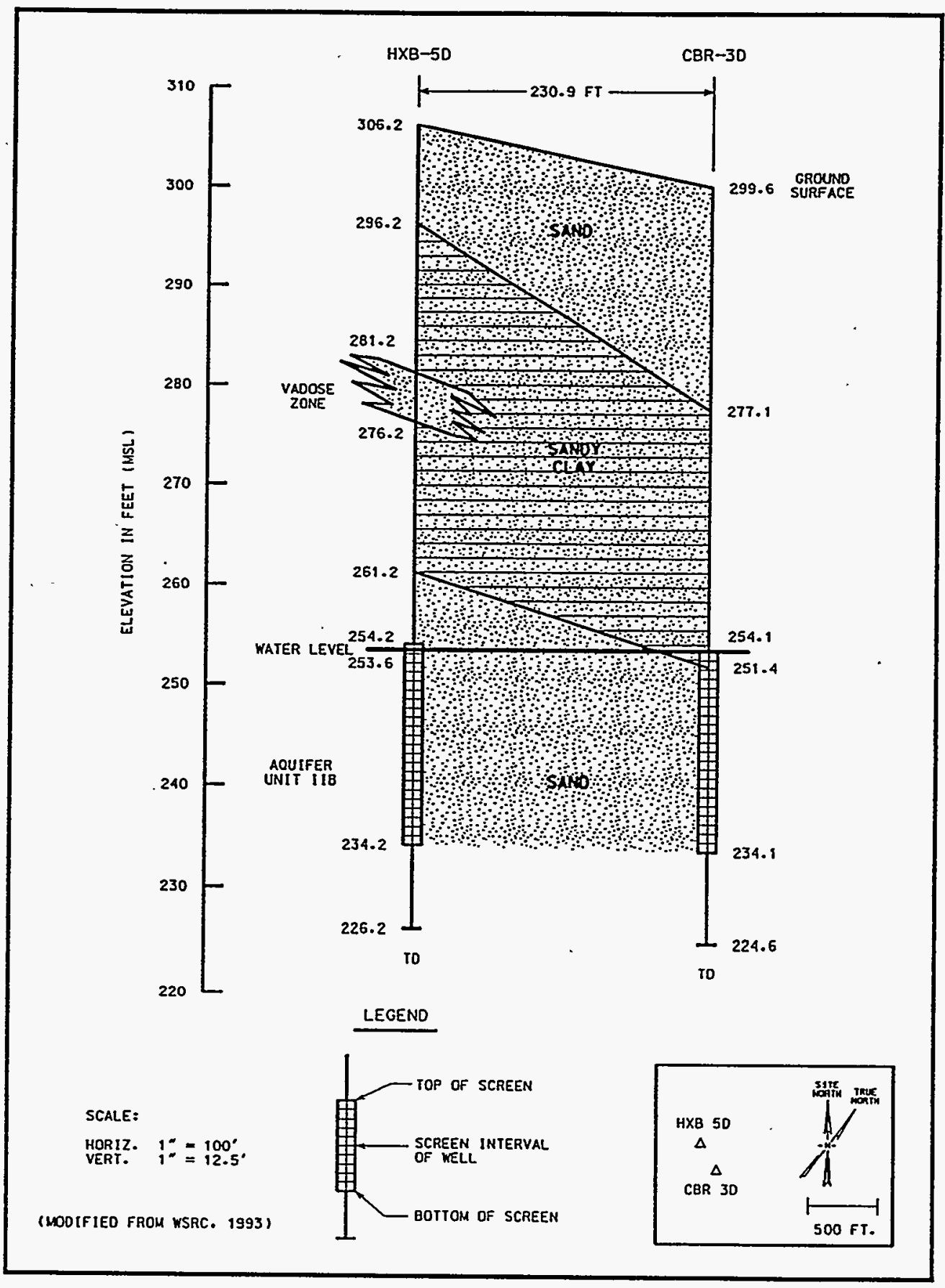

Figure 6. Lithologic and Hydrologic Cross Section HXB-5D to CBR-3D 


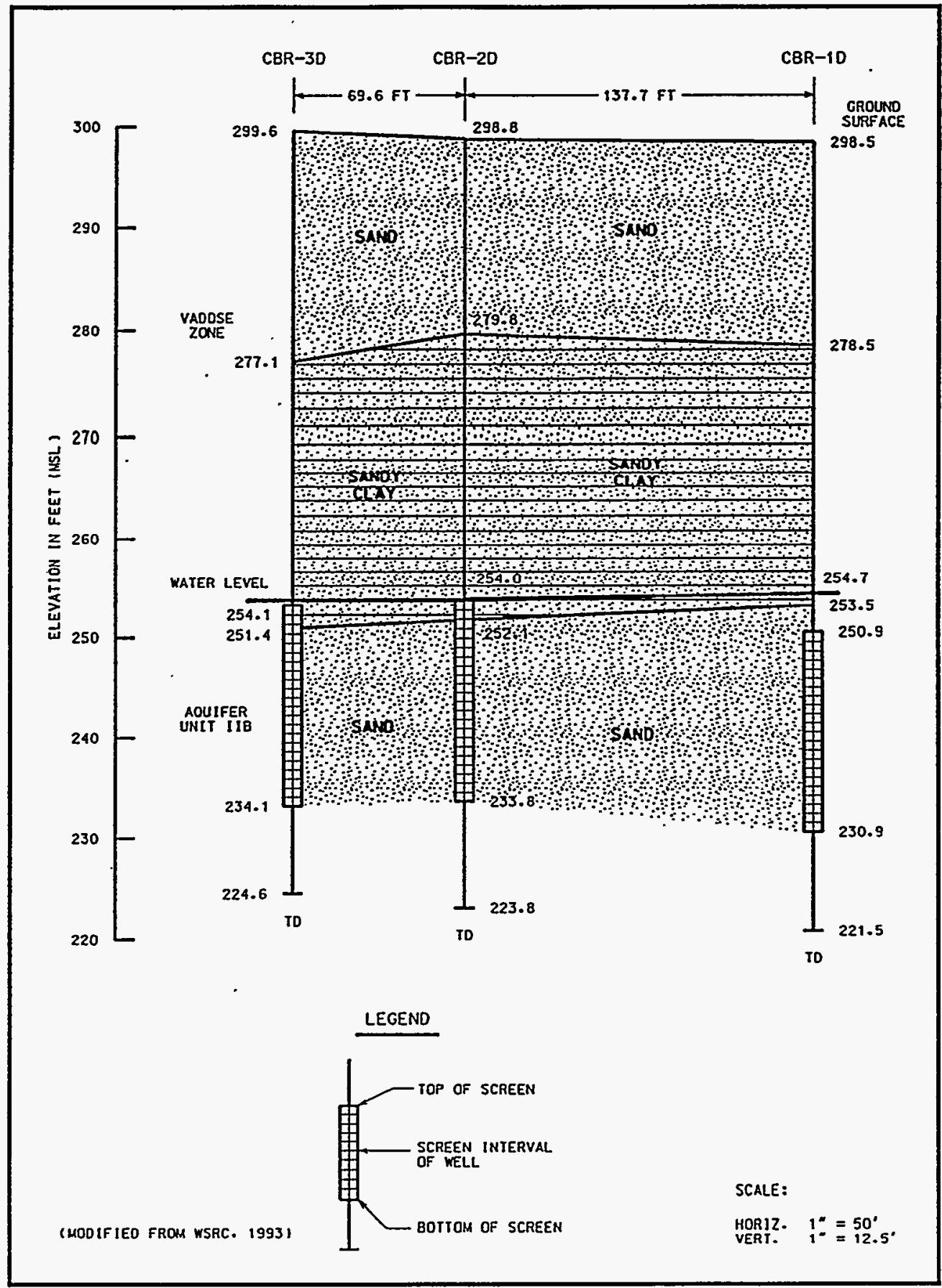

Figure 7. Lithologic and Hydrologic Cross Section CBR-3D, CBR-2D, and CBR-1D 


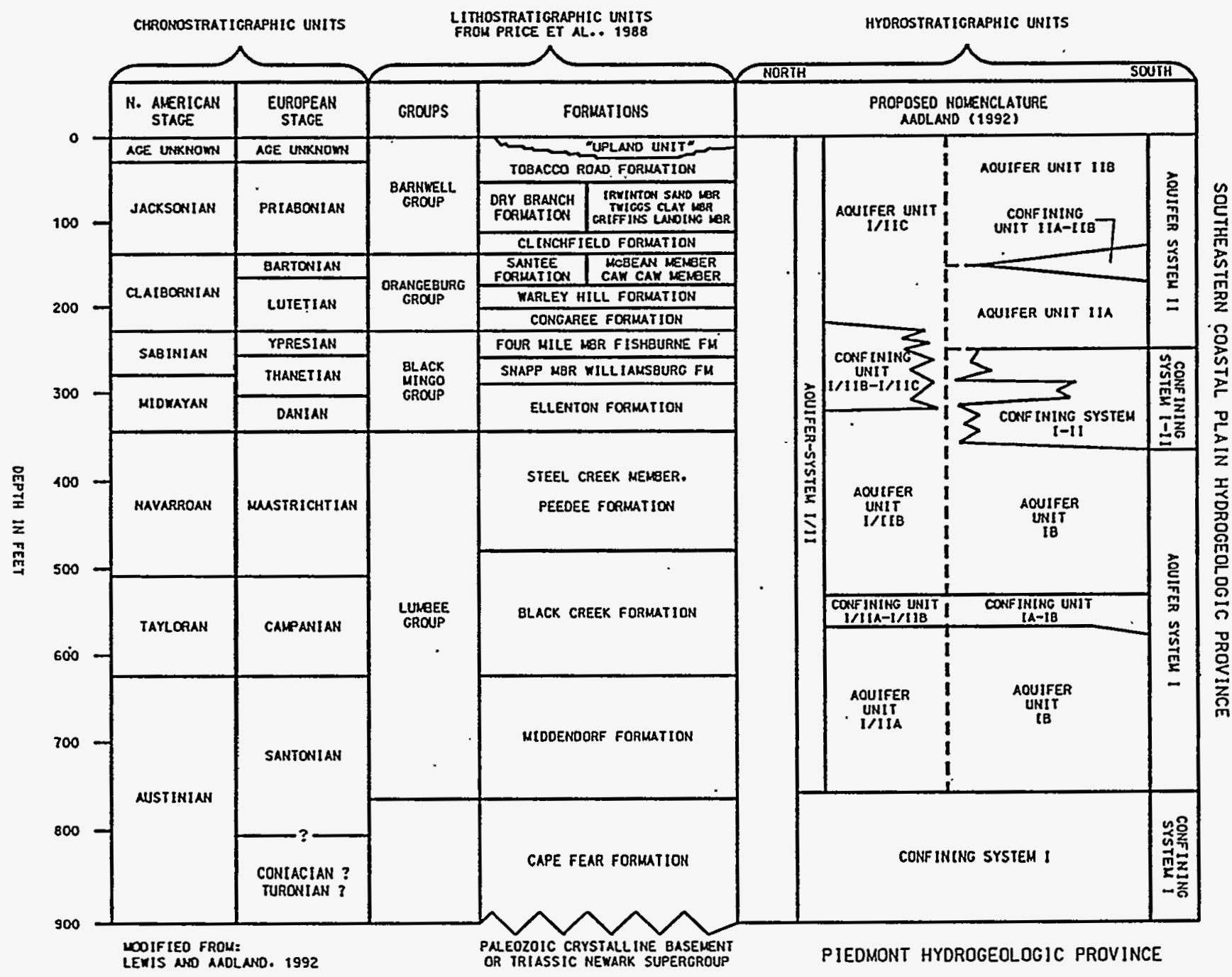

Figure 8. Stratigraphic Column of the SRS Area with Hydrologic Nomenclature 
lower Peedee Formations. The reader is referred to Aadland and Bledsoe (1990) for the most recent description of SRS hydrogeology.

Aquifer Unit IIB includes the shallow Water Table Aquifer at the SRS, which is composed of sediments from the Tobacco Road, Dry Branch, and McBean Formations. The sediments of Aquifer Unit IIB typically exhibit a wide variation in lithologic composition both vertically and laterally. Local hydrostratigraphy of the shallow Water Table Aquifer is discussed in Section 1.4.2.2.

Below the Water Table Aquifer (Aquifer Unit IBB) is Confining Unit IA-IIB. This confining unit is referred to as the "Green Clay". At well cluster P-18 (Figure 9), located approximately $2.4 \mathrm{~km}$ (1.5 mi) west of the BRP6G (Figure 2) the "Green Clay" is an orange clayey sand with clay seams (Bledsoe et al., 1990). A head difference of $15.6 \mathrm{~m}(51.1 \mathrm{ft})$ has been observed between wells P18D and P-18B, screened above and below Confining Unit IIA-IIB. A downward vertical gradient of $1.1 \mathrm{~m} / \mathrm{m}(0.35 \mathrm{ft} / \mathrm{ft})$ is calculated using this head difference. Vertical flow through the clay is not estimated because lithologies in addition to the clay are present between the screened intervals.

Aquifer Unit IIA underlies Confining Unit IA-MB. At P-18, Aquifer Unit IIA consists of a very fine to fine, tan sand with a thickness of approximately $25.9 \mathrm{~m}(85 \mathrm{ft})$. The horizontal and vertical gradients within the aquifer are not known in the vicinity of the BRP6G. A regional calibrated flow model (Haselow and Taylor, 1989) used a horizontal hydraulic conductivity of $4.6 \mathrm{~m} / \mathrm{day}$ ( $15.1 \mathrm{ft} /$ day) and a vertical hydraulic conductivity of $0.3 \mathrm{~cm} /$ day $(0.01 \mathrm{ft} /$ day $)$ in Aquifer IIA (referred to as the Congaree Aquifer) for the regional SRS area. In the vicinity of the BRP6G, regional flow in the aquifer is to the southwest toward the Savannah River (Figure 10).

The Aquifer Unit IIA overlies Confining System I - II. The Confining System I-II is referred to as the Ellenton Confining Unit. As indicated by the P-18 well cluster, Confining System I-II is actually a sequence of interbedded silts, sands and clays. It is approximately $21.3 \mathrm{~m}(70 \mathrm{ft})$ thick in the vicinity of the BRP6G. Undisturbed samples of the Confining System I-II collected at the P-18 well cluster yielded a range of horizontal hydraulic conductivity values of 0.03 to 26.8 $\mathrm{cm} /$ day ( 0.0010 to $0.88 \mathrm{ft} /$ day) and a range of vertical hydraulic conductivity values from 0.0267 to $12.2 \mathrm{~cm} /$ day ( 0.0009 to $0.40 \mathrm{ft} /$ day) (Bledsoe et al., 1990). The downward vertical gradient across the Confining System I-II, as measured at the P-18 well cluster, is 0.013 . Using an effective porosity of 0.10 for sandy clay (Todd, 1959), the vertical flow velocity of Confining 


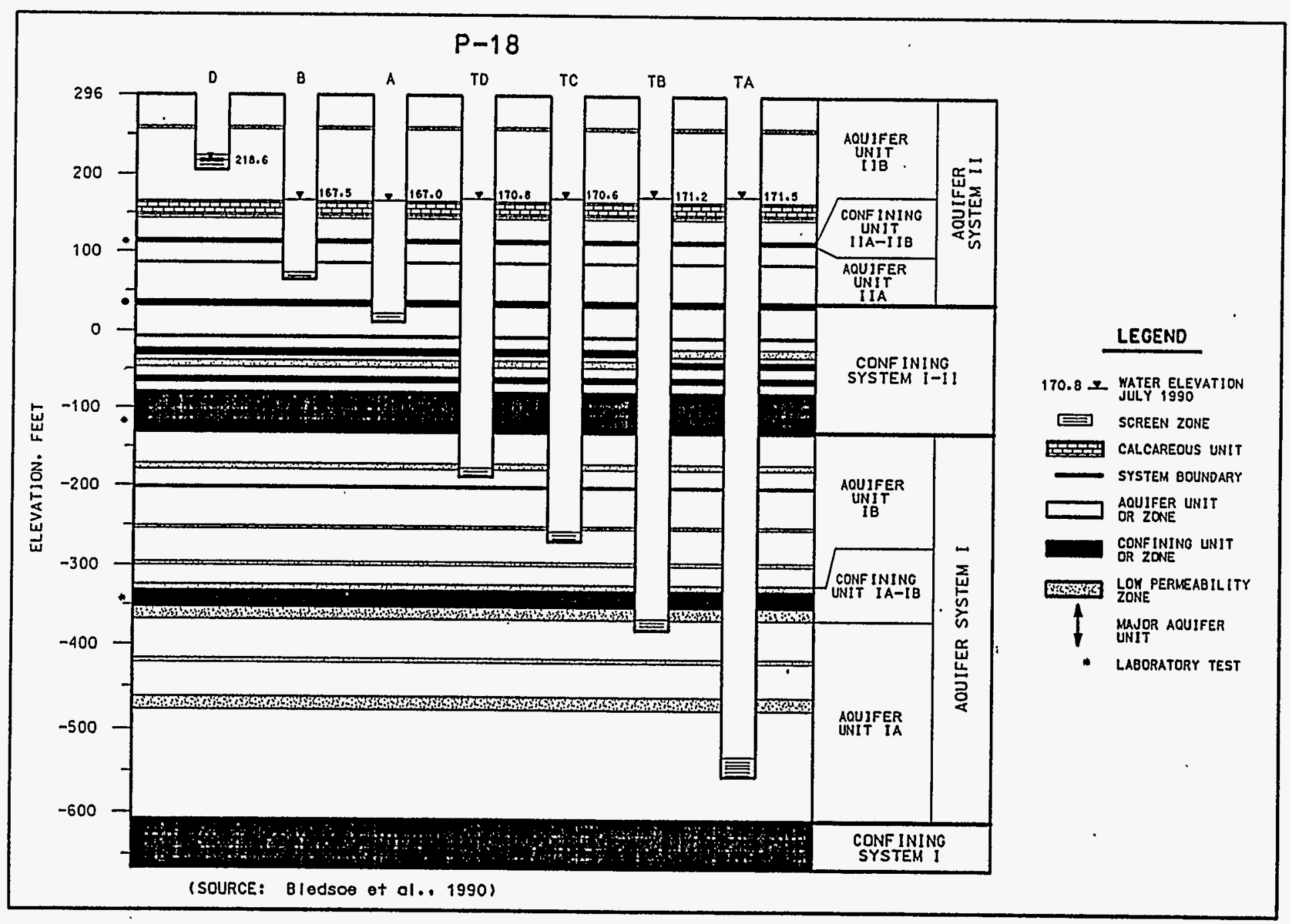




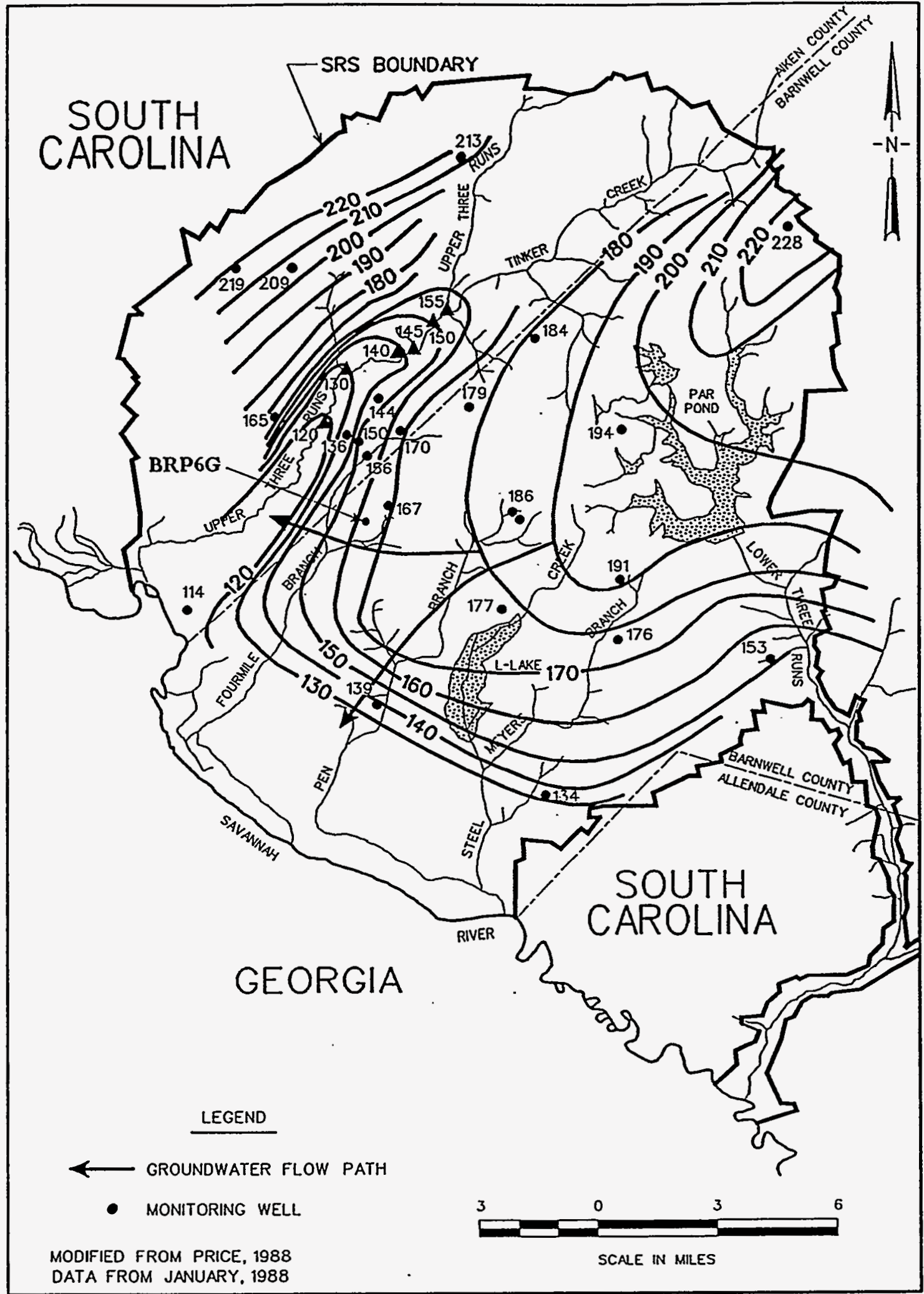

Figure 10. Regional Potentiometric Surface Map Aquifer Unit IIA 
System I-II at C Area ranges from approximately 0.0037 to $1.58 \mathrm{~cm} /$ day $(0.00012$ to $0.052 \mathrm{ft} /$ day $)$ or 1.46 to $578.51 \mathrm{~cm} /$ year ( 0.043 to $18.98 \mathrm{ft} /$ year).

Aquifer System I underlies Confining System I-II. Aquifer System I is divided into Aquifer Units IA and IB. Aquifer Unit IA includes the Pee Dee and upper Black Creek Formations. Figure 11 is a regional potentiometric map of Aquifer Unit IA. The map shows that groundwater flow in the aquifer is to the southwest toward the Savannah River.

Confining Unit IA-IB separates Aquifer Units IA and IB and includes the lower Black Creek Formation. Aquifer Unit IA is composed of the Middendorf.Formation. Figures 12 and 13 are regional potentiometric surface maps for the upper and lower parts of the Aquifer. Unit, respectively. These maps indicate that groundwater flow within the aquifer unit is to the southwest toward the Savannah River.

Aquifer System I supplies drinking water throughout the SRS. Two existing water supply wells in C Area, 905-90C and 905-91CC, are screened in the lower Pee Dee and upper Black Creek Formations of Aquifer System I. At C Area, four wells within the P-18 well cluster are screened in the Aquifer System I. Hydraulic heads measured in these screened zones during 1Q91 indicate the following:

- an upward vertical gradient of 0.019 from P-18A to P-18TD [Confining System I-II to Aquifer Unit IB]

- a downward vertical gradient of 0.003 from P-18TD to P-18TC [Upper Aquifer Unit IB to Lower Aquifer Unit IIB]

- an upward vertical gradient of 0.005 from P-18TC to P-18TB [Lower Aquifer Unit IB to Upper Aquifer Unit IA]

- An upward vertical gradient of 0.002 from P-18TB to P-18TA [Upper Aquifer Unit IA to Lower Aquifer IA]

In N Area, a reversal in the vertical hydraulic head between the overlying Aquifer Unit $\mathbb{I B}$ and the deeper Aquifer Unit IA is indicated at the P-18 well cluster. A reversal in hydraulic head also occurs between the overlying Confining System I-II and Aquifer Unit IIA. These head reversals inhibit vertical flow of groundwater from the Aquifer Unit IIA into Aquifer Unit IA, and from Aquifer Unit IB to Aquifer Unit IA, limiting the potential for downward migration of contaminants. 


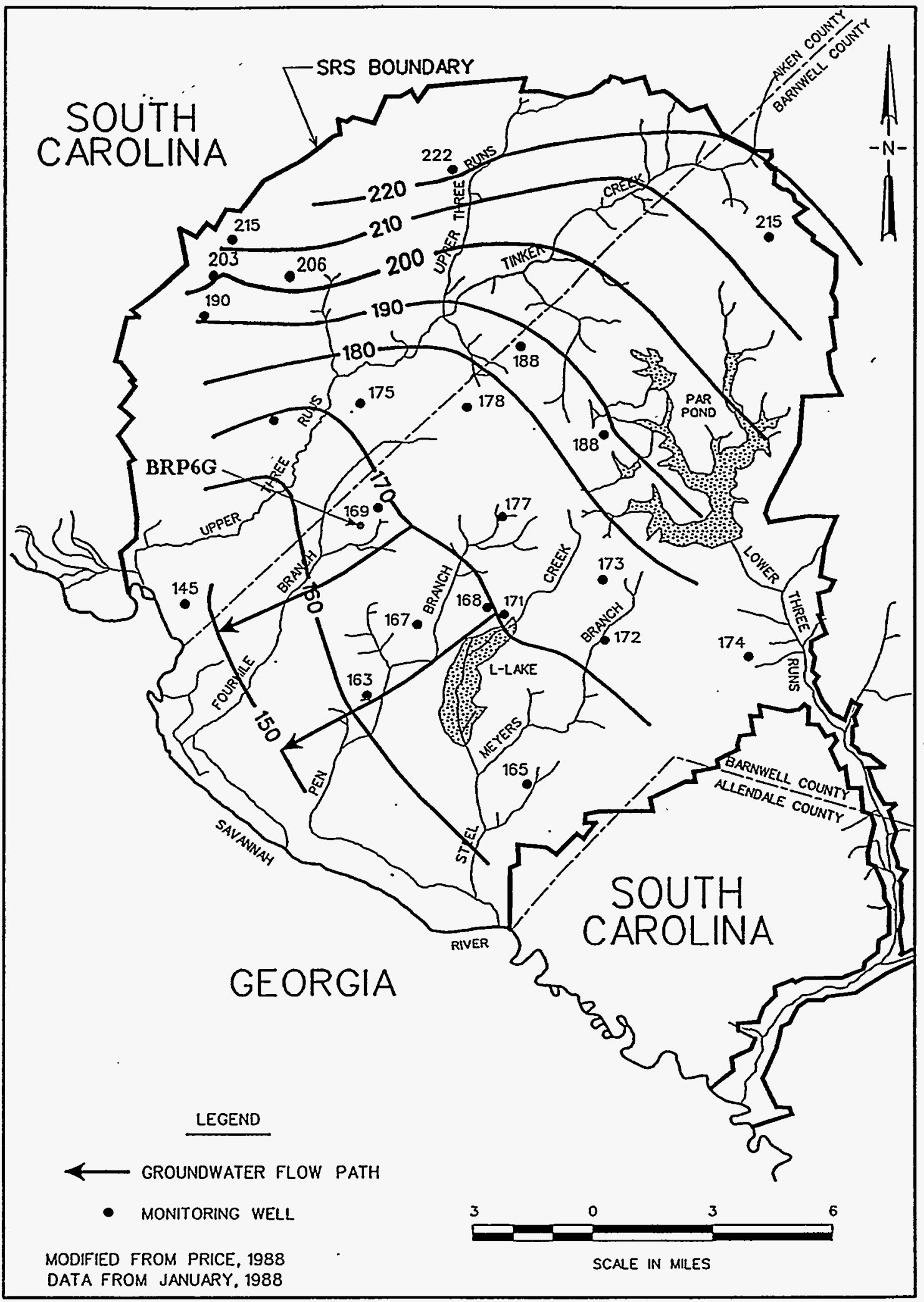

Figure 11. Regional Potentiometric Surface Map Aquifer Unit IB 


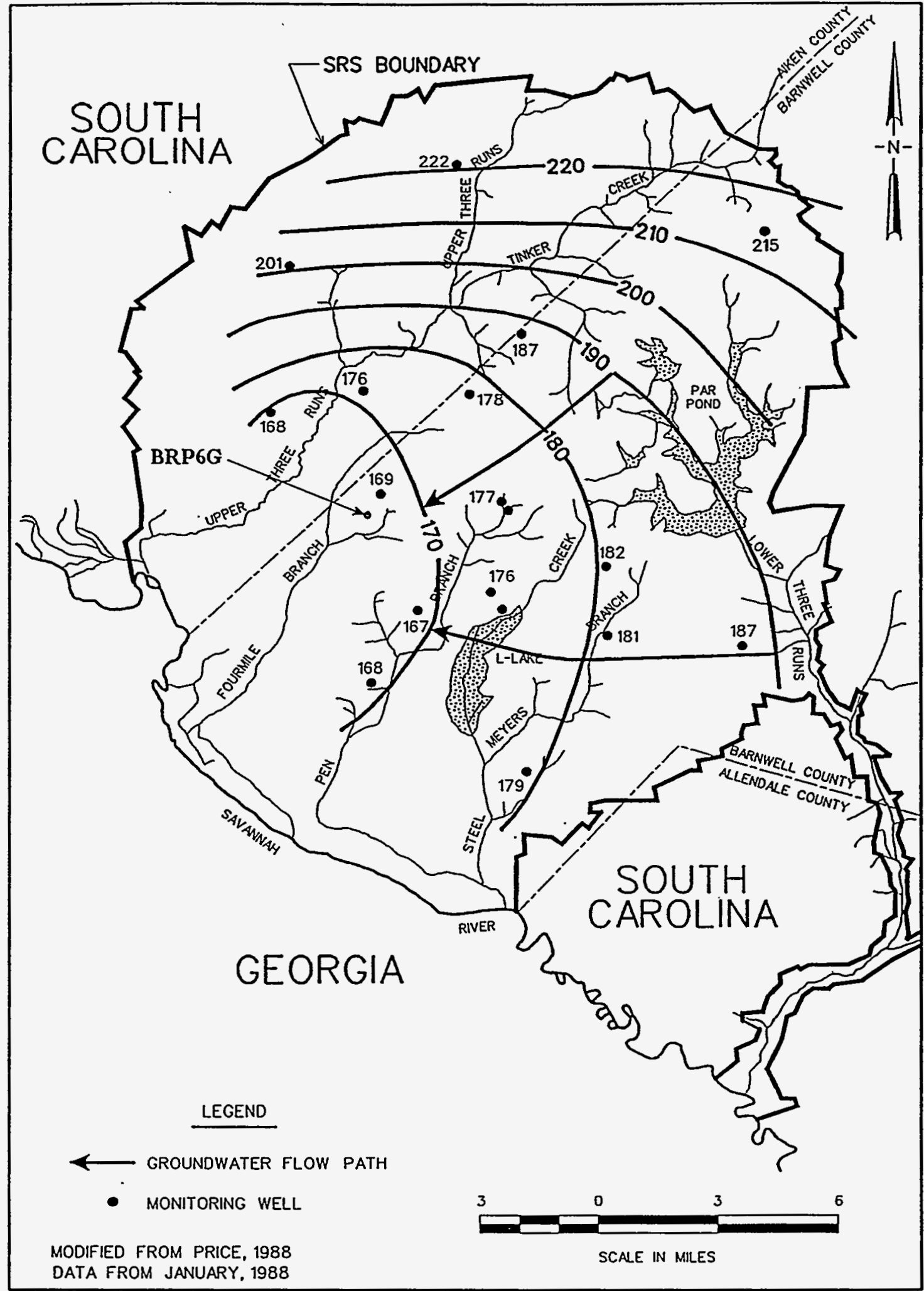

Figure 12. Regional Potentiometric Surface Map Upper Aquifer IA 


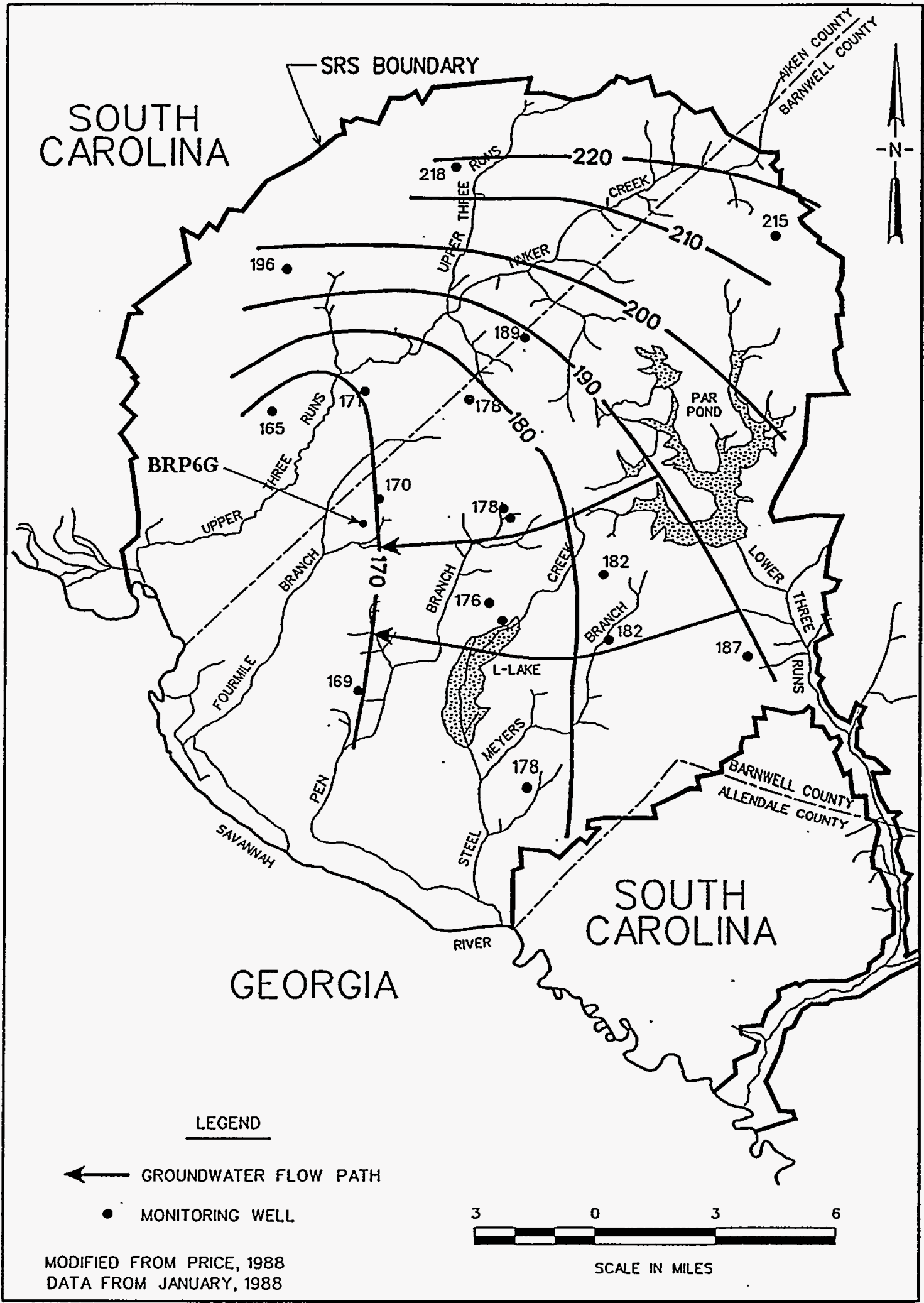

Figure 13. Regional Potentiometric Surface Map Lower Aquifer Unit IA 


\subsubsection{Local Hydrostratigraphy}

Numerous groundwater monitoring wells exist in C Area, including the CBR, HXB, and CSD well clusters. The location of Water Table monitoring wells in the vicinity of BRP6G is illustrated in Figure 14. All of the depicted wells are screened in the shallow Water Table Aquifer [approximately $15.2 \mathrm{~m}$ ( $50 \mathrm{ft}$ ) below land surface (bls)]. The "Tan Clay" (Confining Zone $\mathrm{WB}_{1}$ $\mathrm{IB}_{2}$ ) is not reported at well cluster $\mathrm{P}_{-18}$, and not evident at BRP6G also, which indicates that the shallow Water Table Aquifer and lower Water Table Aquifer (Aquifer Zone $\mathrm{IB}_{1}$ and $\mathrm{mB}_{2}$ ) are part of the Aquifer Unit IIB.

Water levels are recorded in each well on a quarterly basis. Using recently available groundwater data, the Water Table surface elevation was contoured (Figure 14). The map indicates that the direction of shallow groundwater flow is southward, with probable discharge into a tributary of Pen Branch ("Pen Branch Tributary") where the Water Table contours intersect the ground surface. Figure 15 is a potentiometric surface map of the Water Table (Aquifer Unit IIB) at the BRP6G using water level measurements (12/20/94) from the three temporary groundwater monitoring wells. In-situ measurements of hydraulic conductivity are not available for the Water Table Aquifer in $\mathrm{N}$ Area. 


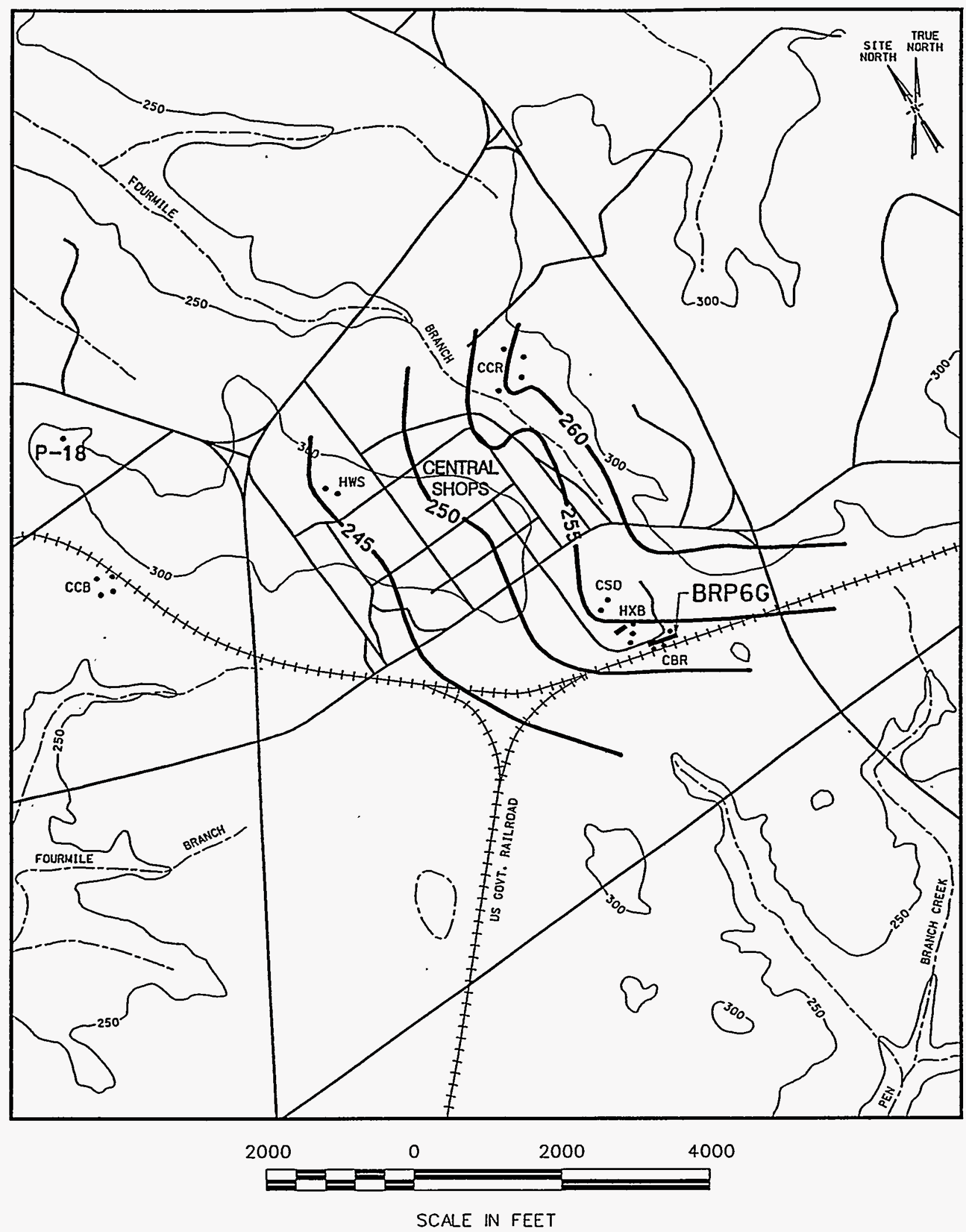

Figure 14. Potentiometric Surface of the Water Table (Aquifer Unit IIB) in the BRP6G Area 


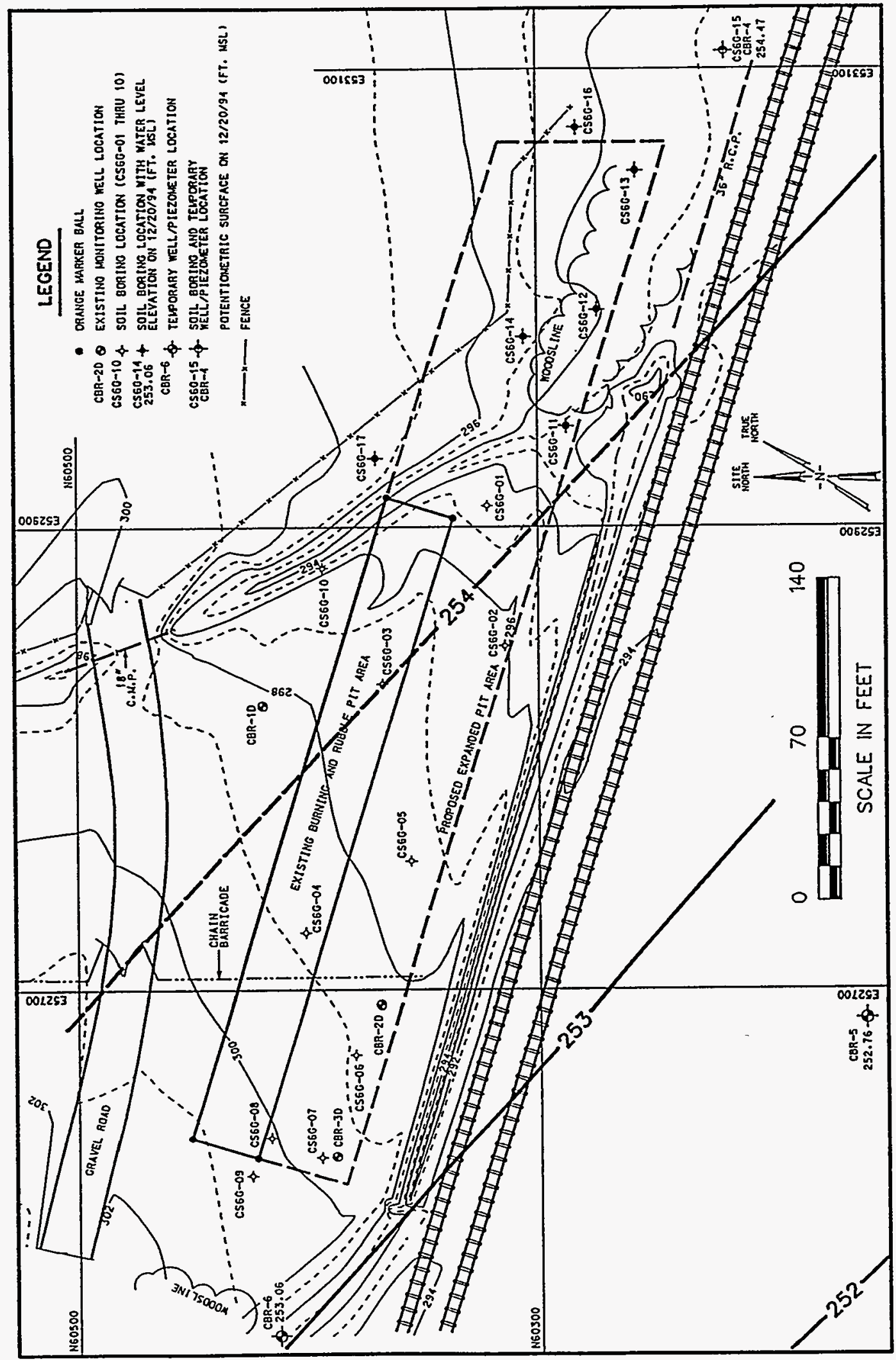

Figure 15. Potentiometric Surface of the Water Table (Aquifer Unit IIB) at the BRP6G 


\subsection{FIELD METHODS}

Field work at BRP6G was conducted between November 2 and December 30, 1994. Field activities included mud rotary drilling techniques for temporary groundwater monitoring well installation, well development, groundwater sampling, field permeability testing (slug testing), hollow stem auger drilling techniques with split-spoon sample collection, visual classification of soil, collection of surficial soil samples, and collection of surface water/sediment samples. Environmental Monitoring and Testing Corporation (EMTC) and Environmental Exploration, Inc. (EED) was subcontracted by WSRC to provide drilling services. All field activities were conducted in accordance with methods and procedures in the specified "Hydrogeologic Data Collection Methods, Procedures and Specifications", WSRC 3Q5 manual (WSRC, 1992), the RFI/RI Program Plan (1993a), and direction from the WSRC STR. Records for each temporary groundwater monitoring well include daily field logs and monitoring well installation reports. Appendix B presents the daily field logs for the project. Appendix $C$ presents the field records for the individual wells. Records for each soil boring include daily field logs, field geologic logs, and soil boring installation reports. Borehole records for each soil boring are combined and arranged according to soil boring number and are presented as Appendix D. Daily sign-in/sign-out logs and work zone entry/exit logs are included in Appendix E.

\subsection{Drilling and Geologic Sampling}

Mud rotary drilling methods were used during drilling and installation of the temporary groundwater monitoring wells. A total of three temporary groundwater monitoring wells were installed for this project: CBR-4, CBR-5, and CBR-6.

Name changes of the original staked locations for the temporary groundwater monitoring wells were necessary. The new names are more in keeping with standard reporting format and assisted in data management of the corresponding groundwater sampling locations.

\begin{tabular}{ll} 
Original Name & New Name \\
\cline { 2 - 2 } CBR-T1 & CBR-6 \\
CBR-T2 & CBR-5 \\
CBR-T3 & CBR-4
\end{tabular}

Bentonite-based drilling fluids (Quik-Gel ${ }^{\mathrm{TM}}$ ) were used only during the mud rotary drilling and well installations. Drilling was accomplished with a tri-cone drill bit. The drilling fluid parameters 
were carefully monitored and adjusted to properly clean the borehole, enhance stability and reduce drilling fluid loss. For groundwater monitoring well installations the boreholes were drilled to a nominal 20.3-cm (8-in.) diameter for the 5.1-cm (2-in.) diameter polyvinyl chloride (PVC) wells. See Table 1 for groundwater monitoring well installation information.

The field oversight used an organic vapor analyzer (OVA) or an $\mathrm{HNu}$ (trace gas analyzer) to monitor for the presence of volatile organics, which could originate from the borehole during drilling. Also, samples of the drill cuttings were collected for screening by WSRC HP to monitor for potential radioactive materials.

Hand auger and hollow stem auger drilling techniques were used throughout the project for soil sample collection. The first two soil samples 0.0 to $0.30 \mathrm{~m}(0.0$ to $1.0-\mathrm{ft}$ depth) and 0.30 to 0.61 $\mathrm{m}$ (1.0 to $2.0 \mathrm{ft})$ were collected at each sample location. A stainless steel 3-inch diameter hand auger was used to collect these samples and advance the borehole to the required sampling depth. Subsurface soil samples [deeper than $0.61 \mathrm{~m}(2.0 \mathrm{ft})$ ] were collected at each sample location using a truck-mounted auger drill rig. Hollow-stem augers advanced the borehole to the required sampling depth. Soil samples and lithologic samples were obtained by split-spoon from each soil boring. A 61-cm (24-in.) long, 5.1-cm (3-in.) outside diameter (O.D.) stainless steel split-spoon was lowered on drill rod through the hollow stem augers to the desired sampling depth. The splitspoon was hydraulically pushed or hammer driven into the formation. A total of 12 soil borings were installed for this project (CS6G-11. through CS6G-22). The split-spoons were opened in the field onto a clean plastic covered surface and immediately examined and described in the field by the technical oversight. Small portions of each sample were placed in Ziplock bags and later screened with either an OVA or a HNu for the presence of volatile organics. The soil was gently homogenized to ensure a representative composite sample over the depth of the sample interval. Then the soil was placed in appropriate laboratory supplied containers and stored in coolers onsite until prepared for offsite shipment.

Sample handling procedures and associated mobilization, demobilization, decontamination, and quality control procedures are specified in WSRC $3 Q 5$ and the RFI/RI Program Plan. To prevent and minimize cross-contamination between sampling locations, decontamination procedures were utilized. All down-hole drilling equipment (rig, hollow stem augers, etc.) were steam cleaned prior to use at the beginning of each soil boring. Then plastic sheeting was placed under the drill rig. Decontamination procedures for sampling equipment is detailed in Section 2.2.2. Soil cuttings from the augered boreholes were not removed from the waste unit area, but were either placed back 


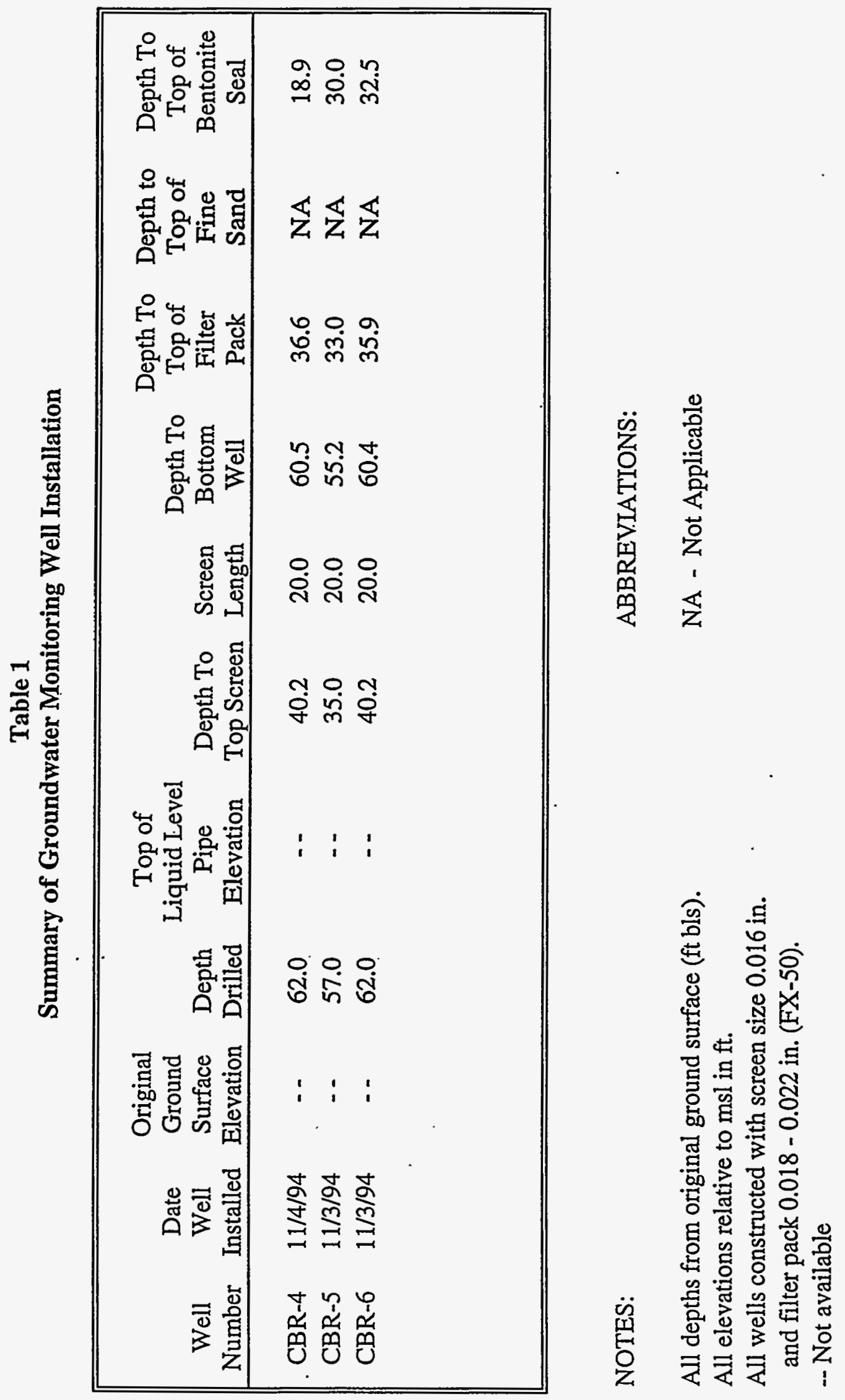


into the borehole in the soil boring abandonment process or dispersed about the unit area as specified in WSRC $3 Q 5$.

Detailed geologic logs were prepared by the RUST E\&I environmental engineer in the field. The field logs are included in Appendices $C$ and $D$ and arranged by borehole number. The grain-size classifications were based upon the modified Wentworth Scale in accordance with WSRC 3Q5.

Grain Size Classification

Pebbles

Granules (very fine pebbles)

Very Coarse Sand

Coarse Sand

Medium Sand

Fine Sand

Very Fine Sand

Silt

Clay
Diameter (mm)

$4-64$

$2-4$

$1-2$

$1 / 2-1$

$1 / 4-1 / 2$

$1 / 8-1 / 4$

$1 / 16-1 / 8$

$1 / 256-1 / 16$

$<1 / 256$

Size fraction percentages were based upon visual inspection and comparison with percentage charts. The degree of sorting present in the sample was based upon visual analysis. The following sorting classification system was adopted:

Well Sorted

Moderately Sorted

Poorly Sorted

Very Poorly Sorted
$90 \%$ of sample within 2 sand size classes $90 \%$ of sample within 3 sand size classes $90 \%$ of sample within 4 sand size classes $90 \%$ of sample within more than 4 size classes

Color descriptions were based upon comparisons with a standard Munsell ${ }^{T M}$ color chart. The features described on the logs consisted primarily of major sediment type, texture, color, carbonate zones, sedimentary structures, fossils, and accessory minerals. In general, grain sizes, percentages, color, roundness, and sphericity were described by comparison with charts. The soil was also visually classified according to the Unified Soil Classification System (USCS): 


\subsection{Temporary Groundwater Monitoring Well Design, Installation, and Sampling}

\subsubsection{Temporary Groundwater Monitoring Well Construction}

Three temporary groundwater monitoring wells were installed in the Water Table (CBR-4, CBR-5 and CBR-6). Well construction details for each monitoring well are presented in Appendix $\mathrm{C}$ and Table 1. The monitoring wells have been surveyed for location and elevation, and the information was included in an as-built report table provided to WSRC. The available as-built survey data for the groundwater monitoring wells are presented in Table 2.

All monitoring wells were constructed in accordance with specifications and procedures described in WSRC 3Q5 for monitoring wells, and the South Carolina Well Standards and Regulations, R.61-71 of the Code of Laws of South Carolina [South Carolina Department of Health and Environmental Control (SCDHEC), 1985]. The monitoring wells will be surveyed for location and elevation by WSRC, and the information will be included in an as-built report provided to WSRC. Screen intervals for the 5-cm (2-in.) diameter wells were selected after considering hydrogeologic data obtained from previous studies, reports and lithology.

The 5-cm (2-in.) diameter wells were constructed of PVC casing, machine slotted PVC screens with $0.041-\mathrm{cm}(0.016-\mathrm{in}$.) slot width, and a bottom plug either 6.1 or $9.1 \mathrm{~cm}(2.4$ or $3.6 \mathrm{in}$.) in length. Two stainless steel centralizers were installed as presented in Appendix B.

The filter pack consisted of 0.046 to $0.056-\mathrm{cm}(0.018$ to 0.022 -in.) uniform silica sand. The filter pack was installed from the bottom of the borehole to a minimum of $0.6 \mathrm{~m}(2 \mathrm{ft})$ above the screen through a tremie pipe placed adjacent to the well screen. A minimum of 0.9 to $1.5-\mathrm{m}$ ( 3 to $5-\mathrm{ft}$ ) thick bentonite pellet seal was installed above the filter pack. After at least 2 hours of hydration time, a cement/bentonite grout cap was installed through a tremie pipe lowered to just above the . bentonite seal. The minimum allowable cement weight was $1.58 \mathrm{~g} / \mathrm{cm}^{3}$ (13.2 lbs/gal). Any variations in well construction is presented in Appendix C.

A strong effort was made to minimize the potential of introducing contamination into the subsurface or the local environment during drilling operations. This effort was made so that the results of water quality sampling would be representative of actual groundwater conditions. All well construction materials were secured or wrapped in plastic for storage at the drill site. The 
Table 2

Coordinates and Elevation Details

\begin{tabular}{|c|c|c|c|c|}
\hline Well Number & Northing & Easting & $\begin{array}{l}\text { Top of Casing } \\
\text { Elevation* }\end{array}$ & $\overline{\text { Pad Elevation* }}$ \\
\hline$\overline{\overline{C B R}-4}$ & $\begin{array}{c}60218.24 \\
33.24560867\end{array}$ & $\begin{array}{c}53107.95 \\
81.64393628\end{array}$ & 295.84 & $\overline{\overline{293.4}}$ \\
\hline CBR-5 & $\begin{array}{c}60158.39 \\
33.24479117\end{array}$ & $\begin{array}{c}52687.98 \\
81.64492561\end{array}$ & 295.89 & 293.3 \\
\hline CBR-6 & $\begin{array}{c}60413.28 \\
33.24512914\end{array}$ & $\begin{array}{c}52549.53 \\
81.64578486\end{array}$ & 303.91 & 301.4 \\
\hline Soil Boring & $\overline{\text { Northing }}$ & $\overline{\text { Easting }}$ & \multicolumn{2}{|c|}{ Ground Surface Elevation* } \\
\hline$\overline{C \text { CS6G-11 }}$ & $\begin{array}{c}60292.81 \\
33.24547969\end{array}$ & $\begin{array}{c}52927.78 \\
81.64455530\end{array}$ & \multicolumn{2}{|c|}{293.0} \\
\hline CS6G-12 & $\begin{array}{c}60278.56 \\
33.24556414\end{array}$ & $\begin{array}{c}52998.90 \\
81.64434044\end{array}$ & \multicolumn{2}{|c|}{294.2} \\
\hline CS6G-13 & $\begin{array}{c}60275.55 \\
33.24564386\end{array}$ & $\begin{array}{c}53051.84 \\
81.64419522\end{array}$ & \multicolumn{2}{|c|}{293.9} \\
\hline CS6G-14 & $\begin{array}{c}60304.73 \\
33.24558158\end{array}$ & $\begin{array}{c}52974.07 \\
81.64445658\end{array}$ & \multicolumn{2}{|c|}{295.4} \\
\hline CS6G-15 & $\begin{array}{c}60257.33 \\
33.24550322\end{array}$ & $\begin{array}{c}52990.29 \\
81.64432189\end{array}$ & \multicolumn{2}{|c|}{293.4} \\
\hline CS6G-16 & $\begin{array}{c}60265.53 \\
33.24572022\end{array}$ & $\begin{array}{c}53112.24 \\
81.64401678\end{array}$ & \multicolumn{2}{|c|}{293.4} \\
\hline CS6G-17 & $\begin{array}{c}60334.64 \\
33.24560667\end{array}$ & $\begin{array}{c}52948.92 \\
81.64458086\end{array}$ & \multicolumn{2}{|c|}{296.6} \\
\hline CS6G-18 & $\begin{array}{c}60393.28 \\
33.24567778\end{array}$ & $\begin{array}{c}52912.99 \\
81.64478928\end{array}$ & \multicolumn{2}{|c|}{298.4} \\
\hline CS6G-19 & $\begin{array}{c}59918.47 \\
33.24551744\end{array}$ & $\begin{array}{c}53458.61 \\
81.64243128\end{array}$ & \multicolumn{2}{|c|}{293.3} \\
\hline CS6G-20 & $\begin{array}{c}60041.66 \\
33.24455736 \\
\end{array}$ & $\begin{array}{c}52702.91 \\
81.64465972\end{array}$ & \multicolumn{2}{|c|}{290.1} \\
\hline
\end{tabular}


Table 2 (continued)

Coordinates and Elevation Details

\begin{tabular}{|c|c|c|c|}
\hline Soil Boring & Northing & $\overline{\text { Easting }}$ & Ground Surface Elevation* \\
\hline CS6G-21 & $\begin{array}{c}60468.84 \\
33.24428697\end{array}$ & $\begin{array}{c}51957.93 \\
81.64744997\end{array}$ & $\overline{299.9}$ \\
\hline CS6G-22 & $\begin{array}{c}60315.96 \\
33.24553683\end{array}$ & $\begin{array}{c}52931.42 \\
81.64459067\end{array}$ & 292.4 \\
\hline CS6G-23 & $\begin{array}{c}60284.13 \\
33.24531669\end{array}$ & $\begin{array}{c}52839.65 \\
81.64477044\end{array}$ & 291.0 \\
\hline CS6G-24 & $\begin{array}{c}60245.76 \\
33.24544075\end{array}$ & $\begin{array}{c}52967.73 \\
81.64435880\end{array}$ & 289.2 \\
\hline CS6G-25 & $\begin{array}{c}60192.74 \\
33.24563730\end{array}$ & $\begin{array}{c}53160.10 \\
81.64374947\end{array}$ & 288.1 \\
\hline CS6G-26 & $\begin{array}{c}60391.23 \\
33.24498311\end{array}$ & $\begin{array}{c}52489.87 \\
81.64589911\end{array}$ & 293.1 \\
\hline CS6G-27 & $\begin{array}{c}60408.66 \\
33.24491783\end{array}$ & $\begin{array}{c}52426.24 \\
81.64610044\end{array}$ & 293.7 \\
\hline CS6G-28 & $\begin{array}{c}60428.72 \\
33.24486497\end{array}$ & $\begin{array}{c}52366.66 \\
81.64629622\end{array}$ & 293.6 \\
\hline CS6G-29 & $\begin{array}{c}59772.66 \\
33.24398319\end{array}$ & $\begin{array}{c}52715.75 \\
81.64410372\end{array}$ & 279.8 \\
\hline CS6G-30 & $\begin{array}{c}59934.33 \\
33.24472905\end{array}$ & $\begin{array}{c}52953.74 \\
81.64379108\end{array}$ & 282.2 \\
\hline CS6G-31 & $\begin{array}{c}5996.22 \\
33.24504417\end{array}$ & $\begin{array}{c}53062.99 \\
81.64362364\end{array}$ & 284.4 \\
\hline CS6G-32 & $\begin{array}{c}60071.58 \\
33.24532817\end{array}$ & $\begin{array}{c}53134.87 \\
81.64358072\end{array}$ & 285.7 \\
\hline CS6G-33 & $\begin{array}{c}60114.87 \\
33.24549680\end{array}$ & $\begin{array}{c}53179.56 \\
81.64354711\end{array}$ & 286.4 \\
\hline
\end{tabular}

* Elevations relative to Mean Sea Level.

LAT indicates latitude in decimal degrees. LON indicates longitude in decimal degrees. 
drilling and downhole equipment, including drilling and development tools, bailers, pumps, well casings, and well screens were steam cleaned just prior to use or installation and between well sites to minimize the chances of cross-contamination. At each site, plastic sheeting was placed under the drilling rig to contain any fluid leaks from service trucks or the drill rig. Any oil or hydraulic leaks present on the plastic sheet were absorbed with dry bentonite powder and disposed of by WSRC drilling subcontract personnel.

\subsubsection{Well Development}

Following subsurface completion, each well was developed under guidelines outlined in WSRC 3Q5 and under the direction of WSRC personnel. Well development records included such information as $\mathrm{pH}$, specific conductance, and volume of water-removed from the wells. Well development reports were prepared by the drilling companies and submitted to WSRC Environmental Protection Department Groundwater Monitoring Group. Well development results are summarized in Table 3 of this report. Appendix F includes well development records from EMTC.

Initially, each well was developed by bailing slowly. This procedure allows the filter-sand to settle around the screen properly, while purging heavy drilling mud from the well casing, and initiating breakdown of the mud cake formed during rotary drilling operations. The wells were bailed as soon as possible after completion in order to facilitate the initial breakdown of the mud cake. As the development process progressed, the wells were surged by rapidly raising and lowering the bailer. The muddy water was then bailed.

If the groundwater monitoring wells required additional development, a submersible pump outfitted with a surge block was used to surge, or swab discreet areas of the screened zone and remove large volumes of fluid. This surge block was made of a rigid rubber stopper attached to the tremie pipe a few feet above the submersible pump. It was only slightly smaller in diameter than the inside diameter of the well being developed, so that the tremie could be raised and lowered to swab an area of the screen. The surge block would push water out of the screen zone as the tremie and pump were lowered and pull water into the screen zone as they were lifted. When the $\mathrm{pH}$ and conductivity of the well had stabilized, the submersible pump was removed from the well. Both of these methods were utilized in the development of the groundwater monitoring wells (see Table 3). 


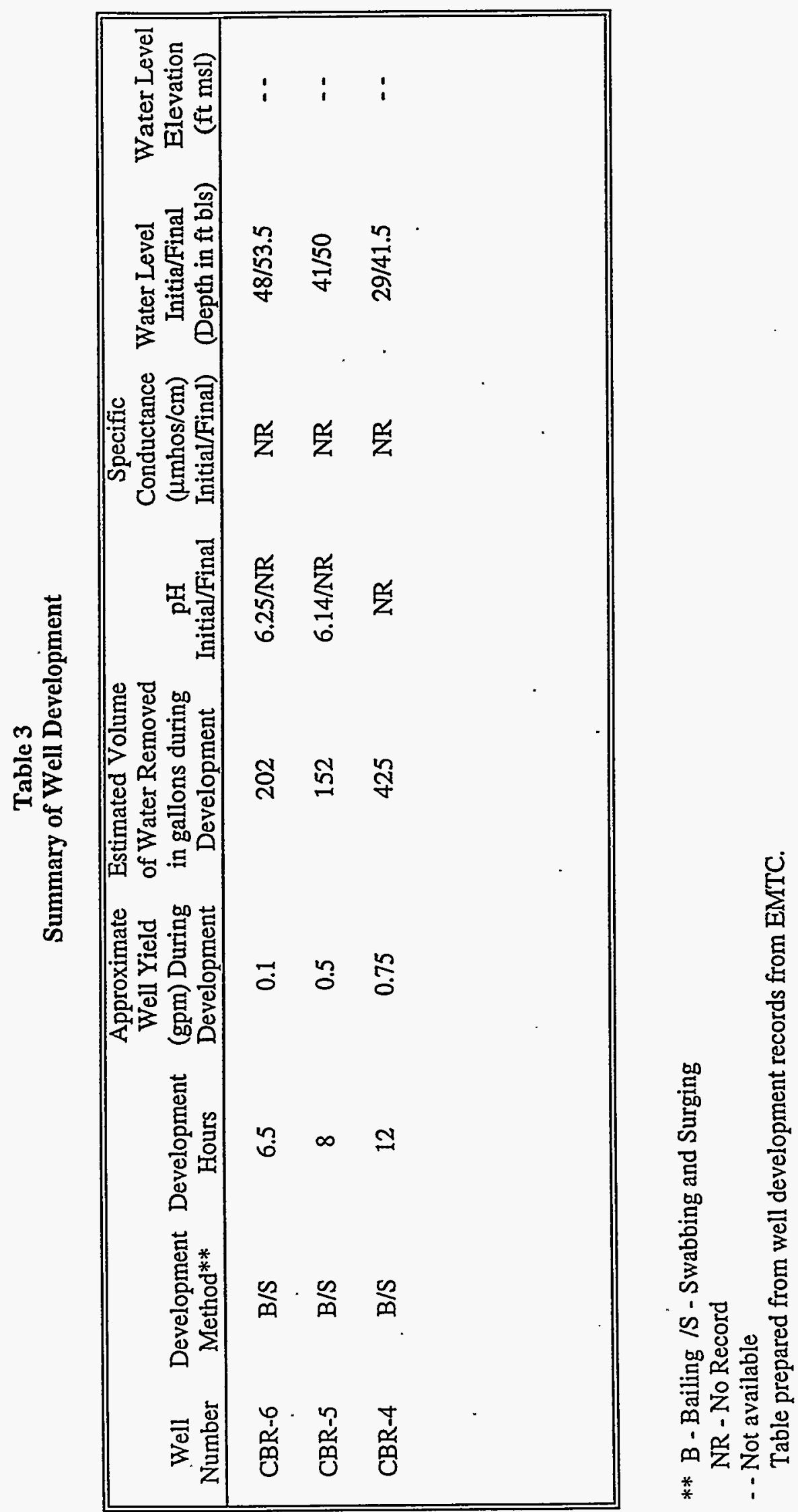




\subsubsection{Groundwater Sampling}

Groundwater samples were collected in two different sampling phases from the three temporary groundwater monitoring wells (CBR-4, CBR-5, and CBR-6) on December 5 and December 28, 1994. The Addendum to Chapter 4 of the RFI/RI Work Plan for the Central Shops Burning/Rubble Pit, 631-6G lists the sampling analytes (see Appendix A). All wells were sampled in accordance with WSRC 3Q5. A summary table of the sampling data is presented in Appendix G. The analytical results for this groundwater sampling are not yet available and will not be presented in this report.

\subsubsection{Field Permeability Testing}

After well development was complete, slug tests (both rising and falling head) were performed on each monitoring well to estimate the hydraulic conductivity $(\mathrm{K})$ of the screened formations. The data were analyzed using the Bouwer and Rice (1976) method (Aqtesolv Aquifer Test Solver, version 1.1, Aqtesolv Test Design and Analysis Computer Software by Geraghty \& Miller, Inc., Environmental Services Modeling group).

\section{Test Procedure}

Slug tests require the instantaneous displacement of a volume of water within a well or piezometer. . A field testing system was used which could be easily set up with a PVC slug (cylinder). The slug was a cylinder constructed of nominal PVC pipe. The cylinder or slug was $2.54 \mathrm{~cm}(1 \mathrm{in}$.) in diameter. The cylinder had caps secured on both ends and one end cap was fitted with a lifting hook. The pipe was filled with clean water to serve as ballast.

Falling head test data were reported for each of the monitoring wells. The falling head tests were performed by tying a nylon rope to the lifting hook of the cylinder, submerging the cylinder, and measuring the fall in head in the well casing as the water level returned to static conditions. A pressure transducer linked to an electronic data recorder was used to record the fall in head.

A rising head test was performed once the falling head test reached near static conditions. The rising head test measures the rise in head or the recharge of water after the submerged cylinder had been quickly removed from the well or piezometer. 


\section{Data Analysis}

The Bouwer and Rice Method (1976) was used in this program to analyze the slug test data. It is applicable to fully or partially-penetrating wells in confined and unconfined aquifers and assumes negligible drawdown of the Water Table around the well and no flow above the Water Table. (Aqtesolv Aquifer Test Solver, version 1.1)

The Bouwer and Rice equation for estimating hydraulic conductivity is:

$$
K=\frac{r_{c}^{2} \ln \left(R_{c} / r_{w}\right)}{2 L} \times \frac{1}{t} \times \ln \frac{y_{0}}{y_{t}}
$$

where, $\quad \mathrm{R}_{e}=$ effective radial distance over which the head difference is dissipated $r_{C}=\quad$ radius of the section where the water level is rising. If the water level is rising within the screen,

$$
\mathrm{rc}=\sqrt{\mathrm{r}_{\mathrm{c}}^{2}+\mathrm{n}\left(\mathrm{r}_{\mathrm{w}}^{2}-\mathrm{r}_{\mathrm{c}}^{2}\right)}
$$

$$
\begin{aligned}
& r_{W}=\quad \text { radial distance between well center and undisturbed aquifer }\left(r_{c}\right. \text { plus } \\
& \text { thickness of gravel envelope or developed zone outside casing) } \\
& \mathrm{L}=\text { height of perforated, screened, encased or otherwise open section of well } \\
& \text { through which groundwater enters } \\
& y=\quad \text { the level of water in the well above or below the Water Table } \\
& \mathrm{yo}_{\mathrm{o}}=\mathrm{y} \text { at time zero } \\
& \mathrm{yt}_{\mathrm{t}}=\quad \mathrm{y} \text { at time } \mathrm{t} \\
& \mathrm{t}=\quad \text { time since yo }
\end{aligned}
$$

An empirical equation is used that relates $R_{e}$ to the geometry and boundary conditions of the system:

$$
\ln \frac{R_{c}}{r_{w}}=\frac{1}{\frac{1.1}{\ln \left(H / r_{w}\right)}+\frac{A+B \ln \left[(D-H) / r_{w}\right]}{\left(L / r_{w}\right)}}
$$


where $\quad H=\quad$ vertical distance from the Water Table to the base of $L$

$D=\quad$ the aquifer thickness

$\mathrm{A}, \mathrm{B}=$ dimensionless parameters found by comparing their relationship to $L / r_{\mathrm{W}}$ on a graph of curves provided by Bouwer and Rice (1976).

The observed values of $y$ are plotted against $t$ on semilogarithmic paper ( $y$ on the log scale).

\section{$\underline{\text { Results }}$}

Hydraulic conductivity estimates for temporary wells CBR-04 through CBR-06 ranged from $2.95 \mathrm{E}-5 \mathrm{~cm} / \mathrm{sec}(9.68 \mathrm{E}-7 \mathrm{ft} / \mathrm{sec})$ to $4.2 \mathrm{E}-4 \mathrm{~cm} / \mathrm{sec} \cdot(1.378 \mathrm{E}-5 \mathrm{ft} / \mathrm{sec})$ and averaged $1.88 \mathrm{E}-4 \mathrm{~cm} / \mathrm{sec}$ $(6.18 \mathrm{E}-6 \mathrm{ft} / \mathrm{sec})$. The hydraulic conductivity estimates for all the wells slug tested (rising and falling head) are presented in Table 4. Data plots of the slug tests are included in Appendix H. These hydraulic conductivity estimates were fairly typical for the lithologies encountered.

\subsection{Soil Sampling}

\subsubsection{Soil Sample Locations and Intervals}

The objectives of the soil sampling investigation are (1) to confirm the results of the previous soil sampling (2) to define the pit boundaries in light of the new data provided by historical aerial photographs, and (3) to characterize any potential sources of contamination at the BRP6G and to determine the location of these sources. The Addendum to Chapter 4 of the RFI/RI Work Plan for the Central Shops Burning/Rubble Pit, 631-6G, details the changes to the work plan unit assessment activities and lists the sampling interval and analytes (see Appendix $\cdot \mathrm{A}$ ).

Soil boring locations are illustrated in Figures 3 and 4. See Table 2 for coordinates and ground surface elevations. Borings CS6G-11 and CS6G-14 were expected to be located within the proposed expanded pit/unit area. Results from these borings will provide information regarding the presence or absence of contaminants within the area designated by the historical aerial photographs as the BRP6G. 
Table 4

Groundwater Monitoring Well

Hydraulic Conductivity Estimates *

\begin{tabular}{|c|c|c|c|}
\hline & \multicolumn{3}{|c|}{ Hydraulic Conductivity $(\mathrm{K})$} \\
\hline Well No. & $(\mathrm{ft} / \mathrm{sec})$ & (ft/day) & $(\mathrm{cm} / \mathrm{sec})$ \\
\hline CBR -40 & $3.19 E-6$ & 0.276 & $9.72 \mathrm{E}-5$ \\
\hline CBR-5 & $8.48 \mathrm{E}-6$ & 0.733 & $2.59 \mathrm{E}-4$ \\
\hline CBR-6 & $6.78 \mathrm{E}-6$ & 0.587 & $2.068 \mathrm{E}-4$ \\
\hline & & \multicolumn{2}{|c|}{ Average } \\
\hline $\begin{array}{l}\text { Hydrostratigraphic } \\
\text { Unit/Zone }\end{array}$ & $\begin{array}{l}\text { Range } \\
\mathrm{ft} / \mathrm{sec}\end{array}$ & $\mathrm{ft} /$ day & $\mathrm{cm} / \mathrm{sec}$ \\
\hline Aquifer Zone $\mathrm{IBB}_{2}$ (Water Table) & $\begin{array}{l}9.68 \mathrm{E}-7 \\
\text { to } 1.38 \mathrm{E}-5\end{array}$ & 0.53 & $1.88 \mathrm{E}-4$ \\
\hline
\end{tabular}

* Based on Field Permeability Testing (Slug Tests)

$\checkmark$ The Falling Head slug test for CBR-4 was not acceptable; therefore the $\mathrm{K}$ presented is for the Rising Head slug test only. 
Borings CS6G-15, CS6G-16, and CS6G-17 are located outside the proposed expanded unit/area. Results from these borings will provide information regarding the presence or absence of contaminants outside of the area designated as the BRP6G by the historical aerial photographs.

Background soil sample locations (CS6G-18 through CS6G-22) were selected in cooperation with a soil taxonomist at the time the sampling was conducted (Figure 4). Selected locations are considered beyond the area that potentially may have been impacted from waste disposal activities at the unit. In addition, six surficial $0-0.3 \mathrm{~m}(0-1 \mathrm{ft})$ soil samples were obtained within the ditch located along the railroad, south of the pit. Three of the samples.were selected.within the ditch, upgradient and beyond the area of potential impact by the unit. The remaining three samples were collected within the ditch, downgradient from the pit.

The first sample was collected at the surface to $0.3 \mathrm{~m} \mathrm{(1.0} \mathrm{ft)} \mathrm{bls.} \mathrm{The} \mathrm{second} \mathrm{sample} \mathrm{was}$ collected from $0.3 \mathrm{~m}$ to $0.6 \mathrm{~m}$ ( 1.0 to $2.0 \mathrm{ft}$ ) bls. Samples were then collected continuously at 0.6 $\mathrm{m}(2.0 \mathrm{ft})$ intervals until two consecutive samples screened clean for volatile organics below the bottom of the pit (Figure 16). The bottom of the pit was designated as the interface from observed burn material and residual soil. The Addendum to Chapter 4 of the RFI/RI Work Plan for the Central Shops Burning/Rubble Pit, 631-6G (Appendix A) designates the analyses to be performed at each sampling interval. The list of possible analytes include Target Compound List/Target Analyte List (TCLTAL) with Tentatively Identified Compounds (Library Scan) (TIC), Dioxins/Furans, Radiological Indicators, Gas Chromatograph/Mass Spectrophotometer (GC/MS) volatile organic compounds (VOCs), RCRA metals, and TCL VOCs only.

A split of each soil sample was screened in the field for organic vapors using an OVA or an $\mathrm{HNu}$, as outlined in WSRC 3Q5 and the RFI/RI Program Plan. As negotiated with SCDHEC, sampling continued when VOCs field screening indicated contamination in either of the last two samples.

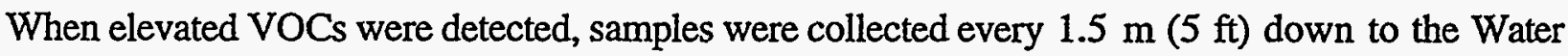
Table or until field screening indicated no contamination in two consecutive samples, whichever came first (see Figure 16 under the heading "anomalies").

In accordance with WSRC $3 Q 5$ and the RFI/RI Program Plan, field quality control samples were collected during the soils investigation. Trip blanks were added to the work plan and were submitted for TCL VOC analytes. Aqueous trip blanks were provided by the laboratory at the 


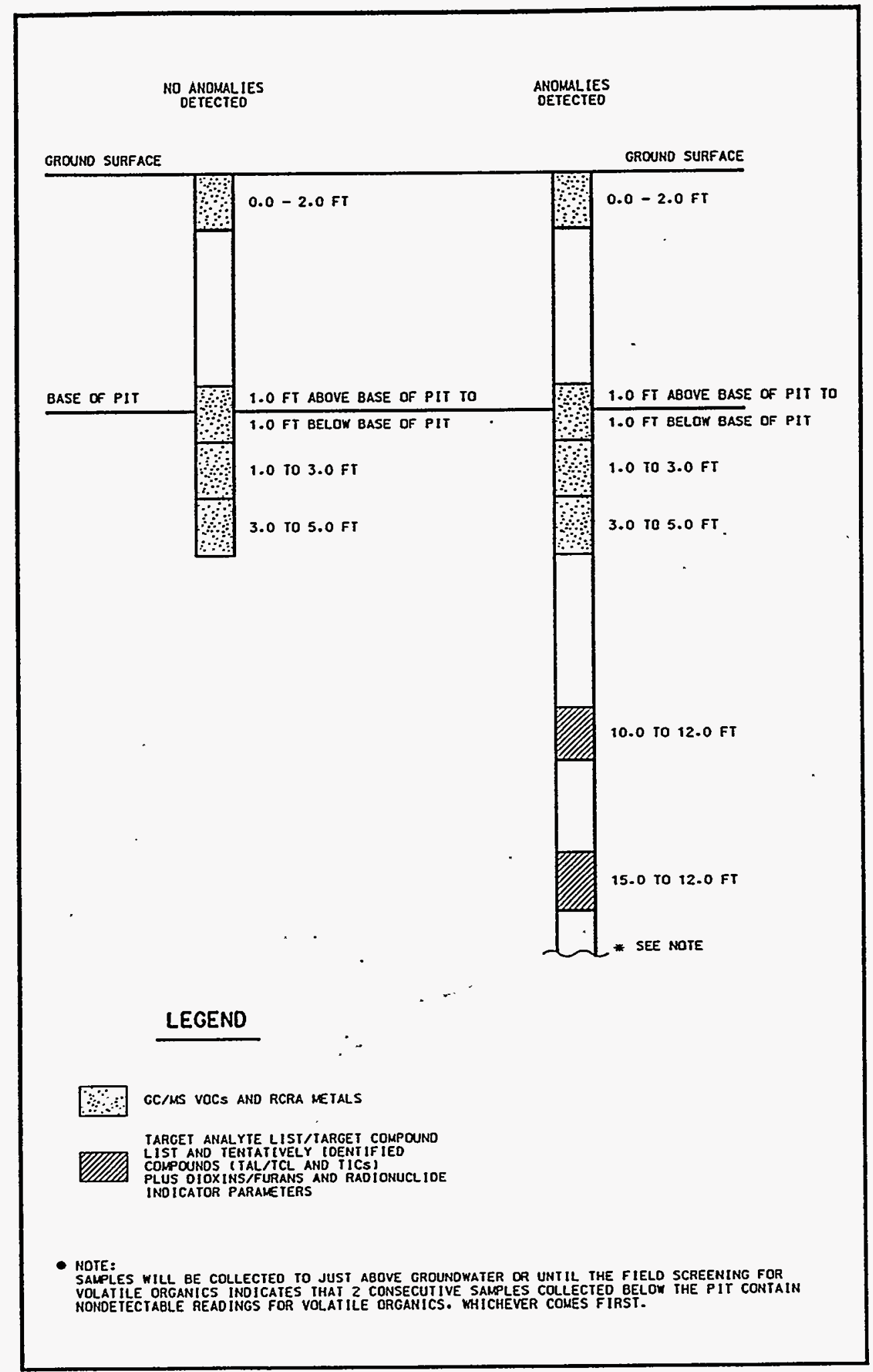

Figure 16. . Soil Sampling Depths and Analytical Parameters 
frequency of one trip blank per cooler. All samples for VOC analysis were placed in the same cooler for each day's sample shipment.

\subsubsection{Soil Sampling Procedures}

As previously described in Section 2.1, soil was collected from each soil boring using a stainless steel hand auger or a split-spoon. Caution was taken to ensure minimum loss of volatiles by keeping the split-spoon closed until the soil sample was collected. Scrapings were taken down the length of the split-spoon sample and placed in air tight plastic bags for volatile screening with an OVA. Scrapings were also taken along the length of the split-spoon to fill the VOC containers for laboratory analysis. A small section of the sample was set aside for descriptive purposes (see Section 2.1) and the remainder of the sample was carefully homogenized and the remaining laboratory containers were filled. Sample container, preservation, storage, and holding time requirements are specified in the Central Shops Burning/Rubble Pit 631-6G, Revision 2, RFI/RI Work Plan. All disposable sampling supplies and materials were removed from the waste unit areas and disposed of in accordance with current WSRC procedures.

Preparation for sample collection included pre-printed chain-of-custody (COC) forms, pre-printed labels with bar code identification system, and receipt of required laboratory containers (including laboratory trip blanks). These tasks were handled by EMS. Sample container and documentation kits were then gathered (containers for each interval at each sampling location), and the bar code identification system was put into effect via the accompanying COC forms. There was a bar code printed for the container and corresponding COC form and for the EPD/EMS Soil Sample Logbooks. When the sample interval had been determined in the field, the final phase of the bar code identification system was enacted. The final bar code sticker was placed in the EPD/EMS Soil Sample Logbook under the sample identification (ID) number for that specific sampled interval in that specific soil boring [i.e., sample $\mathrm{DD} 101876$ is the sample collected from 0.00 to $0.61 \mathrm{~m}$ ( 0.00 to $2.00 \mathrm{ft}$ ) bls, which is the first sampling interval in soil boring CS6G-11]. The time, date, sampler, sample type, sample matrix, Munsell ${ }^{\mathrm{TM}}$ color, lithologic description, soil wetness, associated samples, and unified soil classification are also recorded in the EPD/EMS Soil Sample Logbook.

Preparation for soil sample collection includes decontamination of the soil sampling equipment. Sampling equipment (split-spoons, stainless steel bowls, spatulas, etc.) were decontaminated prior to use in accordance with the following cleaning procedures: 
- Sampling equipment or materials not used immediately after decontamination were placed on a plastic sheet and secured to avoid potential contamination.

- Clean with deionized water and phosphate-free laboratory detergent, (Alconox) using a brush if necessary to remove particulate matter and surface films.

- $\quad$ Rinse thoroughly with deionized water.

- $\quad$ Rinse with pesticide-grade isopropanol solvent.

- . Rinse thoroughly with deionized water, and allow to air dry before use.

Wrap sampling equipment completely with aluminum foil, shiny side out, to prevent contamination if equipment is to be stored or transported.

Clean, disposable gloves will be worn while handling sampling equipment or downhole tools during decontamination. Deionized water will be stored in plastic containers and applied from plastic pump sprayers or decanted directly from the storage container. Storage of isopropanol at SRS requires storage in a non-flammable, steel container marked flammable.

\subsubsection{Soil Sample Results}

Soil borings were installed according to the planned order and consisted of: CS6G-11, CS6G-12, CS6G-13, CS6G-14, CS6G-15, CS6G-16, CS6G-17, CS6G-18, CS6G-19, and CS6G-20, CS6G-21 and CS6G-22. The first borings drilled were those considered most likely to contain elevated contaminant values. In addition, this sequence allowed definition of the pit depths and boundaries in the borings that were located within the pit areas (see Table 5). The depths to pit bottom were used to determine sample depths in the four borings located outside the pit (CS6G-11, CS6G-15, CS6G-16, and CS6G-17) and the background borings (CS6G-18 through CS6G-21).

During soil boring installation, an OVA or HNu was used to screen for the presence of volatile organics to determine the vertical extent for sampling. OVA readings were below detection limits for all borings inside the pit boundaries except for boring CBR-14 with OVA readings as follows:

BORING CS6G-14

\begin{tabular}{cc} 
Depth Below Ground Surface (ft) & OVA Reading(ppm) \\
\cline { 2 - 2 } $0-1$ & 15 \\
$1-2$ & 20 \\
$2-4$ & 3 \\
$4-6$ & 10 \\
$6-8$ & 12 \\
$8-10$ & 0 \\
$13-15$ & 0
\end{tabular}


Table 5

Summary of Soil, Surface Water/Sediment Sampling

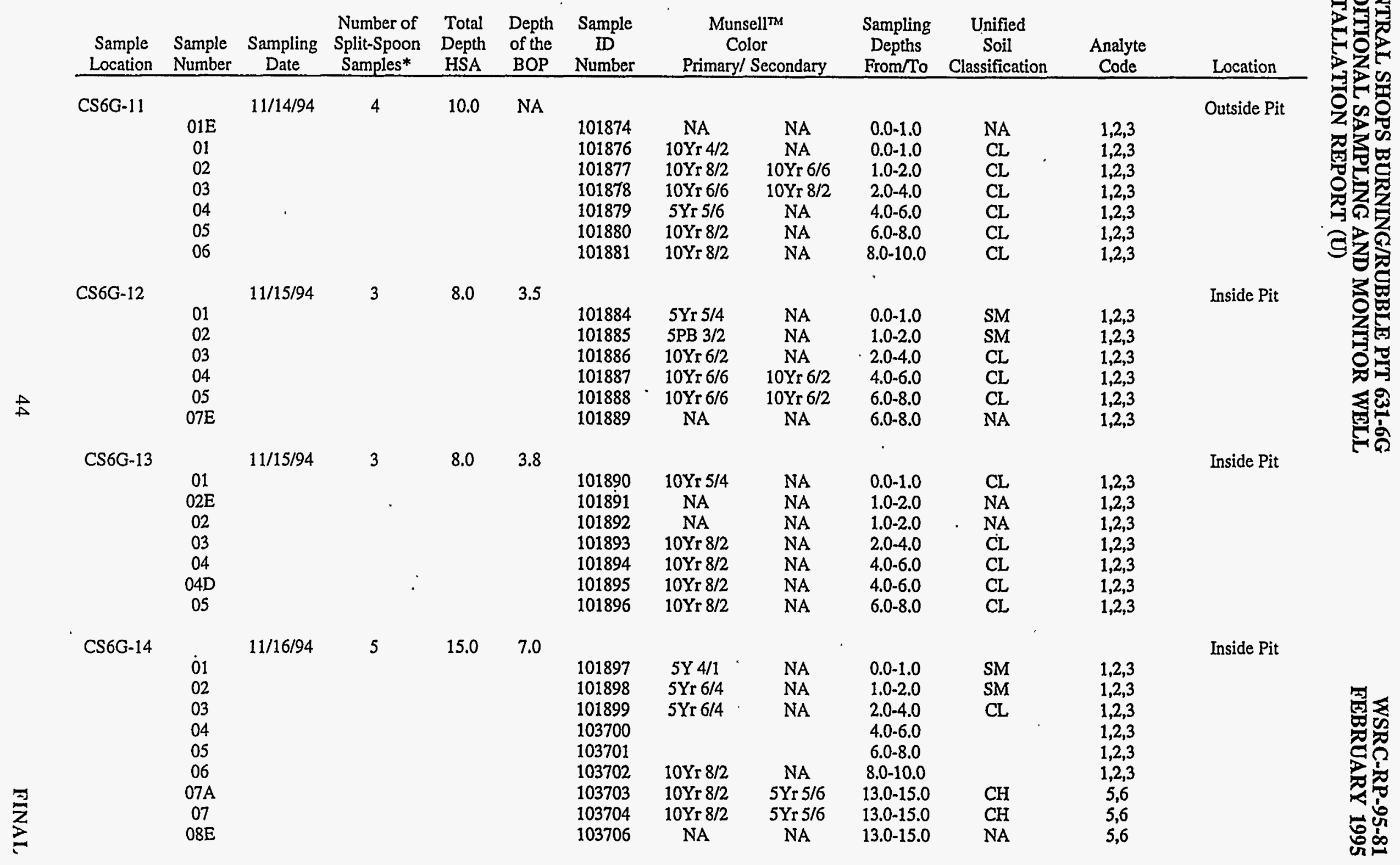


Table 5 (continued)

Summary of Soil, Surface Water/Sediment Sampling

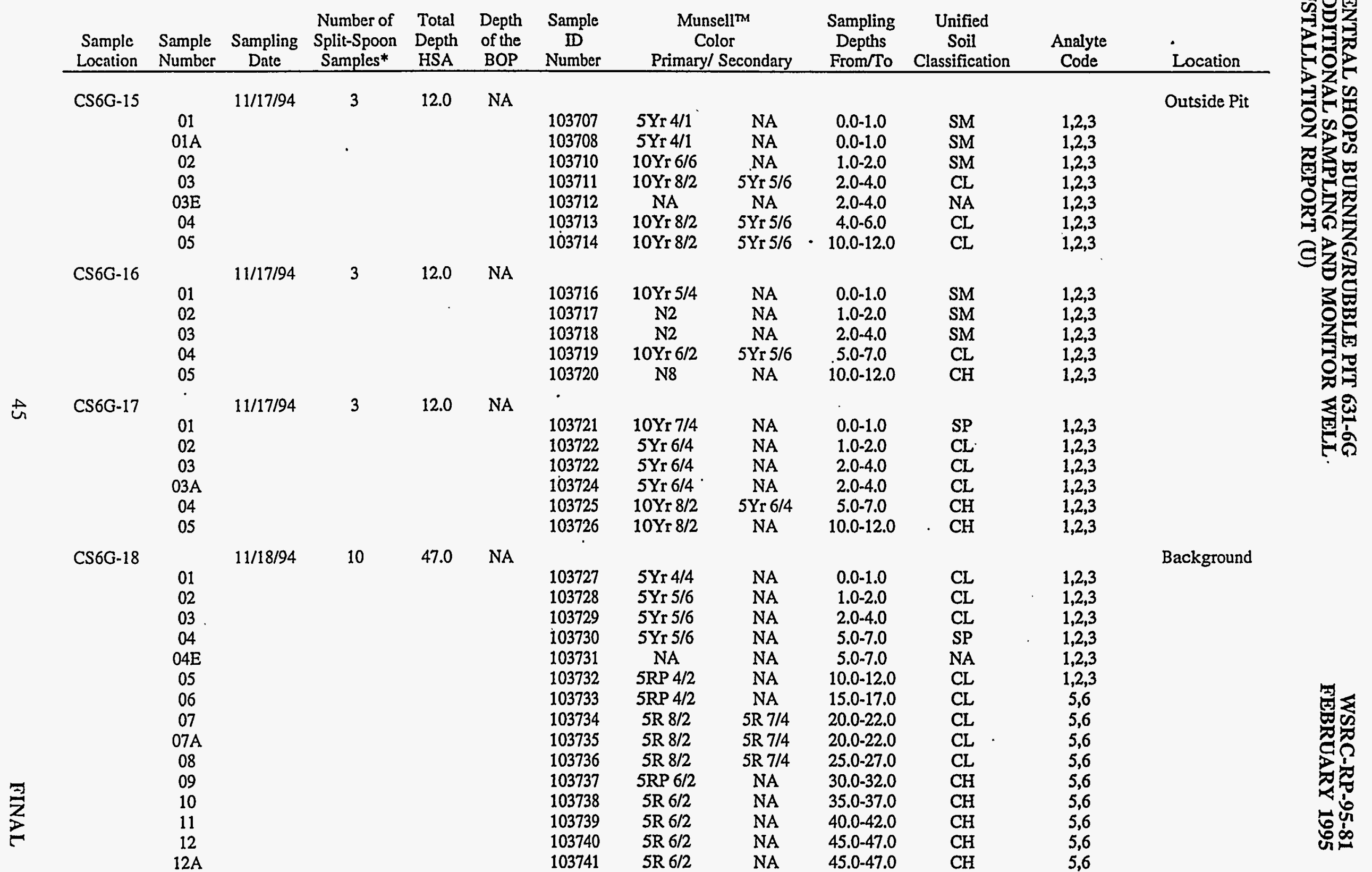


Table 5 (continued)

Summary of Soil, Surface Water/Sediment Sampling

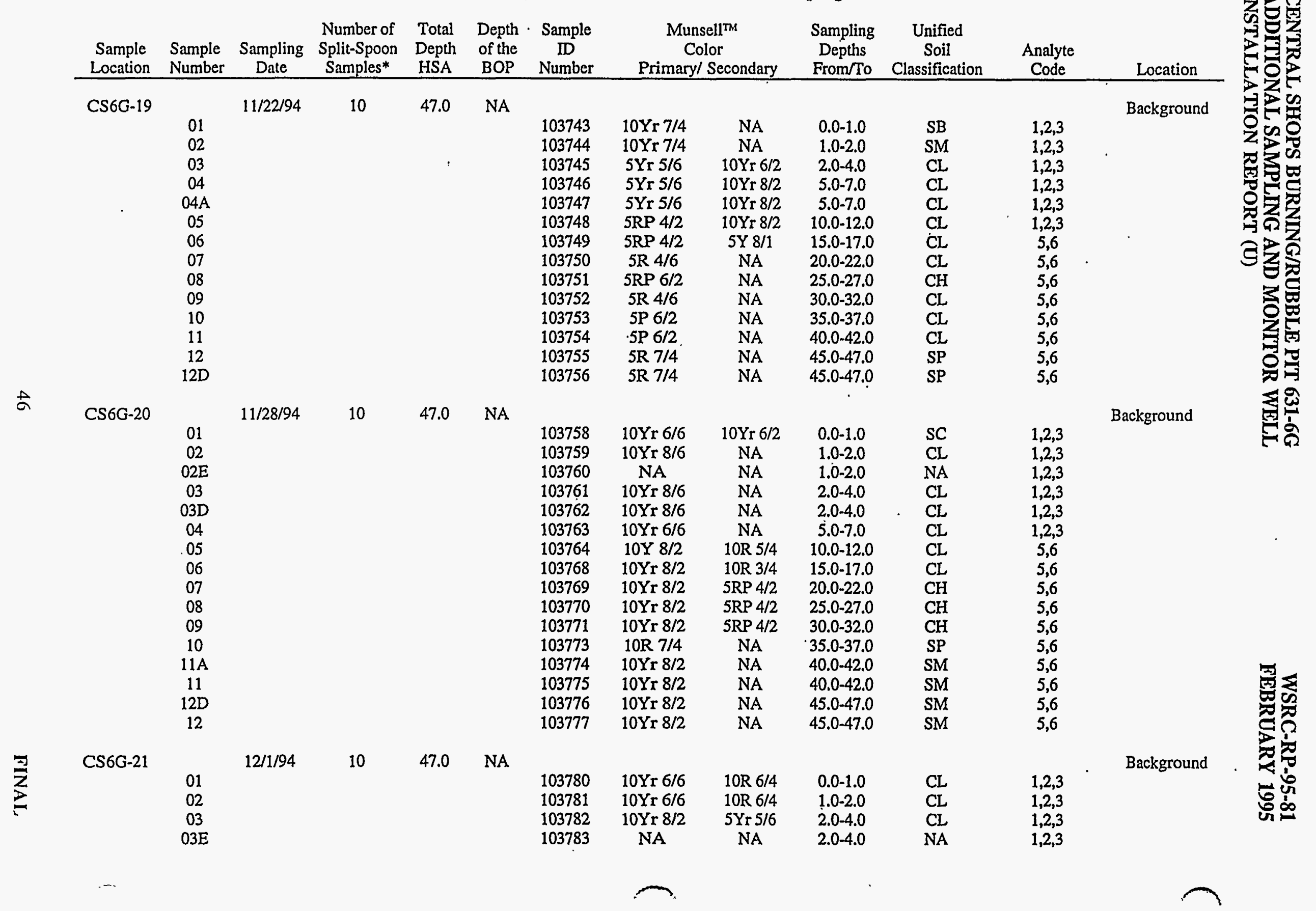


Table 5 (continued)

Summary of Soil, Surface Water/Sediment Sampling

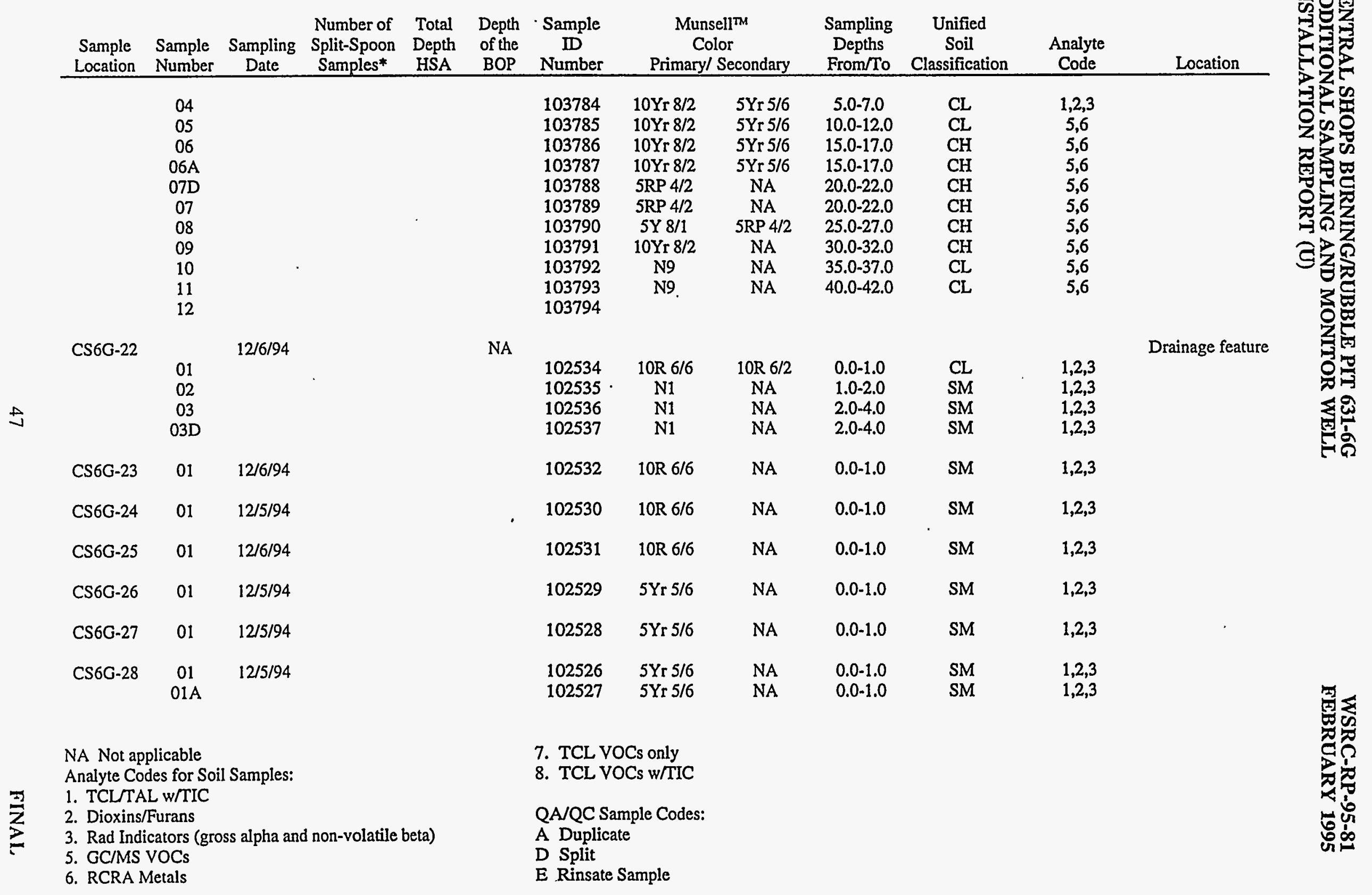


Table 5 (continued)

Summary of Soil, Surface Water/Sediment Sampling

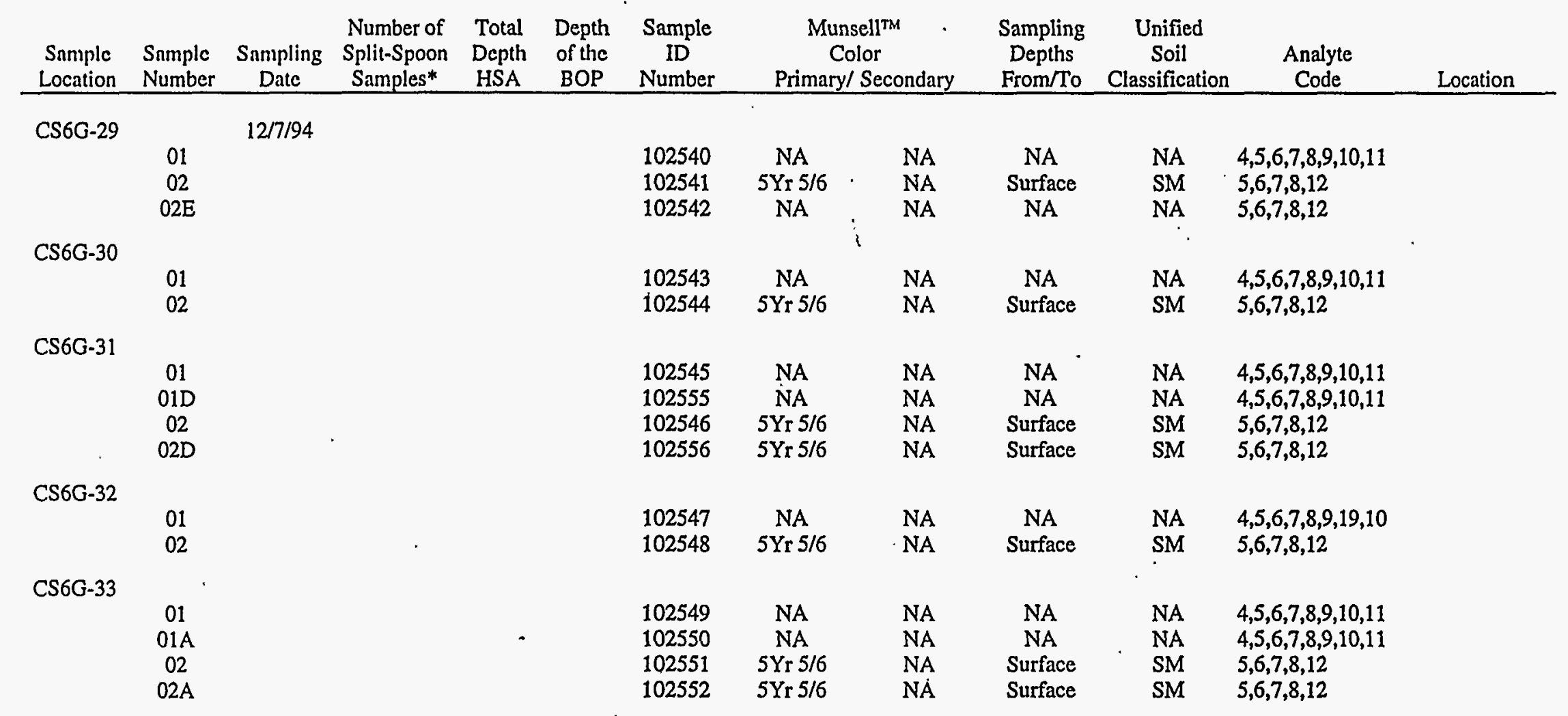

QA/QC Sample Codes:

NA Not applicable

Analyte Codes for Surface Water/Sediment Samples:

1. Total organic halogens

2. Metals ( $\mathrm{Ag}, \mathrm{As}, \mathrm{Ba}, \mathrm{Cd}, \mathrm{Cr}, \mathrm{Cu}, \mathrm{Pb}, \mathrm{Mn}, \mathrm{Hg}, \mathrm{Nl}, \mathrm{Se}$ )

3. Semi-volatile organic constituents, including polycyclic hydrocarbons (PAH)

4. Volatile organic constituents (volatile organic analysis, gas chromatography, mass spectrometer (VOA GC/MS)

A Duplicate

D Split

E Rinsate Sample

5. Radionuclide indicators (gross alpha, nonvolatile bet, total radium) and tritium

6. Surface water tempearture, dissolved oxygen, $\mathrm{pH}$, depth, flow (estimate)

7. Sediment $\mathrm{pH}, \mathrm{TOC}$

8. Inorganics (Cl, F, SO4, NO3, Na, Fe)

9. TOC, TSS, TDS 
Several factors possibly affected the readings that were encountered and the background (ambient readings). The calibration gas (methane) is \pm 2 parts per million (ppm with a minimum detectable limit of $0.2 \mathrm{ppm}$. Another factor is that ambient background readings will vary depending on the geographical location where the instrument is being used. However, background readings should normally be in the range of 3 to $5 \mathrm{ppm}$ when calibrated with methane. An acceptable background reading of 1.0 to $1.5 \mathrm{ppm}$ methane is normal. In addition to the measurement of a normal methane background, 2 to $4 \mathrm{ppm}$ of equivalent methane background can be caused by acceptable levels of contamination in the OVA's hydrogen fuel and/or hydrogen fuel handling system which will result in a total equivalent methane reading of 3 to $5 \mathrm{ppm}$ as background.

Measurements of 6 to 7 ppm may be acceptable background reading depending on site conditions that affect background. The background reading may be zeroed out or nulled even though in reality the background still exists. The background reading is measured by zeroing the meter with the flame out and noting the meter indication after the flame is on.

Possible causes for high background readings from the OVA include:

- impurities in the hydrogen fuel system

- interferences trapped in the porous bronze sample filter of the Mixed/Burner Assembly

- contamination in the air sample line

It is suspected that the listed readings were due to naturally occurring sources, methane from rotting vegetation and/or terpines from pine tree roots located within the vicinity of the boring. Also, the BRP6G unit is located near a recycling yard that had a generator running at all times during the work day. Other deciding factors that may have provided readings were:

- weather, because humidity can effect the accuracy of the OVA by $\pm 20 \%$ of individual full scale

- isopropanol rinse required for equipment decontamination because residual isopropanol on sampling gloves or clothes could have resulted in a high background detection

Table 5 is a summary of drilling depths, sample intervals and other information included in the EPD/EMS Soil Sample Logbook. The bottom of the pit (BOP) and a burnt, black layer with debris 
were encountered in three boreholes inside the pit/unit boundaries (see Table 5). All 12 soil borings were installed, sampled, and abandoned. Section 2.5 provides detailed descriptions for all of the soil borings. Figure 17 depicts the outline of the pit boundary.

\subsection{Surface Water/Sediment Sampling}

\subsubsection{Sampling Locations and Intervals}

A minimum of five surface water and sediment samples (CS6G-29 through CS6G-33) were obtained from the ephemeral stream, located approximately $61 \mathrm{~m}(200 \mathrm{ft})$ southeast of the unit (Figure 4). At the time the unit reconnaissance was made it appeared that the drain was hydrologically influenced solely by surface runoff. Selection of adequate background locations for surface water and sediment sampling does not appear to be possible, considering that the origin of the drain is located downgradient from the unit. The Addendum to Chapter 4 of the RFI/RI Work Plan for the Central Shops Burning/Rubble Pit, 631-6G (Appendix A) provided the proposed analyte list.

Surface water/sediment samples were analyzed for Total Organic Halogens (TOH), RCRA metals, semi-volatile organic compounds [including polycylic hydrocarbons (PAH)], GC/MS VOC, radionuclide indicators and tritium, sediment $\mathrm{pH}$ and TOC, Inorganics, Total Organic Carbon (TOC), Total Suspended Solids (TSS), and Total Dissolved Solids (TDS).

Field measurements of the surface water included water temperature, dissolved oxygen, $\mathrm{pH}$, and estimated flow (Appendix I). QA/QC samples were also analyzed and collected as specified in the Addendum to Chapter 4 of the RFI/RI Work Plan for the Central Shops Burning/Rubble Pit, 6316G. A summary of the surface water/sediment sampling is provided in Table 5.

\subsubsection{Sampling Procedures}

Surface water/sediment sampling was conducted in accordance with procedures specified in the RFI/RI Program Plan and WSRC 3 Q5.

Samples were collected from downstream to upstream locations in order to prevent compromising the sampling locations. Surface water samples were collected first at each location and then the surface sediment sample for that location was collected. Caution was taken to ensure minimum 
INSTALLATION REPORT (U)

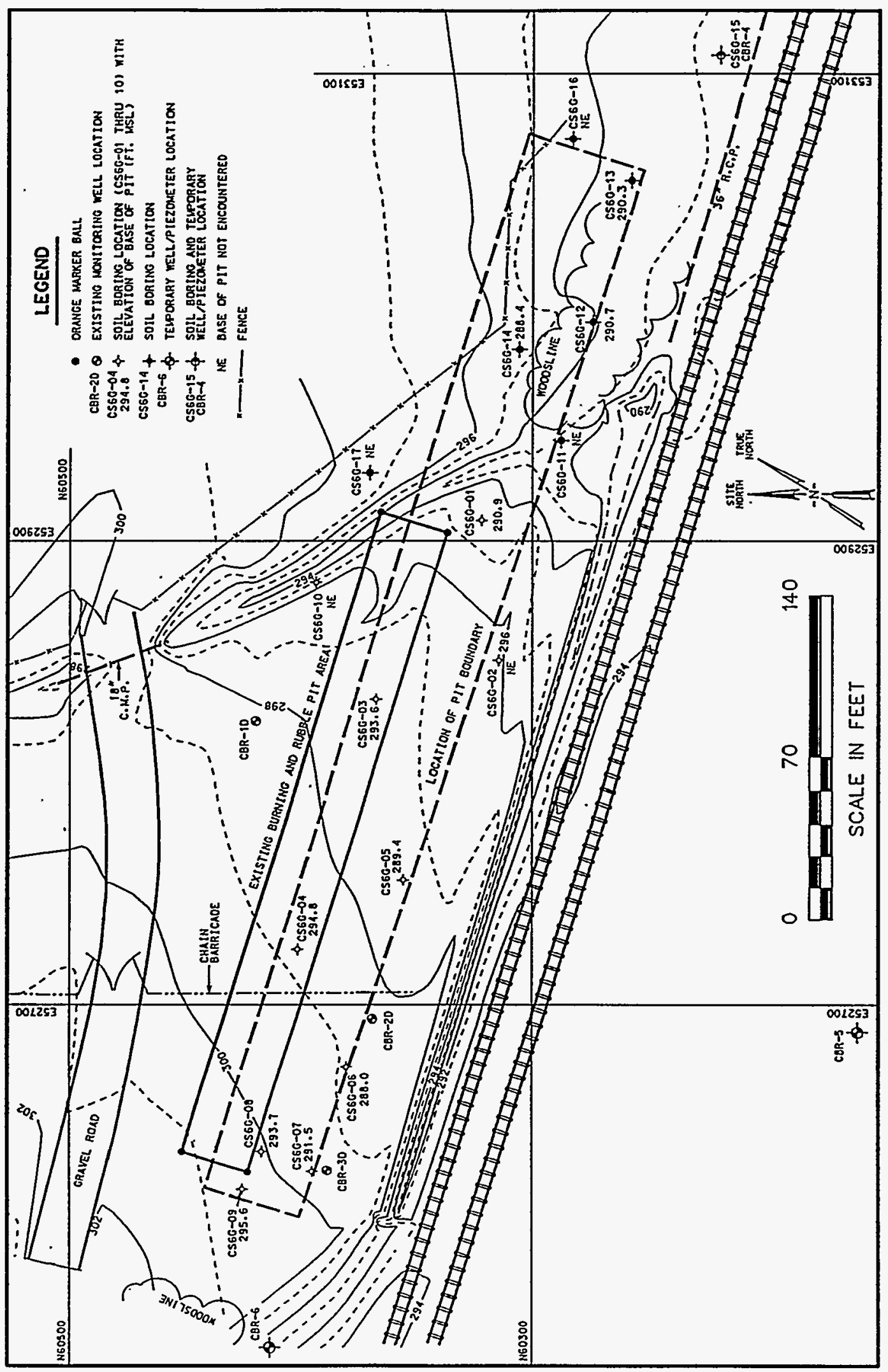

Figure 17. Location of Pit Boundary 
loss of volatiles. All disposable sampling supplies and materials were removed from the waste unit area and disposed of in accordance with current WSRC procedures.

Preparation for sample collection and the use of the EPD/EMS soil sample logbooks were described previously in Section 2.3.2. This method was also used for the surface water/sediment sampling. Decontamination procedures of the sampling equipment was also described in Section 2.3.2. Where applicable, these same methods were employed.

\subsection{Boring Activity/Problems}

\subsubsection{Temporary Groundwater Monitoring Wells}

Field logs, well construction diagrams, and monitoring well installation reports are presented in Appendices $\mathrm{B}$ and $\mathrm{C}$. This section describes any problems associated with well installation.

\section{$\underline{\text { CBR-4 }}$}

Temporary well CBR-4 was installed on November 4, 1994 to a total depth of $18.43 \mathrm{~m}$ (60.48 $\mathrm{ft}$ ) below land surface. This well is located southeast of the pit boundary. Difficulties during well installation included improper placement of the bentonite seal. The use of tremie pipe to place well material (sand, bentonite etc.) at the desired depths is highly effective. However, during installation of bentonite an obstruction between the top of the sandpack $11.15 \mathrm{~m}(36.30 \mathrm{ft})$ and the measured top of bentonite $8.38 \mathrm{~m}(27.5 \mathrm{ft})$ was encountered. The amount of bentonite added to the well should have raised the bentonite to approximately $10 \mathrm{~m}(33.0 \mathrm{ft})$, therefore not accounting for an approximate $1.5 \mathrm{~m}(5 \mathrm{ft})$ section of the well. Since this well was to be considered a temporary well additional bentonite was added to the well and allowed to hydrate for over 48 hours to $5.8 \mathrm{~m}$ (18.9 ft) bls. The additional bentonite was placed to prevent possible portland cement intrusion during placement. This temporary well was considered acceptable for the specified purposes.

\section{CBR-5}

Temporary well CBR-5 was installed on November 3, 1995. The well was installed to a depth of $16.7 \mathrm{~m}(55 \mathrm{ft})$ bls south of the pit boundary. No problems were encountered during drilling or well installation. 


\section{$\underline{\mathrm{CBR}-6}$}

Temporary well CBR- 6 was installed on November 3,1995 . The well was installed to a depth of $18.4 \mathrm{~m}(60.4 \mathrm{ft})$ bls east of the pit boundary. No problems were encountered during drilling or well installation.

\subsubsection{Soil Borings}

Descriptions of drilling and sampling activities for each soil boring are summarized below. Field logs and soil boring installation reports are included in this report as Appendices B and D. Sample numbers, sample dates number of split spoon samples, total depth to the BOP, EPD/EMS Soil Sample Logbook sample ID number, munsell color, sample depth, unified soil classification, analyte code, QA/QC identifier, and location for each soil boring are presented in Table 5. It should be noted all soil borings terminated above the water table were properly abandoned by backfilling with soil cuttings from that soil boring.

\subsubsection{Soil Borings Located Within the Estimated Boundary of BRP6G}

\section{CS6G-11}

This soil boring was installed on November 14, 1994. This boring was proposed within the pit boundary, however visual inspection of the soil sample results did not indicate disturbance and was believed to be located outside the unit boundary. The soil boring was terminated at $2.4 \mathrm{~m}$ ( 8.0 $\mathrm{ft}$ ) bls and the final sample was collected from 2.4 to $3.0 \mathrm{~m}$ ( 8.0 to $10.0 \mathrm{ft}$ ) bls. No OVA readings were above background levels.

\section{CS6G-12}

This soil boring was installed on November 15, 1994. No drilling problems were encountered. This soil boring was located in the eastern part of the original pit. Burn material was observed at $0.45 \mathrm{~m}(1.5 \mathrm{ft})$. Residuum was observed at $1.1 \mathrm{~m}(3.5 \mathrm{ft})$ and assumed to be the BOP. The soil boring was terminated at $1.8 \mathrm{~m}(6.0 \mathrm{ft})$ bls and the final sample was collected from 1.8 to $2.4 \mathrm{~m}$ ( 6.0 to $8.0 \mathrm{ft}$ ) bls. OVA readings were not above background levels. 


\section{CS6G-13}

This soil boring was installed on November 15, 1994. No drilling problems were encountered. This soil boring was located in the eastern part of the original pit. Burn material, including ash, organics, old nails, copper wire, and gravel was observed at from 0.15 to $0.3 \mathrm{~m}(0.5$ to $1.0 \mathrm{ft}) \mathrm{bls}$. Residuum was observed at $1.2 \mathrm{~m}$ ( $3.8 \mathrm{ft}$ ) bls and assumed to be the BOP. The soil boring was terminated at $1.8 \mathrm{~m}(6.0 \mathrm{ft})$ bls and the final sample was collected from 1.8 to $2.4 \mathrm{~m}(6.0$ to $8.0 \mathrm{ft})$ bls. OVA readings were not above background levels.

\section{CS6G-14}

This soil boring was installed on November 16,1994 . No drilling problems were encountered. This soil boring was located in the eastern part of the original pit. Burn material, including ash, black burned wood, glass fragments miscellaneous nails, concrete rubble, and yellow plastic was observed at from 1.5 to $2.13 \mathrm{~m}$ ( 5.0 to $7.0 \mathrm{ft}$ ) bls. Residuum was observed at $2.13 \mathrm{~m}(7.0 \mathrm{ft}) \mathrm{bls}$

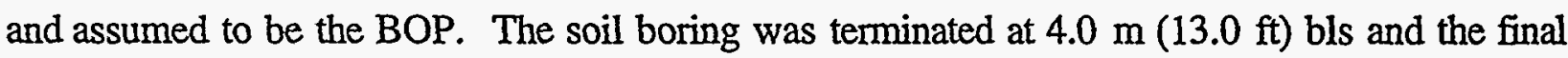
sample was collected from 4.0 to $4.6 \mathrm{~m}$ (13.0 to $15.0 \mathrm{ft}$ ) bls. OVA readings were above background levels as noted in Section 2.3.3.

\subsubsection{Soil Borings Located Outside the Estimated Boundary of BRP6G}

\section{CS6G-15}

This soil boring was installed on November 17, 1994. No drilling problems were encountered. This soil boring was proposed outside and southeast of the original pit. This soil boring was to be sampled at intervals consistent with the borings inside the pit. This boring was terminated at $3.0 \mathrm{~m}$ (10.0 ft) bls and the final sample was collected from 3.0 to $3.6 \mathrm{~m}$ (10.0 to $12.0 \mathrm{ft}$ ) bls. OVA readings were not above background levels.

\section{CS6G-16}

This soil boring was installed on November 17, 1994. No drilling problems were encountered. This soil boring was proposed outside and east of the original pit. This soil boring was to be sampled at intervals consistent with the borings inside the pit. This boring was terminated at $3.0 \mathrm{~m}$ $(10.0 \mathrm{ft})$ bls and the final sample was collected from 3.0 to $3.6 \mathrm{~m}(10.0$ to $12.0 \mathrm{ft}) \mathrm{bls}$. OVA 
readings above background levels were 6.0 and $15.0 \mathrm{ppm}$ from samples collected from 0.3 to 0.6 $\mathrm{m}(1.0$ to 2.0$) \mathrm{ft}$ and 0.6 to $1.2 \mathrm{~m}(2.0$ to $4.0 \mathrm{ft})$, respectively.

\section{CS6G-17}

This soil boring was installed on November 17, 1994. No drilling problems were encountered. This soil boring was proposed outside and east of the original pit. This soil boring was to be sampled at intervals consistent with the borings inside the pit. This boring was terminated at $3.0 \mathrm{~m}$ (10.0 ft) bls and the final sample was collected from 3.0 to $3.6 \mathrm{~m} \mathrm{(10.0} \mathrm{to} 12.0 \mathrm{ft}) \mathrm{bls}$. OVA readings above background levels were 3.0 and $6.0 \mathrm{ppm}$ from samples collected from 0.3 to $0.6 \mathrm{~m}$ (1.0 to 2.0$) \mathrm{ft}$ and 0.6 to $1.2 \mathrm{~m}$ ( 2.0 to $4.0 \mathrm{ft}$ ), respectively.

\subsubsection{Background Soil Boring Locations}

\section{CS6G-18 Through CS6G-21}

Background soil boring locations, CS6G-18 through CS6G-21, were chosen by a WSRC soil scientist. Presently, the soil boring locations have not been surveyed and not located on Figure 3. These soil borings were installed between November 18 and December 1, 1994 and exact dates are presented on Table 5. All of these borings were drilled and sampled at predetermined depths as shown in Table 5. There were no drilling problems associated with soil boring installation outside of delays due to rain.

\subsubsection{Soil Boring in Drainage Feature}

A drainage feature running through the eastern portion of the pit boundary was suspect as being a source of horizontal impact. A soil boring CS6G-22 was performed on December 6, 1994. This boring was proposed to evaluate the potential for contaminants from the pit to impact storm water runoff associated with the drainage feature. Burn material was observed at $0.45 \mathrm{~m}(1.5 \mathrm{ft})$ to boring termination at $1.1 \mathrm{~m}(3.5 \mathrm{ft})$ bls. 


\subsection{SUMMARY}

Preliminary results from the 1994 unit characterization indicate that contamination is present in the RFI/RI unit soils. As stipulated in the Rev. 2 RFI/RI work plan, a downgradient groundwater monitoring well is to be installed in the water table aquifer. To help determine a permanent location for the groundwater monitoring well, three temporary groundwater monitoring wells were installed, developed sampled and slug tested (one to the west, one to the south, and one to the southeast. Water level data from these wells helped determine the hydraulic gradient of the groundwater. The hydraulic conductivity estimates were fairly typical for the lithologies encountered. Groundwater samples were collected for VOCs in two separate phases.

Twelve soil borings were-installed, sampled, and abandoned in the BRP6G as part of the additional unit assessment activities of the Central Shops 631-6G RFI/RI. Soil samples were collected at designated intervals for TALTCL with TIC, Dioxins/Furans, radionuclide indicators, GC/MS VOCs, RCRA metals and/or TCL VOCs only. The bottom of the pit was encountered in three of the boreholes. A burnt, black layer was found in three of these boreholes within the pit.

Surficial soil samples were collected at six locations with in the ditch located along the railroad, south of the pit. These samples were analyzed for TAL/TCL with TIC, Dioxins/Furans and radionuclide indicators. Five surface water/sediment samples were collected from the ephemeral stream approximately $61 \mathrm{~m}$ (200 ft) southeast of the unit. These samples were analyzed for TOH, RCRA metals, semi-volatiles, GCMS VOCs, radionuclide indicators and tritium, inorganics, TOC, TSS, and TDS. The surface sediments were analyzed for $\mathrm{pH}$. The surface water was analyzed in the field for water temperature, dissolved oxygen, $\mathrm{pH}$, depth, and estimated flow. The analytical results from these soil samples will be produced by General Engineering Laboratories of Charleston, South Carolina, and published in another report. 


\section{REFERENCES}

Aadland, R. K., A. D. Smits, and P. A. Thayer, 1992. Geology and Hydrostratigraphy of the A/M Area, Savannah River Site (SRS), South Carolina (U), WSRC-RP-92-440, Westinghouse Savannah River Company, Savannah River Site, Aiken, SC.

Aadland, R. K., and H. W. Bledsoe, 1990. Classification of Hydrostratigraphic Units at the Savannah River Site, South Carolina, WSRC-RP-90-987, Westinghouse Savannah River Company, Savannah River Site, Aiken, SC.

Bledsoe, H.W., R.K. Aadland, and K.A. Sargent, 1990. SRS Baseline Hydrogeologic Investigation - Summary Report. WSRC-RP-90-1010, Westinghouse Savannah River Company, Savannah River Site, Aiken, SC.

Bouwer, H. and R. C. Rice, 1976. A Slug Test for Determining Hydraulic Conductivity Of Unconfined Aquiers with Completely or Partially Penetrating Wells, Water Resources Research, Vo. 12, No. 3.

Fallaw, W. C., 1991. Subsurface Stratigraphy and Structure of the A/M Area at the Savannah River Site, USDOE Report WSRC-RP-91-830, prepared for Westinghouse Savannah River Company, Westinghouse Savannah River Laboratory, Aiken, SC.

Gordon, D.E., W.F. Johnson, D.S. Kaback, B.B. Looney, R.L. Nichols, C.B. Shedrow, 1987. Characterization Recommendations for Waste Sites at the Savannah River Plant, DPST87-667, E.I. duPont de Nemours and Company, Savannah River Laboratory, Aiken, SC.

Haselow, J.S. and M.D. Taylor, 1989. Numerical Simulation of Flow and Contaminant Transport at the $K, L$, and P Areas of the Savannah River Site. WSRC-RP-89-1198, Westinghouse Savannah River Company, Savannah River Site, Aiken, SC.

Lewis, S. E., and R. K. Aadland, 1992. Hydrogeologic Setting of the AMM Area: Frameworkfor Groundwater Transport (U), WSRC-TR-92-355, Westinghouse Savannah River Company, Savannah River Site, Aiken, SC.

Looney, B.B., M. Randeem, J. Pickett, V. Rogers, P.A. Shirley, and M.T. Scott, 1989. Geochemical and Physical Properties of Soils and Shallow Sediments at the Savannah River Plant (Draft). WSRC-RP-91-1031, Westinghouse Savannah River Company, Savannah River Site, Aiken, SC.

Price, V., 1988. "Subsurface Hydrogeology," in Stephenson, A.2., ed., Final Safety Analysis Report for DWPF (Draft). DPSTSA-200-10, E.I. duPont de Nemours and Company, Savannah River Plant, Aiken, SC.

Rogers, V.A., 1990. Soil Survey of Savannah River Plant Area Parts of Aiken, Barnwell, and Allendale Counties, South Carolina: USDA Soil Conservation Service.

South Carolina Department of Health and Environmental Control (SCDHEC), 1985. South Carolina Well Standards and Regulations, R. 61-71. June 1985.

Todd, D.K., 1959. Ground Water Hydrology. Wiley and Sons. 
Westinghouse Savannah River Company (WSRC), 1992, or most recent version. Hydrogeologic Data Collection Methods, Procedures and Specifications, WSRC 3Q5 (formerly DPSOP 254), adapted by WSRC from E. I. duPont de Nemours and Company, Savannah River Site, Aiken, SC.

Westinghouse Savannah River Company (WSRC), 1993a. RCRA Facility Investigation/RI Program Plan. WSRC-RP-89-994, Revision 1, Westinghouse Savannah River Company, Savannah River Site, Aiken, SC.

Westinghouse Savannah River Company (WSRC), 1993b. RFI/RI Work Plan for Central Shops Burning/Rubble Pit 631-6G. WSRC-RP-90-1136, Revision 2: Westinghouse Savannah River Company, Savannah River Site, Aiken, SC.

Westinghouse Savannah River Company (WSRC), 1994a. Central Shops Burning/Rubble Pit 631-6G Soil Sampling Report. WSRC-RP-94-382, Revision 2. Westinghouse Savannah River Company, Savannah River Site, Aiken, SC.

Westinghouse Savannah River Company (WSRC), 1994b. Historical Photographic Search of Central Shops Waste Unit 631-6G, Interim Report. WSRC-RP-94-0000, Draft.

Westinghouse Savannah River Company, Savannah River Site, Aiken, SC. 
Appendix A

\section{Addendum 4.0}

Additional Sampling and Groundwater Monitor Well Installation for the

RFI/RI Work Plan for Central Shops Burning/Rubble Pit, 631-6G 


\section{ADDENDUM 4.0 ADDITIONAL SOIL SAMPLING AND GROUNDWATER MONITORING WELL INSTALLATION}

Addendum 4.0 is required to conduct additional sampling at the Central Shops Burning Rubble Pit 631-6G (CSBRP6G) RCRA/CERCLA Unit. This additional sampling is based on information obtained during unit characterization sampling conducted in March and April 1994 and observations in the historical aerial photography of the area.

SRS conducted a review of historical aerial photographs which indicates that the waste unit is not accurately marked in the field, and the location extends an additional 100-125 feet further east of the waste unit markers (orange balls). The photographs also showed that the pit was in operation from 1951 through 1955. In addition, the ditch immediately adjacent to the eastern most edge of the marked unit runs through the original waste unit and a portion of the waste unit is more than likely being used currently (1994) as a laydown yard.

The additional sampling will be conducted at a total of 12 soils locations (Figure 4-A1). Four locations are inside the estimated location of the waste unit, three locations are just outside the unit, and five background locations (not shown) will be selected. Specific background soil sample locations will be selected in cooperation with a soil taxonomist at the time the sampling is conducted. The soil taxonomist will select locations which are considered beyond the area that potentially may have been impacted from waste disposal activities at the unit. In addition, 6 surficial (0-1 foot) soil samples will be obtained within the ditch located along the railroad, south of the pit. Three of the samples will be selected within the ditch, upgradient and beyond the area of potential ash deposition. The remaining five samples will be collected within the ditch, downgradient from the pit. The total number of samples proposed for collection at each of the sampling locations is listed in Table 4-A1, including an additional 10 percent to be collected for quality assurance/quality control purposes. The proposed analyte list, identical to the analytical program used during the 1994 unit characterization sampling and outlined in section 4.3, is also detailed in Table 4-A1. 
A minimum of five surface water and sediment samples will be obtained from the ephemeral stream, located approximately 200 feet southeast of the pit (Figure 4-A2). At the time the unit reconnaissance was made it appeared that the drain was hydrologically influenced solely by surface runoff. Selection of adequate background locations for surface water and sediment sampling does not appear to be possible, considering that the origin of the drain is located downgradient from the unit. Table 4-A2 provides the analyte list.

Preliminary results from the 1994 unit characterization indicate that contamination is present in the RFI/RI unit soils. A downgradient groundwater monitoring well will be installed in the water table aquifer, an action stipulated in the section 4.4 , if contamination is detected in the unit soils. To help determine a permanent location for the monitoring well, three temporary well piezometers will be installed (as shown in Figure 4-A1) per WSRC 3Q5, one to the west, one to the south, and one to the southeast. Water level data from these wells will help determine the hydraulic gradient of the groundwater. Table 4-A3 provides a list of the temporary wells/piezometers and analyses required. One or more of the wells/piezometers will be chosen to be a permanent monitoring well. The remaining temporary wells/piezometers will be abandoned.

If preliminary characterization -results (including results from this addendum) indicate the potential for notable ecological impact, then ecological sampling may be required.

All sampling, analytical activities, and groundwater monitoring well installations will follow the approach outlined in this RFI/RI Work Plan. 


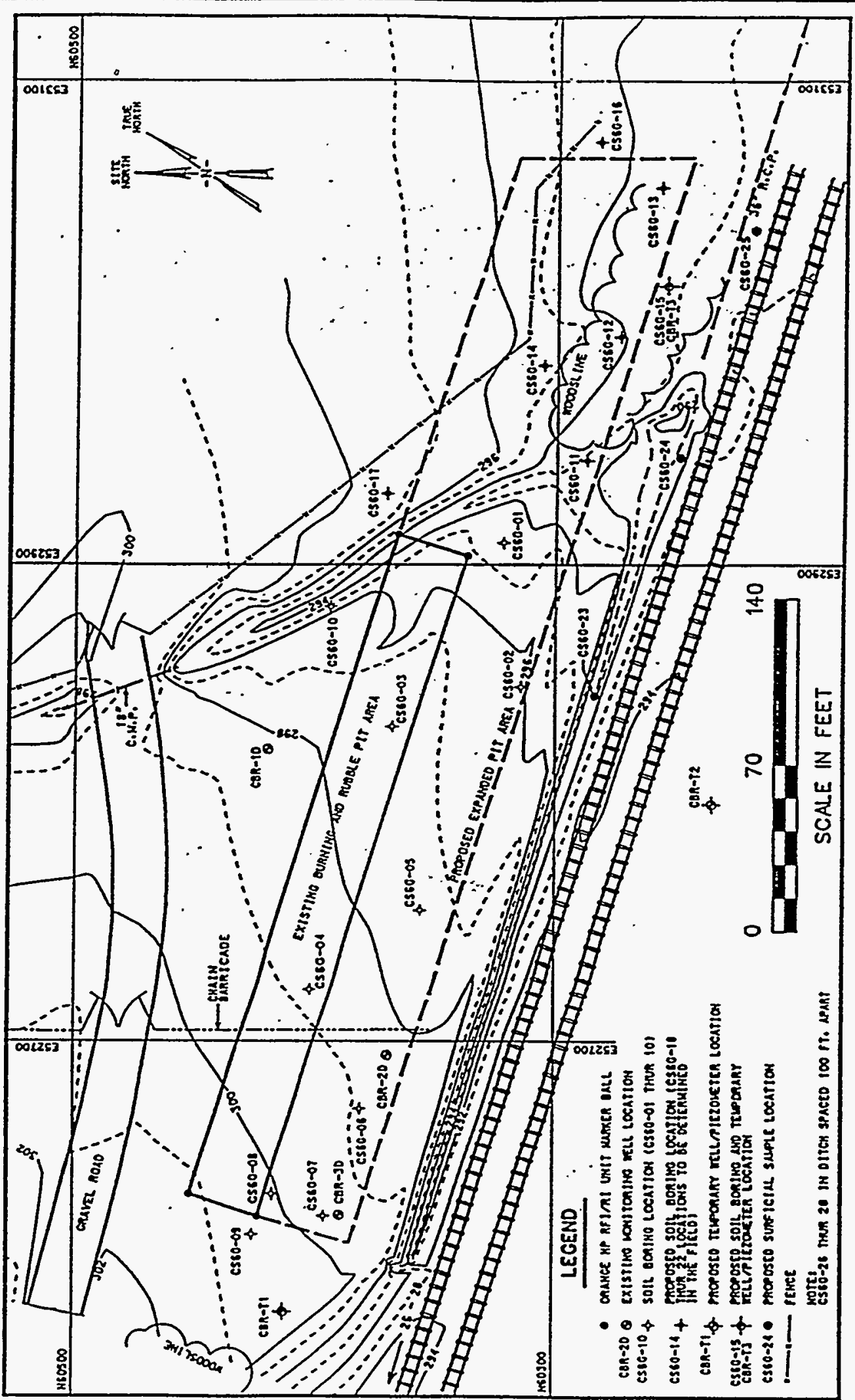

Figure 4-A1. Additional Soil Sampling and Well Piezometer Installation Locations 


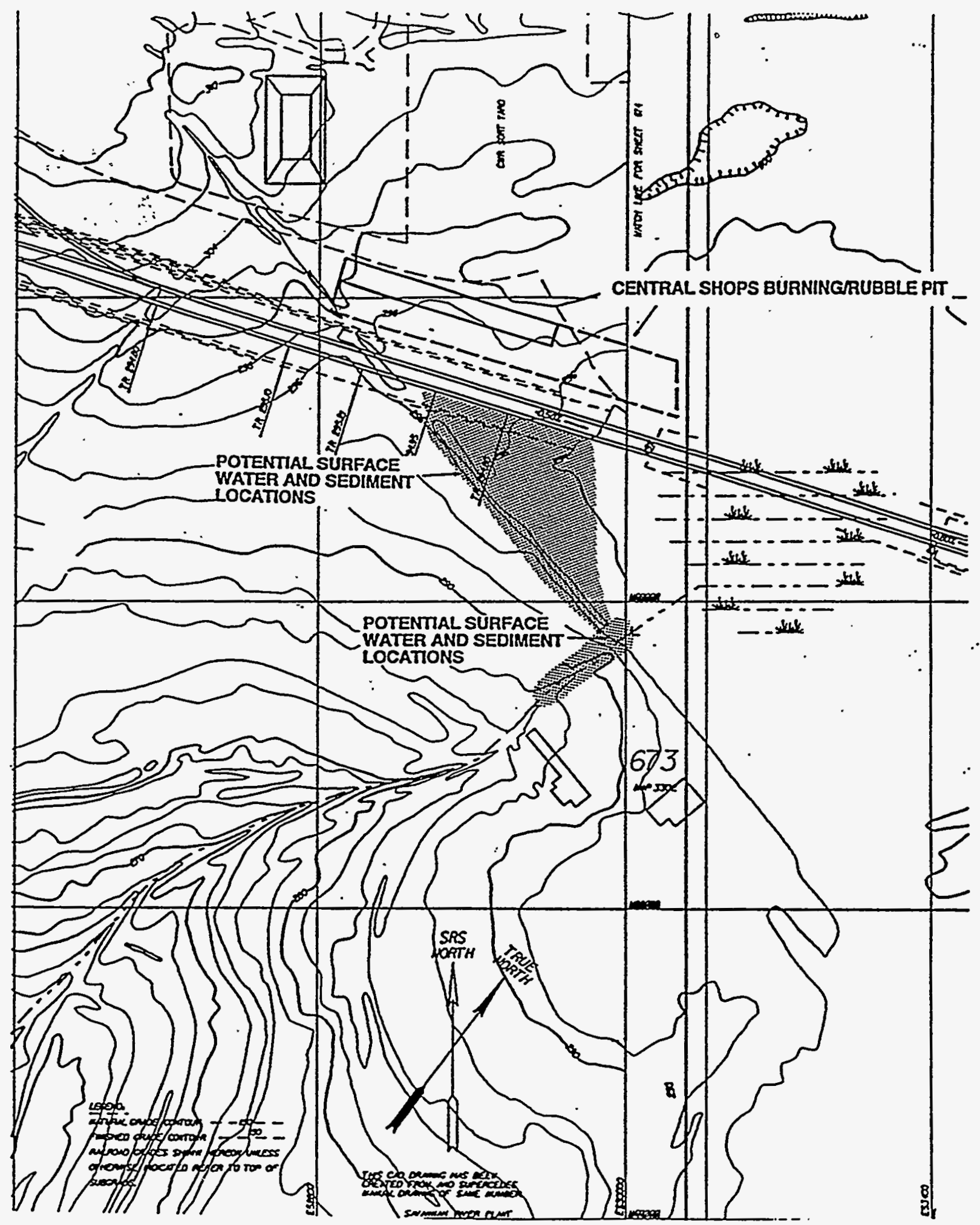

Figure 4-A2. Surface Water and Sediment Sample Locations 


\section{Table 4-A1}

\section{Analytical Parameters for Soil and Surfical Sediment Samples}

\begin{tabular}{|c|c|c|c|c|c|c|}
\hline FACILITY & SAMPLE & SAMPLE & SAMPLE & - SAMPLE & SAMPLE INT. " & ANALYTE \\
\hline IDENTIFIER & PT INUM INSTRUMENT & S. TYPE $\cdots$ & LOCATION $\ldots .$. & TOP./BOTTOM & CODE \\
\hline
\end{tabular}

\begin{tabular}{|c|c|c|c|c|c|c|c|c|}
\hline CS6G & 11 & .01 & Hand Auger. & $\because \therefore$ Soil & Surface inside pit & 0.0 & 1.0 & 123 \\
\hline CS6G & 11 & 02 & Hand Auger. & $\therefore$ Soil & $\because \therefore \quad \therefore$ Inside pit & 1.0 & 2.0 & $\therefore \quad 123$ \\
\hline CS6G & 11 & 03 . & Split-spoon & $\because$ Soil & Inside pit & 2.0 & $4.0 \Delta$ & $\therefore 123$ \\
\hline CS6G & 11 & 0.4 & Split-spoon & Soil & +1 to -1 tt BOP & & & 123 \\
\hline CS6G & 11 & $4 A$ & Split-spoon & Duplicate & +1 to -1 ft BOP & & & 123 \\
\hline CS6G & 11 & 05 & Split-spoon & Soil & -1 to -3 ft BOP & & & 123 \\
\hline CS6G & 11 & 06 & Split-spoon & Soil & -3 to $-5 \mathrm{ft} B O P$ & & & 123 \\
\hline CS6G & 11 & 07 & Split-spoon & Soil & -10 to $-12 \mathrm{ft}$ BOP & & & 56 \\
\hline CS6G. & 11 & 08 & Split-spoon & Soil & -15 to $-17 \mathrm{ft}$ BOP & & & 56 \\
\hline CS6G & 11 & 09 & Split-spoon & Soil & -20 to $-22 \mathrm{ft}$ BOP & & & 56 \\
\hline CS6G & 11 & 10 & Split-spoon & Soil & -25 to $-27 \mathrm{ft}$ BOP & & & .56 \\
\hline CS6G & 11 & 11 & Split-spoon & Soil & -30 to $-32 \mathrm{ft} \mathrm{BOP}$ & & & 56 \\
\hline CS6G & 11 & 12 & Split-spoon & Soil & -35 to $-37 \mathrm{ft} \mathrm{BOP}$ & & & 56 \\
\hline CS6G & 11 & 13 & Split-spoon & Soil & -40 to $-42 \mathrm{ft}$ BOP & & & 56 \\
\hline CS6G & 11 & 14 & Split-spoon & Soil & -45 to $-47 \mathrm{ft}$ BOP & & & 56 \\
\hline CS6G & 12 & 01 & Hand Auger & Soil & Surface inside pit ** & 0.0 & 1.0 & 123 \\
\hline CS6G & 12 & 02 & Hand Auger & Soil & Inside pit & 1.0 & 2.0 & 123 \\
\hline CS6G & 12 & 03 & Split-spoon & $-\cdots-$ Soil & Inside pit & 2.0 & $4.0 \Delta$ & 123 \\
\hline CS6G & 12 & 04 & Split-spoon: & - - Soil & +1 to $-1 \mathrm{ft}$ BOP & & - & 123 \\
\hline CS6G & 12 & 05 & Split-spoon & Soil & $\because-1$ to $-3 \mathrm{ft}$ BOP & & & $\therefore 123$ \\
\hline CS6G & 12 & 06 & Split-spoon & Soil & -3 to $-5 \mathrm{ft}$ BOP & & $\because$ & 123 \\
\hline CS6G & 12 & 07 & Split-spoon & Soil & -10 to -12 ft BOP & & & $\therefore 56{ }^{\circ}$ \\
\hline CS6G & 12 & 08 & Split-spoon & Soil & -15 to $-17 \mathrm{ft}$ BOP & & & 56 \\
\hline CS6G & 12 & 09 & Split-spoon & Soil & -20 to $-22 \mathrm{ft}$ BOP & & & 56 \\
\hline CS6G & 12 & $9 A$ & Split-spoon & Duplicate & -20 to $-22 \mathrm{ft}$ BOP & & & 56 \\
\hline CS6G & 12 & 10 & Split-spoon & Soil & -25 to $-27 \mathrm{ft}$ BOP & & & 56 \\
\hline CS6G & 12 & 11 & Split-spoon & Soil & -30 to $-32 \mathrm{ft}$ BOP & & & 56 \\
\hline CS6G & 12 & 12 & Split-spoon & Soil & -35 to $-37 \mathrm{ft}$ BOP & & & 56 \\
\hline CS6G & 12 & 13 & Split-spoon & Soil & -40 to $-42 \mathrm{ft}$ BOP & & & 56 \\
\hline CS6G & 12 & 14 & Split-spoon & Soil & -45 to -47 ft BOP & & - & 56 \\
\hline CS6G & 13 & 01 & Hand Auger & Soil & Surface inside pit "* & 0.0 & 1.0 & 123 \\
\hline CS6G & 13 & 02 & Hand Auger & Soil & Inside pit & 1.0 & 2.0 & 123 \\
\hline CS6G & 13 & 03 & Split-spoon & Soil & Inside pit & 2.0 & $4.0 \Delta$ & 123 \\
\hline CS6G & 13 & 04 & Split-spoon & Soil & +1 to $-1 \mathrm{ft}$ BOP & & & 123 \\
\hline CS6G & 13 & 05 & Split-spoon & Soil & -1 to $-3 \mathrm{ft}$ BOP & & & 123. \\
\hline CS6G & 13 & 06 & Split-spoon & Soil & -3 to -5 ft BOP & & & 123 \\
\hline CS6G & 13 & 07 & Split-spoon & Soil & -10 to $-12 \mathrm{ft}$ BOP & & & 56 \\
\hline CS6G & 13 & 08 & Split-spoon & Soil & -15 to -17 ft BOP & & & 56 \\
\hline CS6G & 13 & 09 & Split-spoon & Soil & -20 to -22 ft BOP & & & 56 \\
\hline CS6G & 13 & 10 & Split-spoon & Soil & -25 to -27 ft BOP & & & 56 \\
\hline
\end{tabular}




\begin{tabular}{|c|c|c|c|c|c|c|c|c|}
\hline$\varepsilon 己 L$ & 0.21 & 0.01 & 1!d өp!sı̣no & 1105 & uoods-1!!ds & 90 & 91 & 5950 \\
\hline$\varepsilon Z L$ & $0 \% 2$ & 0.9 & म!d әp!̣şno & $1 ! 05$ & uoods- $-1 ! 1 d s$ & to & 91 & פ9S5 \\
\hline$\varepsilon Z 1$ & 0.6 & 0.2 & y!d әp!sıno & 1105 & uoods-1!ds & $\varepsilon 0$ & 91 & 5950 \\
\hline$\varepsilon 21$ & 0.2 & 0.1 & I!d op!sino әכejuns & 1105 & JəEn४ PUEH & 20 & 91 & 59S0 \\
\hline$\varepsilon 21$ & 0.1 & $0^{\circ} 0$ & $\neq$ H!d өp!sino әoejuns & I!OS & Jabny pueH & 10 & 91 & 99Sว \\
\hline$\overline{99}$ & $0^{\circ} \angle t$ & 0.96 & 7!d өp!sino & 1105 & uoods-1!!ds & $2 L$ & St & 5950 \\
\hline $9 S$ & 0.27 & 0.06 & l!d өp!s!no & 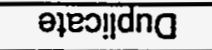 & uoods-1!!ds & $\forall I L$ & SI & 59S5 \\
\hline 99 & 0.26 & 0.00 & ł!d өp!̣sino & l!OS & uoods-1!lds & If & S1 & פ9S0 \\
\hline 99 & $0^{\circ} \angle \varepsilon$ & $0.5 \varepsilon$ & 4!d өp!sino & $1 ! 05$ & uoods-1!!ds & Of & St & 5950 \\
\hline 99 & $0.2 \varepsilon$ & $0.0 \varepsilon$ & I!d $\theta p ! s ! n o$ & 1105 & uoods-1!!ds & 60 & SL & 9950. \\
\hline 99 & $0.2 Z$ & 0.92 & h!d ap!sino & $1 ! 0 S$ & uoods-4!!ds & 80 & SI & 59S0 \\
\hline $9 S$ & $0 . \mathrm{ZZ}$ & 0.02 & y!d әp!รno & IIOS & uoods-4!!ds & 20 & St & 99S5 \\
\hline 99 & 0021 . & 0.91 & y!d ep!sqno & $1 ! 05$ & uoods-1!!ds & 90 & SL & 59S0 \\
\hline$\varepsilon \varepsilon_{L}$ & 0.21 & 0.01 & t!d әp!sqno & 1105 & uoods-4!!ds & SO & $S 1$ & 59S5 \\
\hline EZ! & $0^{\circ} \mathrm{L}$ & 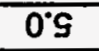 & y!d ap!sino & 1105 & - uoods-?!nds & 70 & SI & 9950 \\
\hline$\varepsilon \varepsilon_{1}$ & 0.6 & 0.8 & H!d ap!sıno & $1 ! 05$ & uoods-1!nds & $\varepsilon 0$ & $\mathcal{S l}$ & 5950 \\
\hline $.8 Z L$ & $0 \%$ & 0.1 & $\cdots "$ म!d op!şno .. & әฺEग!ावna & uoods-1!!ds & $\forall 2$ & Sl & 5950 \\
\hline EZL - & $0 \%$ & 0.1: & 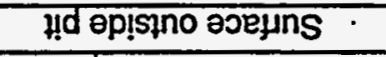 & 1105 & IOEn $\forall$ PUEH & 20 & $\mathbf{S I}$ & 9950 \\
\hline EZI & 0.1 & 0.0 & $\neq$ 1!d ap! & $1 ! 05$ & JəEnళ pUEH & 10 & S1 & 9950 \\
\hline 99 & & & $d 08 H \angle t-015 b^{-}$ & 1105 & uoọds-1!!ds & 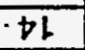 & $7 t$ & 5950 \\
\hline 99. & & & $\because$ dOQHCt- Ol 0t- & $110 \mathrm{~S}$ & uoods-1!!ds & $\varepsilon !$ & 71 & 9950 \\
\hline $99 \ldots$ & $\therefore \div$ & $\cdots$ & $\therefore d O 9 \# \angle E-01$ SE- & $=-1105$ & uoods-l!!ds & $2 L$ & $b t$ & פ9S5: \\
\hline 99 & $\cdots \cdots \cdots$ & & $\because$ dOQH ZE- O। 0ह- & $\cdots \ldots 105 \ldots$ & uoods-1!!ds. & H. & $\cdot t h$ & פ9S5 \\
\hline 99 & & & dOQHLZ-OIGZ- & 1105 & uoods-1!js & Ot & 76 & 5950 \\
\hline 99 & & & dOg H ZZ- 01 0z- & 1105 & uoods-1!!ds & 60 & $7 t$ & 5950 \\
\hline 99 & & & dOgH $\angle L-O$ O 아- & 1105 & uoods-1!!ds & 80 & $7 t$ & 5950 \\
\hline 99 & & & dOQHZL-OIOL- & әाeग!dna & uoods-r!!ds & $\forall L$ & th & 5950 \\
\hline 99 & & & dOGHCL-OlOL- & 1105 & uoods-1!nds & $\angle 0$ & th & Э9Sว \\
\hline$\varepsilon 己 !$ & & & dOgHS-0ㅌ- & 1105 & uoods-i!!ds & 90 & +1 & 9950 \\
\hline EZ! & & & dOQH $\varepsilon^{-}$여 L- & H!dS & uoods-1!!ds & SO & 71 & 9950 \\
\hline$\varepsilon 己$ & & & dOgHL-01Lt & $1 ! 05$ & uoods-1!!ds & to. & 71 & 5950 \\
\hline$\varepsilon 己$ & $\nabla 0 \%$ & $0 \%$ & u!d өp!su! & !10S & uoods-1!nds & 80 & 71 & פ9S5 \\
\hline EZL. & $0 \%$ & 0.1 & I!d əp!̣su & .1105 & Ján, pueH & 20 & 72 . & 9950 \\
\hline$\varepsilon 己 L$ & 0.1 & 0.0 & 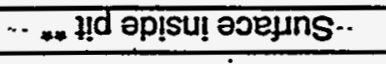 & 1105 & נəбnҰ pueH & LO & $7 t$ & 9950 \\
\hline 99 & & 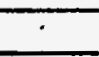 & dOQH $\angle t-015 b^{-}$ & 1105 & uoods-!!!ds & $\$ 1$ & $\varepsilon 1$ & 5950 \\
\hline 99 & & & dOgHZt-010t- & 1105 & uoods-1!!ds & Et & $\varepsilon t$ & כ9S0 \\
\hline 99 & 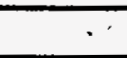 & . & $\because$ dOQHLE-01 $9 \varepsilon^{-}: \because$ & 1105 & uoods-1!|ds & 21 & $\varepsilon L$ & 5950 \\
\hline 99 & & & dO8HZE-0108- & eleo!ldna & uoods-1!lds & IL. & $\varepsilon L$. & פ950 \\
\hline $99 \cdot \therefore:$ & $\therefore$ & & dOQH ZE- $108+\ldots$ & $\ldots 1105 . \cdots$ & .uoods-1!]ds... & 11 & $\varepsilon l$ & 59S0 \\
\hline
\end{tabular}

3000 - WOLl109 dOL,

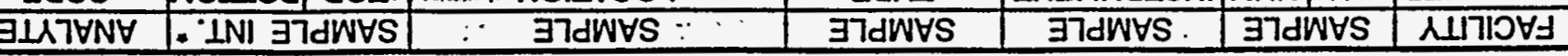

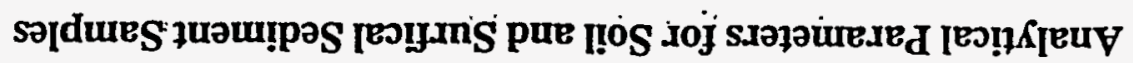

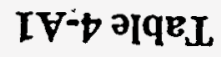

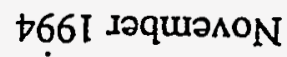

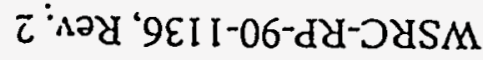

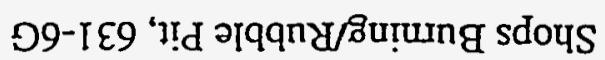

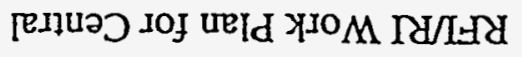


Table 4-A1

\section{Analytical Parameters for Soil and Surfical Sediment Samples}

\begin{tabular}{|c|c|c|c|c|c|c|}
\hline FACILITY & SAMPLE & SAMPLE & SAMPLE & SAMPLE & SAMPLE INT. & ANALYTE \\
\hline IDENTIFIER & \begin{tabular}{l|l|} 
PT & NUM \\
\end{tabular} & INSTRUMENT & TYPE & LOCATION & TOP |BOTTOM & CODE \\
\hline
\end{tabular}

\begin{tabular}{|c|c|c|c|c|c|c|c|c|}
\hline CS6G & 16 & 06 & Split-spoon & Soil & outside pit & 15.0 & 17.0 & 56 \\
\hline CS6G & .16 & $6 A$ & Split-spoon & Duplicate & outside pit & 15.0 & 17.0 & 56 \\
\hline CS6G & 16 & 07 & Split-spoon & Soil & outside pit & 20.0 & 22.0 & 56 \\
\hline CS6G & 16 & 08 & Split-spoon & Soil & outside pit & 25.0 & 27.0 & 56 \\
\hline CS6G & 16 & 09 & Split-spoon. & Soil & outside pit & 30.0 & 32.0 & 56 \\
\hline CS6G & 16 & 10 & Split-spoon & Soil & outside pit & 35.0 & 37.0 & 56 \\
\hline CS6G & 16 & 11. & Split-spoon & Soil & outside pit & 40.0 & 42.0 & 56 \\
\hline CS6G & 16 & 12 & Split-spoon & Soil & outside pit & 45.0 & 47.0 & 56 \\
\hline CS6G & 17 & 01 & Hand Auger & Soil & Surface outside pit $\neq$ & 0.0 & 1.0 & 123 \\
\hline CS6G & 17 & 02 & Hand Auger & Soil & Surface outside pit & 1.0 & 2.0 & $\cdot 123$ \\
\hline CS6G & 17 & 03 & Split-spoon & Șoil & outside pit & 2.0 & 4.0 & 123 \\
\hline CS6G & 17 & $3 A$ & Split-spoon & Duplicate & outside pit & 2.0 & 4.0 . & 123 \\
\hline CS6G & 17 & 04 & Split-spoon & Soil & outside pit & 5.0 & 7.0 & 123 \\
\hline CS6G & 17 & 05 & Split-spoon & Soil & outside pit & 10.0 & 12.0 & 123 \\
\hline CS6G & 17 & 06 & Split-spoon & . Soil & outside pit & 15.0 & 17.0 & 56 \\
\hline CS6G & 17 & .07 & Split-spoon & Soil & outside pit & 20.0 & 220 & 56 \\
\hline CS6G & 17 & 08 & Split-spoon & Soil & : outside pit & 25.0 & 27.0 & 56 \\
\hline CS6G & 17 & 09 & Split-spoon & Soil & outside pit & 30.0 & 32.0 & 56 \\
\hline CS6G & 17 & 10 & Split-spoon & Soil & outside pit & 35.0 & 37.0 & 56 \\
\hline CS6G & 17 & 11 & Split-spoon & Soil & outside pit & 40.0 & 42.0 & 56 \\
\hline CS6G & 17 & 12 & Split-spoon & Soil & outside pit & 45.0 & .47 .0 & 56. \\
\hline CS6G & 17 & $12 A$ & Split-spoon & Duplicate & - outside pit & 45.0 & -47.0 & 56 \\
\hline CS6G & 18 & 01 & Hand Auger & Soil & Background & 0.0 & 1.0 & 123 \\
\hline CS6G & 18 & 02 & Hand Auger & Soil & Background & 1.0 & 2.0 & 123 \\
\hline CS6G & 18 & 03 & Split-spoon & Soil & Background & 2.0 & 4.0 & 123 \\
\hline CS6G & 18 & $3 A$ & Split-spoon & Duplicate- & Background & .2 .0 & 4.0 & 123 \\
\hline CS6G & 18 & 04 & Split-spoon & Soil & Background & 5.0 & 7.0 & 123 \\
\hline CS6G & 18 & 05 & Split-spoon & Soil & Background & 10.0 & 12.0 & 123 \\
\hline CS6G & 18 & 06 & Split-spoon & Soil & Background & 15.0 & 17.0 & 56 \\
\hline CS6G & 18 & 07 & Split-spoon & Soil & Background & 20.0 & 22.0 & 56 \\
\hline $\mathrm{CS6G}$ & 18 & 08 & Split-spoon & Soil & Background & 25.0 & 27.0 & 56 \\
\hline CS6G & 18 & 09 & Split-spoon & Soil & Background & 30.0 & 32.0 & 56 \\
\hline CS6G & 18 & 10 & Split-spoon & Soil & Background & 35.0 & 37.0 & 56 \\
\hline CS6G & 18 & 11 & Split-spoon & Soil & Background & 40.0 & 42.0 & 56 \\
\hline $\mathrm{CS6G}$ & 18 & 12 & Split-spoon & Soil & Background & 45.0 & 47.0 & 56 \\
\hline CS6G & 18 & $12 \mathrm{~A}$ & Split-spoon & Duplicate & Background & 45.0 & 47.0 & 56 \\
\hline CS6G & 19 & 01 & Hand Auger & Soil & Background & 0.0 & 1.0 & 123 \\
\hline CS6G & 19 & 02 & Hand Auger & Soil & Background & 1.0 & 2.0 & 123 \\
\hline CS6G & 19 & 03 & Split-spoon & Soil & Background & 2.0 & 4.0 & 123 \\
\hline
\end{tabular}


RFI/RI Work Plan for Central

WSRC-RP-90-1136, Rev. 2

Shops Burning/Rubble Pit, 631-6G

November 1994

- Table 4-A1

\section{Analytical Parameters for Soil and Surfical Sediment Samples}

\begin{tabular}{|c|c|c|c|c|c|}
\hline \begin{tabular}{|l} 
FACILITY \\
IDFNTITIFE
\end{tabular} & \begin{tabular}{|l} 
SAMPLE \\
PT NUI
\end{tabular} & \begin{tabular}{|l|} 
SAMPLE \\
SANTRUMFNT
\end{tabular} & $\begin{array}{l}\text { SAMPLE } \\
\text { TYPF }\end{array}$ & SAMPLE & SAMPLE INT. : : ANALYTE \\
\hline
\end{tabular}

\begin{tabular}{|c|c|c|c|c|c|c|c|c|}
\hline CS6G & -19 & 04 & Split-spoon & $\cdots$ Soil $\cdots \cdots$ & Background $: \cdots$ & 5.0 & $7.0 \%$ & $\therefore 123$ \\
\hline CS6G & 19 & $04 \mathrm{~A}$ & Split-spoon & Duplicate & Background: - & 5.0 & 7.0 & 123 \\
\hline CS6G & 19 & 05 & Split-spoon & Soil & Background .: : & 10.0 & 12.0 & $\ldots 123$ \\
\hline CS6G & 19 & 06 & Split-spoon & Soil & Background & $15.0^{\circ}$ & 17.0 & $\therefore 56$ \\
\hline CS6G & 19 & 07 & Split-spoon & Soil & Background & 20.0 & 22.0 & 56 \\
\hline CS6G & 19 & 08 & Split-spoon & Soil & Background & 25.0 & 27.0 & 56 \\
\hline CS6G & 19 & 09 & Split-spoon & Soil & Background & 30.0 & 32.0 & 56 \\
\hline CS6G & 19 & 10 & Split-spoon & Soil & Background & 35.0 & 37.0 & 56 \\
\hline CS6G & 19 & 11 & Split-spoon & Soil & Background & 40.0 & 42.0 & 56 \\
\hline CS6G & 19 & 12 & Split-spoon & Soil & Background & 45.0 & 47.0 & 56 \\
\hline CS6G & 20 & 01 & Hand Auger . & Soil & Background & 0.0 & 1.0 & 123 \\
\hline CS6G & 20 & 02 & Hand Auger. & Soil & Background & 1.0 & 2.0 & 123 \\
\hline CS6G & 20 & 03 & Split-spoon & Soil & Background & 2.0 & 4.0 & 123 \\
\hline CS6G & 20 & 04 & Split-spoon & Soil & Background & 5.0 & 7.0 & 123. \\
\hline CS6G & 20 & .05 & Split-spoon & Soil & Background. & 10.0 & 12.0 & 123 \\
\hline CS6G & 20 & 06 & Split-spoon & Soil & Background & 15.0 & 17.0 & 56 \\
\hline CS6G & 20 & 07 & Split-spoon & Soil & Background & 20.0 & 22.0 & $\therefore 56$ \\
\hline CS6G & 20 & 08 & Split-spoon & Soil & Background & 25.0 & 27.0 & $\therefore 56$ \\
\hline CS6G & 20 & 09 & Split-spoon & Soil & Background & 30.0 & 32.0 & 56 \\
\hline CS6G & 20 & 10 & Split-spoon & Soil & Background & 35.0 & 37.0 & $\therefore .56$ \\
\hline CS6G & 20 & 11 & Split-spoon & Soil & Background & 40.0 & 42.0 & $\because 56$. \\
\hline CS6G & 20 & 12 & Split-spoon & Soil & Background & 45.0 & 47.0 & $\because \quad 56$ \\
\hline CS6G & 21 & 01 & Hand Auger & Soil & Background & 0.0 & 1.0 & 123 \\
\hline CS6G & 21 & 02 & Hand Auger & Soil & Background & 1.0 & 2.0 & 123 \\
\hline CS6G & 21 & 03 & Split-spoon & Soil & Background & 2.0 & 4.0 & 123 \\
\hline CS6G & 21 & 04 & Split-spoon & Soil & Background & 5.0 & 7.0 & 123 \\
\hline CS6G & 21 & 05 & Split-spoon & Soil & Background & 10.0 & 12.0 & 123 \\
\hline CS6G & 21 & 06 & Split-spoon & Soil & Background & 15.0 & 17.0 & 56 \\
\hline CS6G & 21 & $6 \mathrm{~A}$ & Split-spoon & Duplicate & Background & 15.0 & 17.0 & 56 \\
\hline CS6G & 21 & 07 & Split-spoon & Soil & Background & 20.0 & 22.0 & 56 \\
\hline CS6G. & 21 & 08 & Split-spoon & Soil & Background & 25.0 & 27.0 & 56 \\
\hline CS6G & 21 & 09 & Split-spoon & Soil. & Background & 30.0 & 32.0 & 56 \\
\hline CS6G & 21 & 10 & Split-spoon & Soil & Background & 35.0 & 37.0 & 56 \\
\hline CS6G & 21 & 11 & Split-spoon & Soil & Background & 40.0 & 42.0 & 56. \\
\hline CS6G & 21 & 12 & Split-spoon & Soil & Background & 45.0 & 47.0 & 56 \\
\hline CS6G & 22 & 01 & Hand Auger & Soil & Background & 0.0 & 1.0 & 123 \\
\hline CS6G & 22 & 02 & Hand Auger & Soil & Background & 1.0 & 2.0 & 123 \\
\hline CS6G & 22 & 03 & Split-spoon & Soil & Background & 2.0 & 4.0 & 123 \\
\hline CS6G & 22 & 04 & Split-spoon & Soil & Background & 5.0 & 7.0 & 123 \\
\hline
\end{tabular}

Addendum Page 4-A8 of 12 


\section{Table 4-A1}

\section{Analytical Parameters for Soil and Surfical Sediment Samples}

\begin{tabular}{|c|c|c|c|c|c|c|}
\hline FACILITY & SAMPLE & SAMPLE & SAMPLE & SAMPLE. & SAMPLE INT. & ANALYTE \\
\hline IDENTIFIEA & PT INUM INSTRUMENT & TYPE & LOCATION & TOP BOTTOM .... CODE \\
\hline
\end{tabular}

\begin{tabular}{|c|c|c|c|c|c|c|c|c|}
\hline CS6G & 22 & 04A & Split-spoon & Duplicate & Background & 5.0 & 7.0 & 123 \\
\hline CS6G & 22 & 05 & Split-spoon & Soil & - Background & 10.0 & 12.0 & 123 \\
\hline CS6G & 22 & 06 & Split-spoon & Soil & Background & 15.0 & 17.0 & 56 \\
\hline CS6G & 22 & 07 & Split-spoon & Soil & Background & 20.0 & 22.0 & 56 \\
\hline CS6G & 22 & 08 & Split-spoon & Soil & Background & 25.0 & 27.0 & 56 \\
\hline CS6G & 22 & 09 & Split-spoon & Soil & Background & 30.0 & 32.0 & 56 \\
\hline CS6G & 22 & 10 & Split-spoon & Soil & Background & 35.0 & 37.0 & 56 \\
\hline CS6G & 22 & 11 & Split-spoon & Soil & Background & 40.0 & 42.0 & 56 \\
\hline CS6G & 22 & 12 & Split-spoon & Soil & Background & 45.0 & 47.0 & 56 \\
\hline CS6G & 23 & 01 & Hand Auger & Soil & R:R. Ditch - Downgradient & & & 123 \\
\hline CS6G & 24 & 01 & Hand Auger & Soil & R.R. Ditch - Downgradient & & & 123 \\
\hline CS6G & 25 & 01 & Hand Auger & Soil & P.R. Ditch - Downgradient & & & 123 \\
\hline CS6G & 26 & 01 & Hand Auger. & Soil & R.R. Ditch - Upgradient & & & 123 \\
\hline CS6G & 27 & 01 & Hand Auger & Soil & R.R. Ditch - Upgradient & & & 123 \\
\hline CS6G & 28 & 01 & Hand Auger & Soil & R.R. Ditch - Upgradient & & & 123 \\
\hline CS6G & 28 & $01 \mathrm{~A}$ & Hand Auger & Duplicate & R.R. Ditch - Upgradient & & & 123 \\
\hline CS6G & TB & 01 & & Trip Blank & Cooler 1 & & & 7 \\
\hline CS6G & $T B$ & 02 & & Trip Blank & Cooler 2 & & & 7 \\
\hline CS6G & TB & 03 & & Trip Blank & Cooler 3 & & $\therefore$ & 7 \\
\hline CS6G & TB & 04 & & Trip Blank & Cooler 4 & & & 7 \\
\hline CS6G: & TB & 05 & & Trip Blank & Cooler 5 & & & 7 \\
\hline CS6G & $T B$ & 06 & & Trip Blank & Cooler 6 & & & 7 \\
\hline CS6G & TB & 07 & & Trip Blank & Cooler 7 & & & 7 \\
\hline CS6G & FB & 01 & & Field Blank & Day 1 & & & 123 \\
\hline CS6G & $\mathrm{FB}$ & 02 & & Field Blank & Day 2 & & & 123 \\
\hline CS6G & FB & 03 & & Field Blank & Day 3 & & & 123 \\
\hline CS6G & FB & 04 & & Field Blank & Day 4 & & & 123 \\
\hline CS6G & $F B$ & 05 & & Field Blank & Day 5 & & & 123 \\
\hline CS6G & FB & 06 & & Field Blank & Day 6 & & & 123 \\
\hline CS6G & FB & 07 & & Field Blank & Day 7 & & & 123 \\
\hline CS6G & RA & 01 & & Rinsate (A) & Day 1 & & & 123 \\
\hline CS6G & $\mathrm{RB}$ & 01 & & Rinsate (S) & Day 1 & & & 123 \\
\hline CS6G & RA & 02 & & Rinsate (A) & Day 2 & & & 123 \\
\hline CS6G & $\mathrm{RB}$ & 02 & & Rinsate (S) & Day2 & & & 123 \\
\hline CS6G & $\mathrm{RA}$ & 03 & & Rinsate (A) & Day 3 & & & 123 \\
\hline CS6G & $\mathrm{RB}$ & 03 & & Rinsate (S) & Day 3 & & & 123 \\
\hline CS6G & $\mathrm{RA}$ & 04 & & Rinsate (A) & Day 4 & & & 123 \\
\hline CS6G & $\mathrm{AB}$ & 04 & & Rinsate $(S)$ & Day 4 & & & 123 \\
\hline
\end{tabular}


Table 4-A1

\section{$\therefore:$ : Analytical Parameters for Soil and Surfical Sediment Samples}

\begin{tabular}{|c|c|c|c|c|c|c|c|}
\hline \multirow{2}{*}{\begin{tabular}{|c|} 
FACILITY \\
IDENTIFIER
\end{tabular}} & \multicolumn{2}{|c|}{ SAMPLE } & SAMPLE ... & SAMPLE & $\therefore \quad$ SAMPLE & SAMPLE INT. & \multirow{2}{*}{$\begin{array}{c}\text { ANALYTE } \\
\text { CODE }\end{array}$} \\
\hline & PT: & NUM & INSTRUMENT: & $\because$ TYPE & $\because \because:$ LOCATION $:$ & \begin{tabular}{l|l|} 
TOP & BOTTOM \\
\end{tabular} & \\
\hline CS6G" & $\mathrm{RA}$ & 05 & & Rinsate (A) & Day 5 & & 123 \\
\hline CS6G & $\mathrm{RB}$ & 05 & $\therefore$ & Rinsate (S) & Day 5 & $\therefore$ & 123 \\
\hline CS6G: & $R A$ & 06 & $\therefore$ & Rinsate (A) & Day 6. & 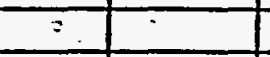 & 123 \\
\hline CS6G & $R B$ & 06 & & Rinsate (S) & Day 6 & & 123 \\
\hline CS6G & $R A$ & 07 & & Rinsate (A) & Day 7 & & 123 \\
\hline CS6G & $R A$ & 07 & & Rinsate (S) & Day 7 & & 123 \\
\hline
\end{tabular}

Sample Pt Column

TB Trip Blank

$\dot{F B}$ Field Blank

RA Rinsate - Auger

RB Rinsate - Splitspoon

\section{Sample Num Column}

A Duplicate

B Split ( $10 \%$ splits will be added if necessary).

\section{Analyte Codes}

1 - TCLTAL W/TIC

$$
5 \text { - GCMS VOCs }
$$

2 - Dioxins/Furans

6 - RCRA Metals

3-Rad Indicators

$$
\text { 7- TCL VOCs only }
$$

Notes

$$
\begin{aligned}
(A) & =\text { Auger } \\
(S) & =\text { Splitspoon } \\
\text { BOP } & =\text { Bottom of Pit } \\
\text { bls } & =\text { Below Land Surface }
\end{aligned}
$$

* Sample interval (in $\mathrm{ft}$ bls) to be determined from BOP depth

- Sampling will be terminated $1-5 \mathrm{ft}$ BOP (inside pit) or $12 \mathrm{ft}$ bls (outside pit) if VOC field screening indicates two consequtive samples with no contamination

$\neq$ If the BOP is discovered, sampling will follow same intervals as inside pit .

$\triangle$ Samples will be collected in $5 \mathrm{ft}$ intervals until BOP is found 
Table 4-A2

Analytical Parameters for Surface Water and Sediment Samples

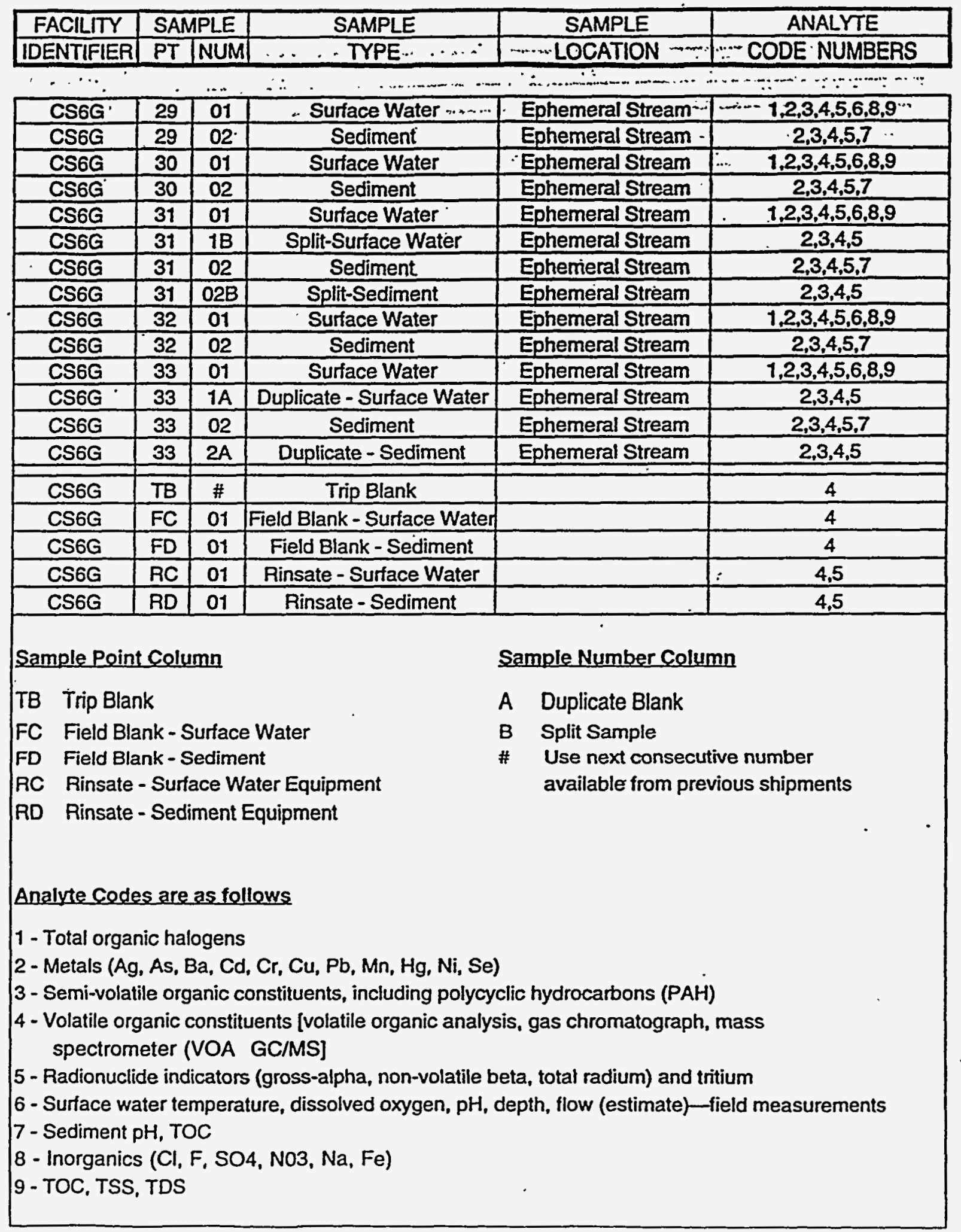




\section{Table 4-A3}

\section{Analytical Parameters for Groundwater Samples}

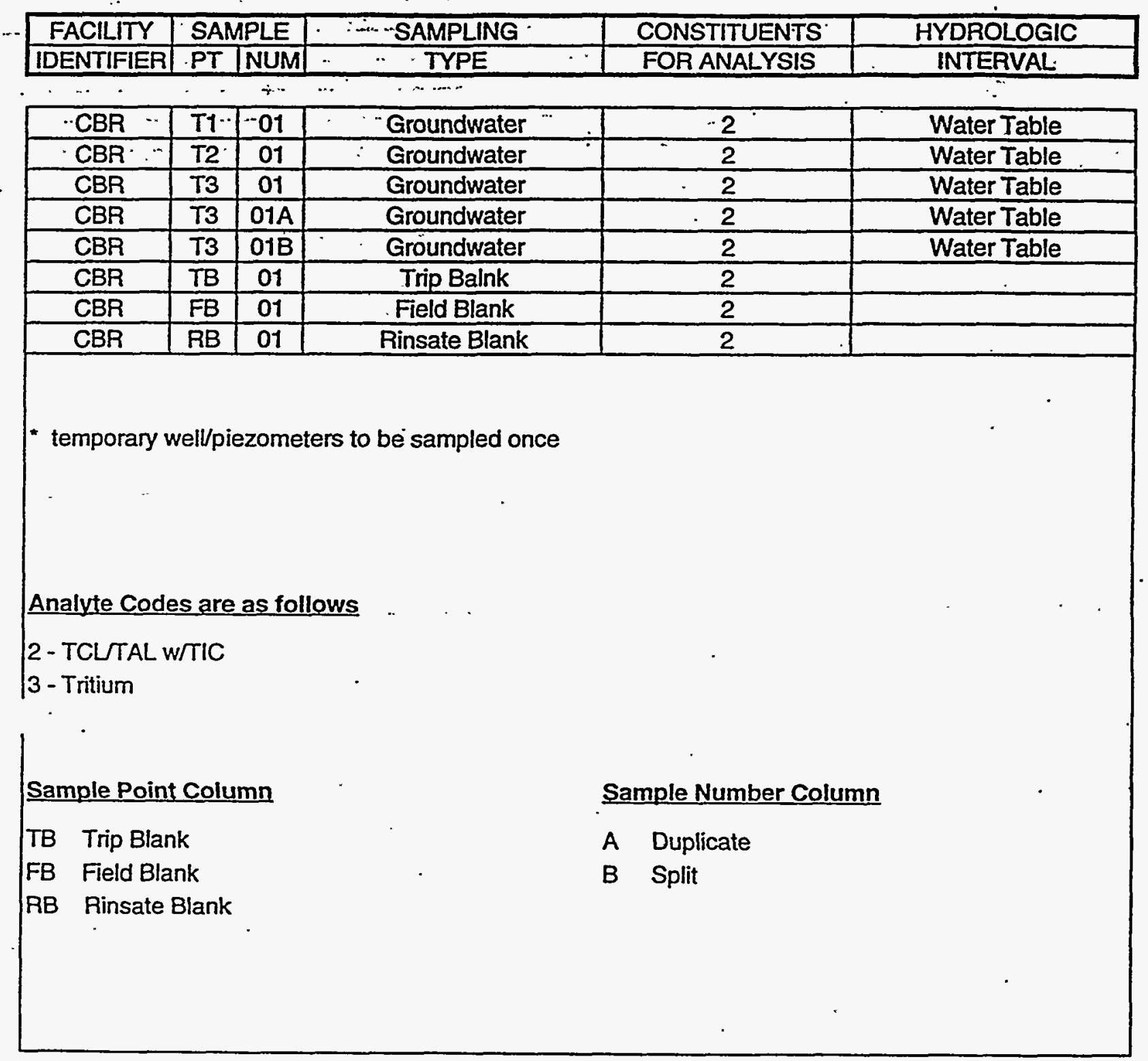


$\because \ldots \quad \ldots \quad$ Appendix B $\cdots$

\section{Daily Field Logs}


$K H \quad \approx 48 \%$ CLEAR

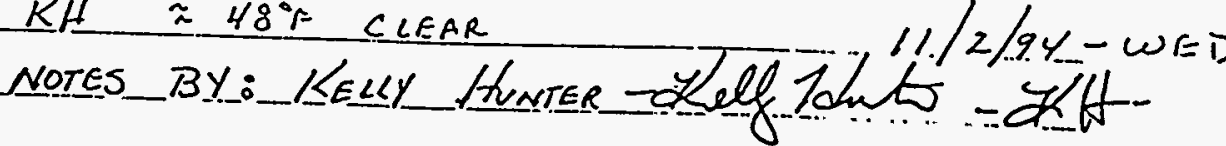

$7: 20$-@WEL BWILDINF - WAITING ON DRILS CREW 2550 - SPOKE $\omega /$ Tanelle Tanson w/wsRc - V.onelle CALLD THE DRIL CREW - THEY (THE DRTLL SREW) DED NOT KNOW OF THE PROTECT. IT WILL: TALE $\approx 2$ HOURS TO COLLET TAFE TOOLS ANO SHOW UP ON SITE - TRYED TO- CALL DAVED CLARK TO LET HIM KNOW:

8:35 - DAVID Clark AND RAY PLUNKETIQ WEL BUILDING - WE WENT OVER SCOPE E PROTECT DEIAFLS

8:50 - DAKLD CLARK \& RAY PLKNKETI LEFT STIE TO RETURN Q 10:00 UIEA OF DRILL CREW. T10:00 DRIL CREWLWEL 10:45 - ON SITE - DAVID CLARK \& RAY PLUNKET ON SITE ALSO DOE REPRESENJATIVE 11:05 - WENT OUER HAS PLAN WLALC_WIHO WERE IN ATENDDANCE1\%:10 - CHECKED OSHA TRAINING CERTIFISATES FOR AUL DRELCTNG SUB EMPLOYEES CHECKEO -OK.

- MOBED TO CBR-6 LOCATION PLACED PLASTIKS IN PROPOSED LOCATEON

$11: 22-C A L F B R A T E D$ HN AH:ZZ - PRILLES BEGIN SETUR FOR DRILLING 11:30 - DRILLERS LEFT SITE TO GET TIHE WWAER TRMCK FOR MUD ROTARYY 11:30 - Tanelle Janson ON SIrE 12:00 - Vandle Vanson LGeT Sistr. 12:05-, RAY PLUNKETI 12:15 - DAVE CLARK \&I RECON ACCESS... TO $C B R-6$

$12: 38$ - DRFCLERS BACK ON SITE W/. WATER $13: 15$ TRUCK. DRILLERS DON!T HAVE BARREER ROPE - LEET SETE .. TO . RETRIEVE 


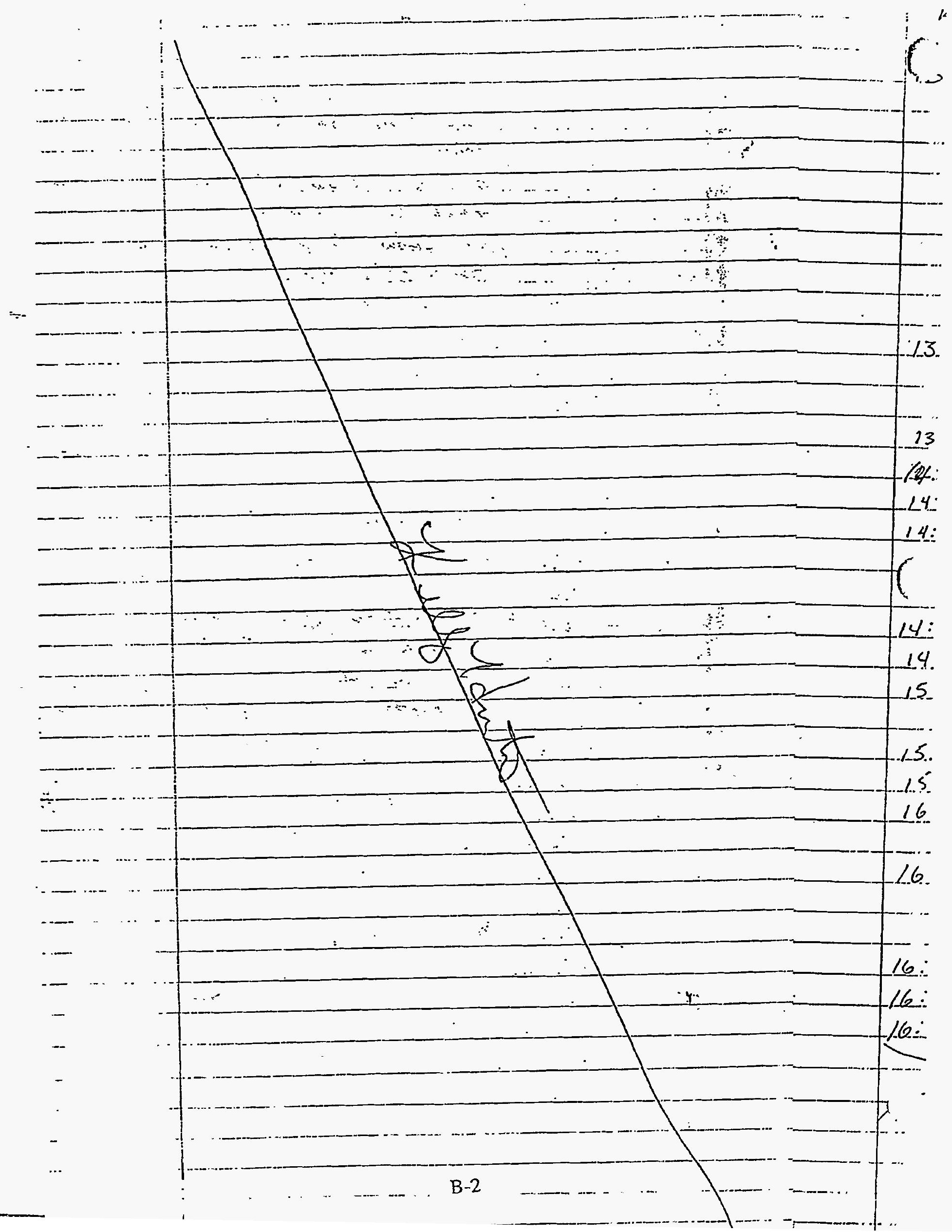


$1 \leq H \quad 1.1 / 2 / 94 \quad$ QLEAL____6. $6 \%$

13:30 - DRILLR HELPERS SETINK OP RIG

- measurementes.

$7 \%$ MUD Botrat BIT

$B I T \&$ TwO SUBS - $3.0^{\prime}$

MEASURED THREE TRORS Q $20^{\prime} .00$

$13: 47$ - Begad DetecING - CBR-06

- cHECKeD NOISE leves ARDUND THE RE

THE HAGHEST LEVEC wAS BZZ dBu.

$13: 55$ - CHECKED BREAIH ING ZONE WIIH HNU $\Phi$. PPM AJi:OS - MEASURER THREE RODS -

14:10 - DRELLER SHOWED BACK UPC SITE

14:15 - HOOKED UP THE DESANDER \& STARTED. UP - I CLASSIEFED SOTL TOBE A

course-mied silty- SAND

$14: 25$ - ADDING A.DRTLC ROD - 20.00́BGS

14:37 - Begdn Dillin Aydia

$15: 30$ - PEA Grayel \& CLAY ClOGED up DE-SANDER PUMP - TRYING TO RENouE OBSTRuCTIOAS =

$15: 39$ - REMOVER OBsTevetzon -

$15: 42$ - ADDZNG OAL ANOTHER DREL ROD:

$16: 02$ - BORING TERMIXIED Q $61.0^{\circ}$ BGS

$3+20+20+18 \Rightarrow 61.0^{\prime} \mathrm{BGS}$

16:05 - CIRCuLATIKG MUD DO CLEAN OUT BORZNT - IT APPEARS TO BE IN Clay

16:05 - DAVID CLARK LEET SZTE

$16: 20$ - DRILCES D TRLP OWT RODS

16:30- LEFT SITE FOX WELS BUTCDINT7
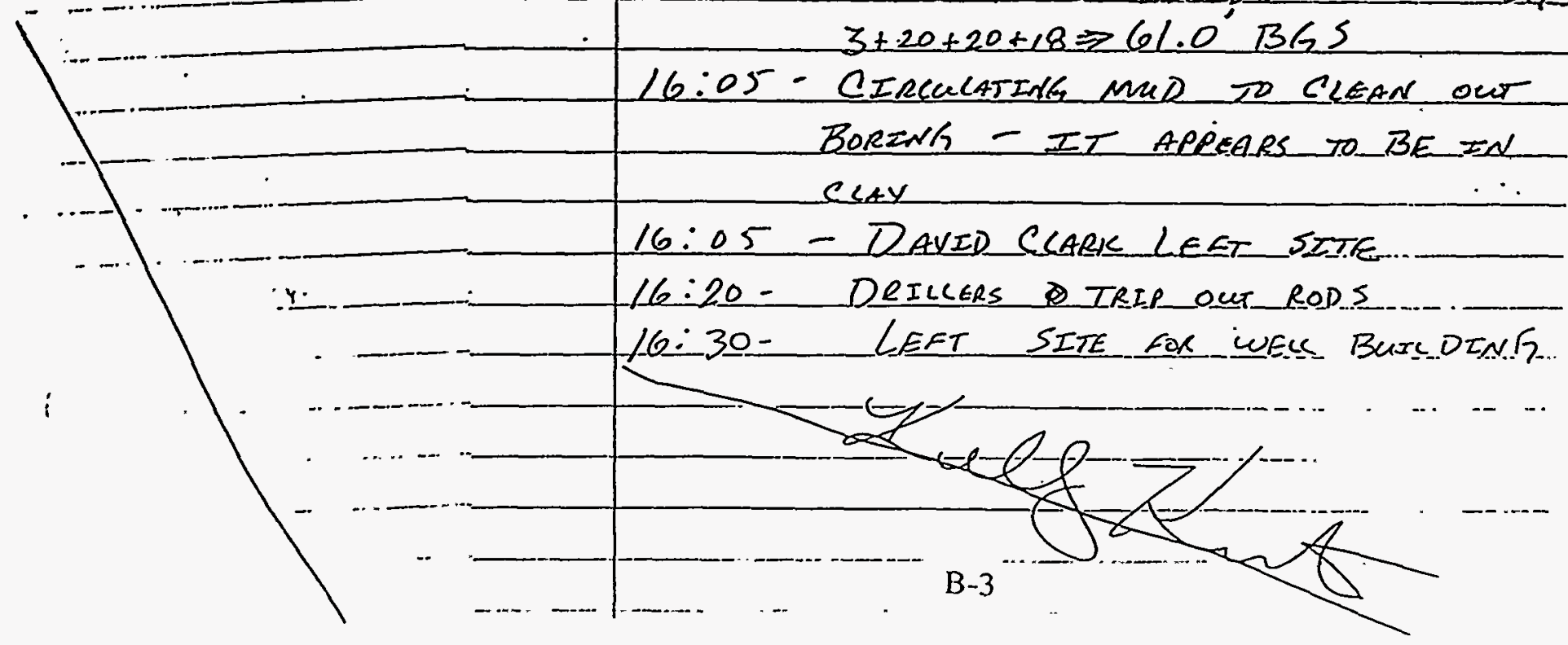


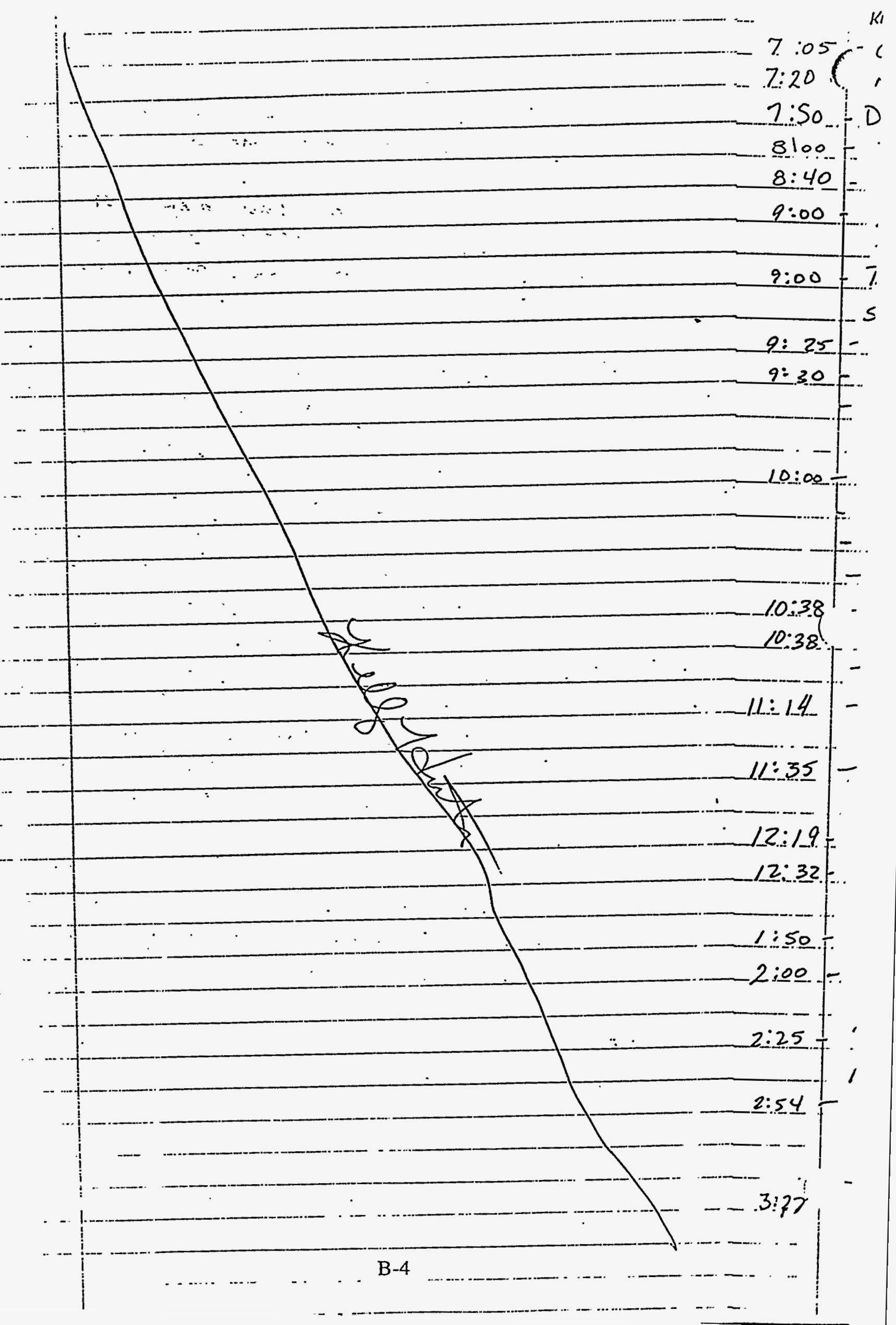


$11 / 3 / 94 \quad K H \quad$ CLEAR $\approx 78^{\circ} \mathrm{E}$

A:00 - SCREEN USED 0.016" SCOTIED

(2) $1 e^{\prime}$ 'SECTIZONS - SEE WELL CONSTRUCTEON/MAIERLAC. INEQRMATTONA FORMS EOR MEAUUREMENTS OA MATL. ETC.

4:45. FINISHED SETIING WELL - PREPARE FOR MOBE TO $C B R-O Y$ LOCATION TN TAE MORN INLG

5:00- LEET SETE FON WELC BUILDING

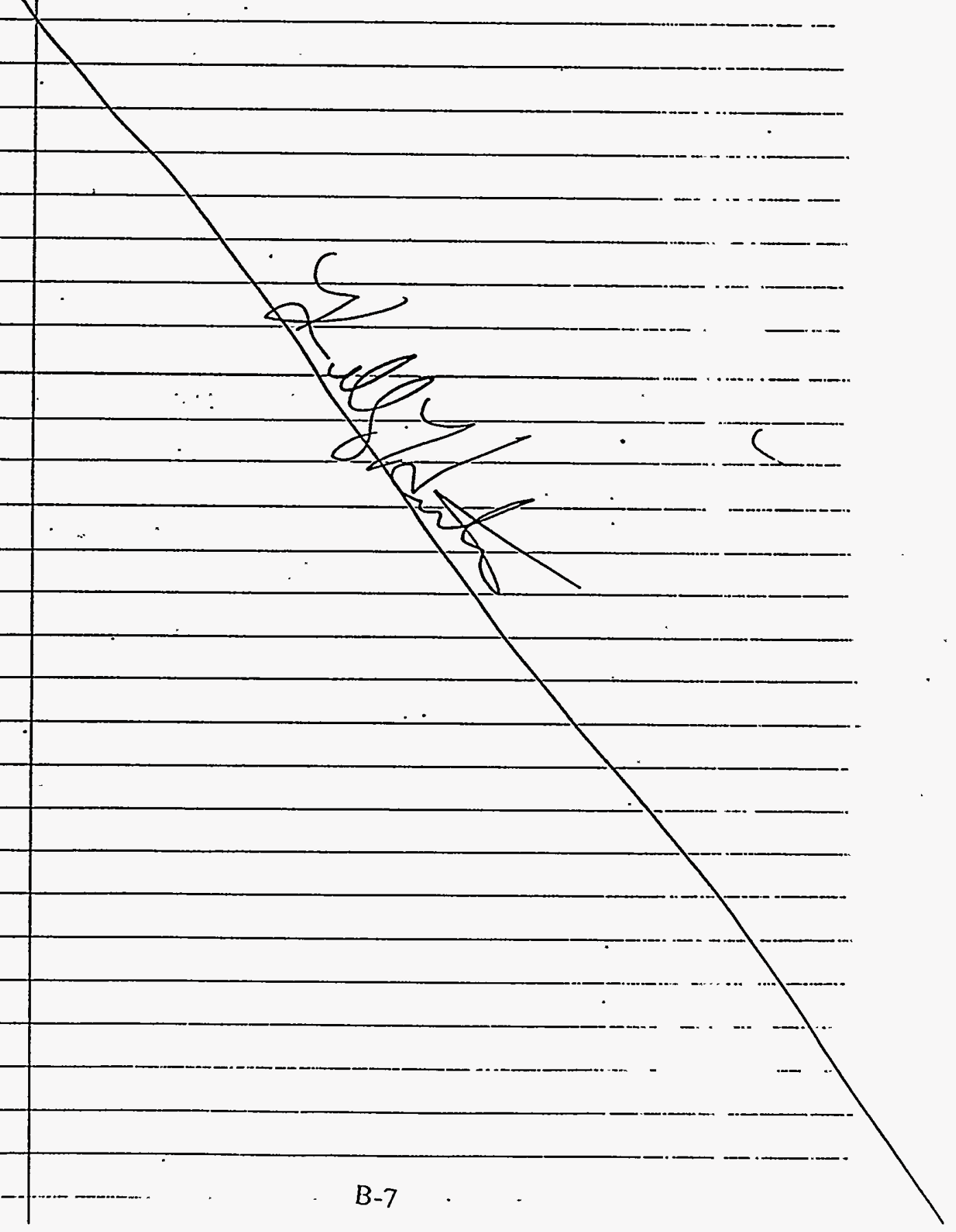




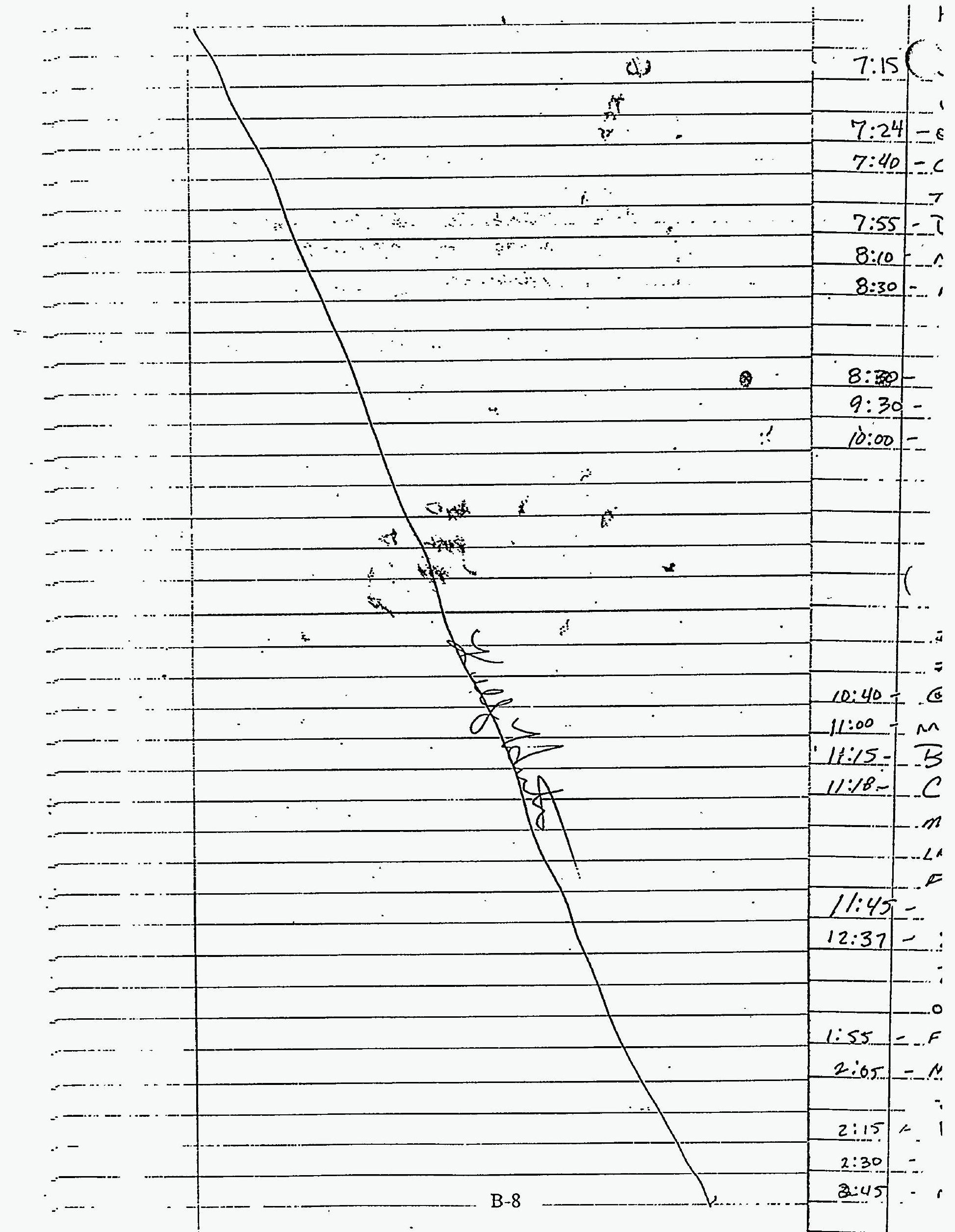


KH ClEAR $\approx 70^{\circ} \mathrm{F}-11 / 4 / 94$

7:15 - @ WELL BUILDING TO PSCKUP TWO WAY RANIO

7:24 -ON SITEF WAETLNG ONC DRLLLERS

7:40 - CHECKED WATER LEVEL IN CBR-06 - 49.72 FROM TOP OF CASTNG

7:55- DRTLLES ON SITE-DEWNED ERMT= Hesterdy EVenENG 8:10 MOBED TO CBR-O4

8:30 - NEW DRTCLER ON SITE - WENT OURR HES PLAN - WITHA C. BALEY - NOTE: CHECKED. HIS OSHA IRAXNING CERTIECATES - ACL IN ORDER

Q 8:3D - RIG SET UP FRR WEL ENSTALATION E CBR-OH $9: 30$ - BEGANL DetLCTLí

$10: 00$ - THE OVA WN CEET ON OVEE NIGHT AND THE BATERY ES DEAD. I CHECKED WIXTH THE TREL CKEW ANDD TOLD THEM TF THEY

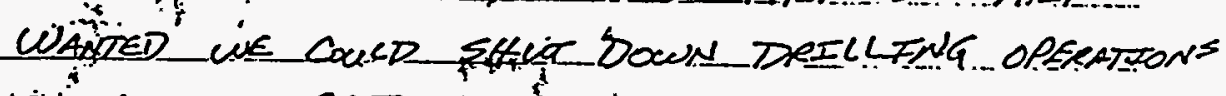
WUE WE GET A WEW OXA - THEY SAED. IT WAS NDT NECESARY DO SHOT DOWAI BUT

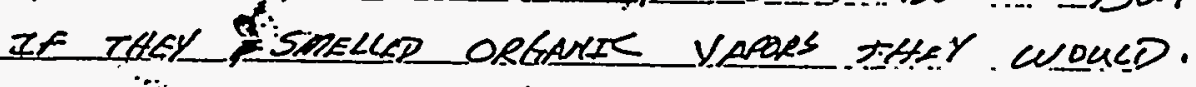
$\because$

$10: 40-Q \approx 42^{\prime}$ - CHANGING RODS (ADDFNG ZO' SESTOOA)

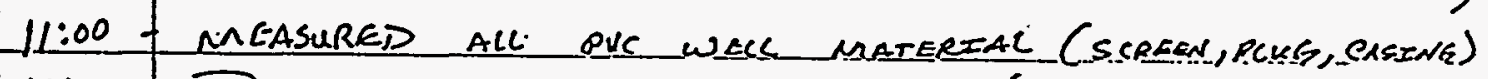

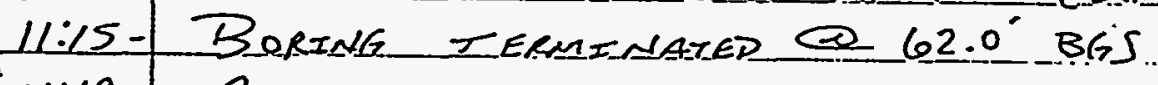

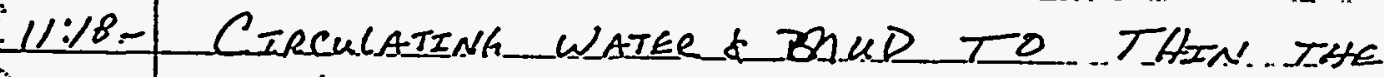
MUD SO SAND WrLl FACL - ALSO WATER T Teuck LEET TO REFICL EOR TRIMMIE OE SENRP A $B E A T D$ FOR: WELL CONSTRUCTEON

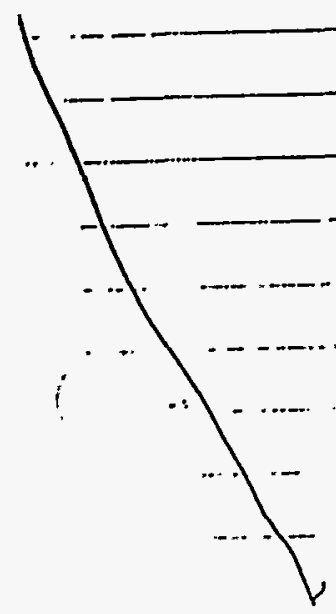

WATER TRUCK BACK ON SITE.

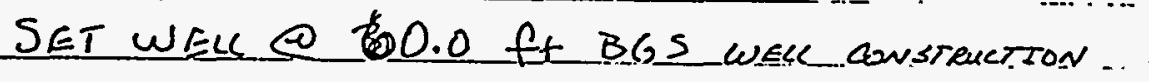

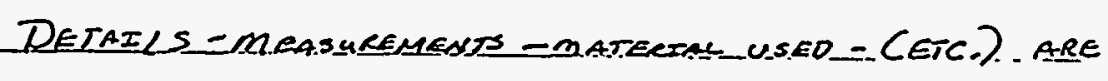
ON THE_WELL CONSTRUCTION DFAGRAM T. TACLY SHETT.

$1: 55$ - FENESHED SETTING CBR $=04$ 2:05 - MOPE TO-CB.R=OG TO GROUT T0. GROUND Táresce

$2: 15$ - BEGANE MEXING GROUT ...TYPE 1 CEMENT PORTLAND 2:30 - GROUTED TO GRONDD SUREACE_- SROUT $13.2 .(6 / \mathrm{gd})$ 2.45 - MOBED TO CRB:OS WITH THEE SAME GROUT/REMATARAR To Grout to Ground surates 


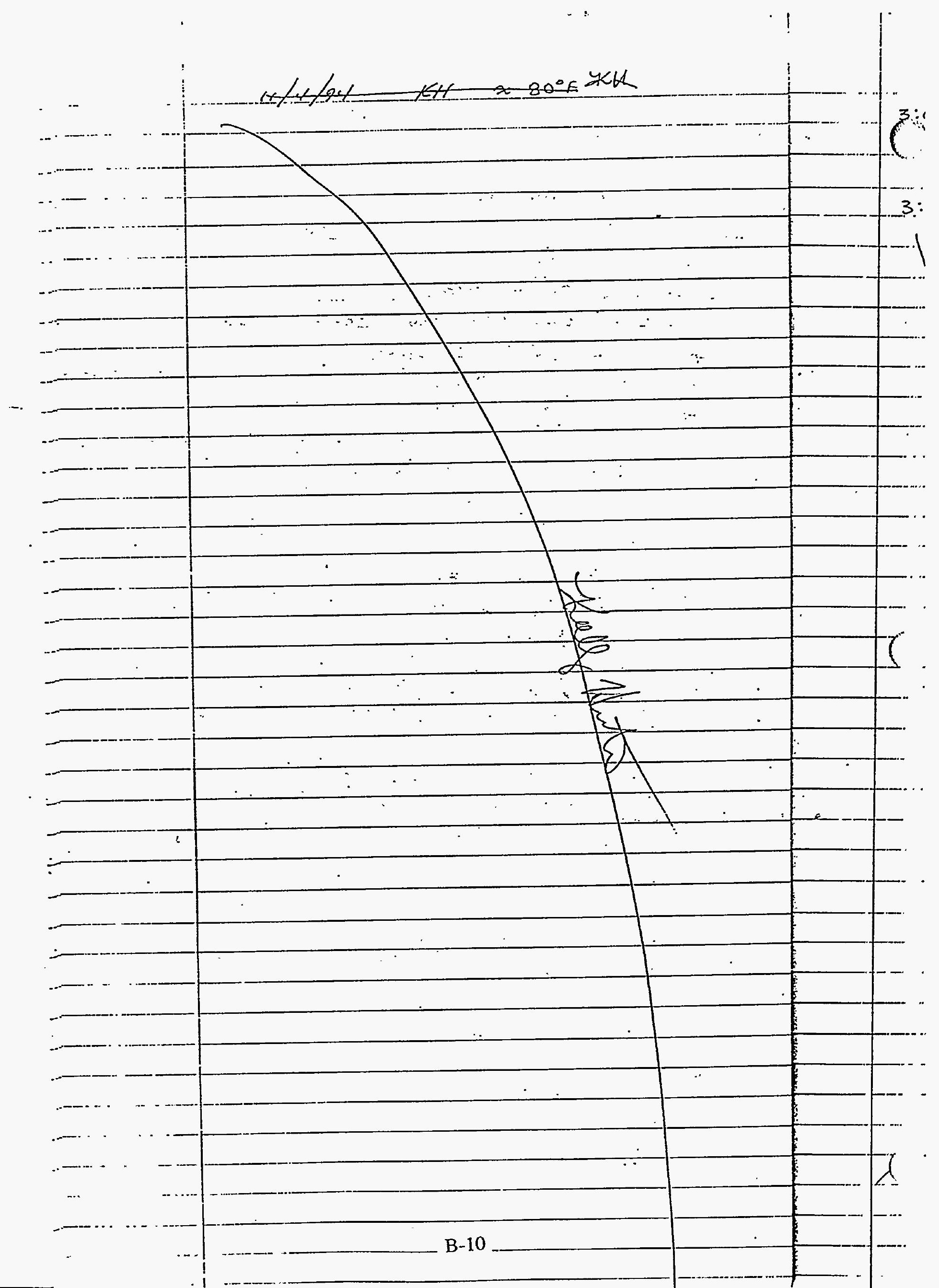


:E XKb

$Y$

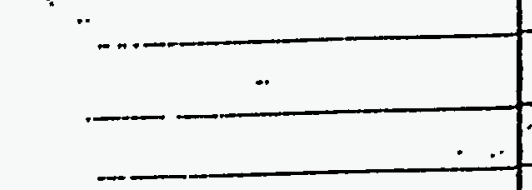

$B$

.

$-$

-

$11 / 4 / 94$ KH $\approx 80 \%$ CLEAR

3:00 - CONOETER TRIMMEE PTPE PUMPEO REMAINDCR OF. 13.2 MAN $3: 30-m I X E D$ ANOTI+ER. GROUT MIX $13.4 \mathrm{lb} / \mathrm{g} d$ GroutED to SURFACE

3:5O - LEFT SITEFOR WELL BUILPING

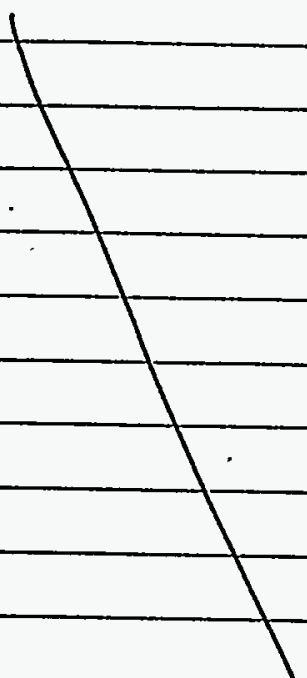

B-11 


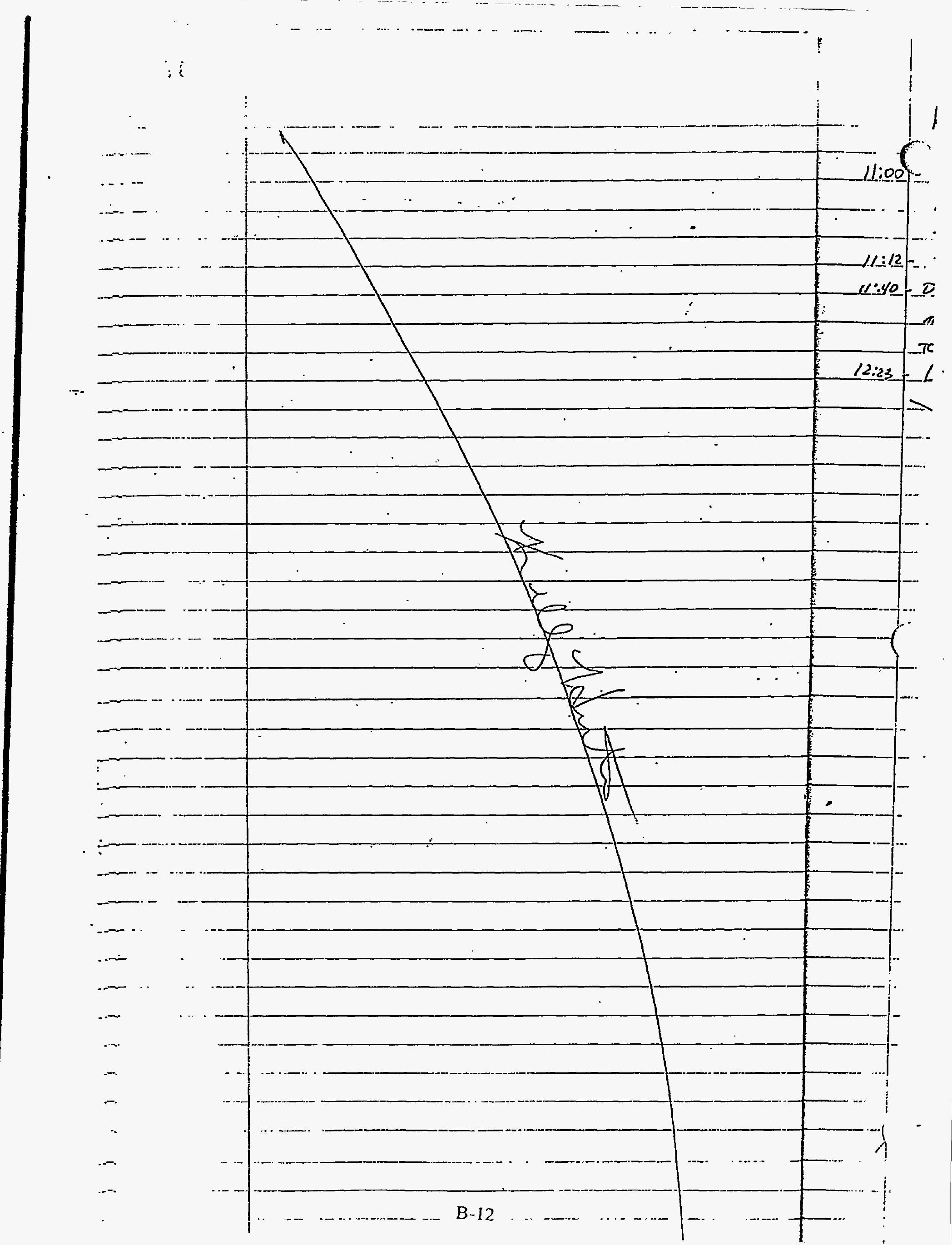


KH .... . $11 / 2 / 9.4 . . C L E A R \approx 30^{\circ} \mathrm{F}$.

11:00 - ON SIIE TO OVERSEE GROUTING OF CBR-4 -.. MEASURED TOP OF BENTONITE C $18.9^{\prime}=-70 \angle D$ DRILCERS TO GET A SIDE DISCHAREE PIPE TO GROUTT TO SURARCE ... $1 /: 12$ - DRILLERS LEET_SETX TO GET STDE. DISCHARGE. CONECTZON,

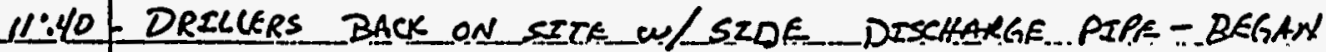

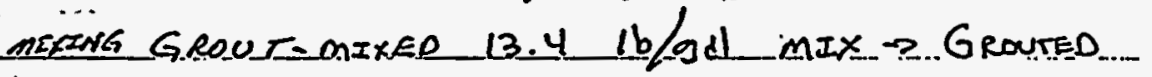
To Groukd Surface.

12:23 LEET SITE

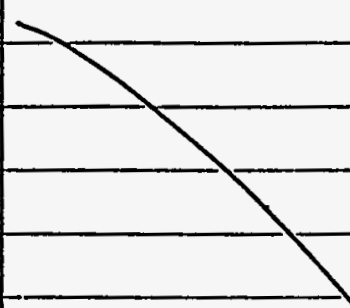




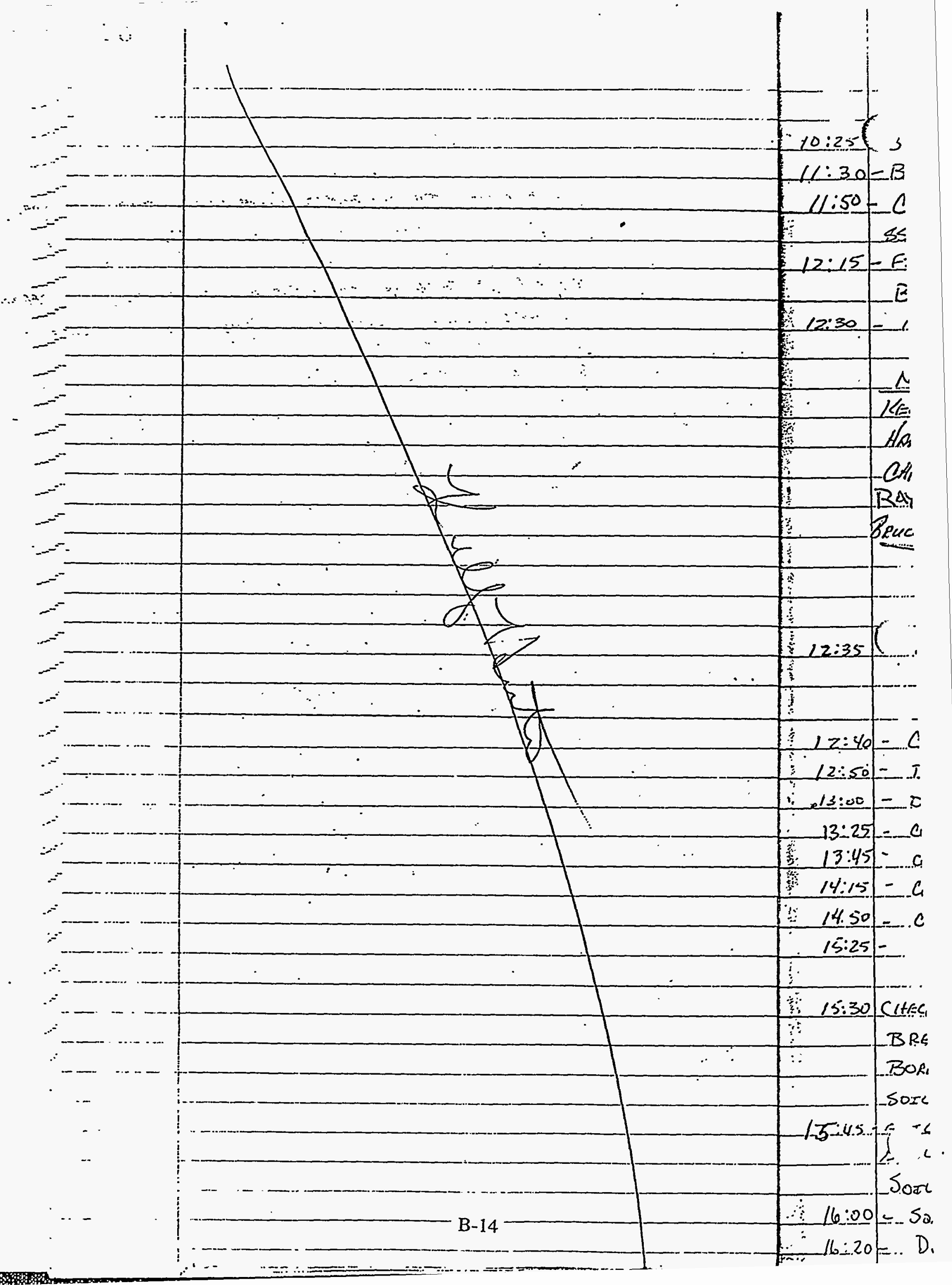




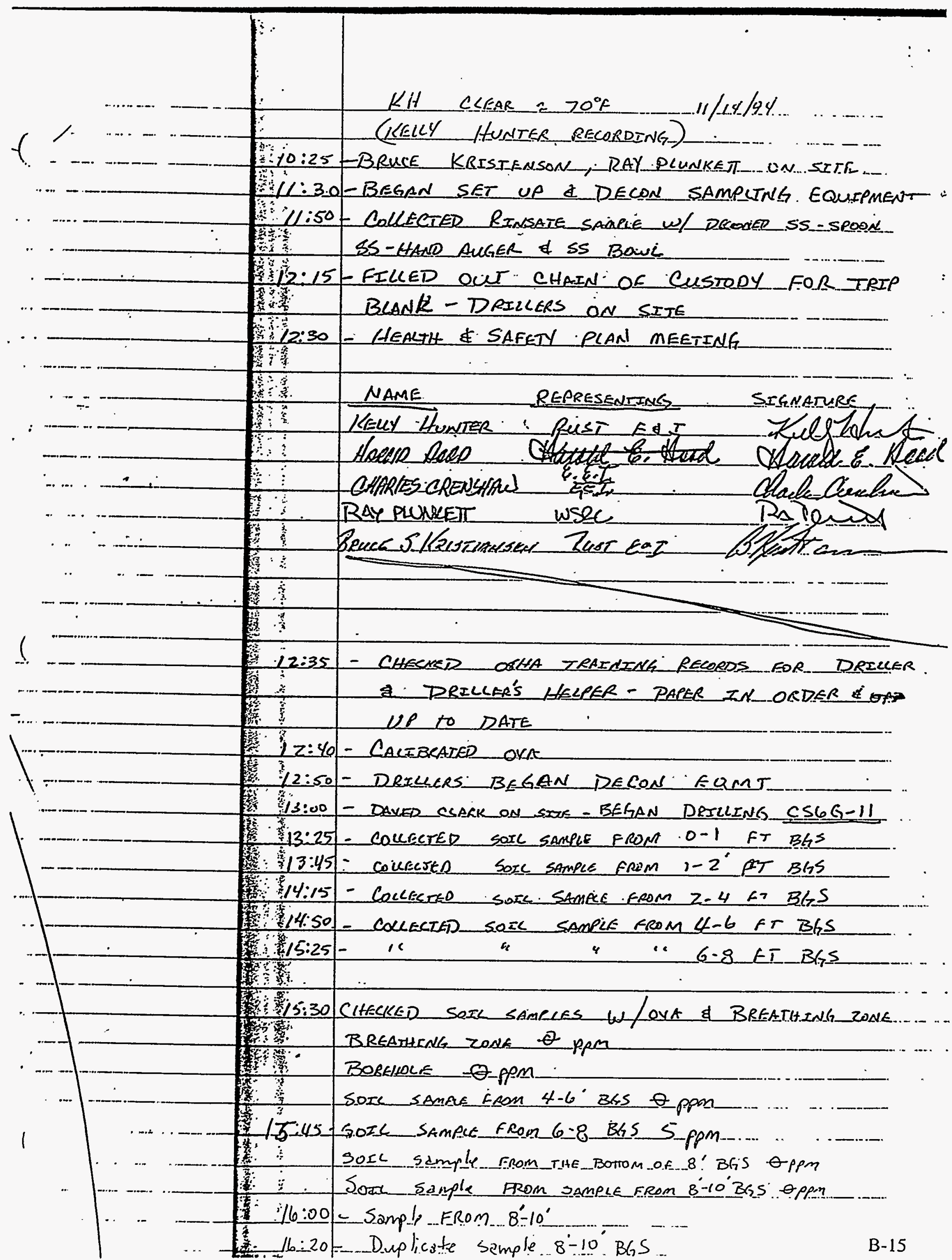




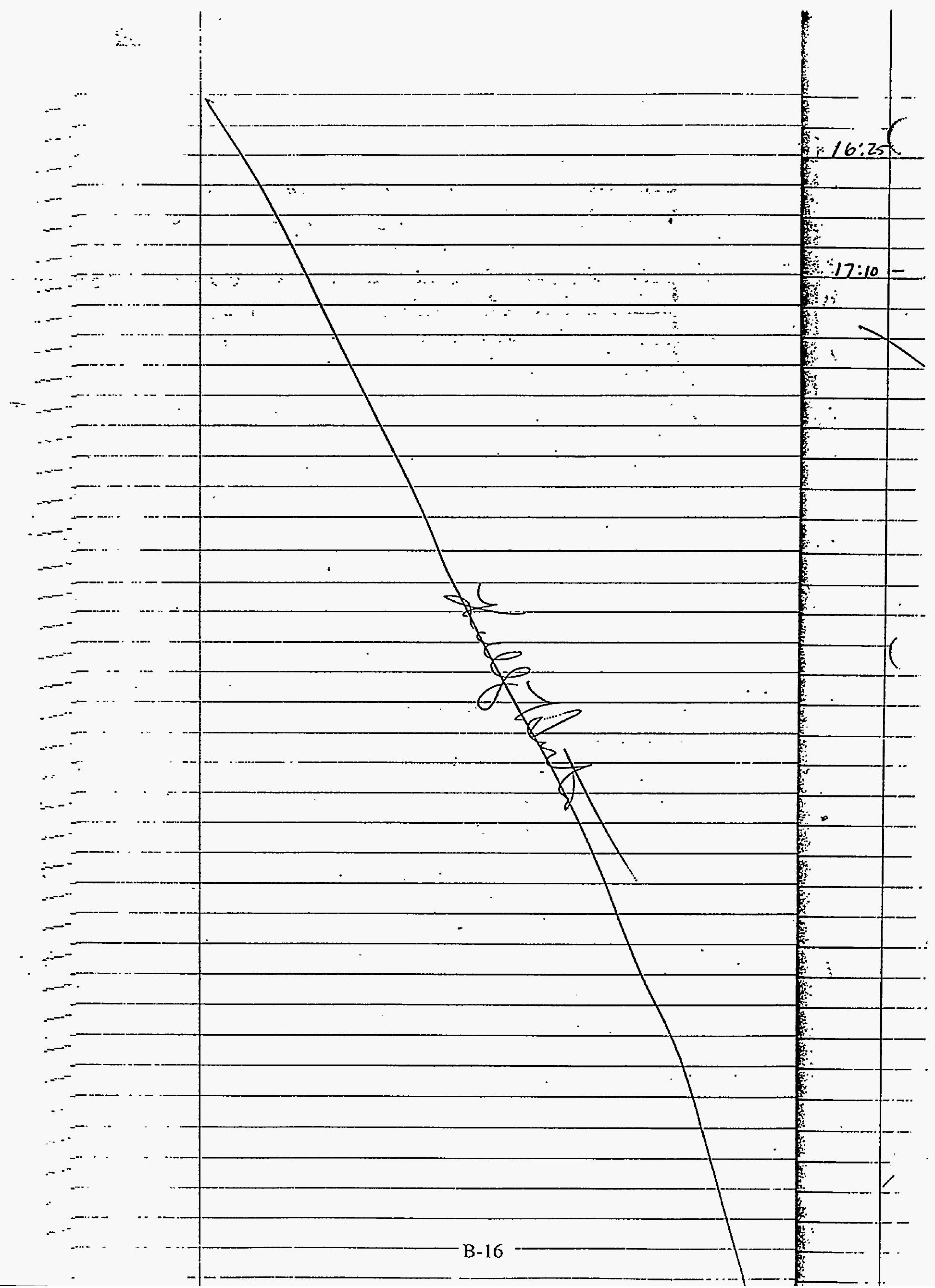




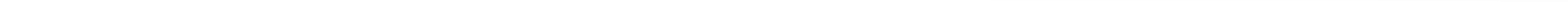




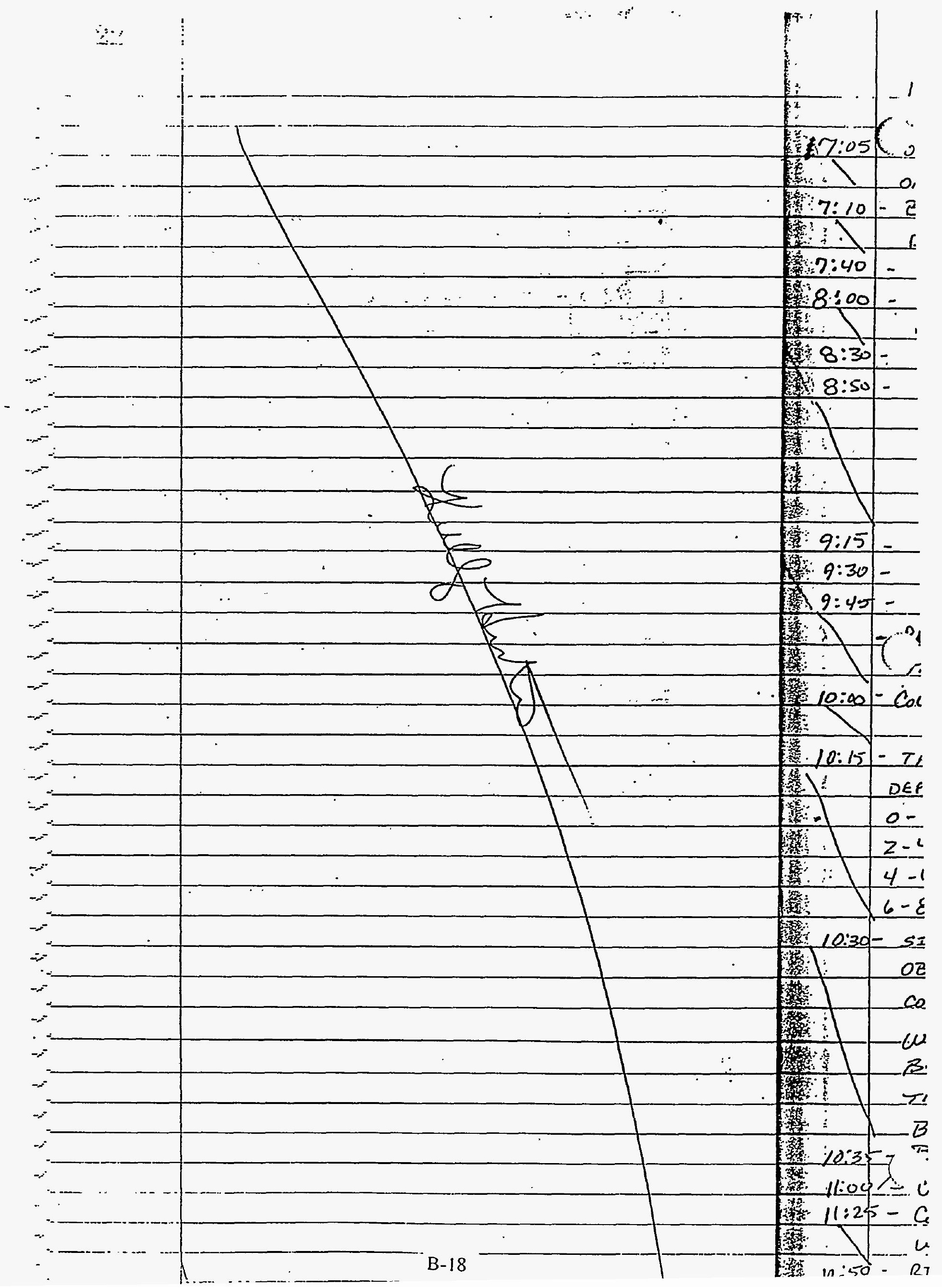




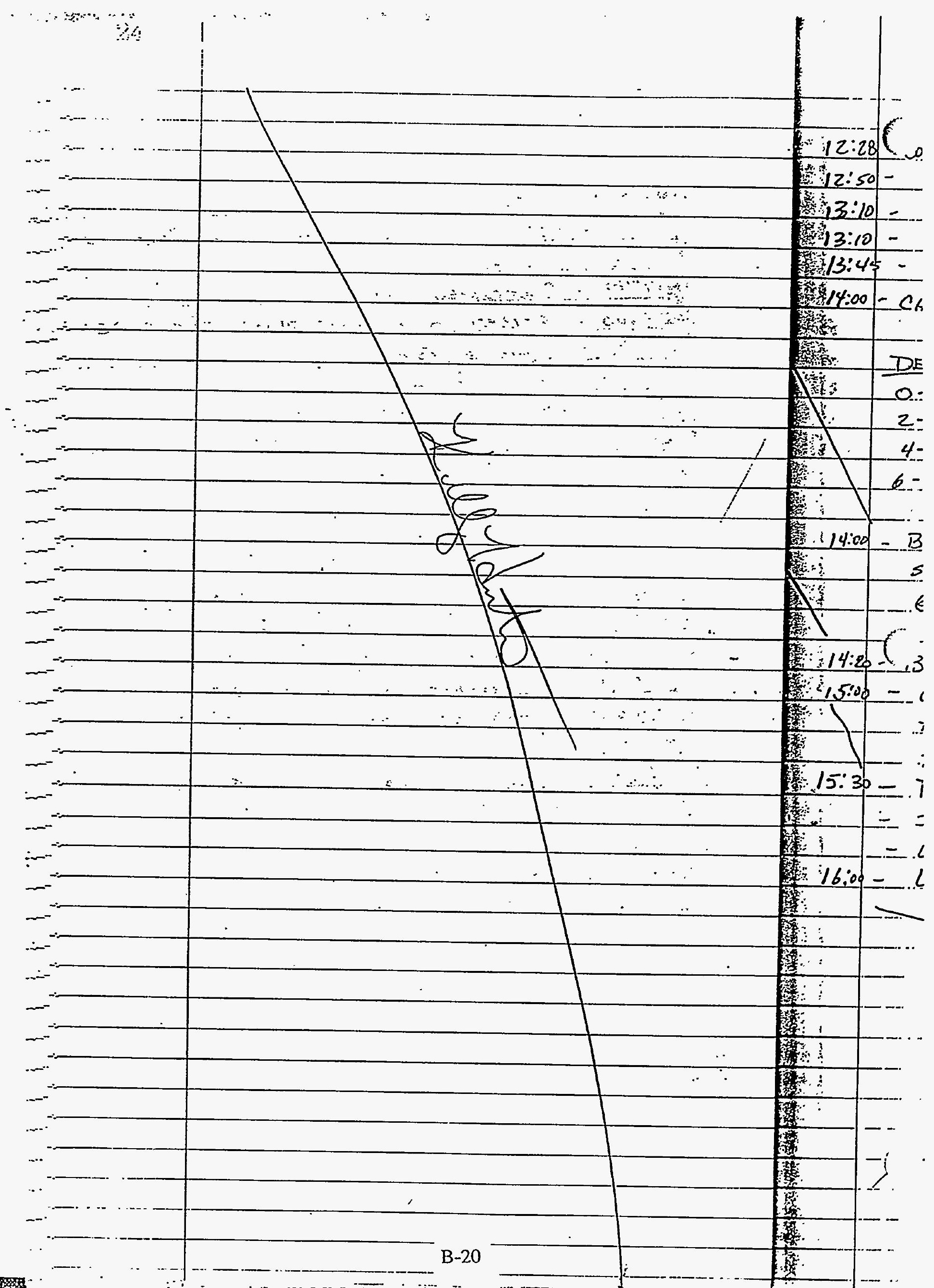




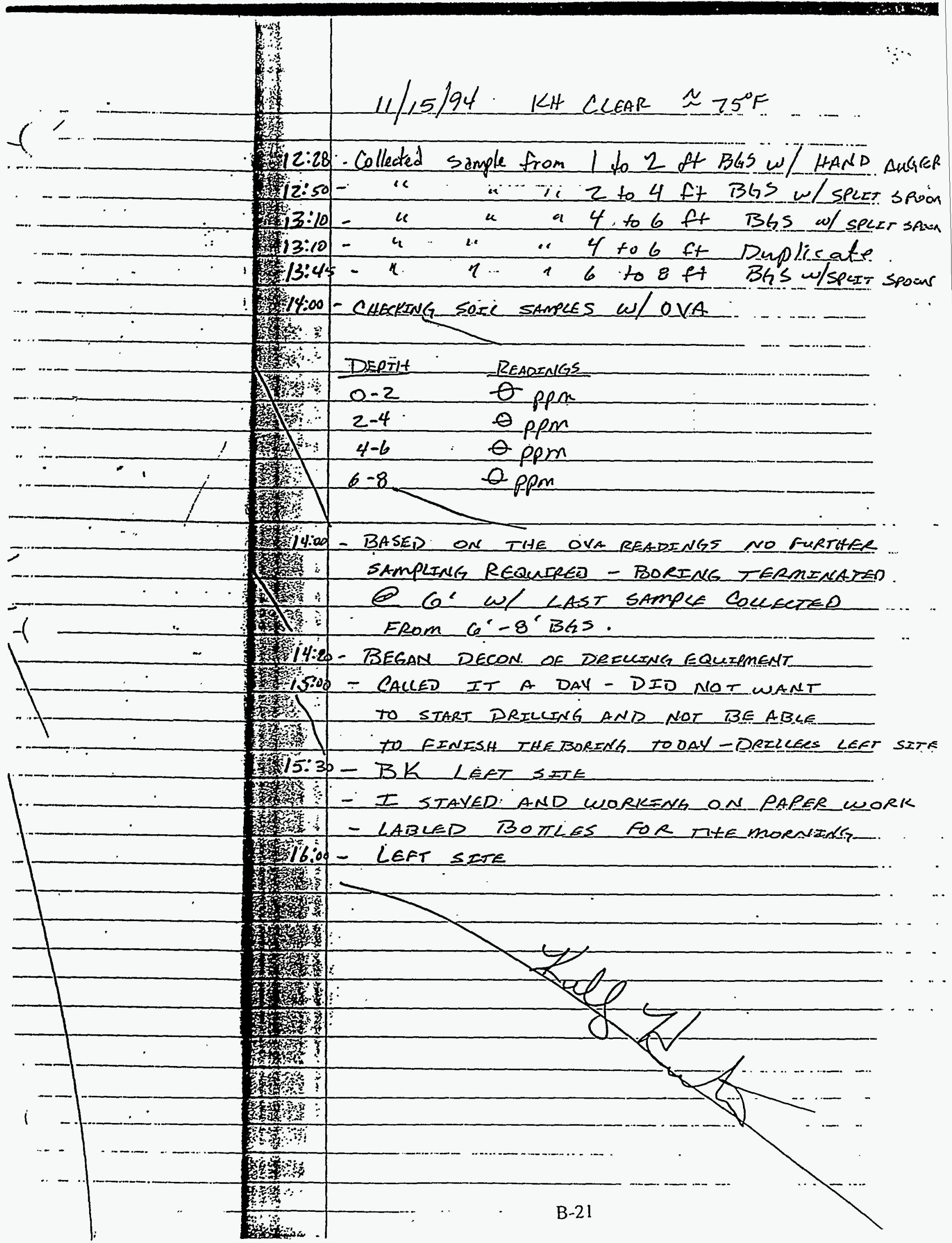




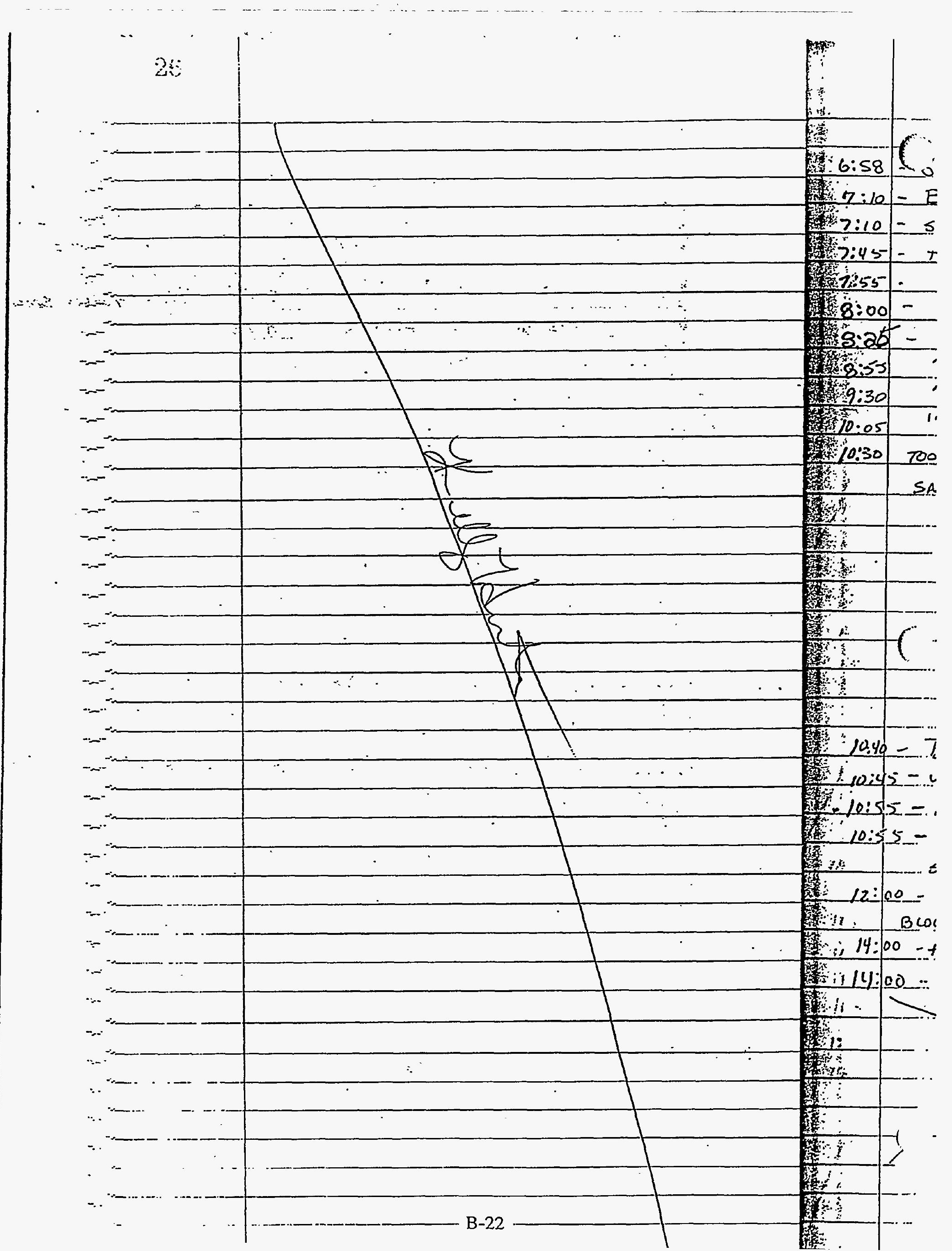




\section{$K H \quad$ CCO4DY $=68^{\circ} \mathrm{F} \quad \mid \mathrm{L} / \mathrm{L} / \mathrm{g} / \mathrm{94}$.}

- ON SITE - DRELLER ON SITE

- BK ON SITE - MOBE TO CS6G-014

- set un eor pays sampleng - calizrater ova.

- TOOK SOIS SAMPLE FROM O-I'BLS = HAND AUGER

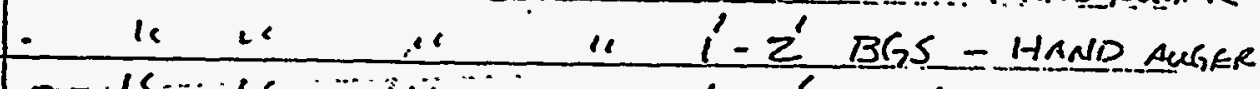

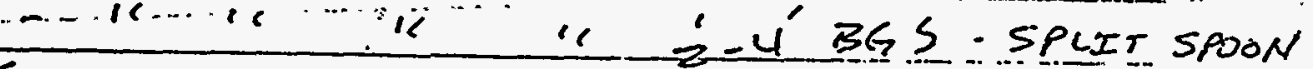

8.00

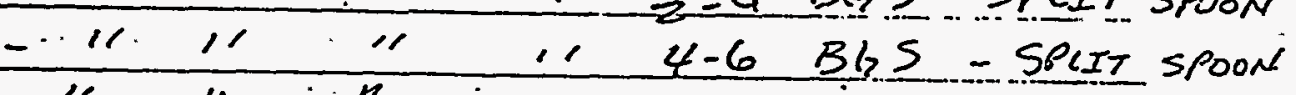

T.

$4: 9: 30$

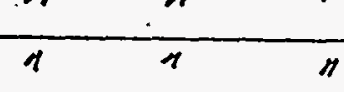

is ol 11

6-8. BhS - SPUT SPOon

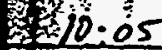

$410: 30$

TOOK OVA READINGS

SAMPLE INETERVAL

$0-1$

OVA READENG (PRM)

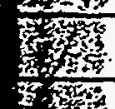

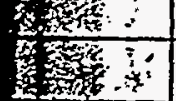

$1-2$

$2 \div 4$

$4-6$

156-8 8-10 B/25 - ... $13-15$ B43 $=$

-

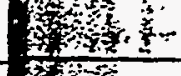

$8-10$

$13-15$

15

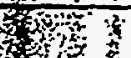

WHä - BORING TERMIENATEA @ / 5'BGS

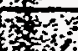

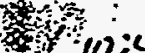

5 - WERC PERSONELL ON SETE
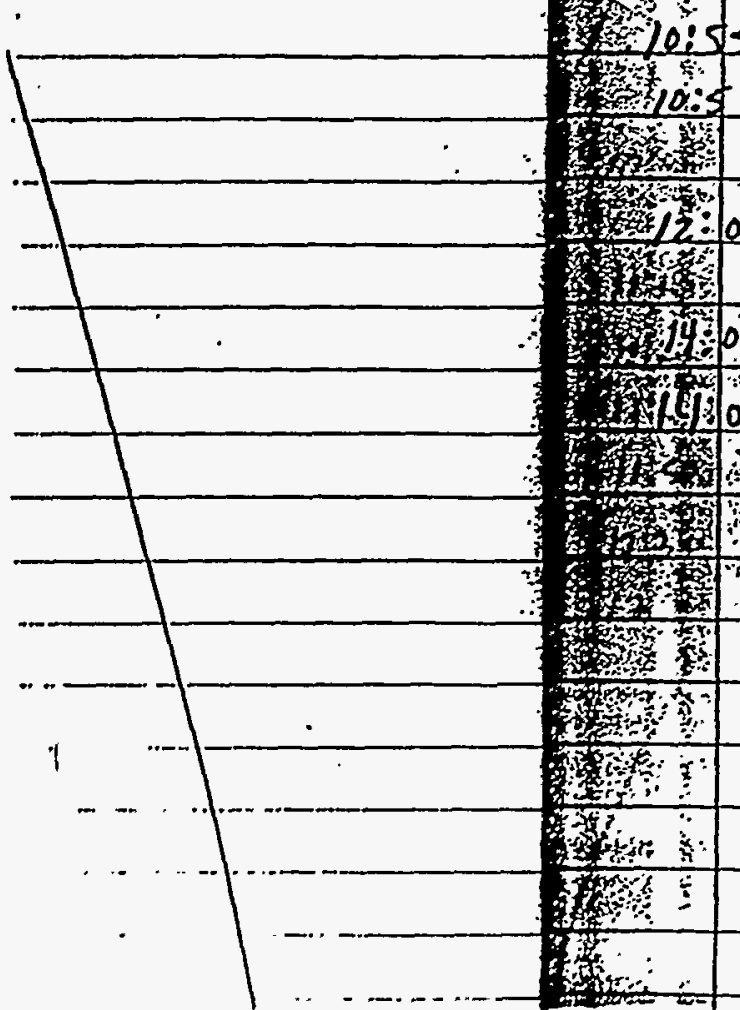

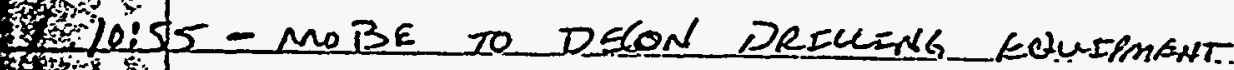

WD:S5 - MROBE TO CS612-15 B BEGAN GENEAL

SETUP

$00:=\angle I G H T$ RAIN WIL WAIT UNIIL IT

\section{裂等}

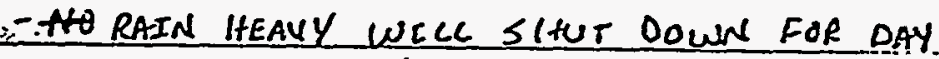

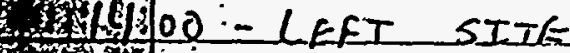
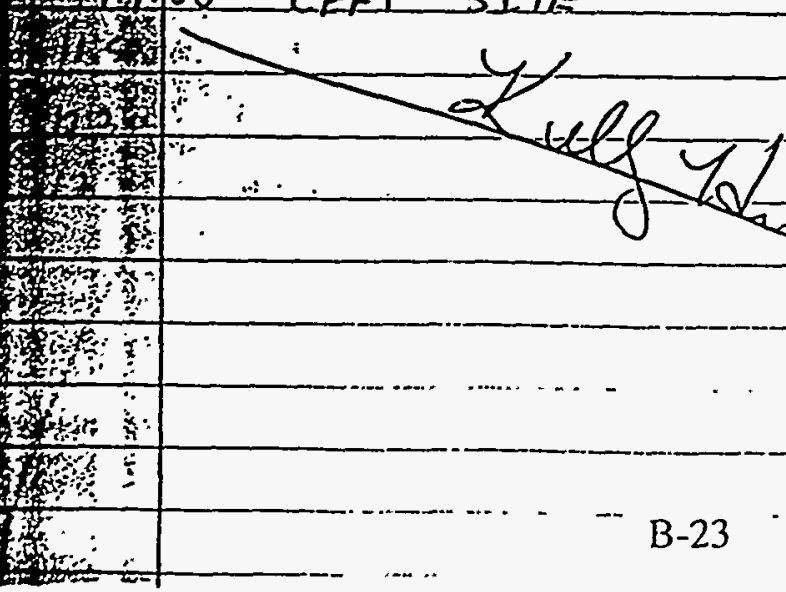

B-23 


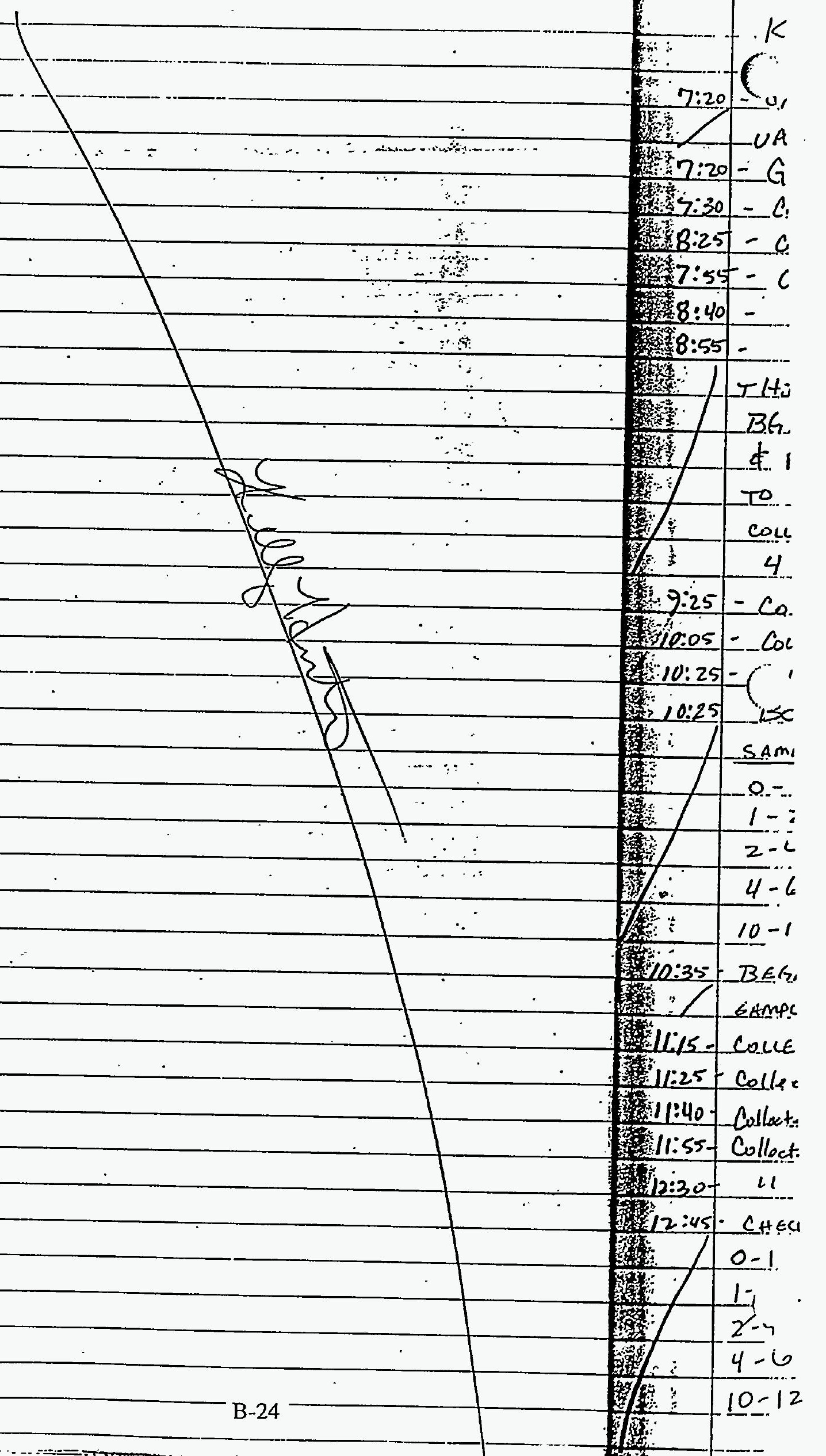




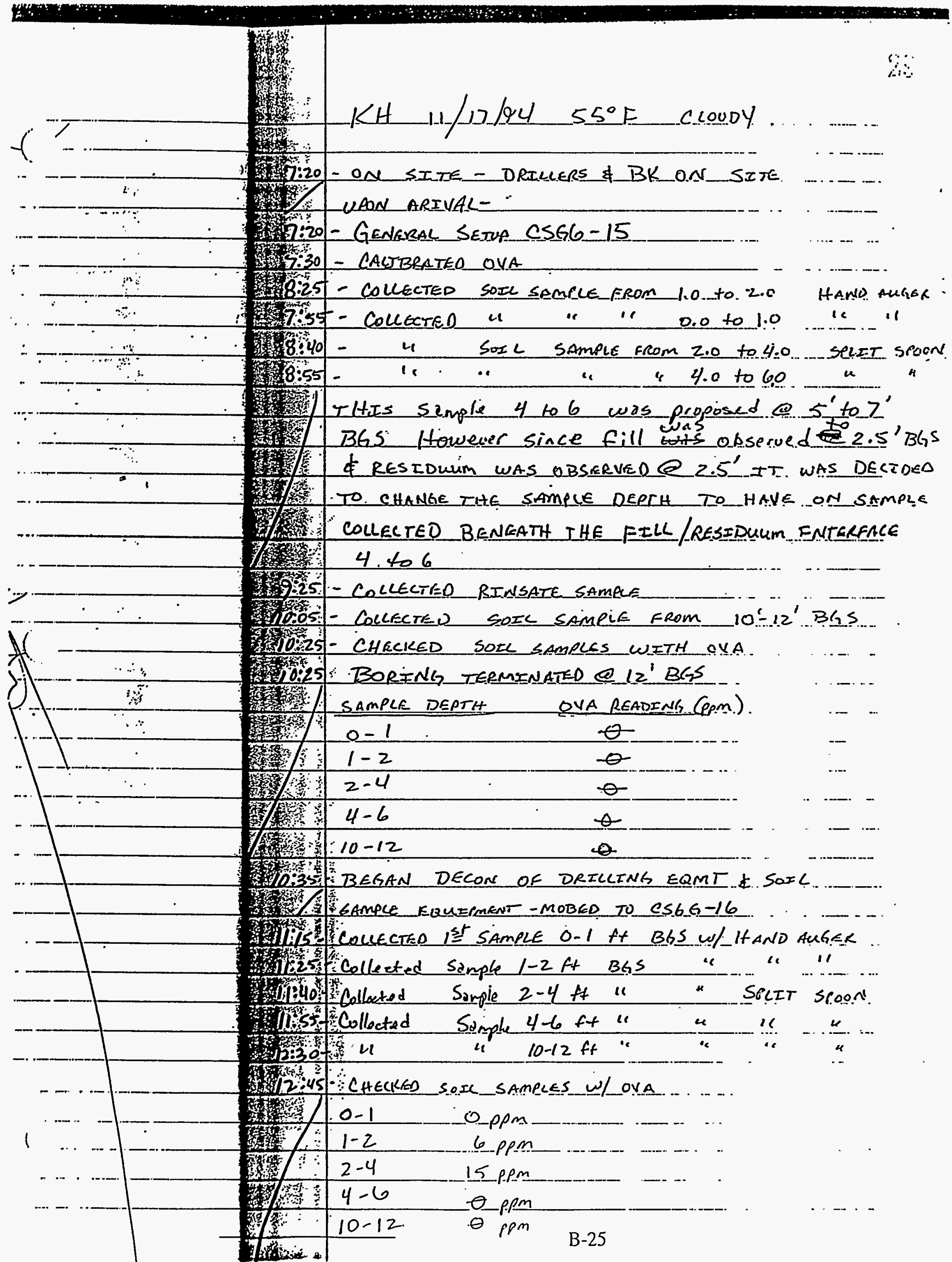




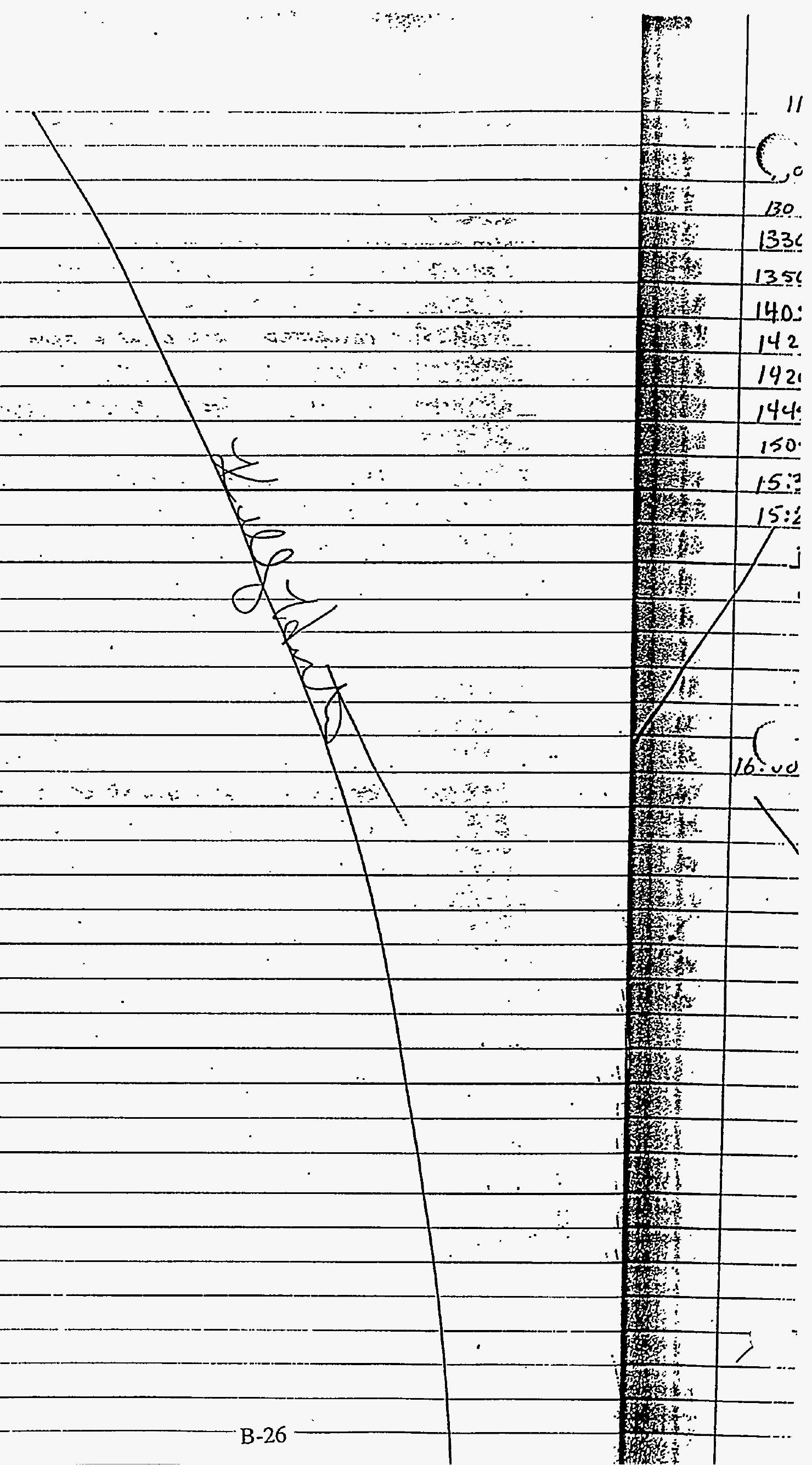


11. $117.94 \mathrm{KH} \approx 50^{\circ} \mathrm{F}$ Cloudy

BO0- BORENG TERMINATER @ $12^{\prime}$ BGS

DO BO - BEGAN DECON OF DRILCING EQMT

1330 - MOBBEO TO CS6G-17 LOCATION

1350 - Took. Ist SOXL SAMPLE EROM O-1'BhS

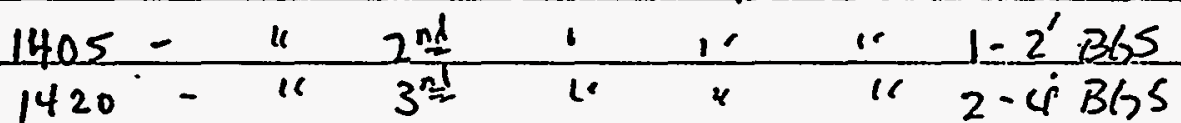

$1420-11320^{\circ}-"$ DUPLICATE OF $3=$ SAMPle

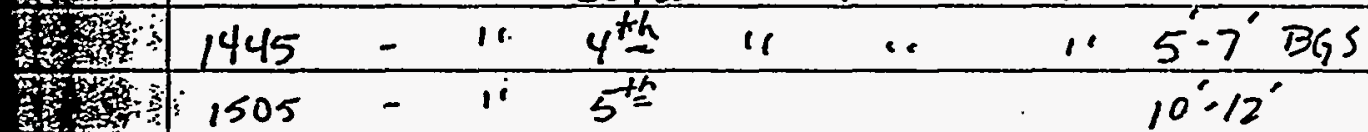

15:30-BEGAN GENERAL SITE CLEANUP-DECON

15:20. TOOK OUA READINGS

PEPTH OVA REAPENG (PPM)

$\begin{array}{ll}0-1 & \theta \\ 10.2 & 3 \\ 2-4 & 6 \\ 5-7 & \theta \\ 10-12 & \theta\end{array}$

$6: 00-\angle E F T$ SITE

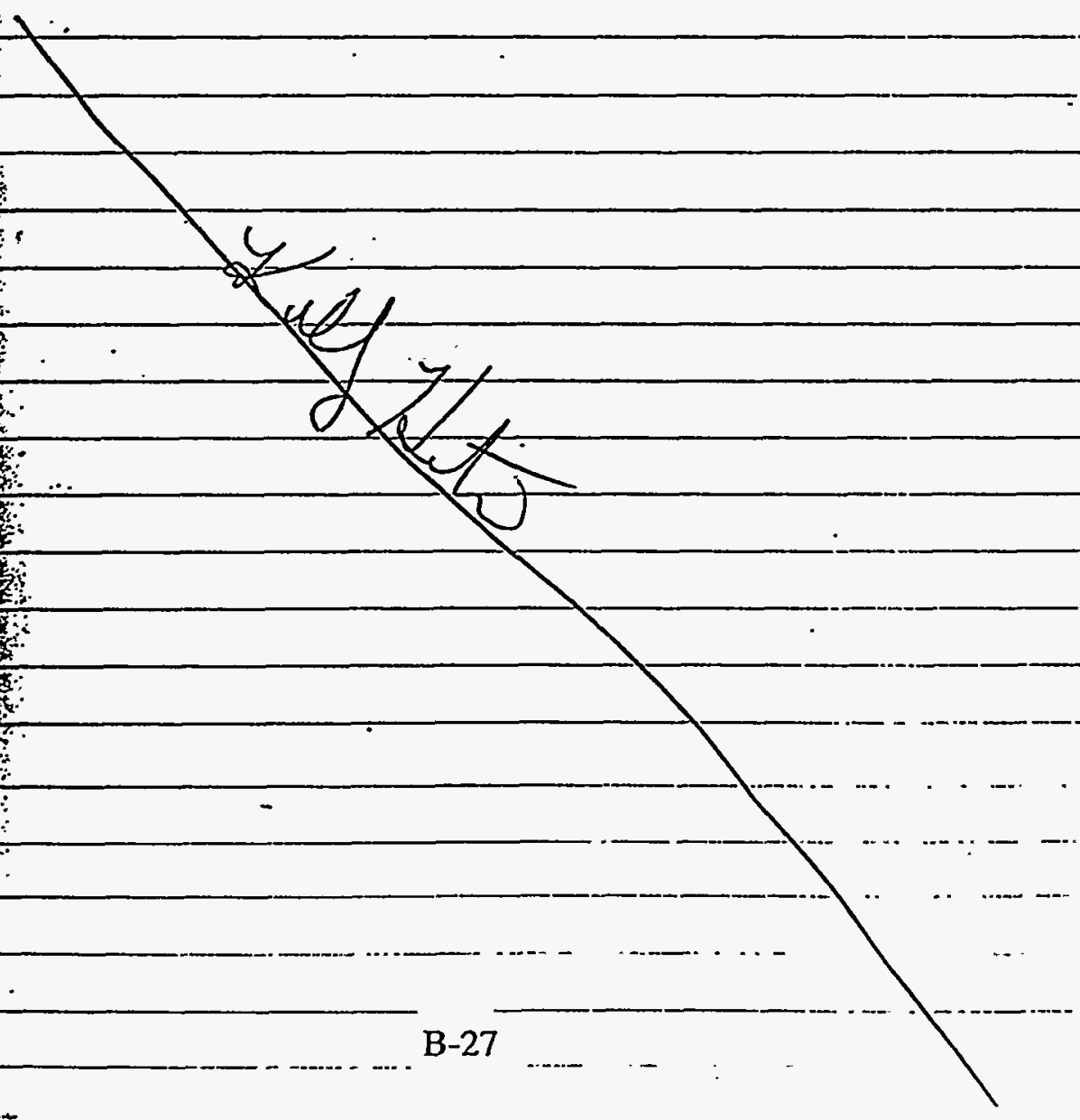




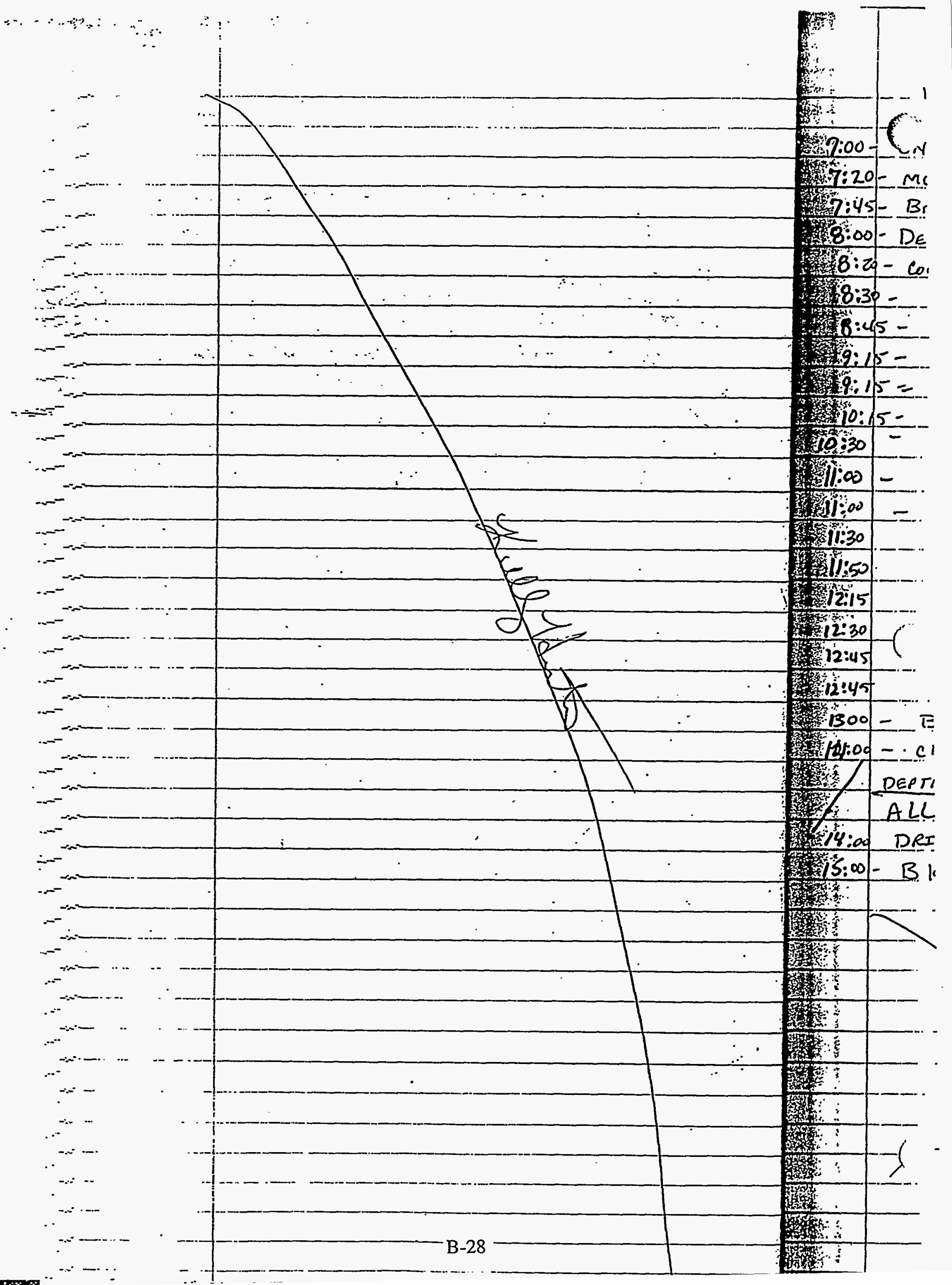




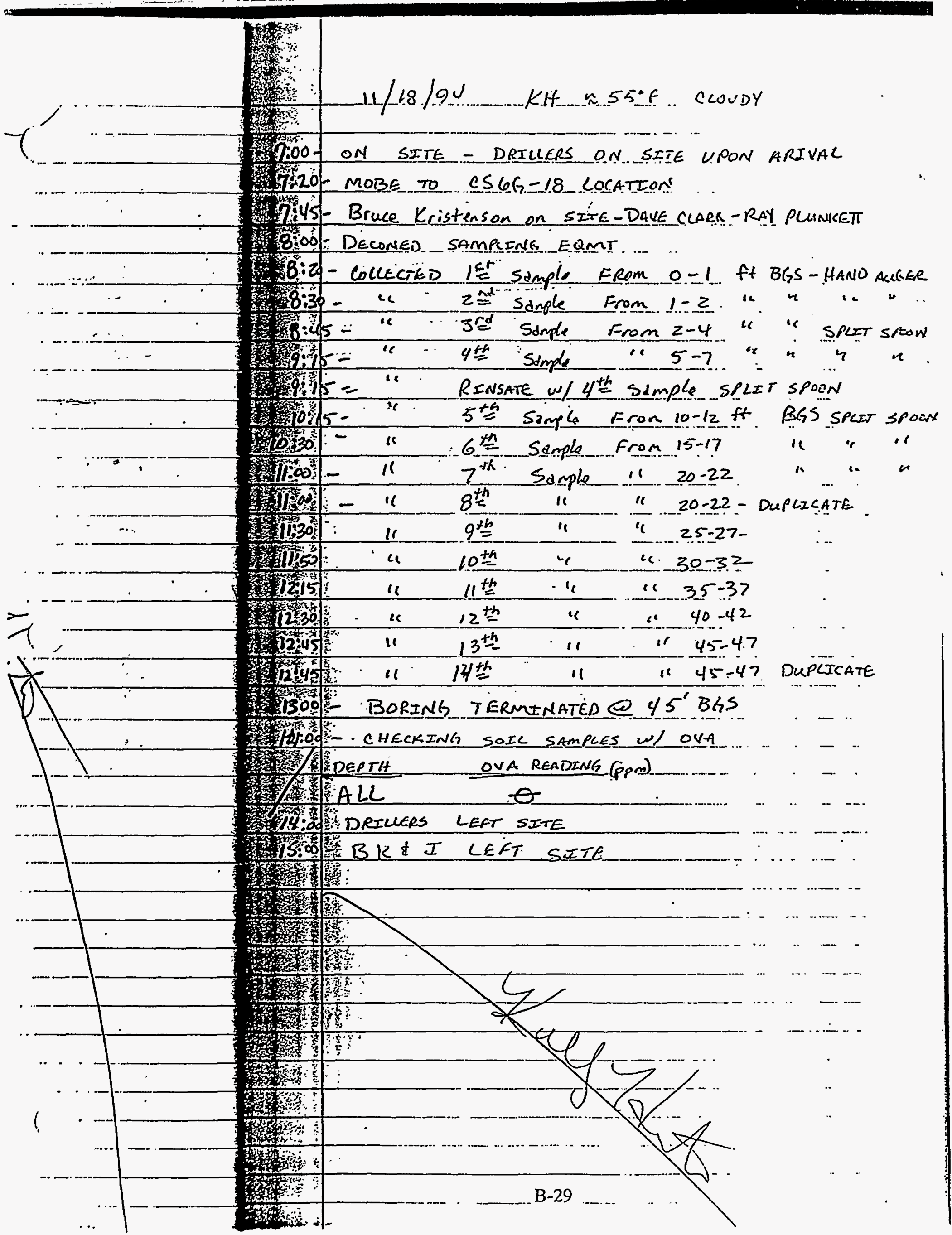




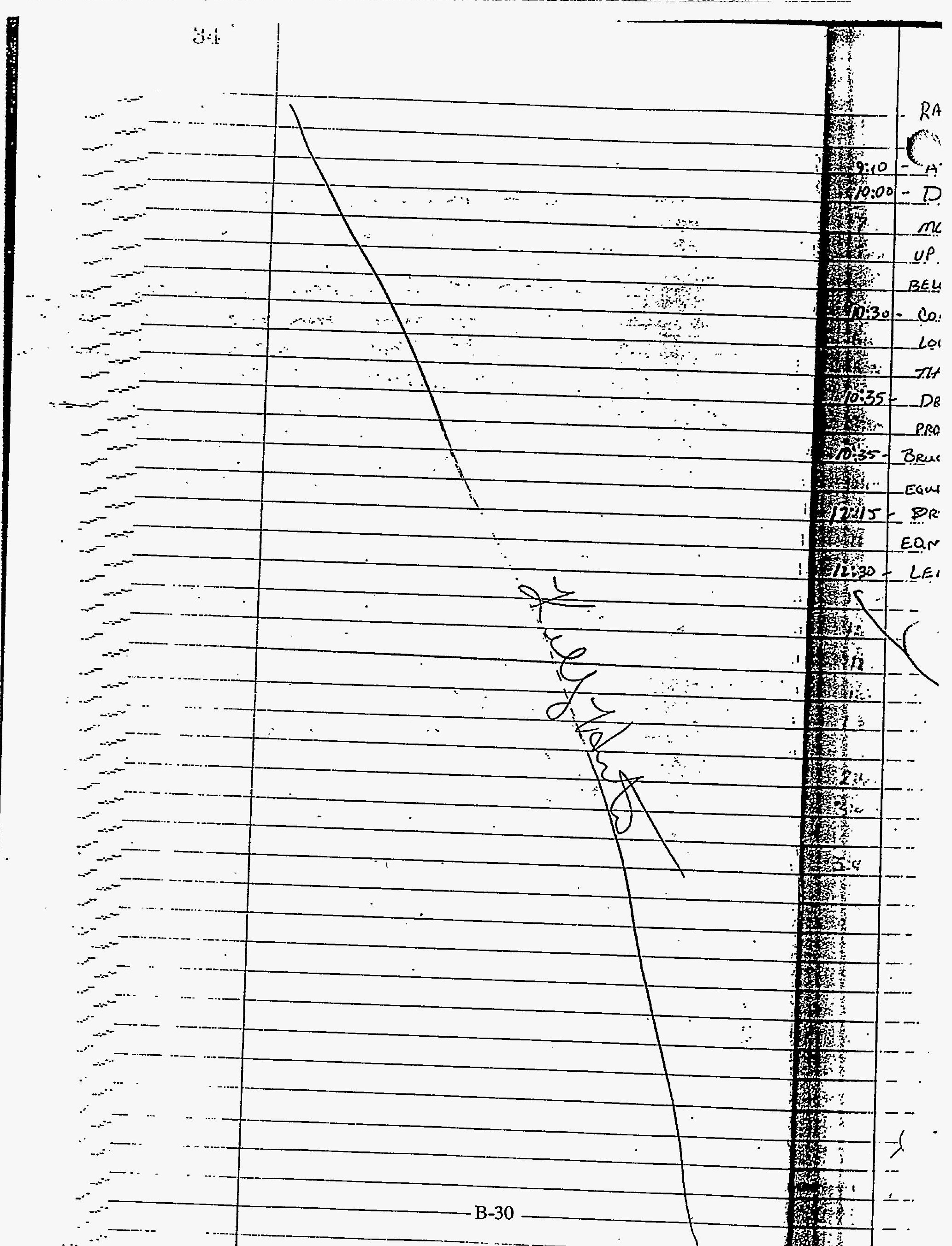




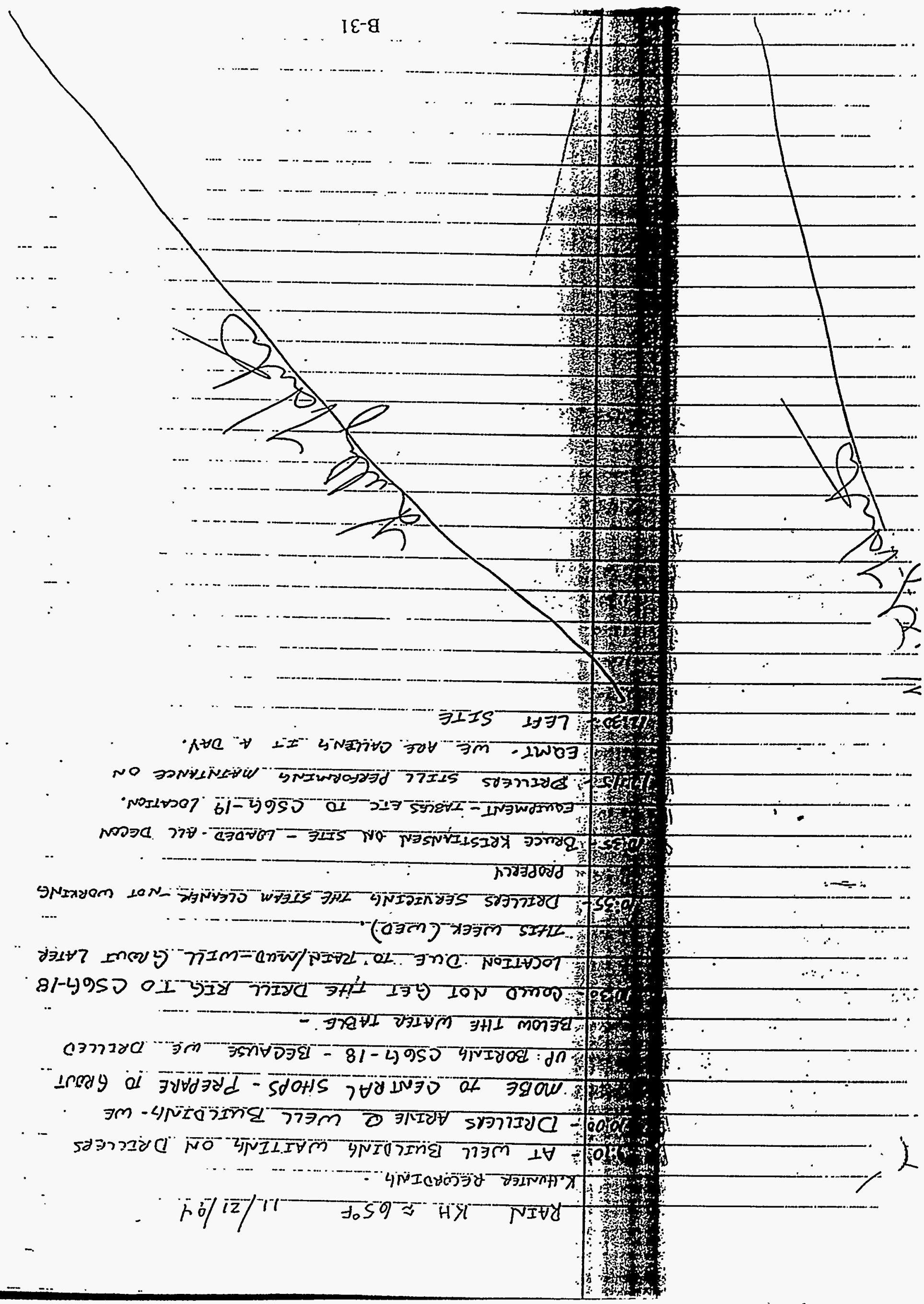


ii) $22 / 94 \quad K H \quad C L E A R \_5 S_{-}^{\circ} F \ldots$

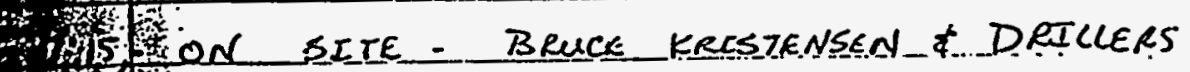

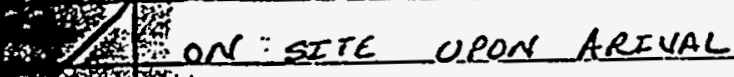

720. SET UP FOR SOIL SAMPLENG CS6G-19

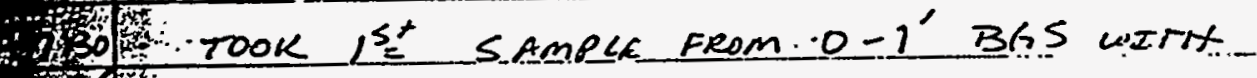

7. HAND AUGER -

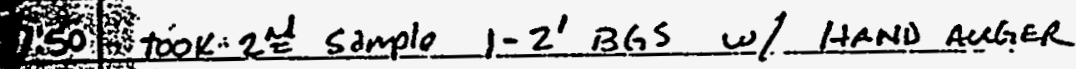

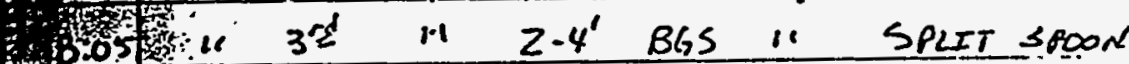

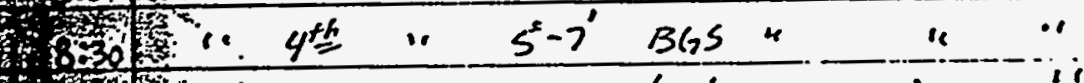

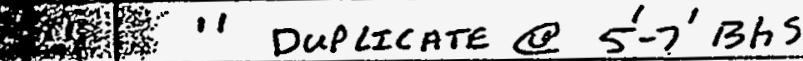

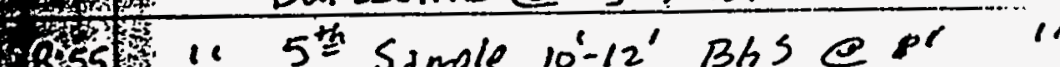

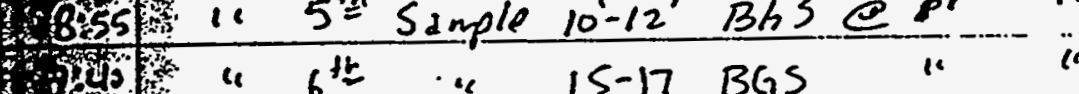

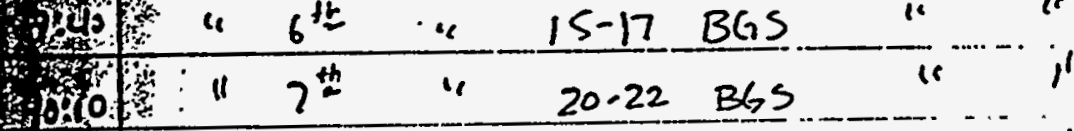

Tiacol " $8^{\text {rh }}$ " $25-27$ BOS

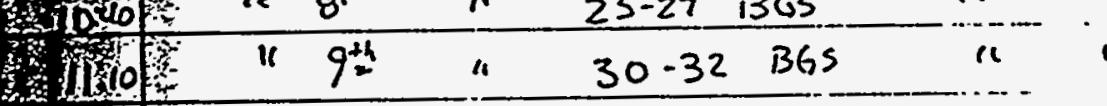

70 i $10^{\text {th }}$ " $35-37$ B 365

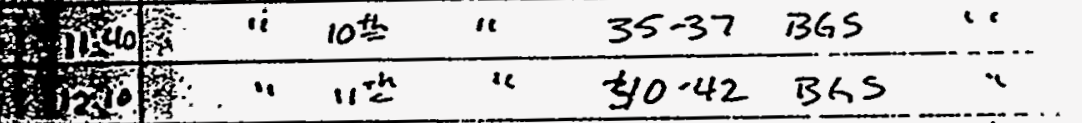

IIFY0 "O $12^{\text {th }}$ " $45-47$ B65 " " " DUPLICATE

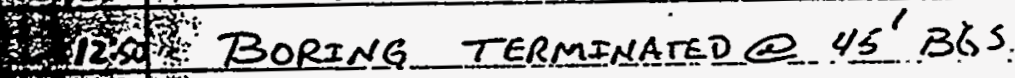

W.30. 1\% DRILLER LEET SETE TO GET SUPPETES FOR GROUT

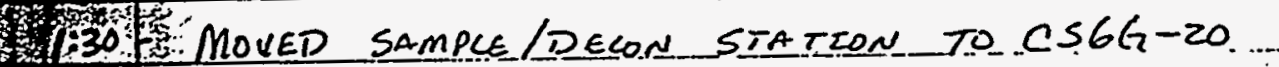

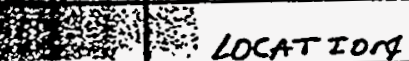

W: 20 : DRILLERS BACK ON SITE

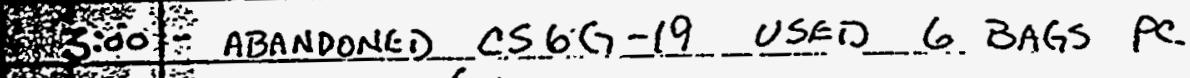

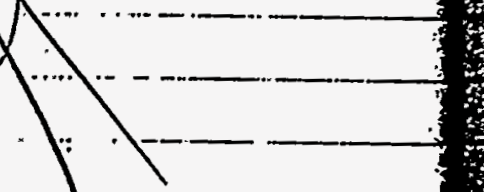




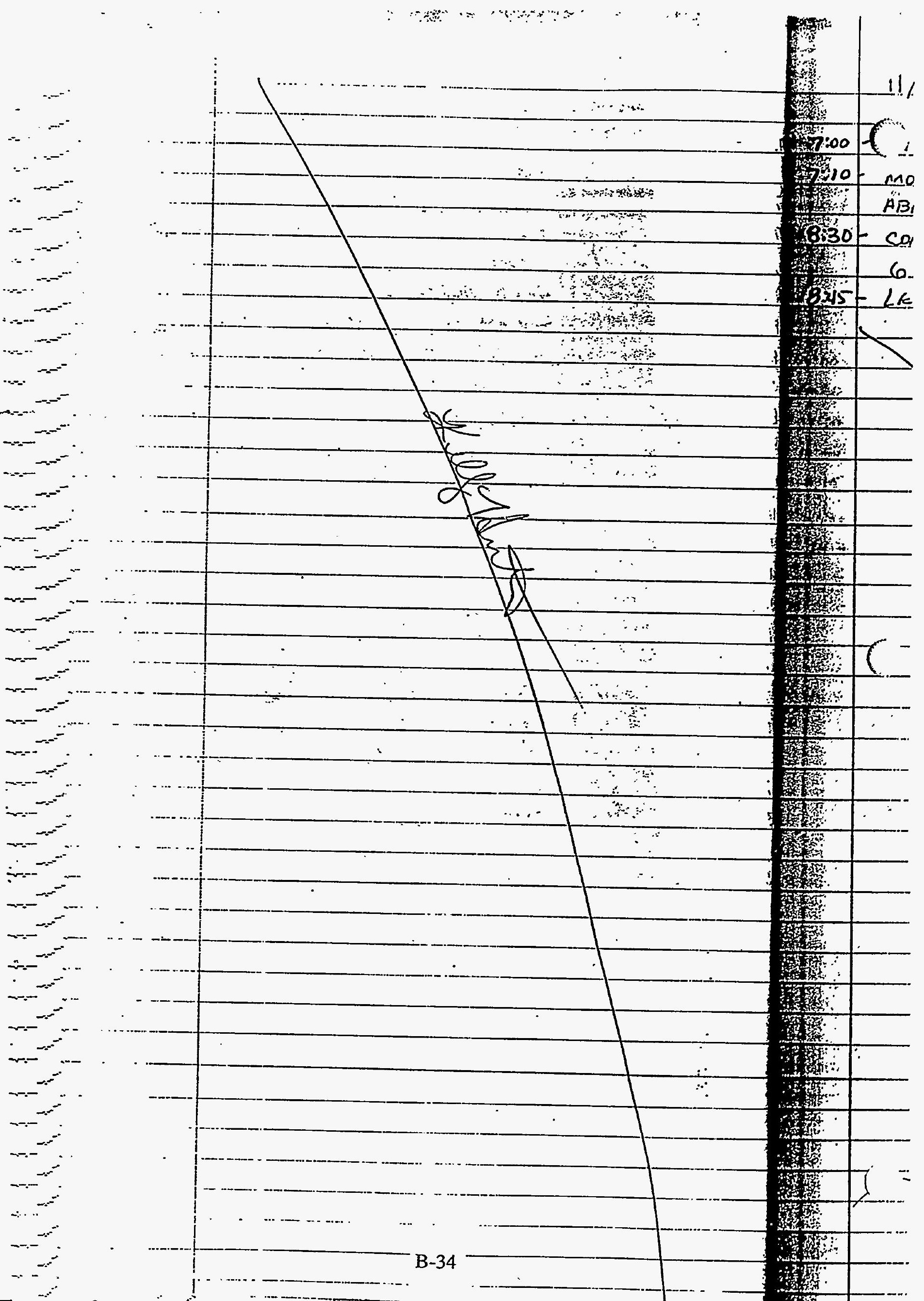




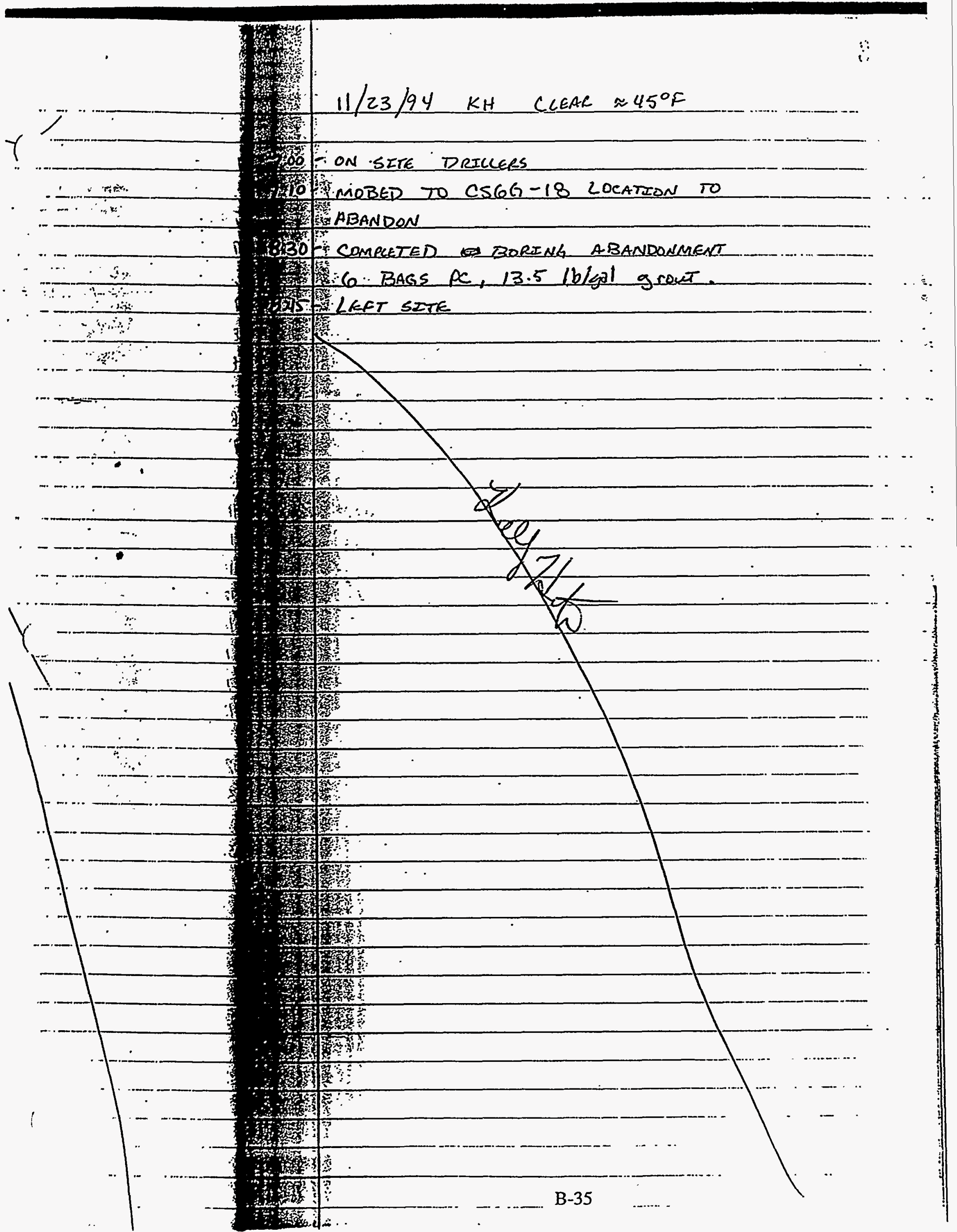




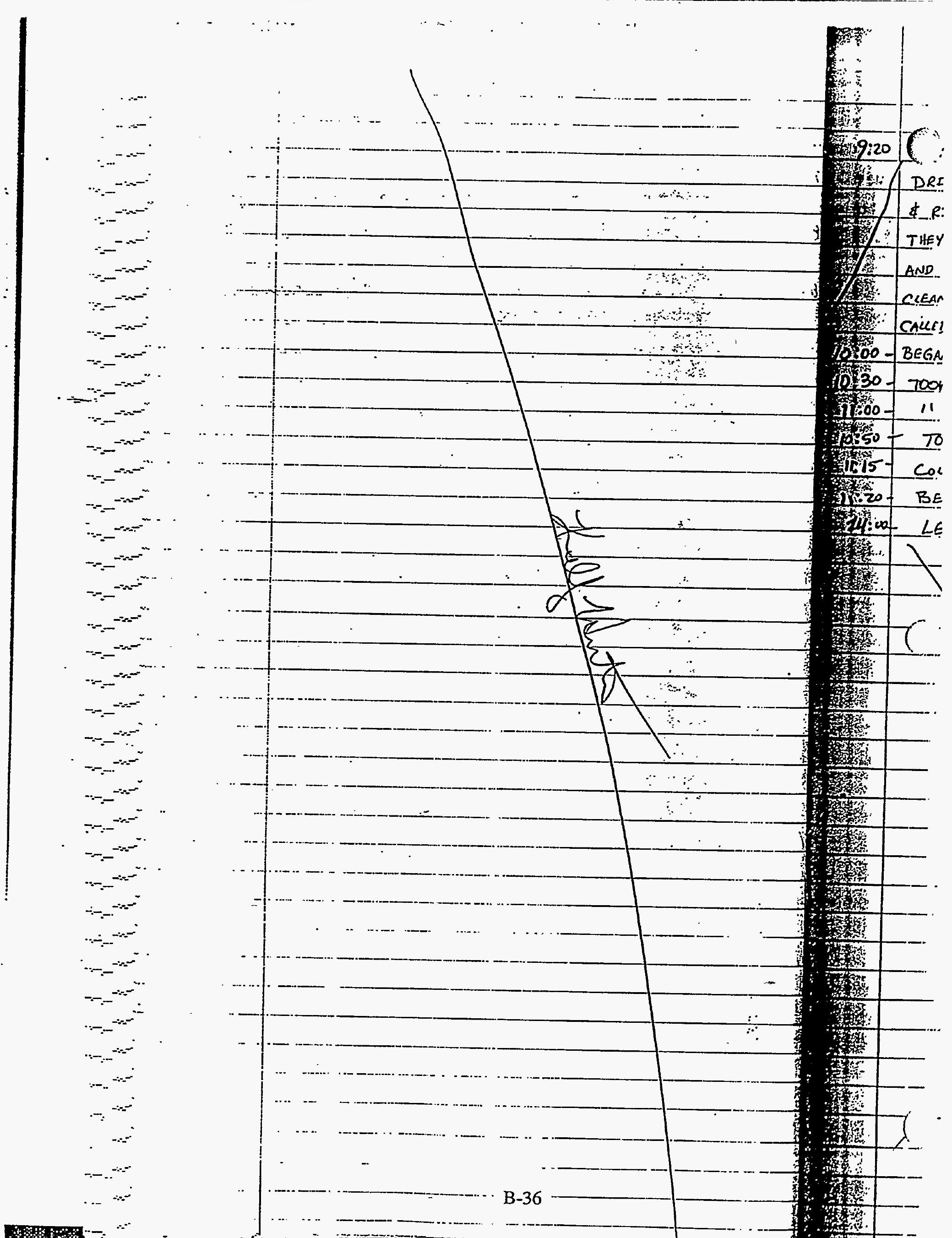




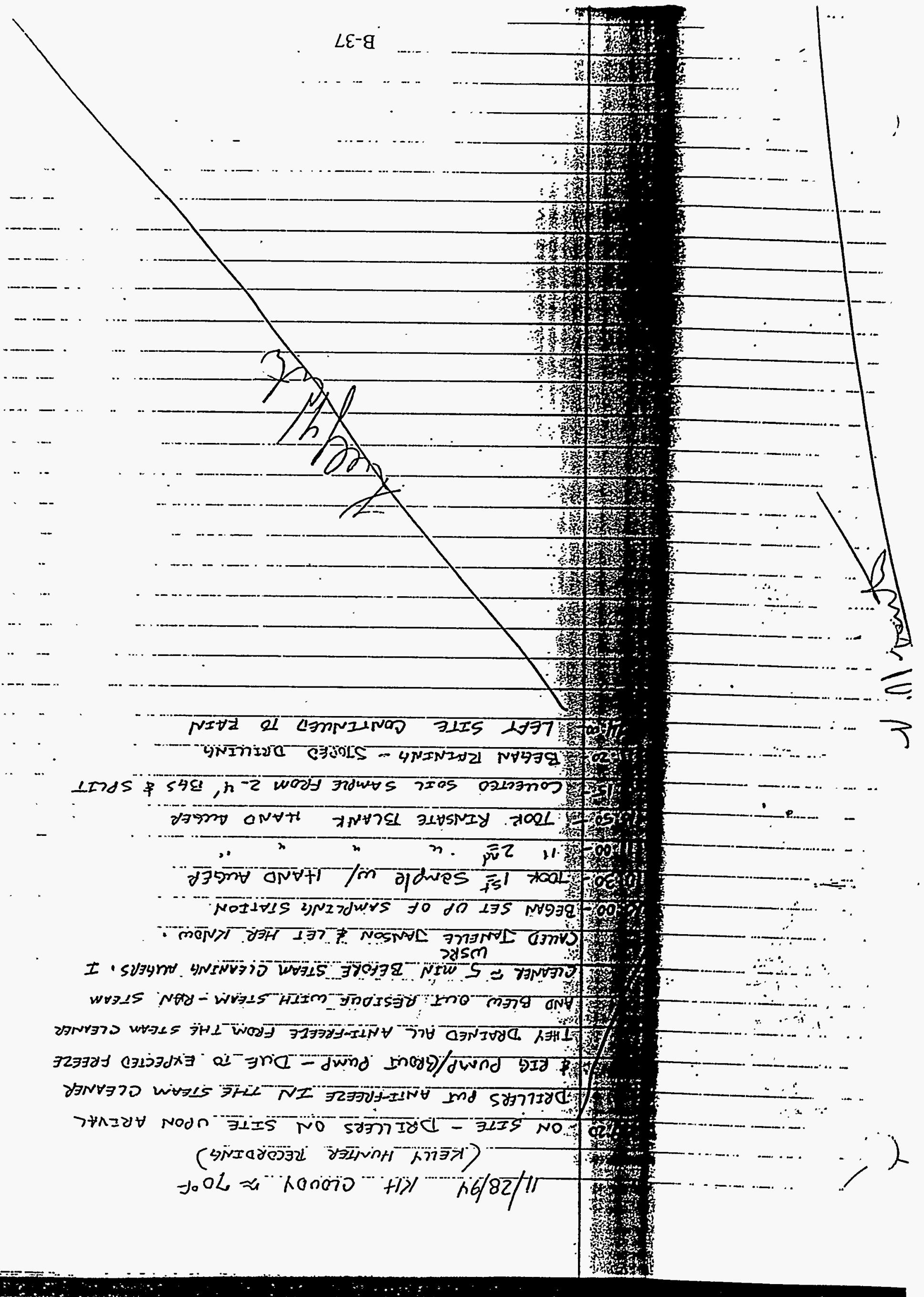




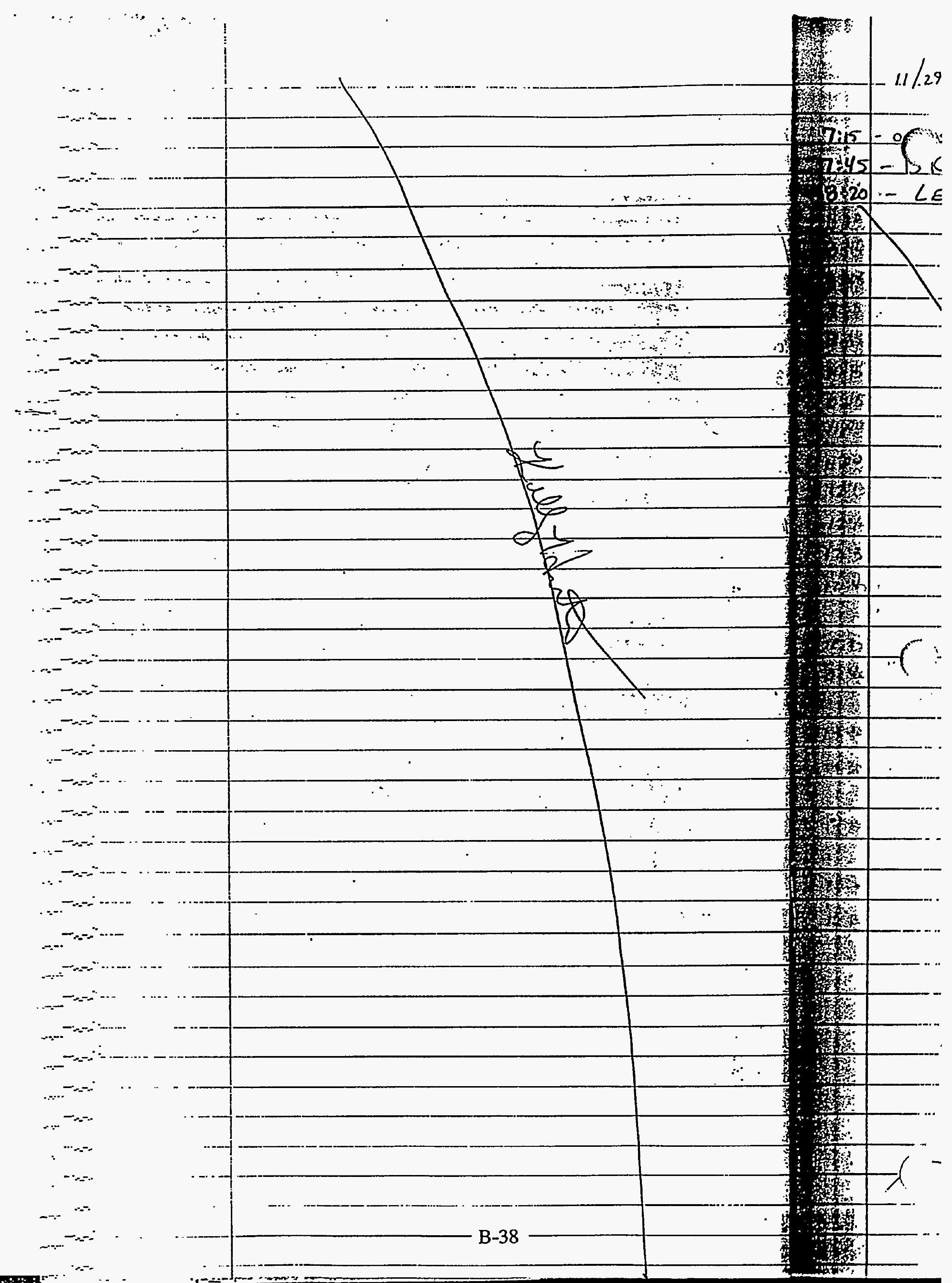




$$
1
$$




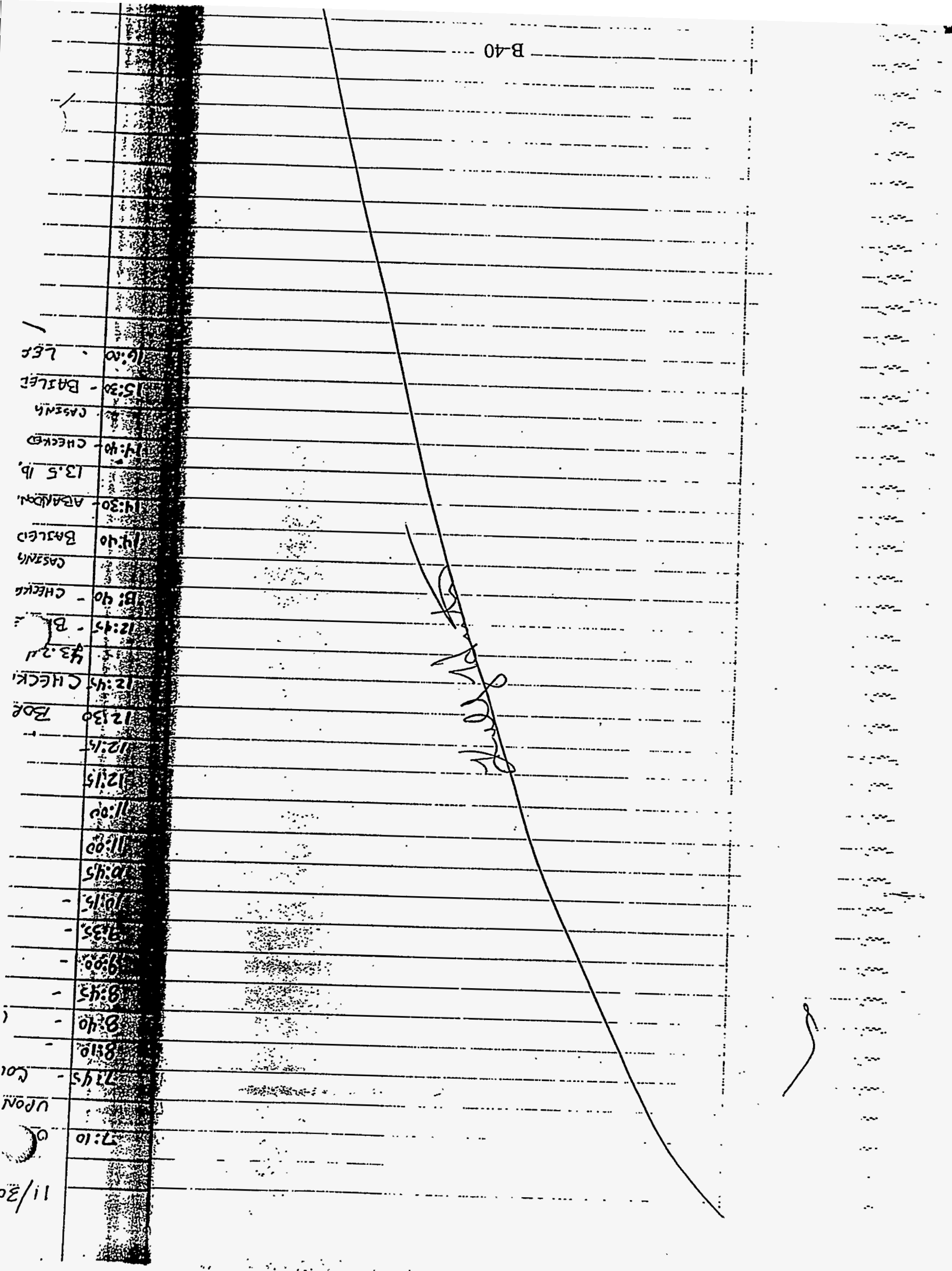




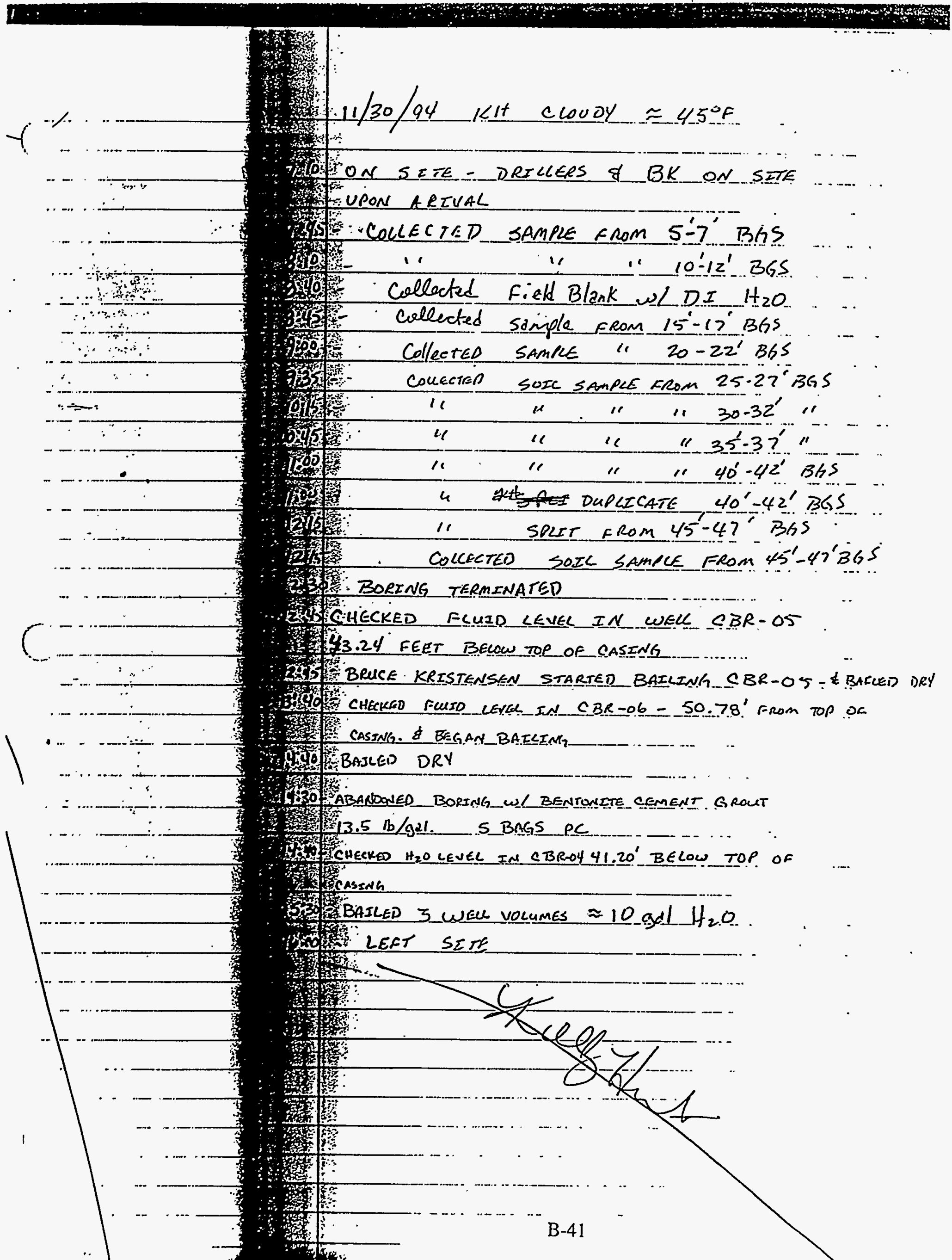




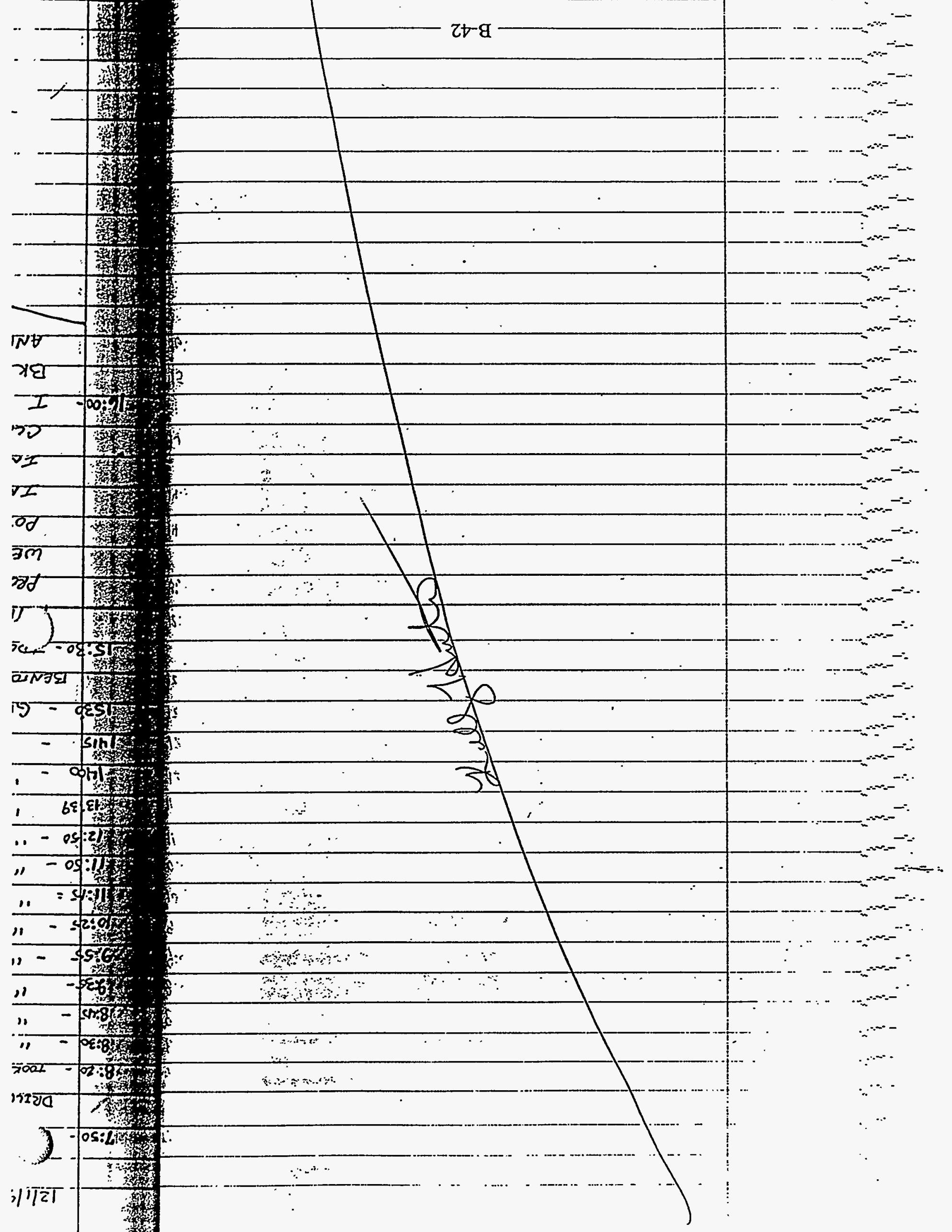




\section{$12 / 1 / 94 \quad \mathrm{KH} \quad$ CLEAR $\approx 48^{\circ} \mathrm{F}$}

ON SITE BK \& DRIULRS ON SITE UPAN ARIVAL

DrJuker SETEMG UP ON CSGG- 21 BORING

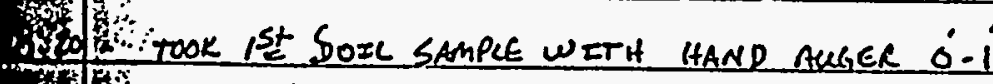

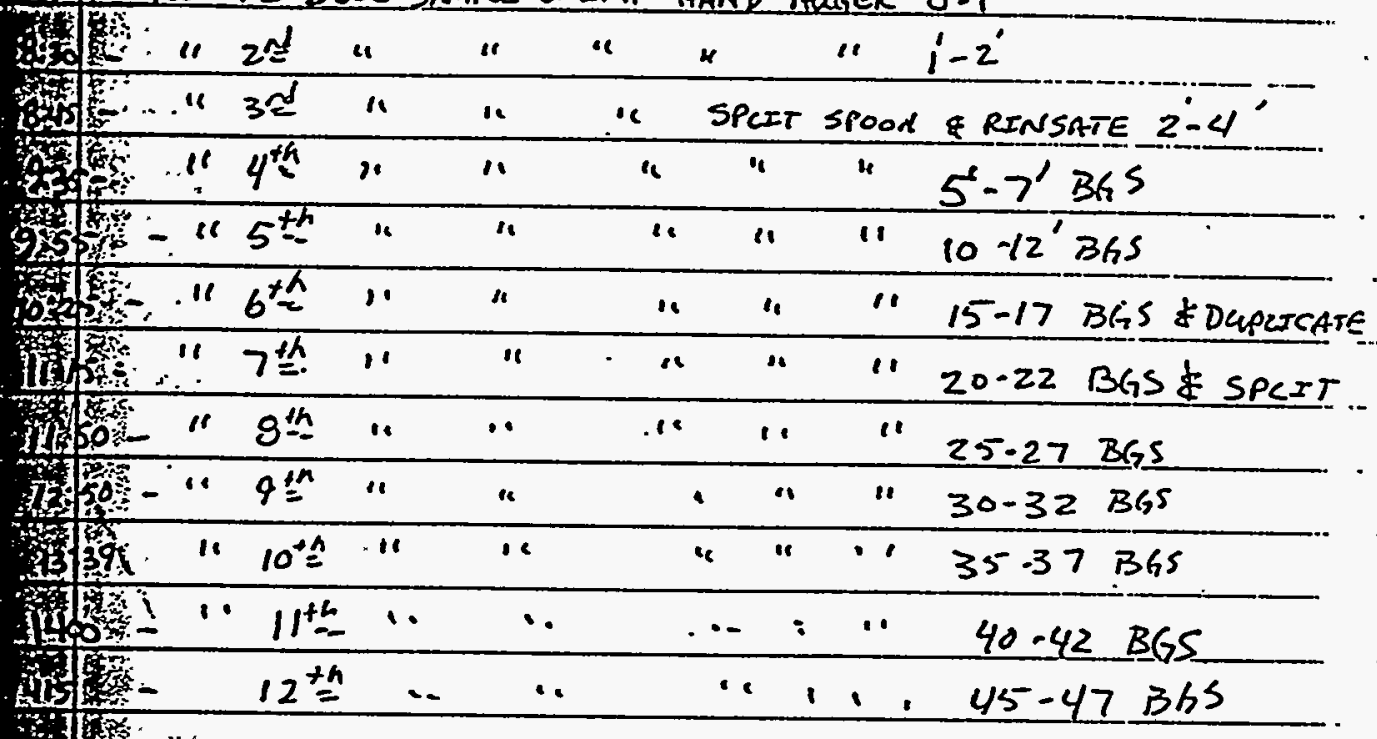

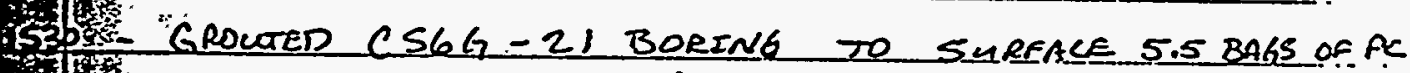

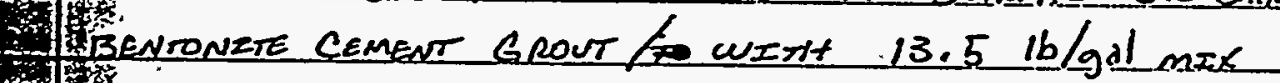

IS SOH TOK RTNSATE SAMPLE FOR WEL CBR-TZ

- WE TOETER WE TIE SAMPLE WE NOTISED THE

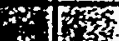

- IE PROTECTIVE COVER WAS FRESHLY PAFNTED $\approx$ H HOUR.

WE WE DECEOED NOT TO SEMPLE THE WELL DUE TO

3i POTENTIALY CONTAMFNATENG THE SAMPLE \& THE

WE WIS TNTEGRTT OF THE WEL - WEU TRY TO SAMRLE

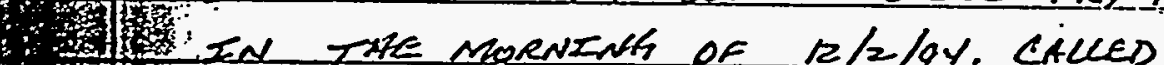

SIS CLARK AND NOTEFLED HEM OF THE STTUATEN

30. I SPOKE W/ DAVECLANK (WSRL) AND TOLD HIM

* HW BK \& I WOULD BAIL THE WELSS ON SUNOAY

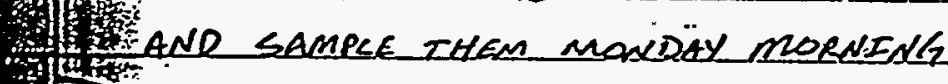

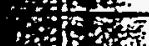

,

.

Stis

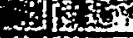

密

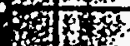

$3 x$

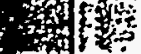

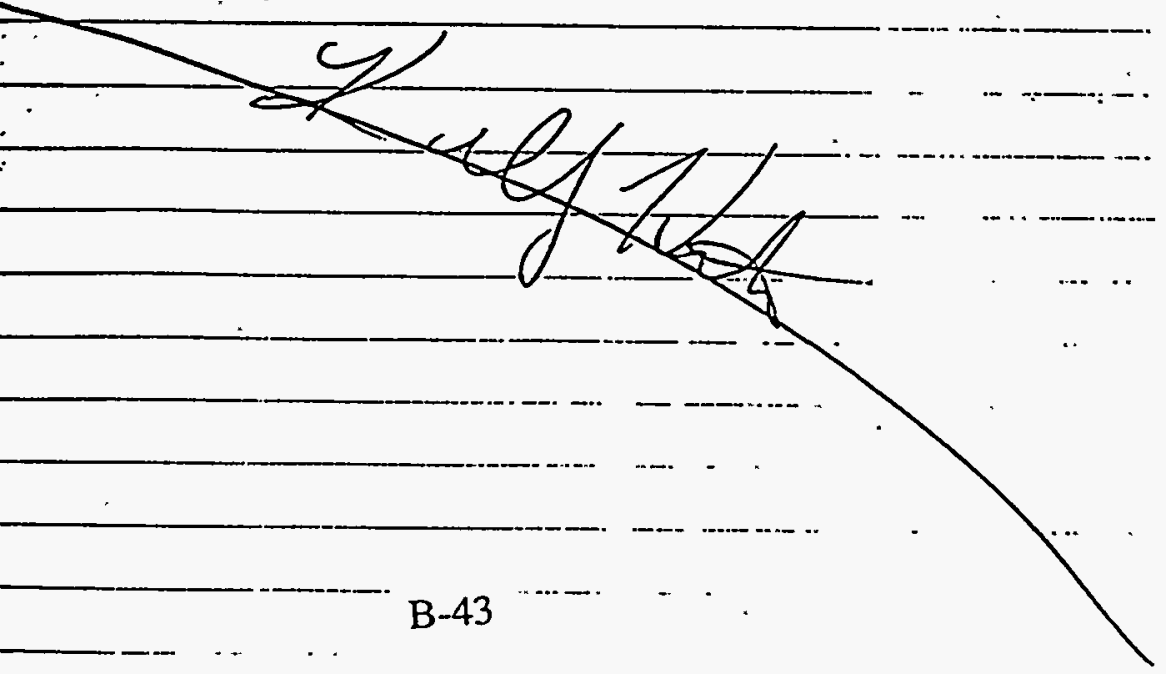




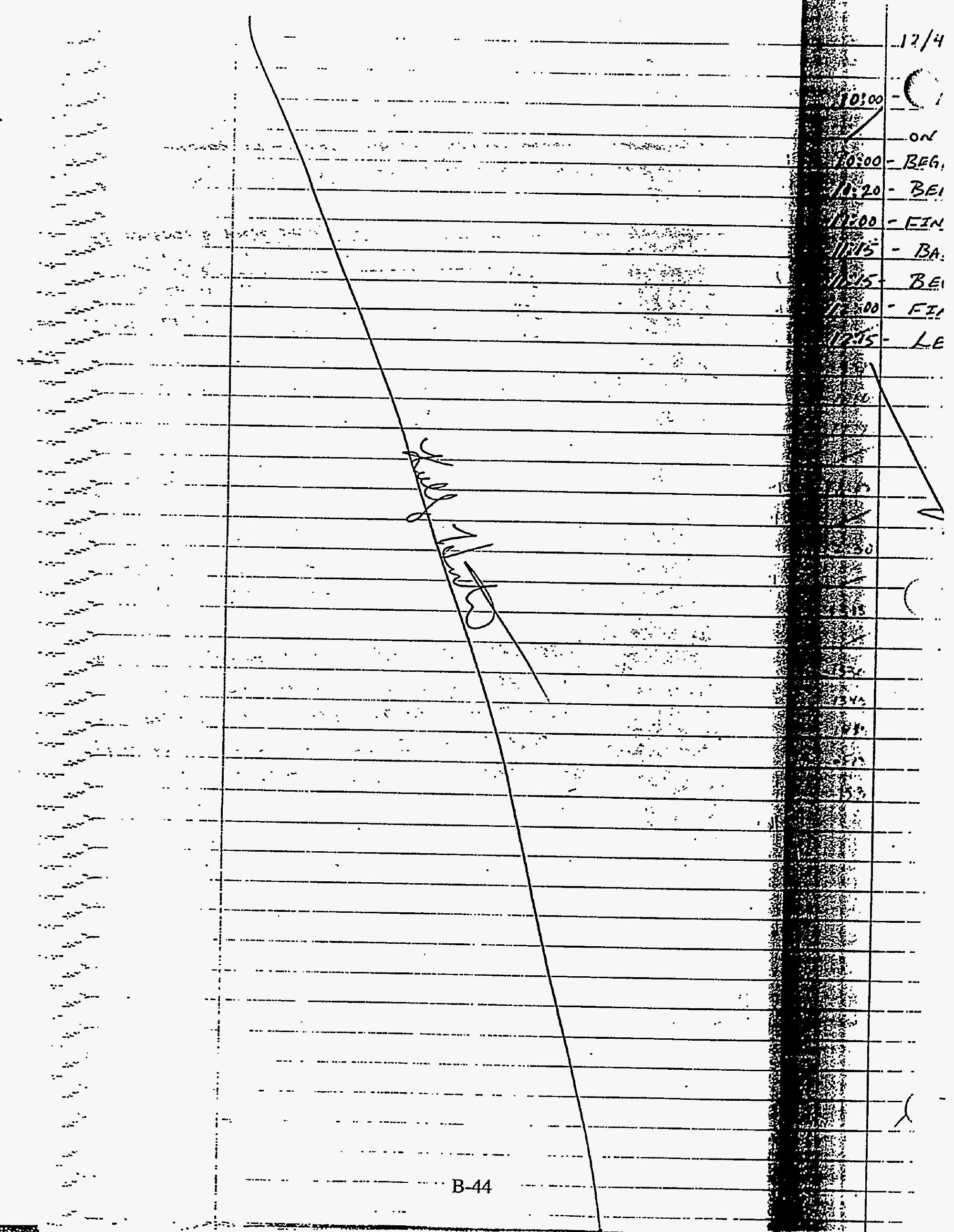


$12 / 41 / 94 . K H$ CLOUDY $\approx .65^{\circ} \mathrm{F}$

$\because$ HOO - ON SITE TO PURGE WELLS FOR SAMPLENG

3.6. $12 / 5 / 9.4$.

ste

HO BEGAN BAILENG B..CBR=OS - B.KUCE KRISTIANSON HD BE BETAN BAILING..CBR-OU.-. KELCY . HUNTER

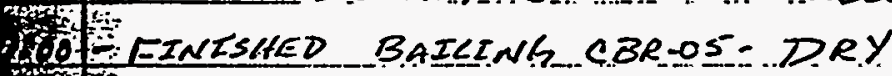

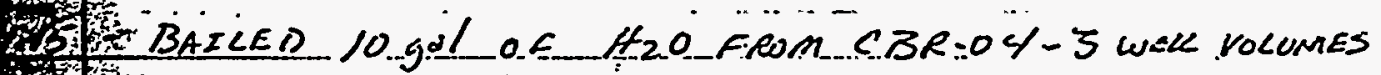
SES BEGAN BATLENG CBR-06-

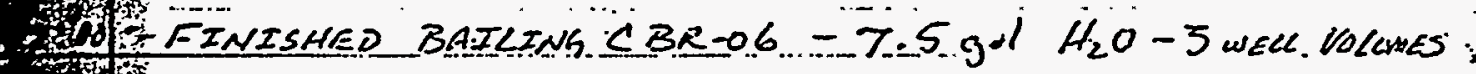

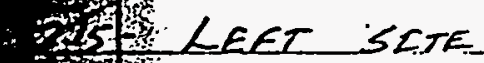

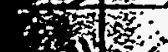

(n)

Ant

$\theta$ 委

校

攻

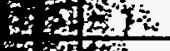

\%

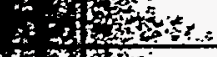

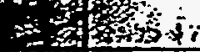

\% 3

ard

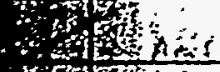

-

or

$\therefore$ at

7)

, s

程

\%

$\therefore 5$ \%

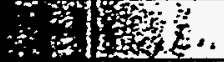

nd to

4

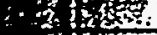

$1 \%$

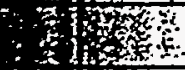

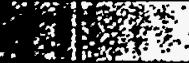

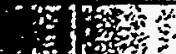

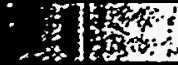

$\because$

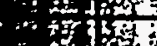

新

3. 


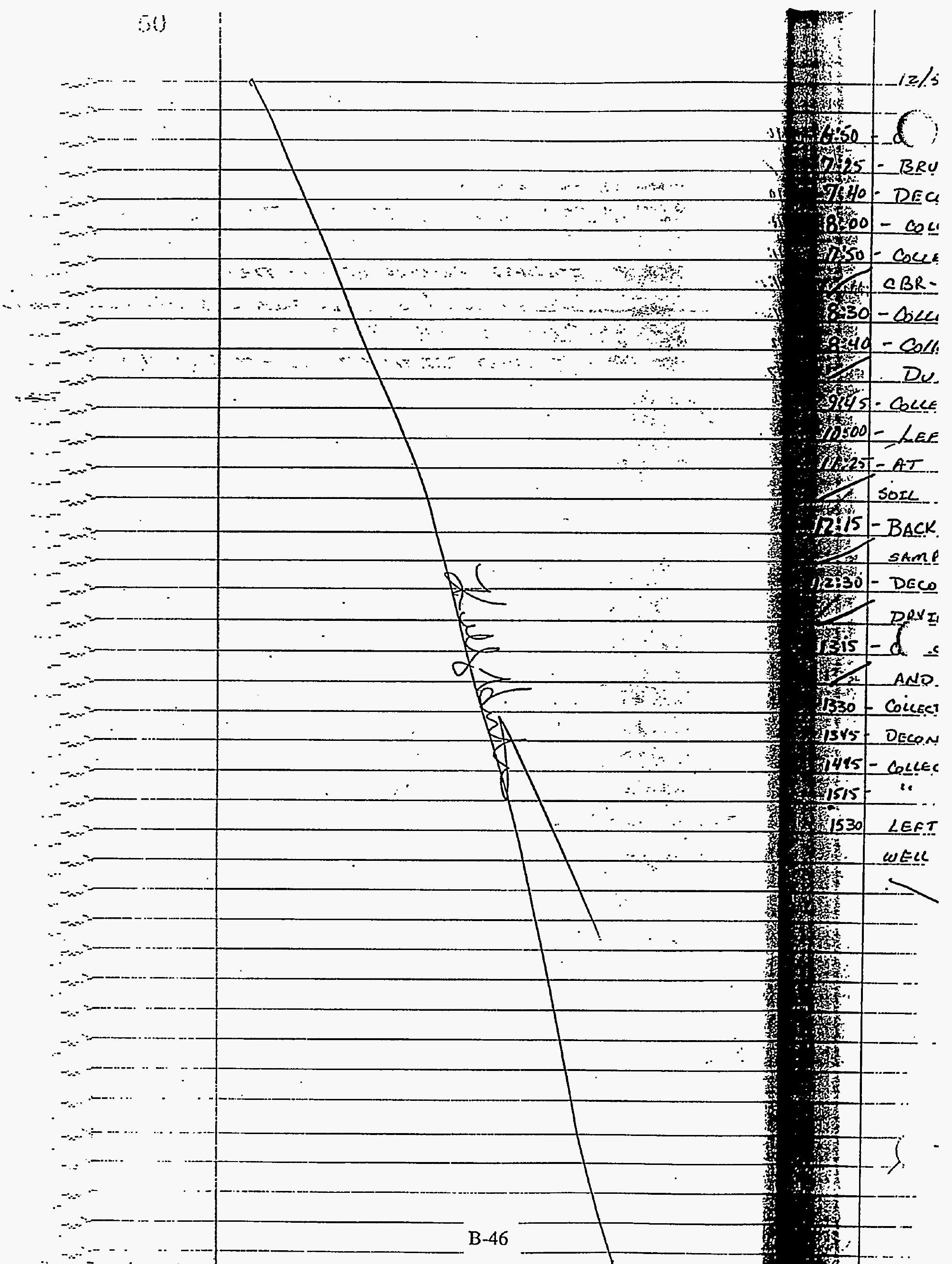


,

* $12 / 5,94$ KA $P C \approx 65^{\circ} \mathrm{F}$

tis

KELLY HUNTER RECORDING

H. WON SITE TO SAMPLE WEUS

WBRUCE KRISTIANSON ON SITE

$\therefore$.

19. IDECONED SAMPLENG EQULPMENT

$\because g$ U COLLECTED EIELO BLANK

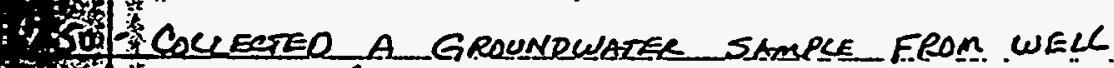

$\angle B R-05\left(C B R-T_{2}\right)$

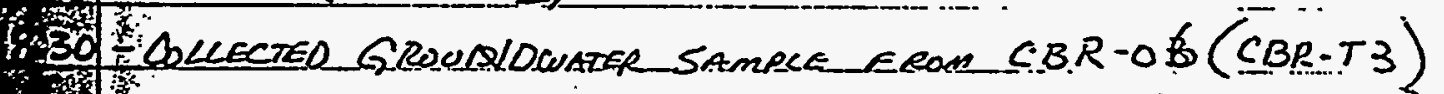

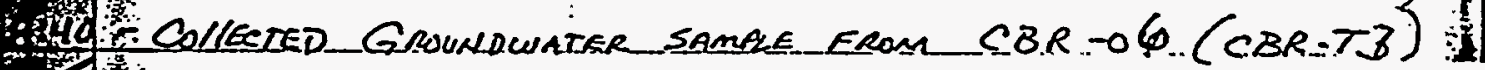

W. DUPLECATE \& SPLIT

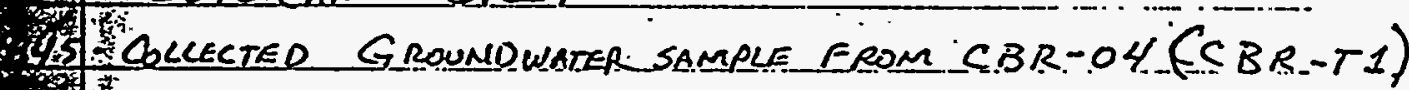

HOO

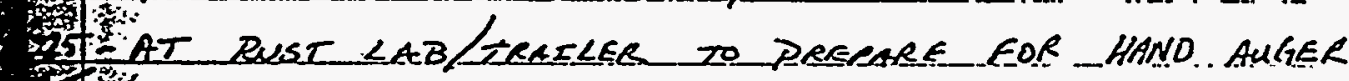

SOLL SAMPLES

.

i7. 15 SBCK ON SITE TO COLCECT HAND AUKER SOIL

ISAMPLES

30 DECONED SAMPLING EQUIPMENT - WAITINS ON

$\because$ Y PRYING

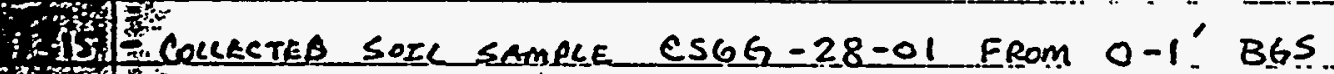

1.

130. Coilected SOIL SAMELE CS6G-27-01 FROM 0-1'B6S

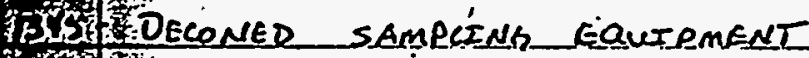

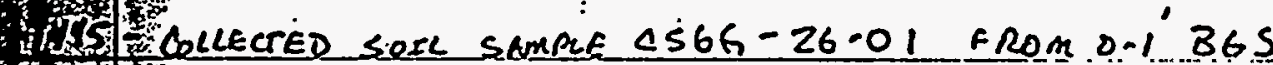

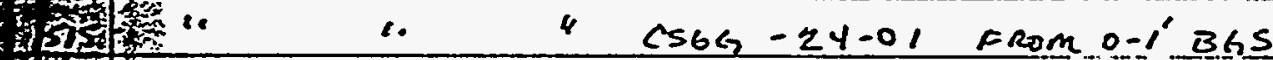

S3O JELET SITE FOR TRAILER A DELIVERY JAMPLS TO FEEL BurLDING

rinetse

istions

H.

(1)

$\because ;$

$\rightarrow$ int

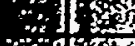

.

$\%$ 椊

济

4 

$\because 12 / 6 / 94 \quad K H \quad$ ceouoy $\approx 65^{\circ} \mathrm{F}$

SiR: ON SITE

- THOOH: DECONED SAMPLING EQUIPMENT

\section{- in : Collecrea sorc sampece}

910 COLLETED SORC SAMPCE CS6G-25-01 O-1'BHS

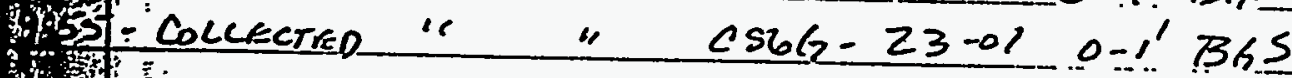

H.OHO-DECONED SAMLLE EQUTPMENT

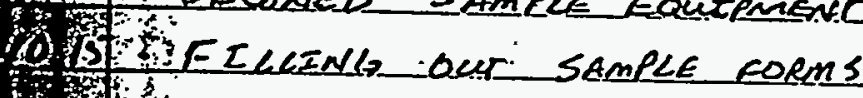

1 6 Ho - IDEAN THOMAS ON SITE FOR IASPECTTON

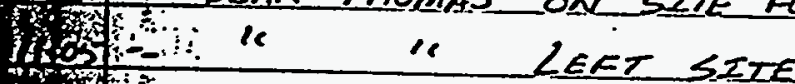

$=\div$

IIIS COLECTED HAND AUGER SOIL SAMPLE FROMI

2. CSGG-22-01 from o to $1 \mathrm{ft}$ BGS

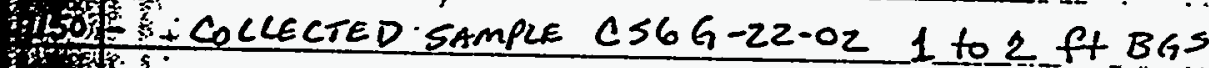

TLU TCOLECTED SOXL SAMPLE 2 to 3.5 ET BLS

.. Wh

\% AUGER REFusal \& 3.5 BGS- DID N.OT

1. PUGER JHROUGH THE BURN MATERIAL

IDZOE BRWEE KRISTIANSON ON SITE - HE HELPED

A SPECON / GENERAL STTE_CLEANUP - IDENTIFIED

1. STREAM SAMPLE SDCATIONS

IS. F POLECTED FIELD BLANK SAMPLE

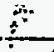

a 3 ,

LEFT SITE

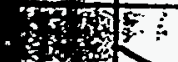

(1)

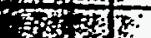

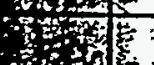

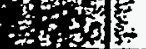

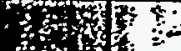

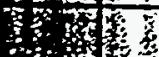

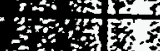

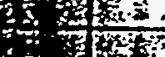

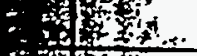

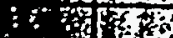

$\therefore$ is

.

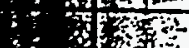

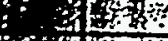

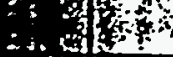

s.

Etrita

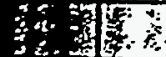

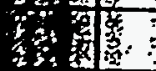




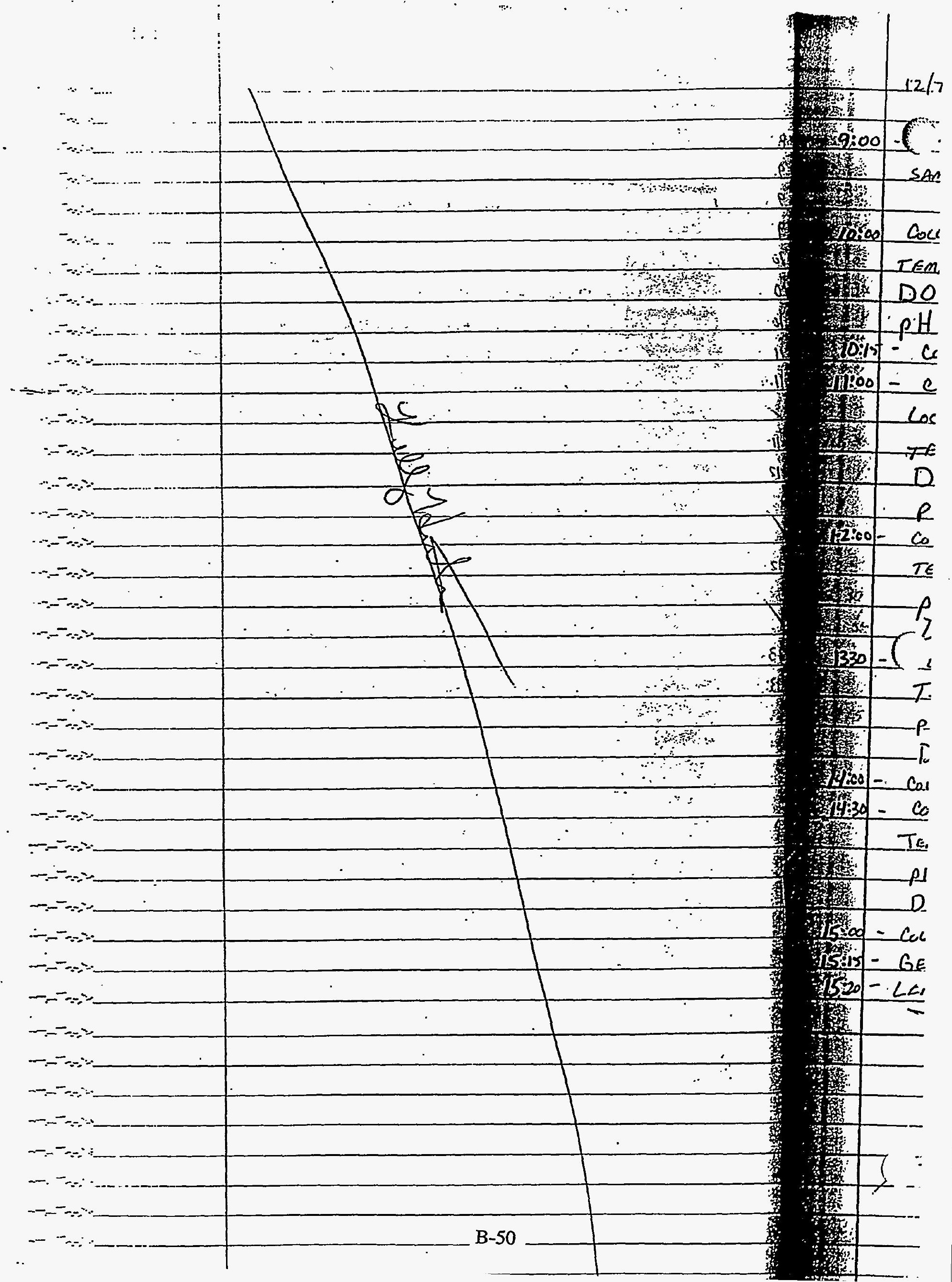




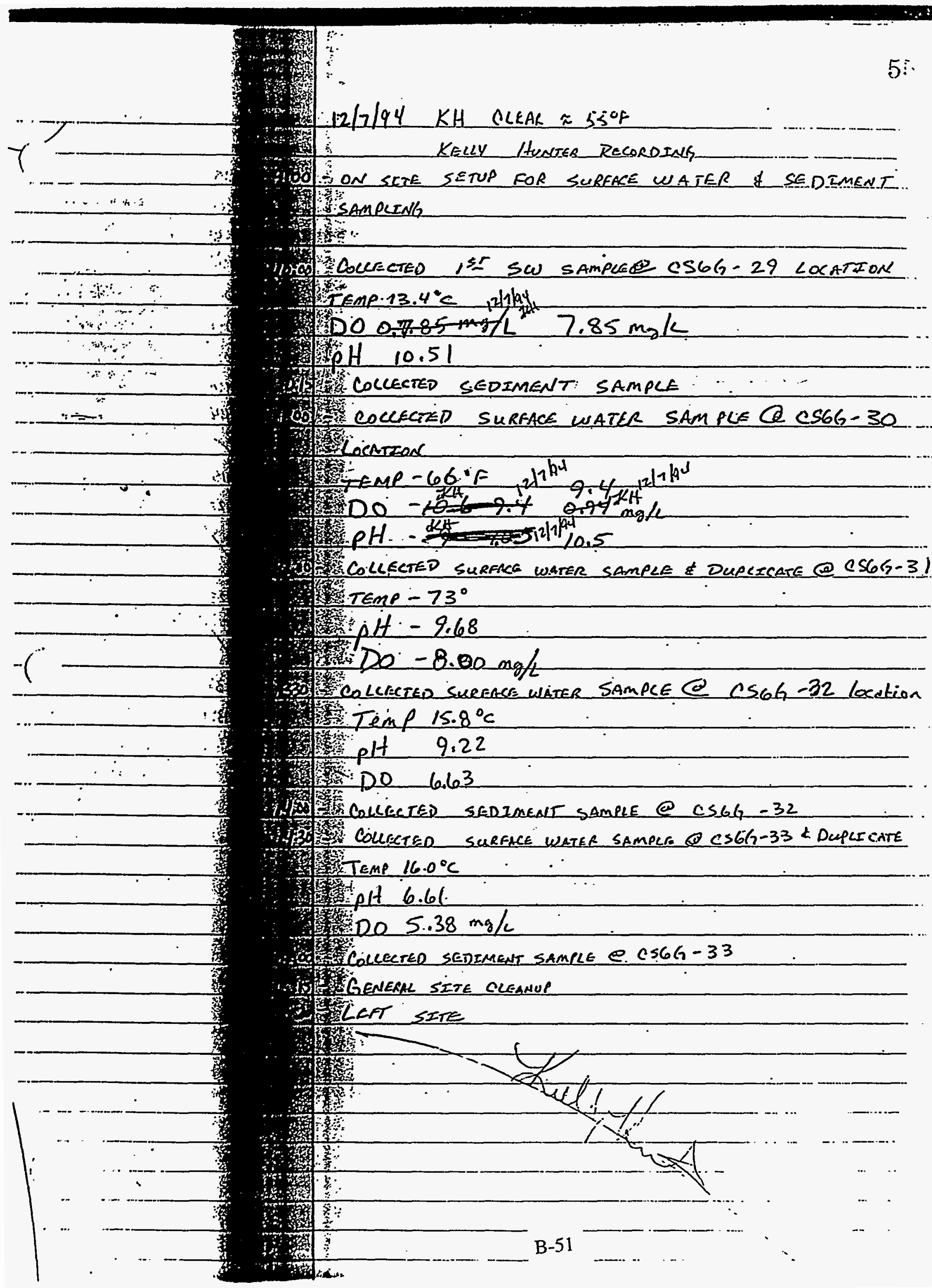




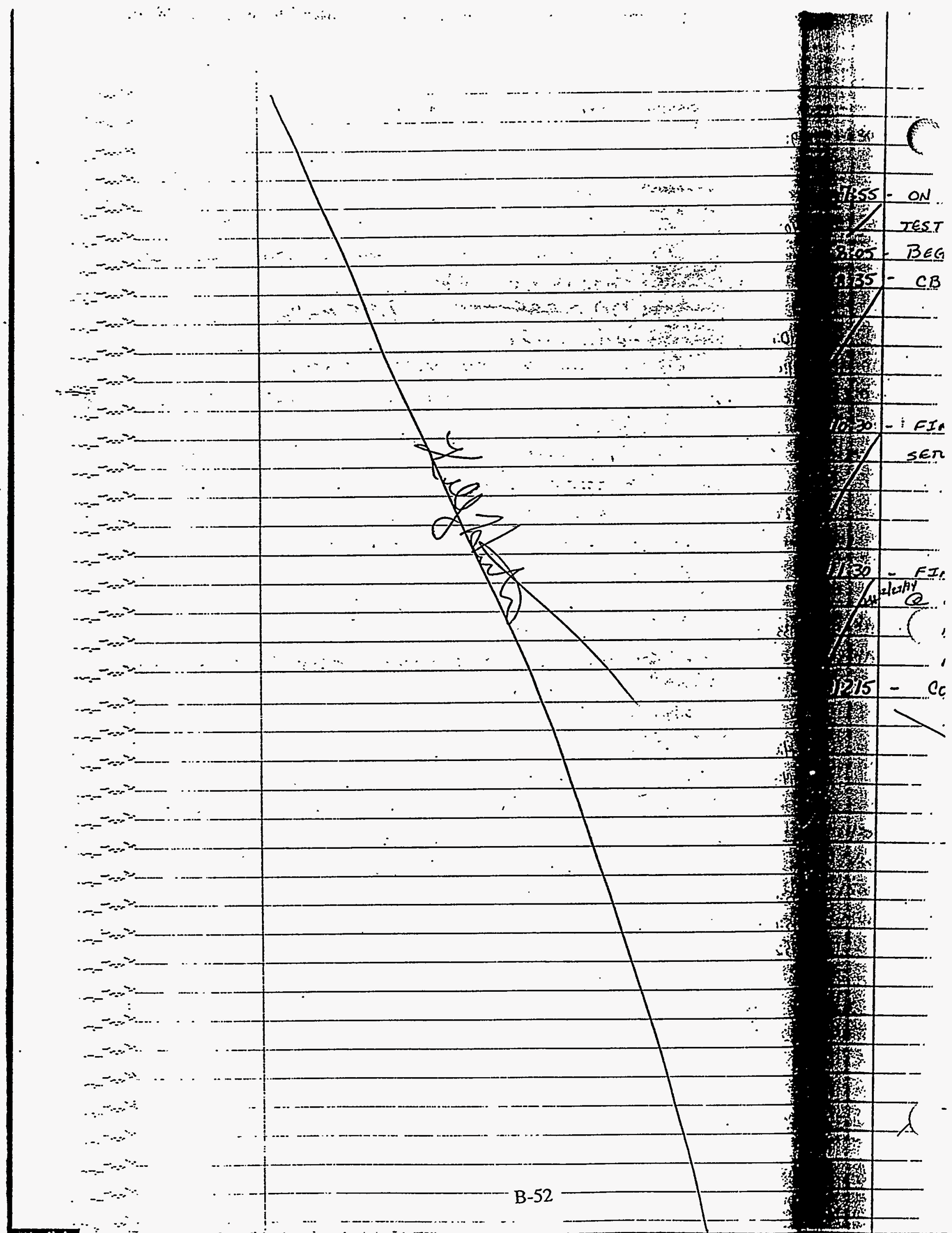




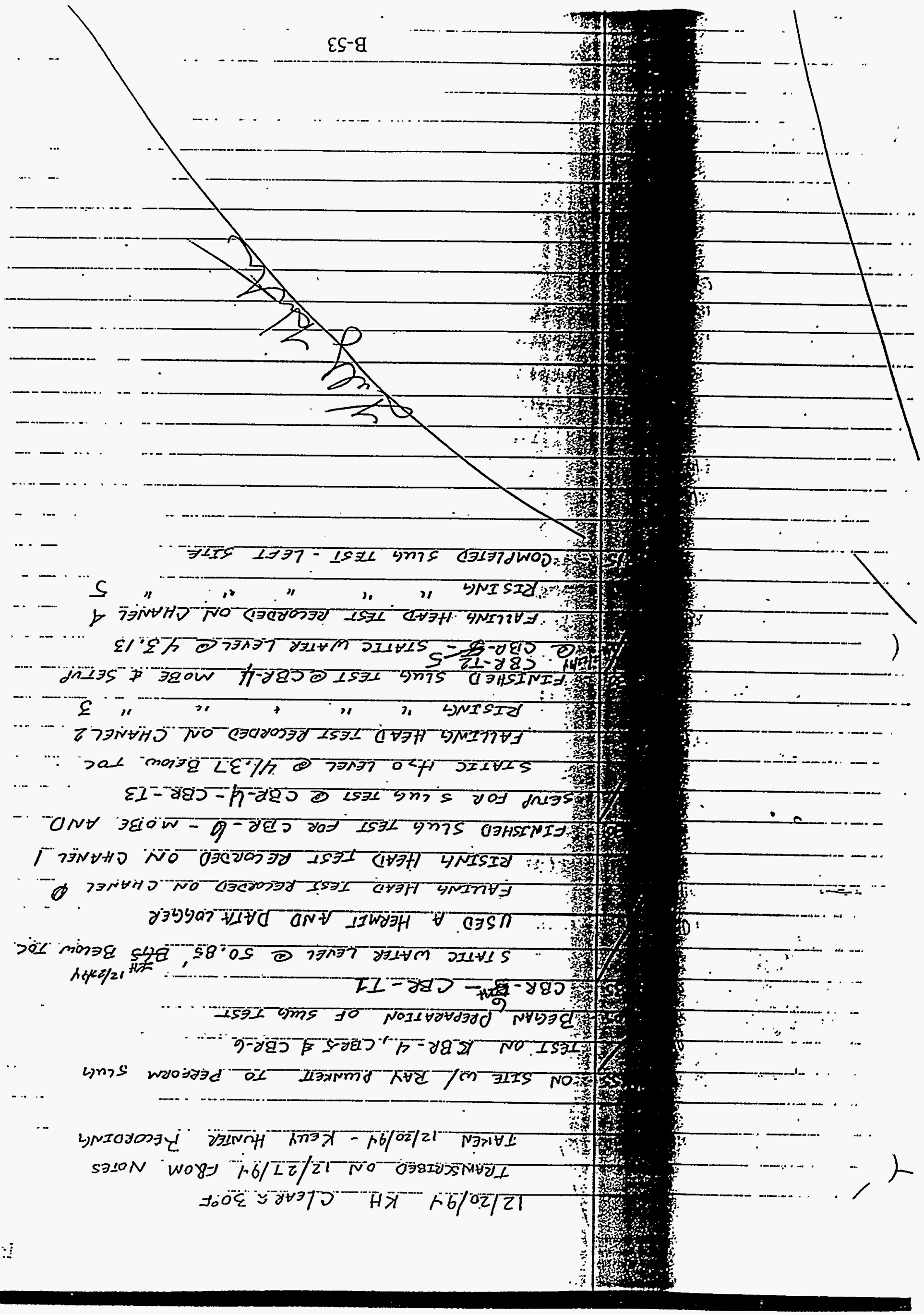




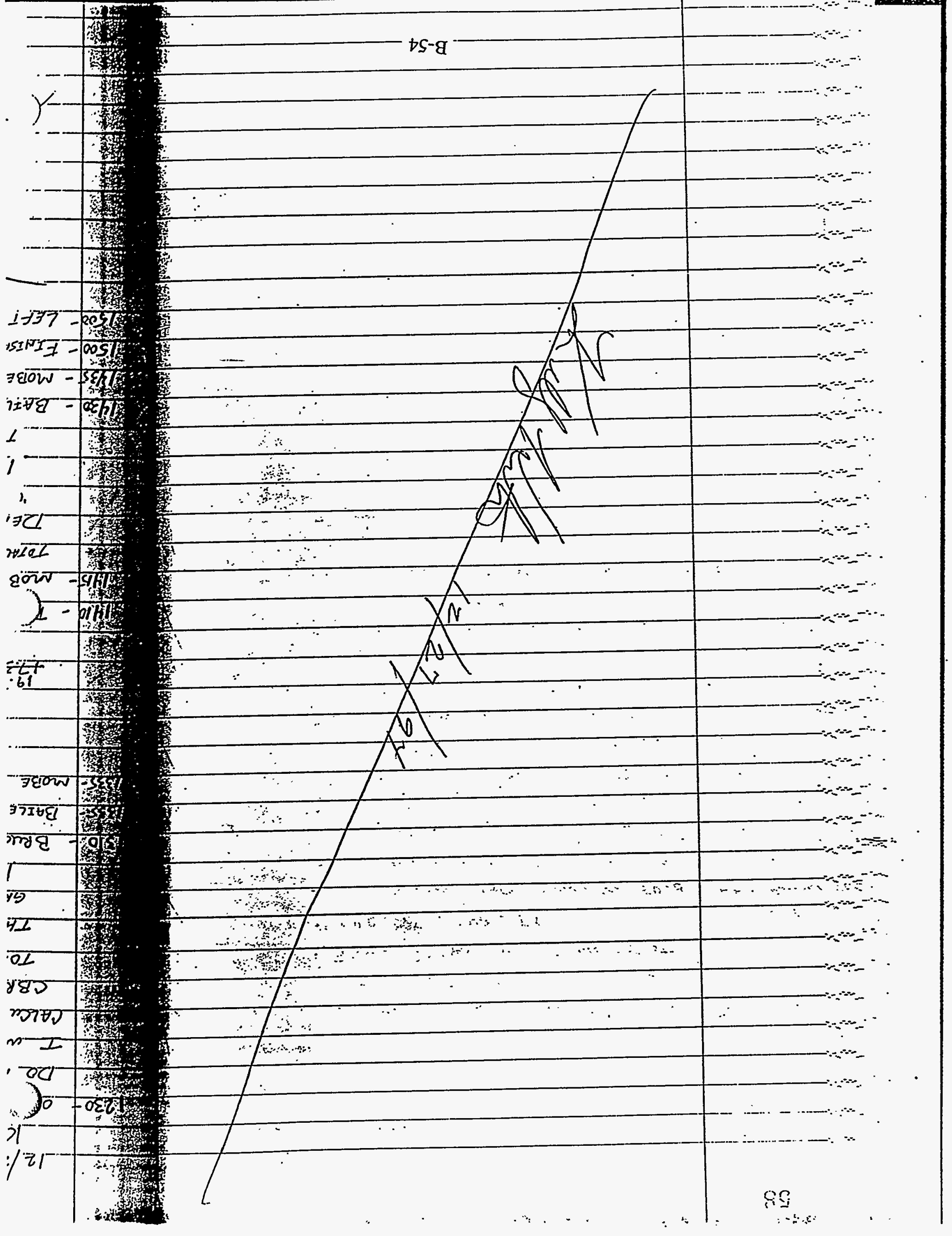




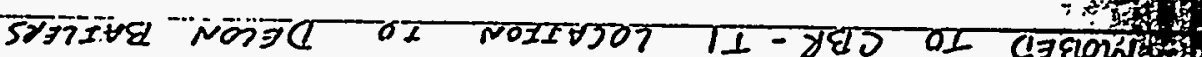

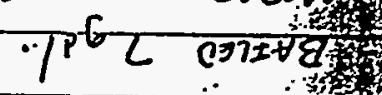

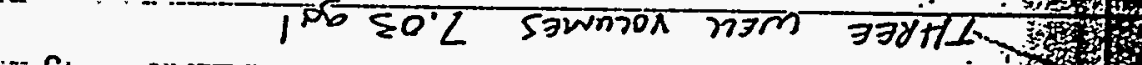
"PG

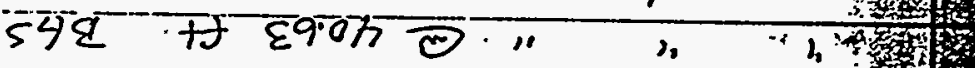

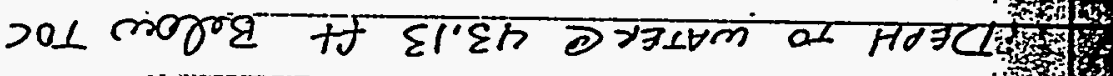

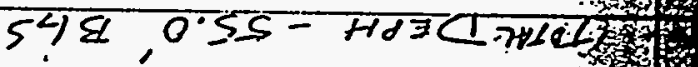
NOI Tib or

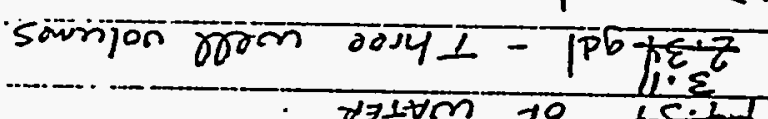

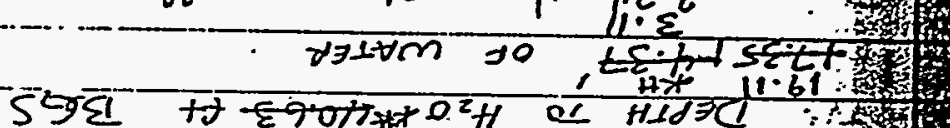

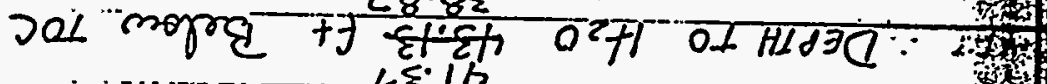
5) $156-9$ तजगाष्द्य

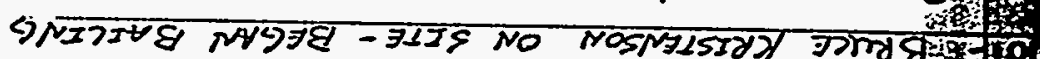

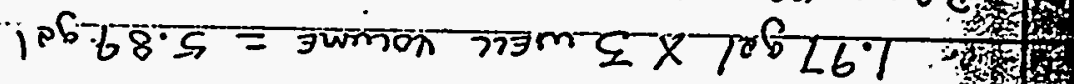
nэm Nì-

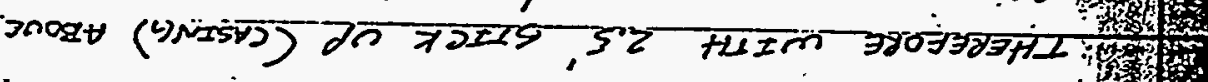

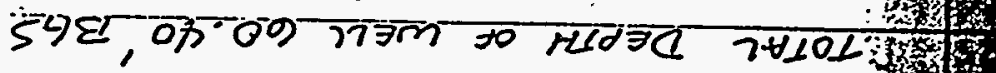

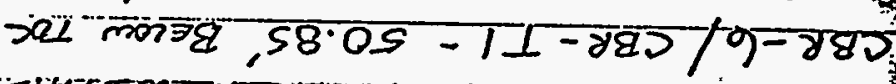

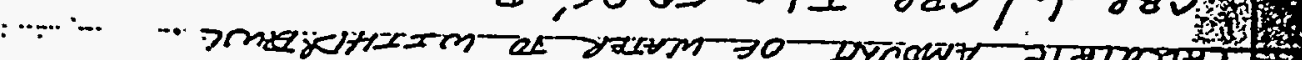

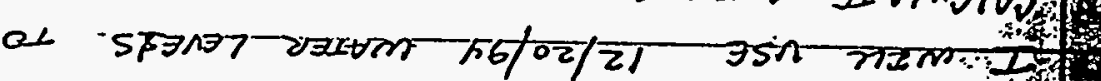

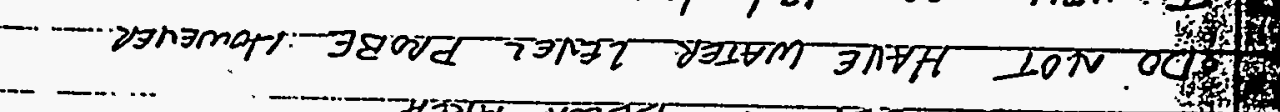

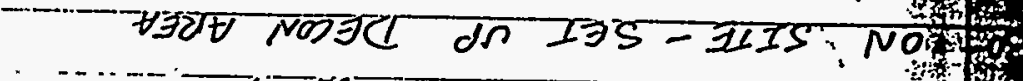

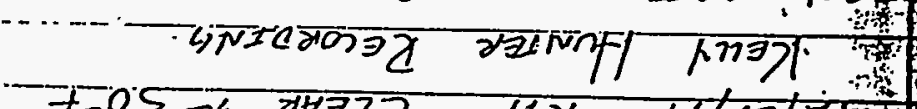

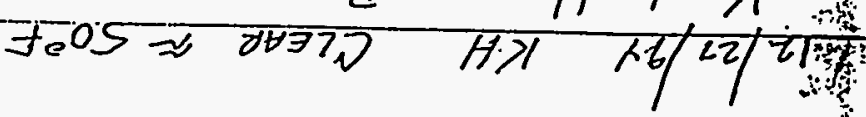

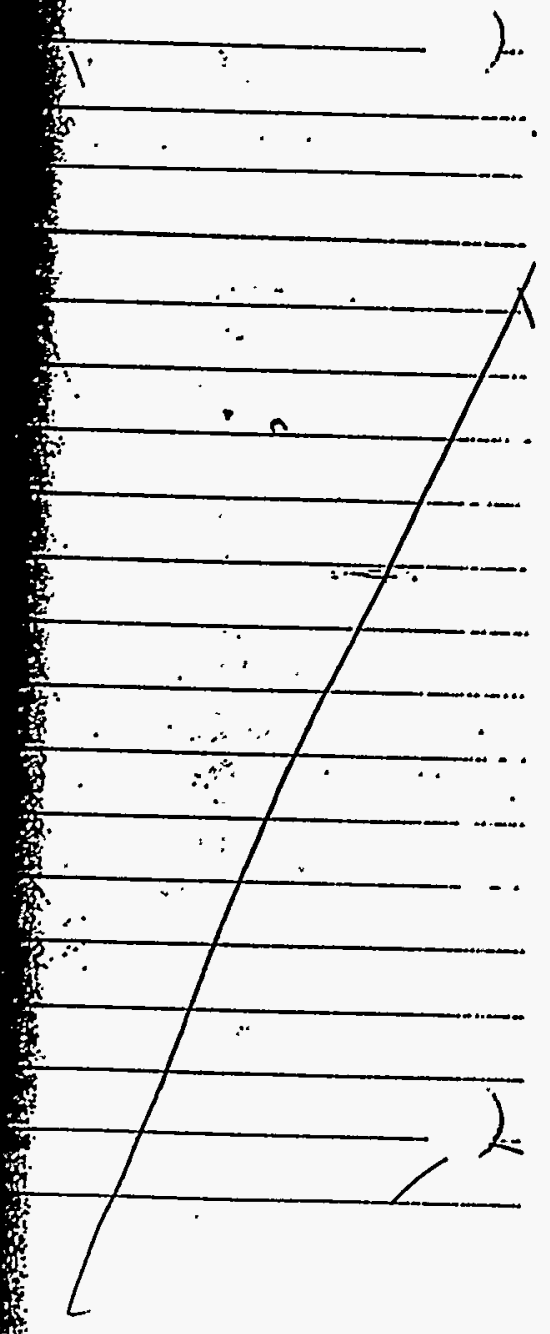




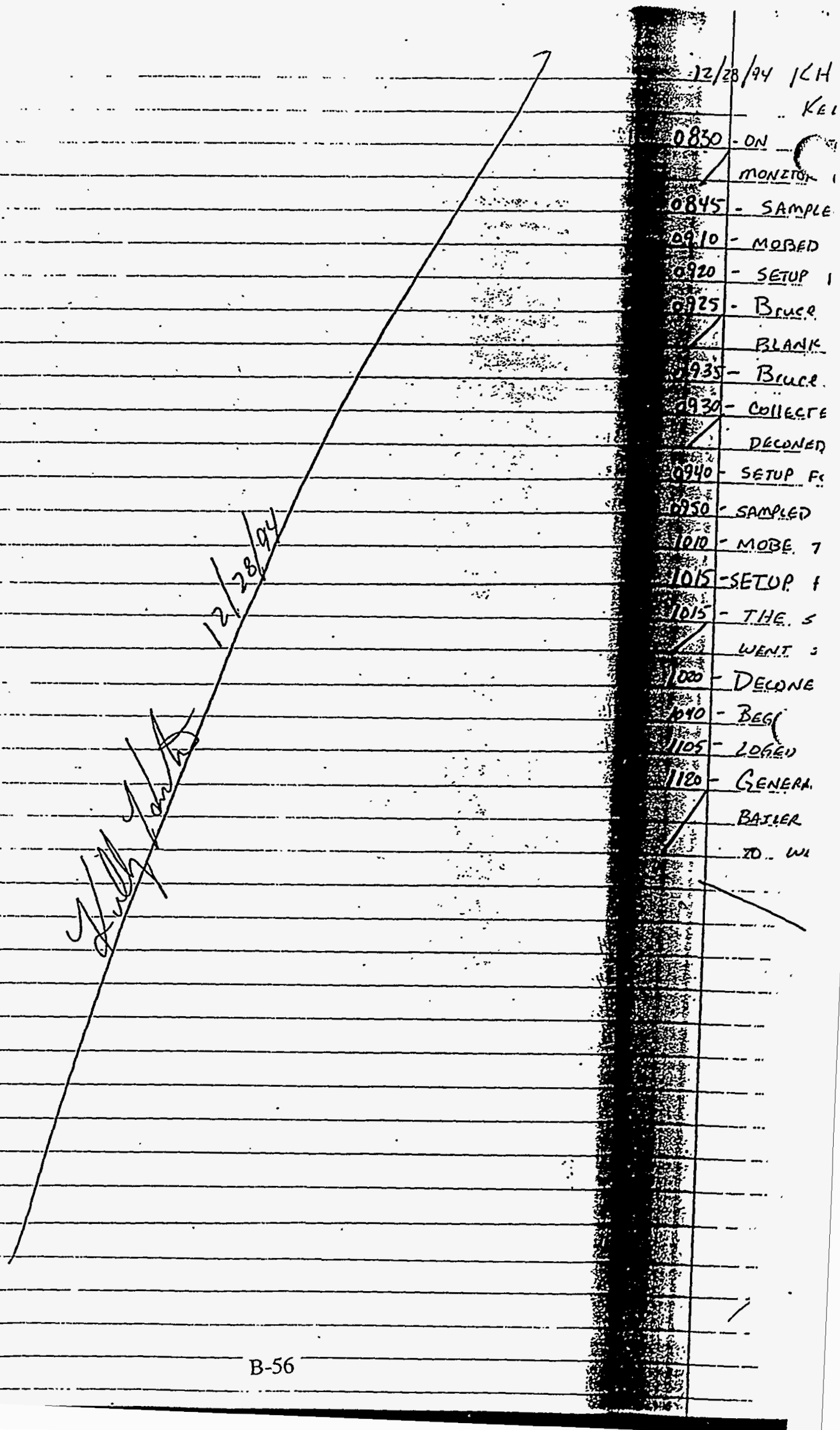




\section{Appendix C}

Field Reports for Groundwater Monitoring Wells
CBR-4
CBR-5
CBR-6 


\section{CBR-4}




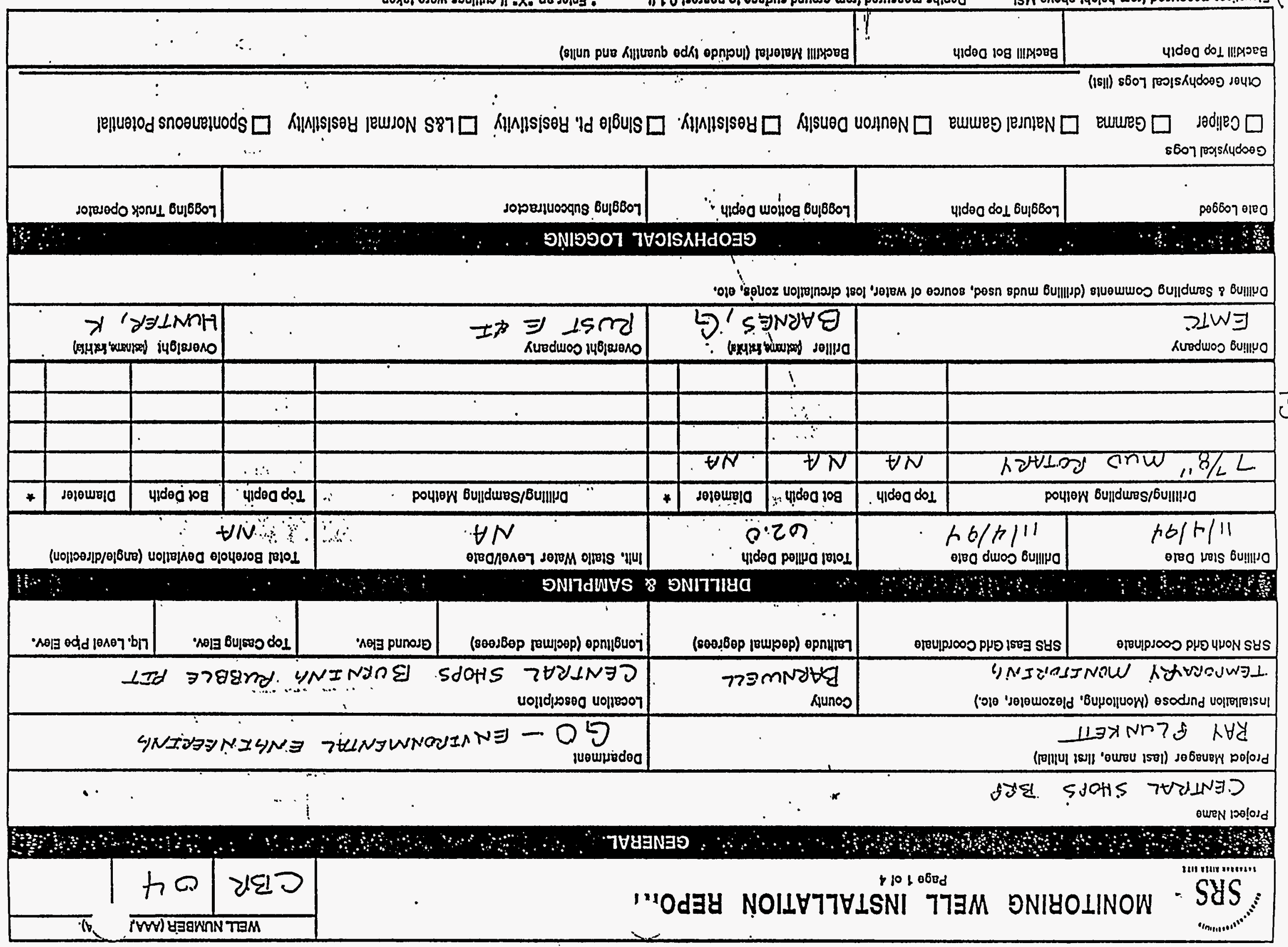




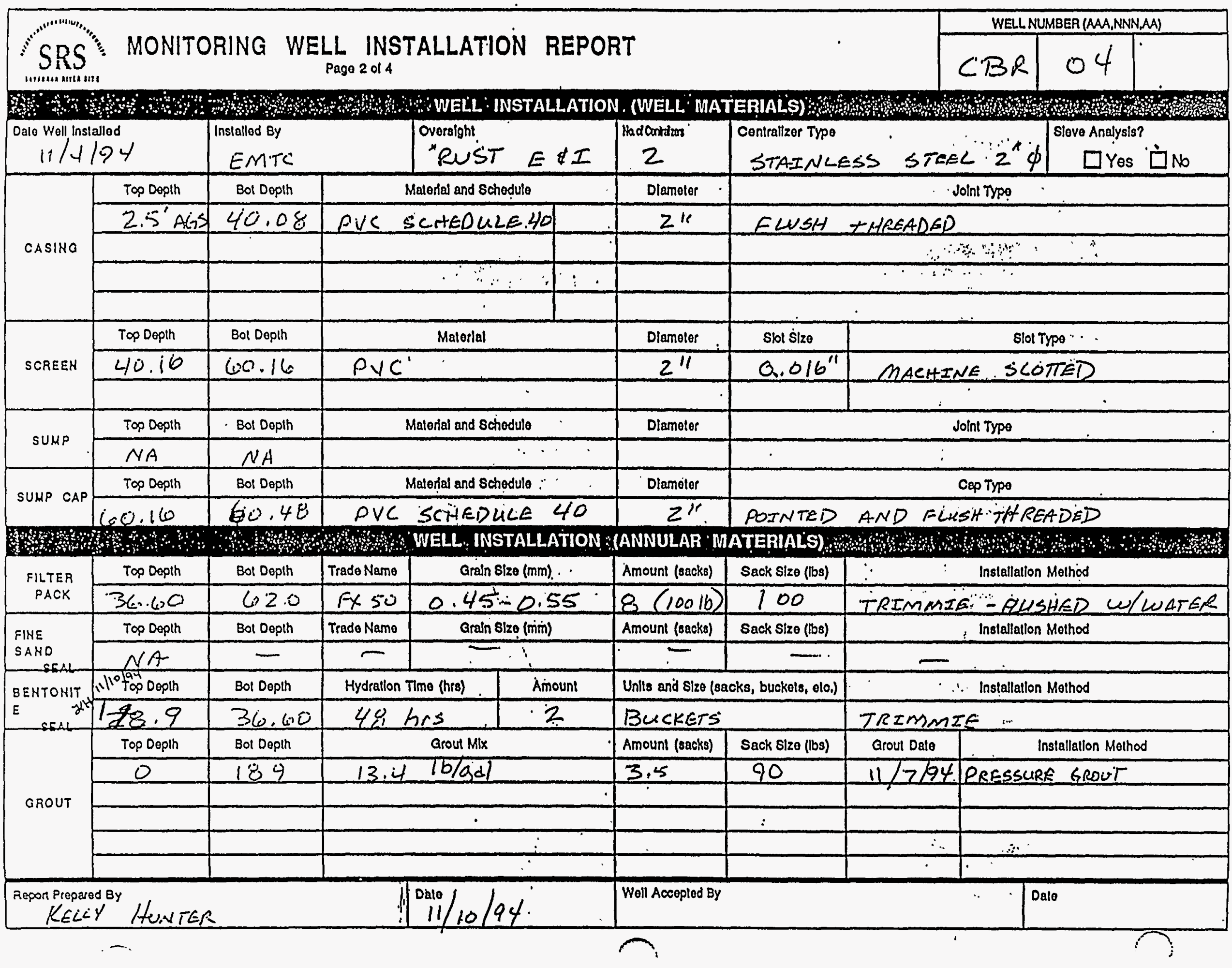


DRILLING SUBCONTRACTOR EMTC

D. in G. BARNES

DATE OF WELLINSTALLATION ..11/4/94

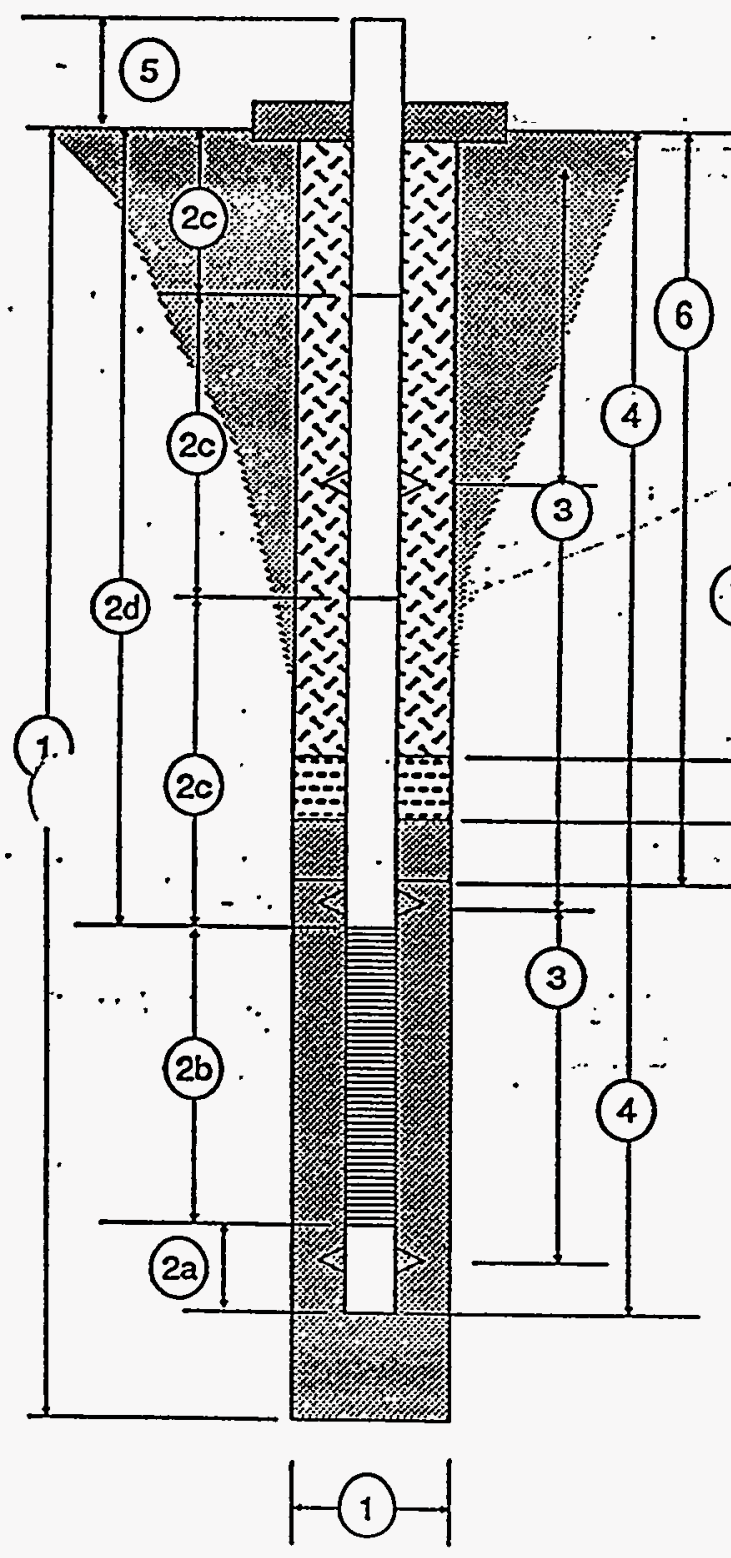

WELL NUMBER CBR-O4

SRS COORDINATES

SANITARY SEAL ELEVATION

NOTE: ALL MEASUREMENTS

ARE FROM GROUND

SURFACE AT START

OF - BORING - MEASUREMENTS

TO NEAREST 0.1 FOOT.

(9) 1) Total Drilled DepthHole Diameter $62.0 / 77 / 8$

2) Casing/Screen Tally (Measured to Nearest 0.01 Foot)

(a) Sump \& Plug Length 0.32

(b) Screen Length $\cdot 20.08$

(c) Casing Joint Lengths (Measured in Up-

hole Sequence From Top of Screen) $10.06,10.05$ $10.05,10.00,2.74$.

(d) Depth to Top of Screen $40,0.8$

3) Depths to Centralizers 19.0 क 39.0

4) Total Depth of Installed Well_ 60.48

5) Casing Stick Up (Standard 2.5' A.G.S.) 2.5

6) Depth to Top of Filter Pack 36.6

7) Depth to Top of Fine Sand Seal NA

8) Depth to Top of Bentonite Seal__ 18.9-48 has hydroted

9) Thickness of Grout $13.4 \mathrm{lb} / \mathrm{ge}$ 


\section{TOUTH CAROLINA DEPARTMENT OF HEALTH AND ENVIRONMENTAL CONTROL \\ Ground Watar Protaction Divtelon 2600 Bult streat \\ Columbla,8.C. 20201 \\ (103) 734.5212 \\ waler woll Record}

1. LCEATION OF WEL

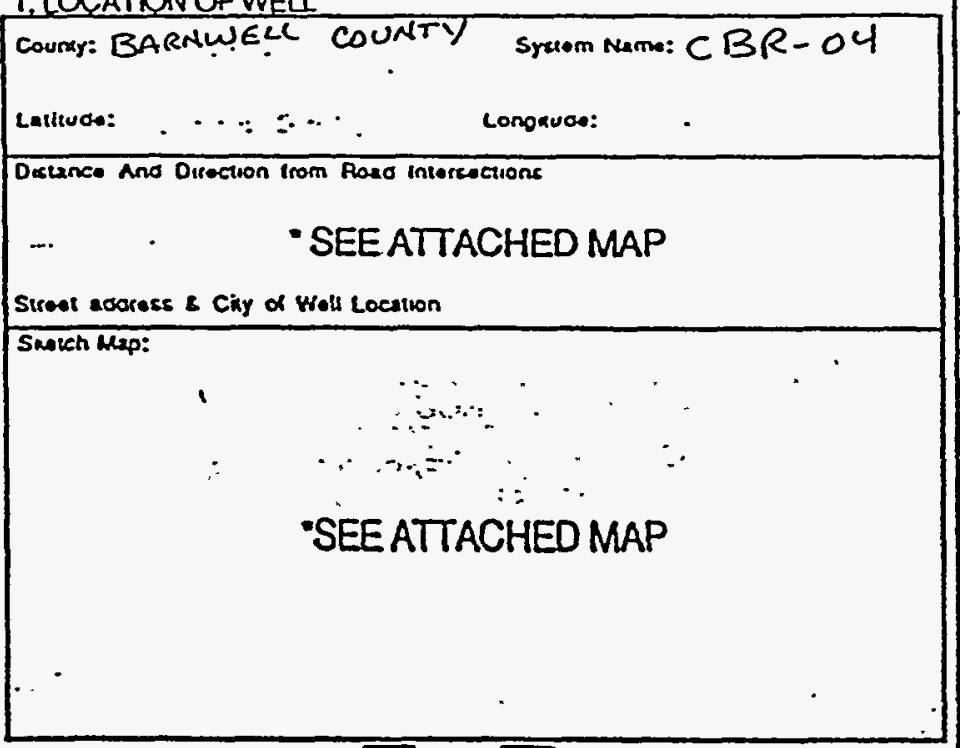

2. CUTTING SAMPLES

Geoptyrical Logs

X:] Yes $\square$

GYes (Please Enclose) $\square$ ib

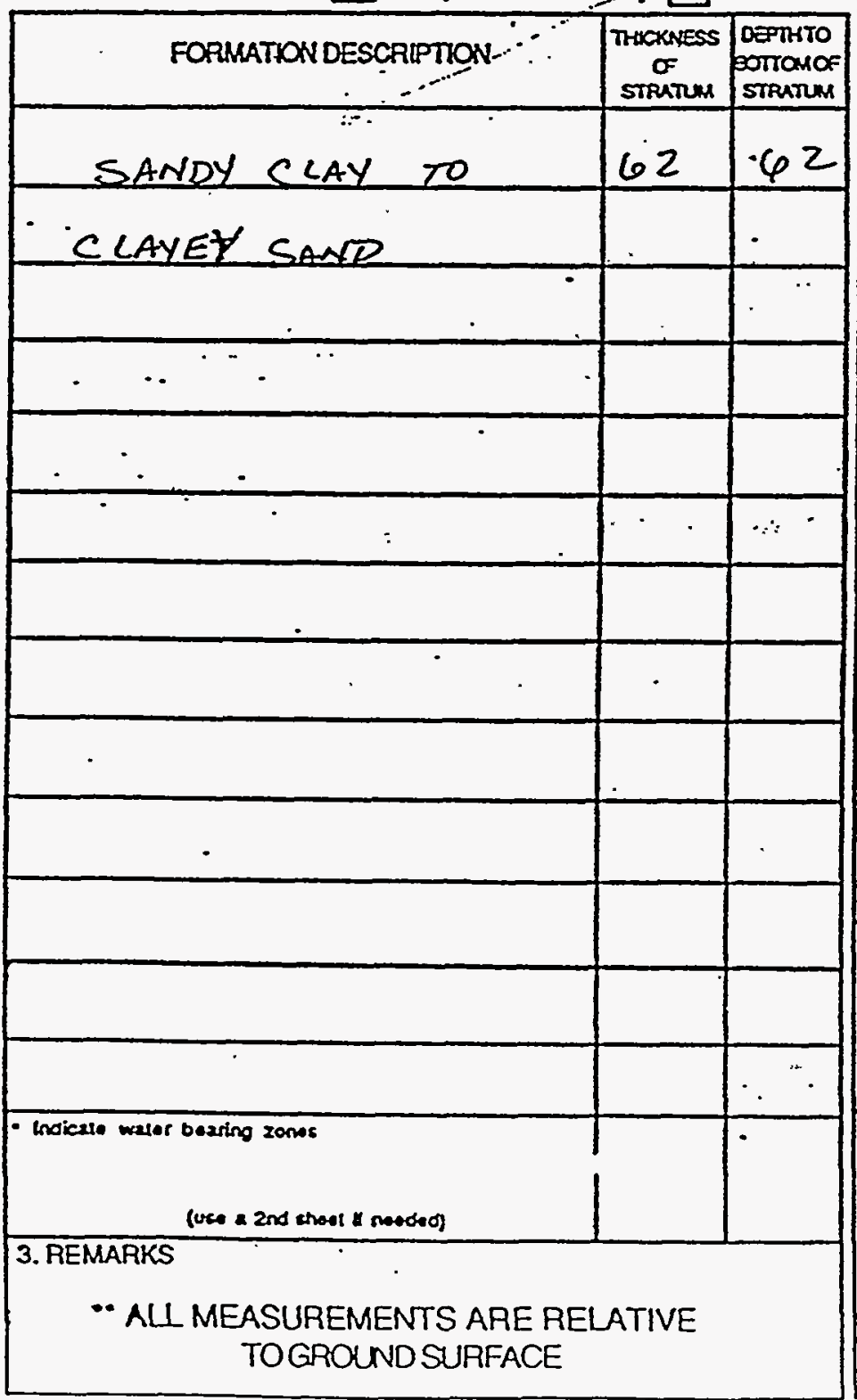

4. OWNER OF WELL:

Address

DEPARTMENT OF ENERGY

Tolopnone Ne

Engineor 2. L. JRkESEK

Addrece eLDS 75S-R, SRF

AIKEN, SC $2800 t$

Telophone No.

$952-7648$

5. WELL DEPTH (Completed)

60.48 i.

AIKEN. S.C. 2980

\section{DRILL METHOD MUD ROTRRY}

7. USE: MOKITOR WELL

Publc Supply-Permi No.

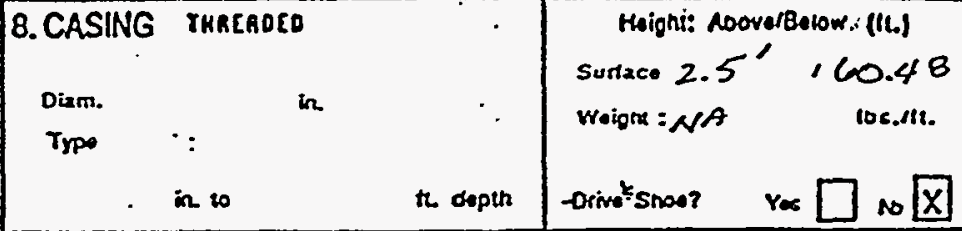

\section{SCREEN:}

TyP : P.VC

Slongauze 0.016

Dixm 2

in.

Set Bormoen 40.16 th and 60.16 it. NOTE: MULTRLE SCREEHS

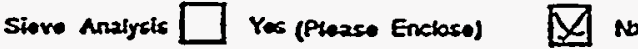

10. STATIC WATER LEVEL

41.20 th. below land surface after 24 hours

11. PUMPINGLEVEL Below Lend SUrnaco

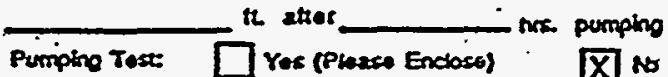
GPH

ruls

12. WATER QUALTY

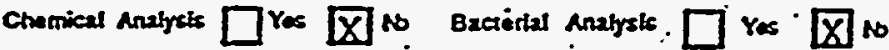

Plazes Encloce las Protos

13. ARTIFICLAL FUTER fGrevel Pact $[X]$ Yo $\square \mathrm{No}$

tnetalled trom .62 .0 th to $36.60 \mathrm{tt}$.

Ellective cize $-45-.55 \mathrm{~mm}$ untormhy contlicions < 1.7 .

14.WELlL GROUTED? $X$ YeS $\square$ Nb :-

NEAT CEMENT, GZ IENTONITE

Depth From 0.0 ft. to $23.60 \mathrm{ft}$.

15. NEAREST SOURCE OF POSSBBLE CONTAMINATKON: ___"___ diroction WeA disiniectod $\square$ Yes Type Type upon comptetion $\bar{X}$ is amoun

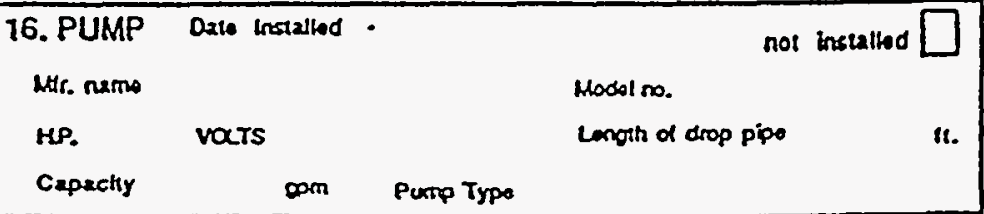

17. WATER WEUL CONTRACTOR'S CERTIFICATION: This woll w2s dilled under my disection and thic repont is true to the bert of my knomledge and bellal. REGISTERED ENATC ADORESS BuSWESS

CERT.NO

Sionod लn+0ize

DaK 
PAGE $\angle$ OF 22

NFRASTRUCTURE

CLIENT WSRC

("ROJECT CENTRAL SHOPS BRP

SUBJECT Well Construction Prepared By. Kelf Ydate _e/ $/ 4 / 9$ Reviewed By _ Date Approved By

Date

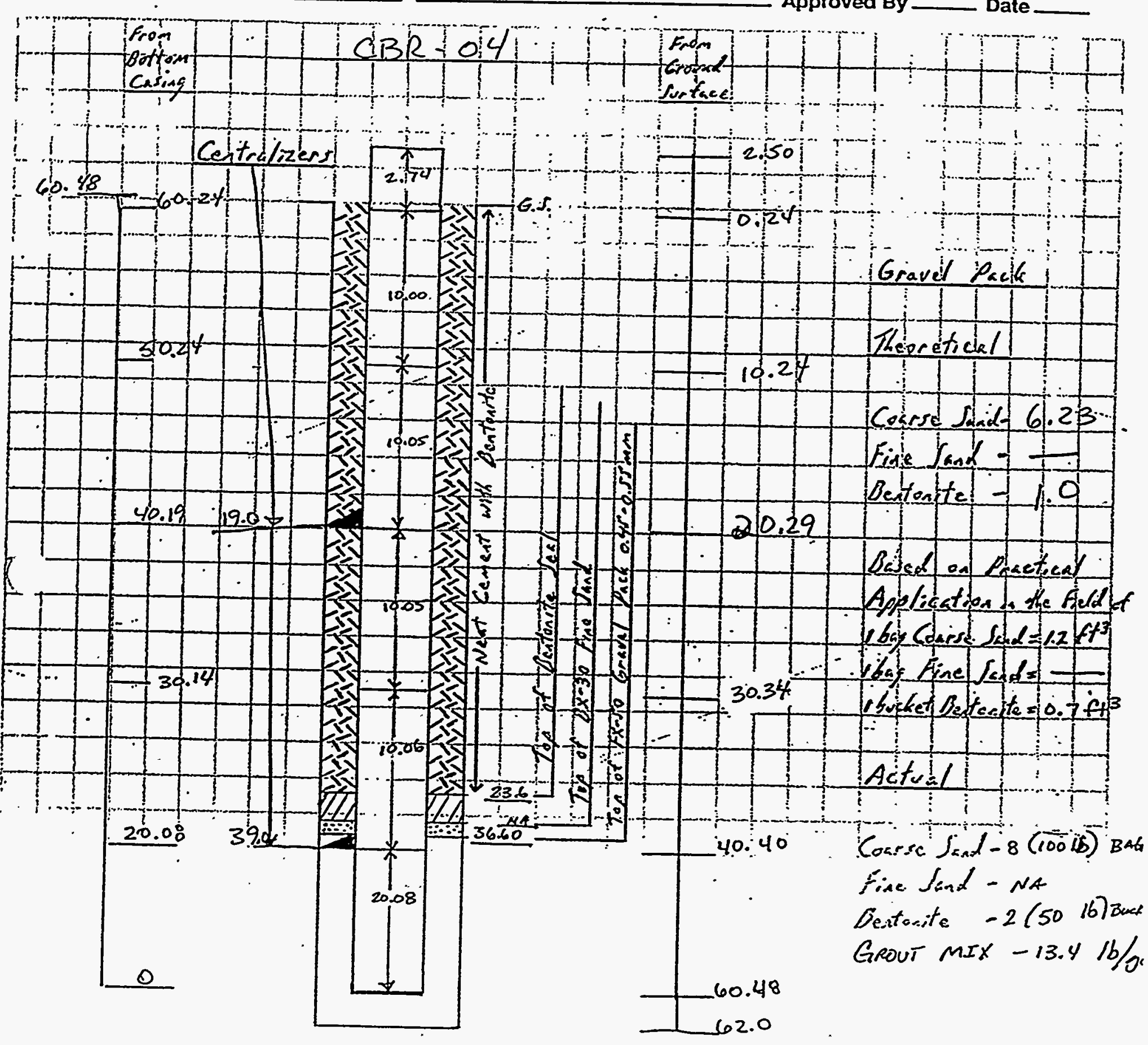




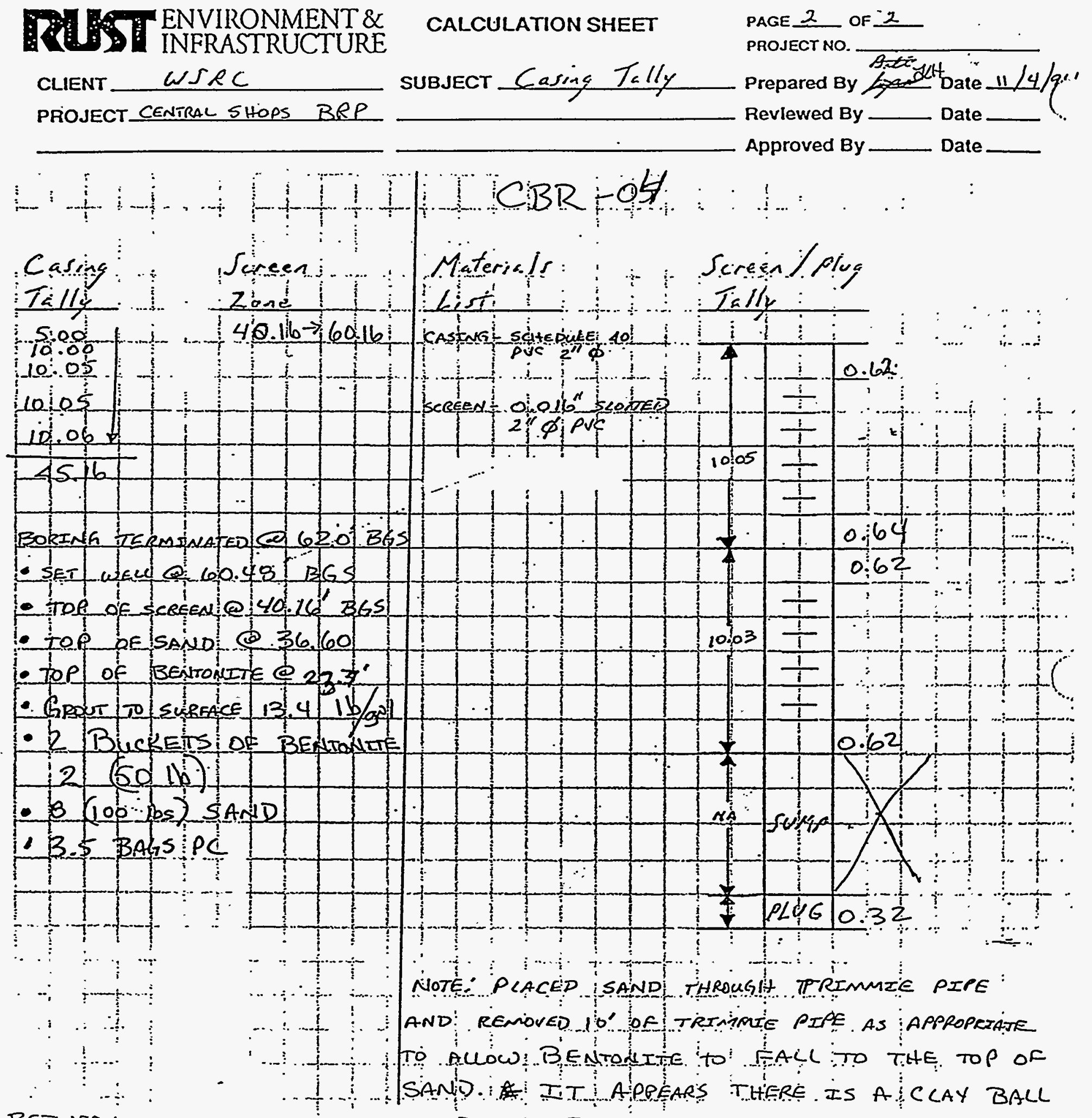

BETWEEN THE TOP OF THE SAND AND THE BOTTOMZ.OF THE TRIMMMIE PIPE. THE BENTONITE WAS. GO 27.5' BGS, ZHERERORE LEAVING AN APPROXIMATE

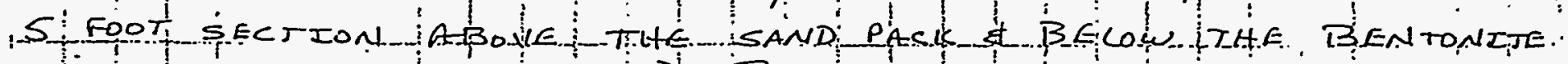
SEAL WITHOUT A SAC (VOID). BECAUSE I HAS IS: A. PIELOMETER AND OCCURED APPROXIMIATEV 10 FEET ABOVE THE WATER TABLE WE ADDED AN ADDITIONAL BUCKET OF BENTONITE TO ENSURE AN ADEQUAT. SEAL EXIST TO AVOID INTRUSION OF CEMENT GROUT, TOP OF BENTONTEE@23.6' BES.

C-6 
TIT ENVIRONMENT\&

CALCULATION SHEET

PAGE 1 OF 1

CLIENT WSRC

SUBJECT WELC CONSTRuCTESPrepared By $\ll$ H Date $\mu / 4 /:$

PROJECT CENTRAL SHOES BAP Reviewed By

Date __

Approved By

Date __

Theoretical:

$$
C B R-04
$$

CoARSE SAND

BOREHOLE DEA METER - 7.875

Boretroce DEBrA -.62

SET w Eu e- 40.48

TOP OA SAND (THEORerzCAC) 38. 48

ONE BAG OF SAND $(100 \mathrm{lb})=1.2 \mathrm{ft}^{3}$

$$
\begin{aligned}
& V=\pi r^{2} f-1 \\
& V=\pi\left(\frac{3.94}{12}\right)^{2}(23.52)-\pi\left(\frac{1}{12}\right)^{2}(22) \\
& V=7.48 \mathrm{ft}^{3} \text { or } 6.23 \text { BASS OF SAND (100.16; }
\end{aligned}
$$

BentonITE

$$
\begin{aligned}
& \left.V=\pi r^{2} h=\pi\left(\frac{3.94}{12}\right)^{2}(2)-\pi\left(\frac{x}{12}\right)^{2} / 2\right) \\
& V=0.6337 \mathrm{ff}^{3}, \\
& \therefore-1 \text { Bucket BentonITE }
\end{aligned}
$$

C-7 


\section{(}

CBR-5

( 


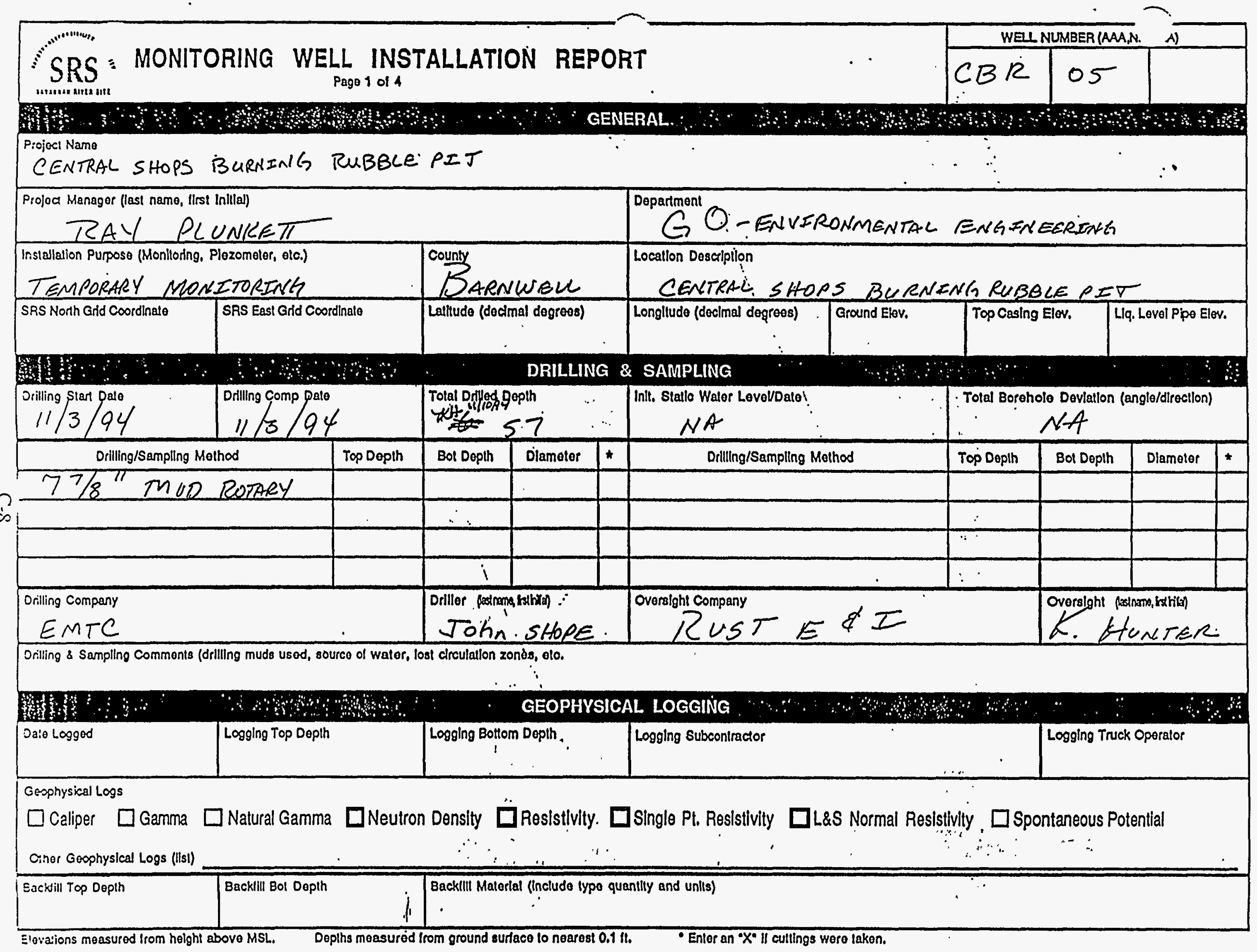




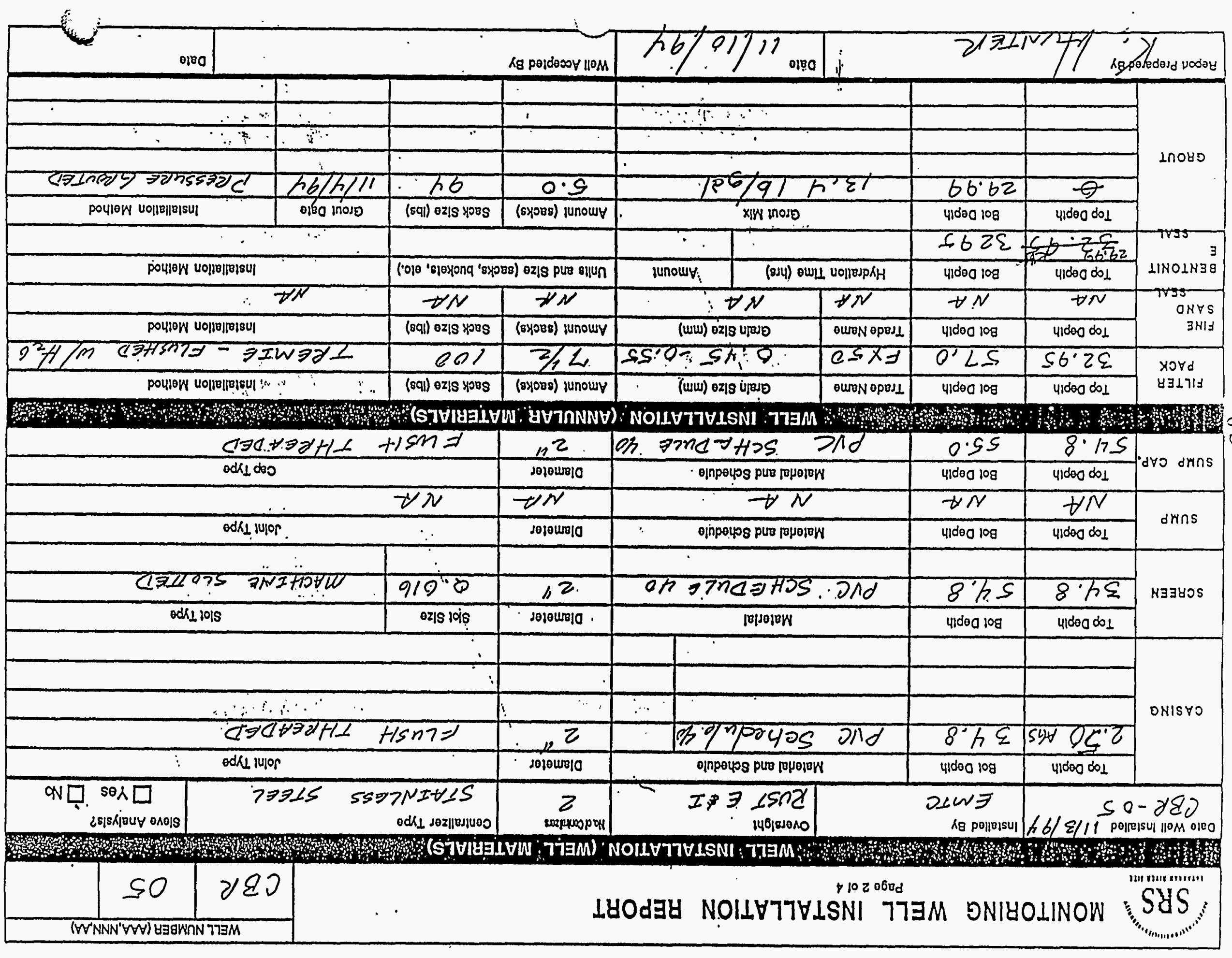


DRILLING SUBCONTRACTOR EMTC.

C LER John Shope

Date of WELIINSTALATION: $11 / 3 / 94$
WEU NUMBER CBR -05

SRS COORDINATES

SANITARY SEAL ELEVATION

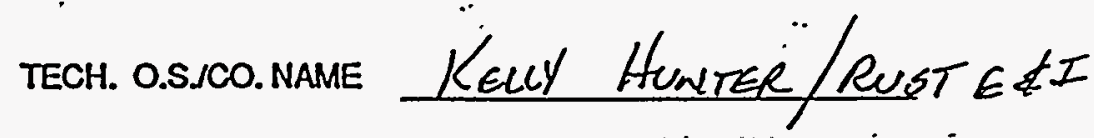

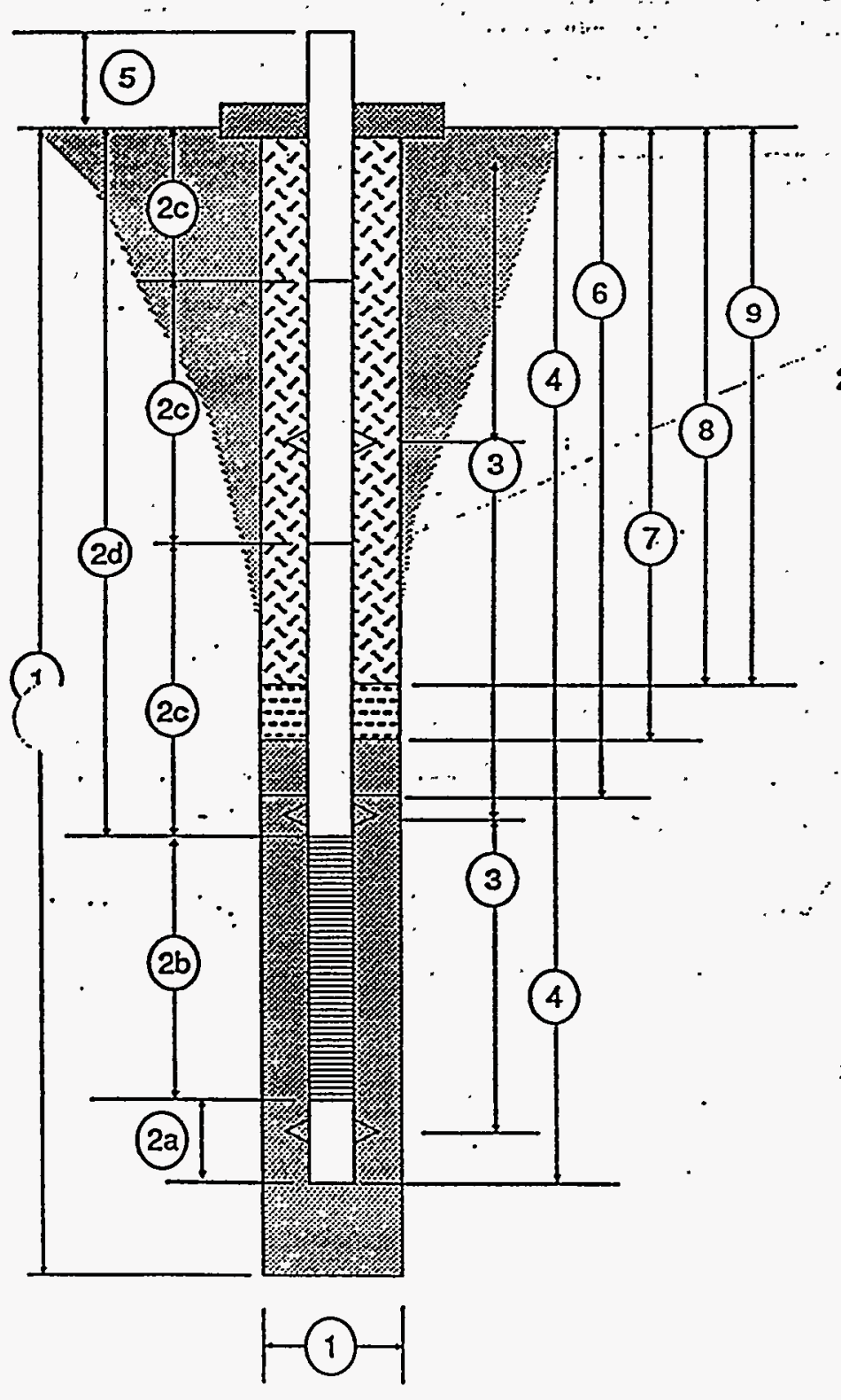

\section{NOTE: ALL MEASUREMENTS \\ ARE FROM GROUND \\ OF BORING-MEASUREMENTS \\ TO NEAREST 0.1 FOOT.}

1) Total Drilled Depth/Hole Diameter 57

2) Casing/Screen Tally (Measured to Nearest 0.01 Foot)

(a) Sump \& Plug Length 0.20

(b) Screen Length . 20.0

(c) Casing Joint Lengths (Measured in Uphole Sequence From Top of Screen)

$10.0^{\circ} 100,10 ; 5.00,2.50$

3) Depths to Centralizers 15.0 \& 29.0

4) Total Depth of Installed Well 55.0

5) Casing Stick Up (Standard 2.5 A.G.S.) 2.5 AGS

6) Depth to Top of Filter Pack 32.95

7) Depth to Top of Fine Sand Seal n N A

8) Depth to Top of Bentonite Seal__ 29.99

9) Thickness of Grout $13.41 \mathrm{~b} / \mathrm{gd} /$ 
SOUTH CAROLINA DEPARTMENT OF 1. LOCATION OF WEUL

Coumy: BATRNWEUL Syenom Nama: CBR - OS

Latituos: Congavas:

Destance And Orsecton trom fiond Intersections

\section{- SEE ATTACHED MAP}

Stroet adoress \& Ciy of Wall Lacation Sinich Mep:

\section{-SEE ATTACHED MAP.}

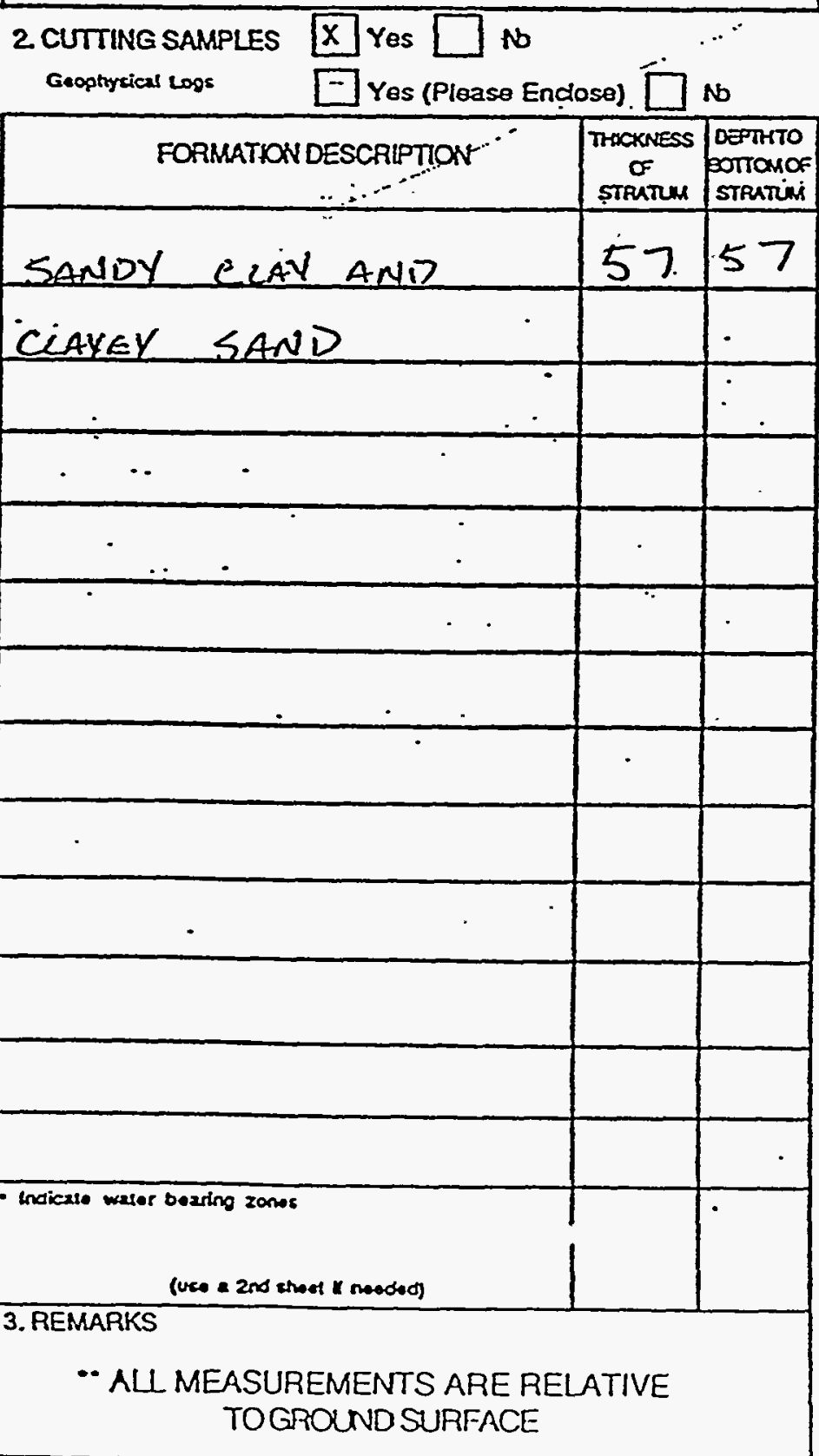

HEALTH AND ENVIRONMENTAL CONTROL Columbla,s.c. 20201 (803) 724-5212 Wales Woll Recors 4. OWNER OF WEU: nodeses DEPARTMENT OFENERGY AIKEN. S.C. 29801

Teloprone NC

Enginaer 2. L. JaksstN

AdOrecE BLDG 75S-R, SRE AIKEK, SC 28301

Tolophon two. $952-7648$

5. WELL DEPTH (Completed)
. 55 ".
Dasu completed: $11 / 3 / 94$

Dase sund: 11 T5/ad

6. DRILL METHOD MUD ROTARY

7. USE: MOKITOR WLLL

Puble Supply-Pormit No.

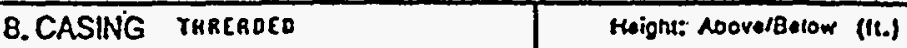

Diam. $2^{\prime \prime}$ in

Trpe $P \vee C$

in to 34.8 th depth Dive snoer ros $\square$ no $x$

\section{SCREEN:}

Trpo: $P J \mathcal{K}$

Slovgauze 0.016

in.

Sot Botwoen 55 it and 3.5

Diam 2

in.

Sieve Aralycks $\square$ Yos (Ptezso Enctose)

11. HOTE: HULTIPLE SCREENS USE SECOND SHEET

10. STATIC WATERLEVEL

- It below land surface after 24 hours

11. PUMPINGLEVEL Bolow Lend SUnzec

It atter GPL!

Pumpho Test: $\square$ Yos (Phese Endoses) $[X]$ No

Ylok

12 WATER QUALTYY

Chomical Analycts $\left.\square^{\text {Yos }}\right]^{\text {no }}$ Bxcaitial Anafysts $\square$ Yos $[X]^{\text {is }}$

Piesse Endose Les Rosutts

13. ARTIFICIAL FILTER Gravel Pack $[x]$ Ye $\square$ is

Inctutted tram 57 th to 32.95 t.

Elective size $.45-.55 \mathrm{~mm}$ unthormity collicions < 1.7 .

14.WEUI GROUTED? X Yes $\square \mathrm{Nb}: \ldots$

NEAT СЕMENT, 62 DENTONITE

Depth From 0.0 it. to $29.99 \mathrm{ft}$.

15. NEAREST SOURCE OF POSSIBLE CONTAMINATION:

1t. direction
Type Kel disinfectod DYes Typo upon comptation $X$ is Amoun

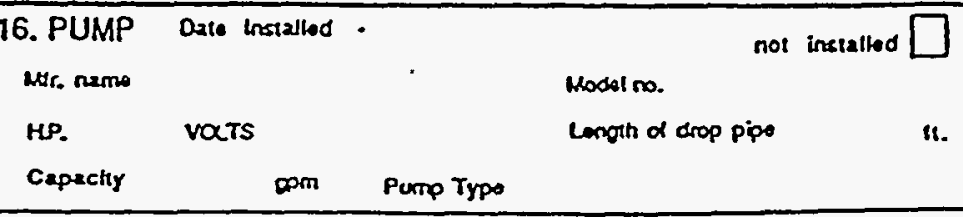

17. WATER WELL CONTRACTOR'S CERTIFICATION: This woll was oflled undor my direcion and this saport is twe to the bect of ing knowlodge and boltel. RBGGSTERED EMTC NDORESS PUSTE

CERT.ND

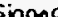

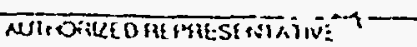

Dale, 


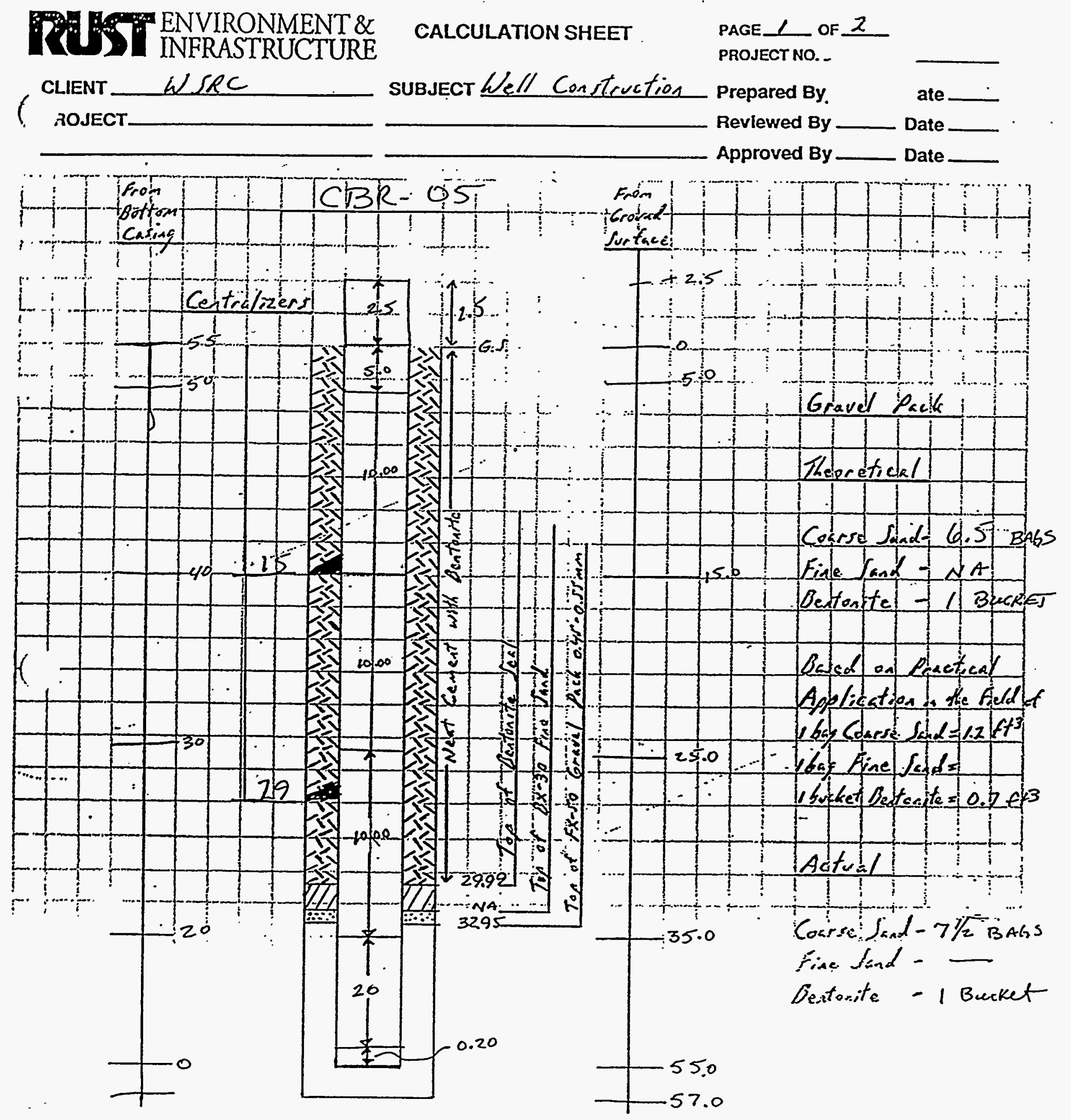

BORING TERMENATED $57^{\prime}$ BSS

SET BOTION OF wEU/ PLUG \& $55^{\prime}$ BGS

C-12 
PISTENVIRONMENT\& INFRASTRUCTURE

CLIENT WSRC

PROJECT

要
CALCULATION SHEET SUBJECT Casing Tally
PAGE 2 OF 2

PROJECT NO.

Prepared By Gye Date

Reviewed By __ Date

Approved By _ Date

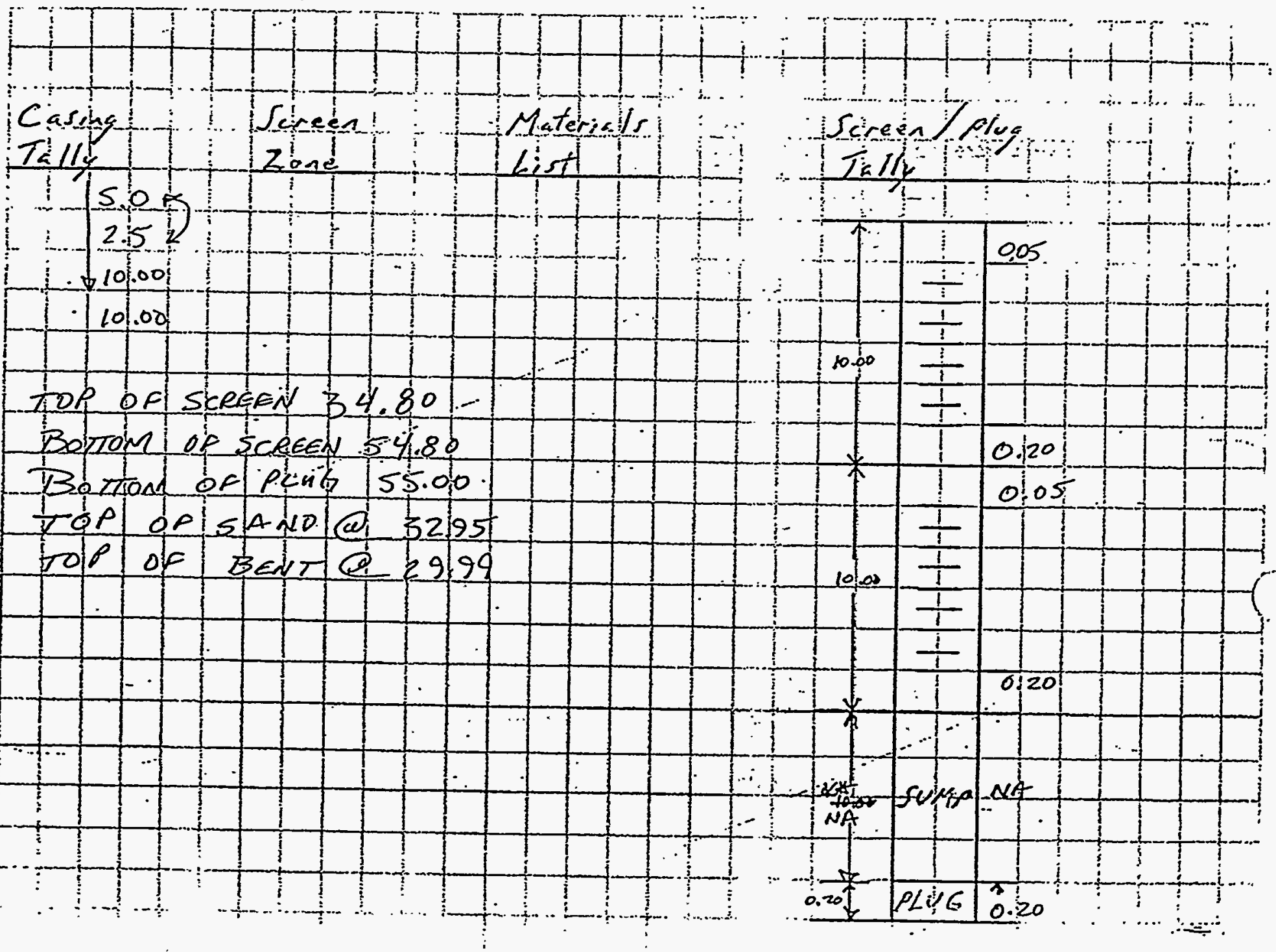


ENVIRONMENT \&

INFRASTRUCTURE

CLIENT WISC

PROJECT CENTRAL SHOPS BP
CALCULATION SHEET

SUBJECT WEU CONSTRucrepfopared By KAt Reviewed By Approved By
Date Uly/g,

Date

Date

$C B R-05$

Theoretics/

COARSE: SAND

BOREHOLE DIAMETER 7.825
DEPTH 57 SET WEN $55^{\prime}$

- TOP OE. SAND (TIHEOPETICAC) $32.8^{\prime}$

- one bag of SAND) $(10016)=1.2 \mathrm{fH}^{3}$.

$v=\pi r^{2} h$
$v=\pi\left(\frac{3.94}{12}\right)^{2}(24.2)-\pi\left(\frac{1}{12}\right)^{2}(2 i .2)$

$V=\pi(2.61)-\pi(0.154$

$V=7.71 f^{3}$ OR $=6.4$ BAGS of SAND

C- 14 
CBR-6 


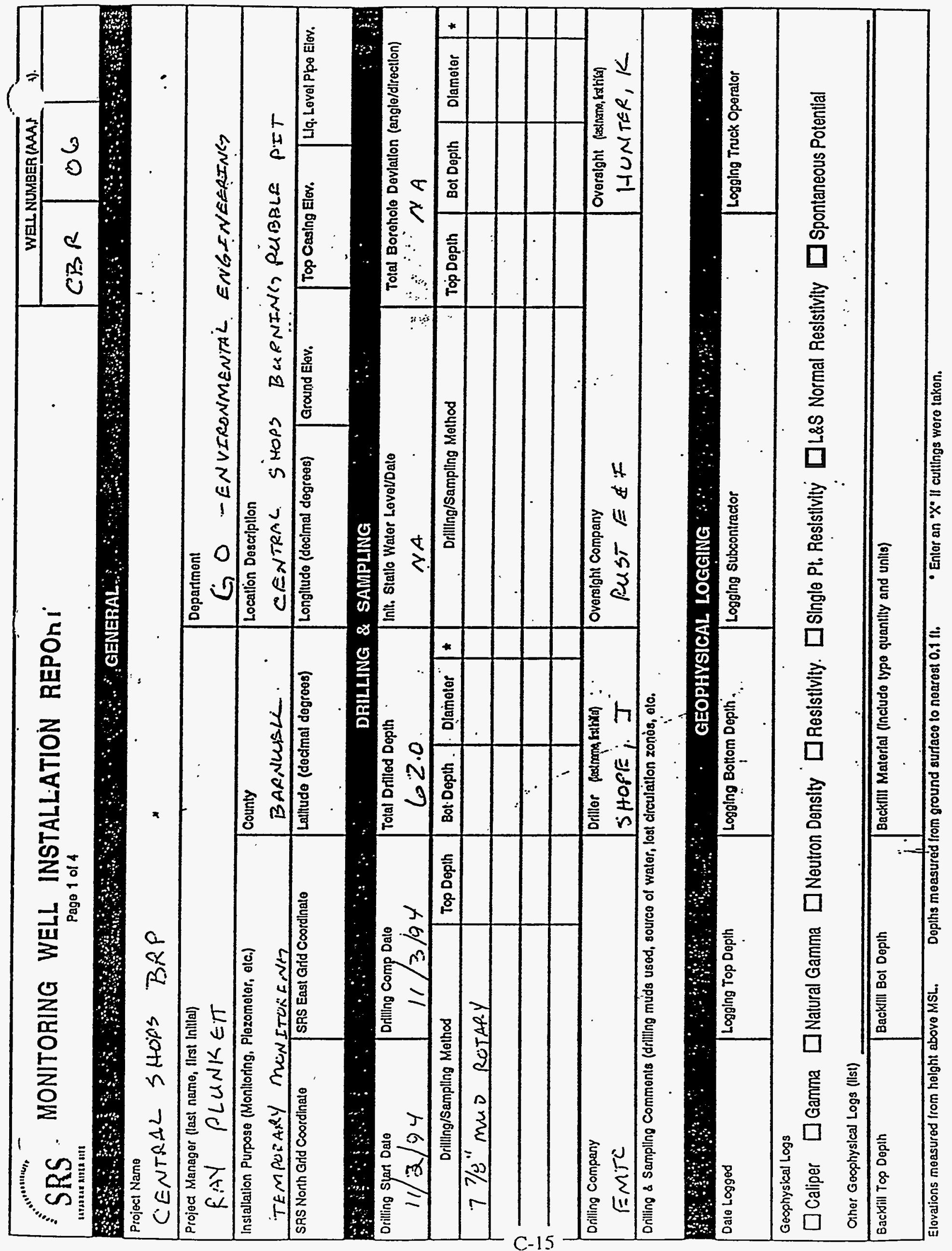




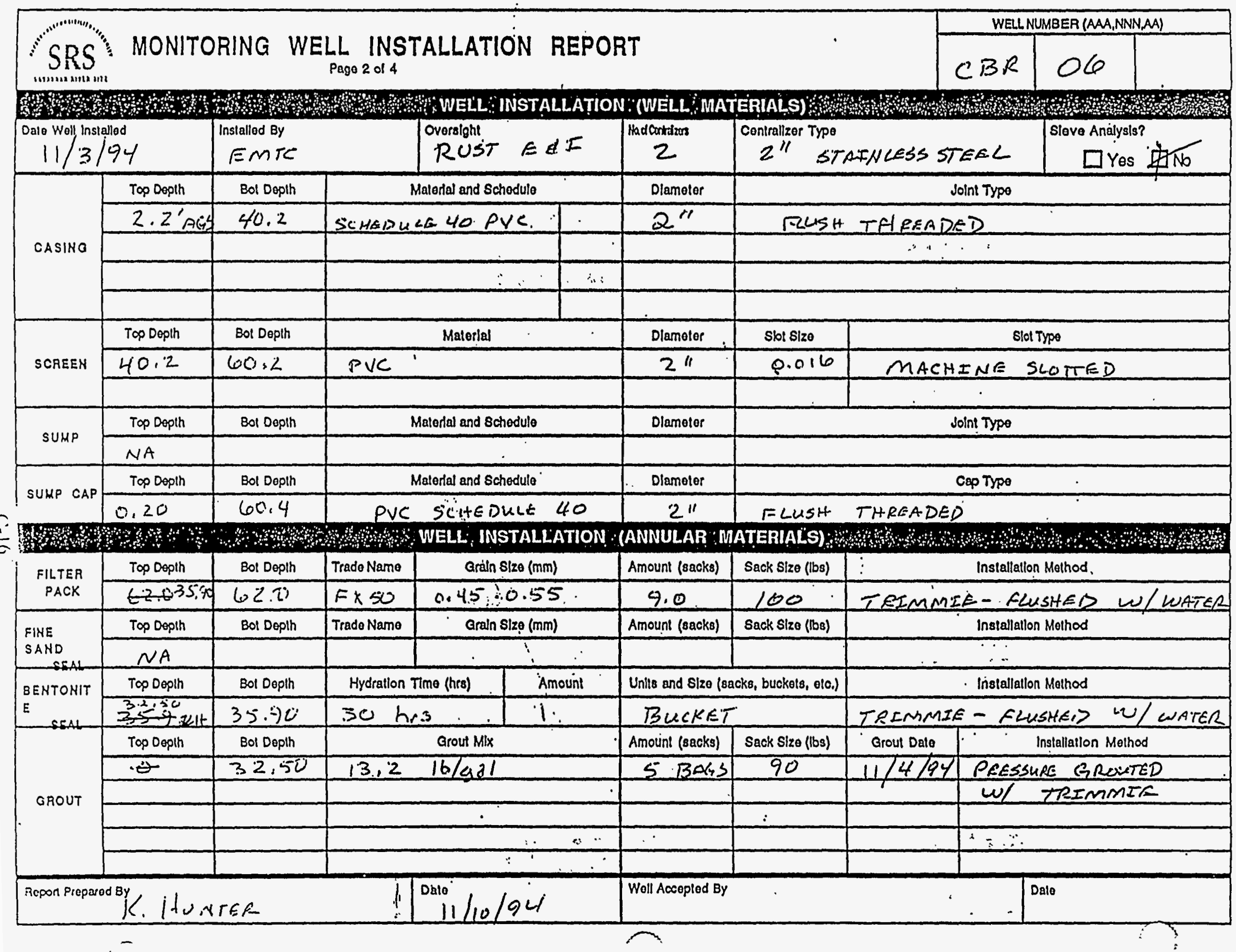


DRILLING SUBCONTRACTOR EMTC

('ER Jchn Sibope

DATE OF WELL INSTALLATION .11/3/94 TECH. O.S.JCO.NAME K. ItWUTER

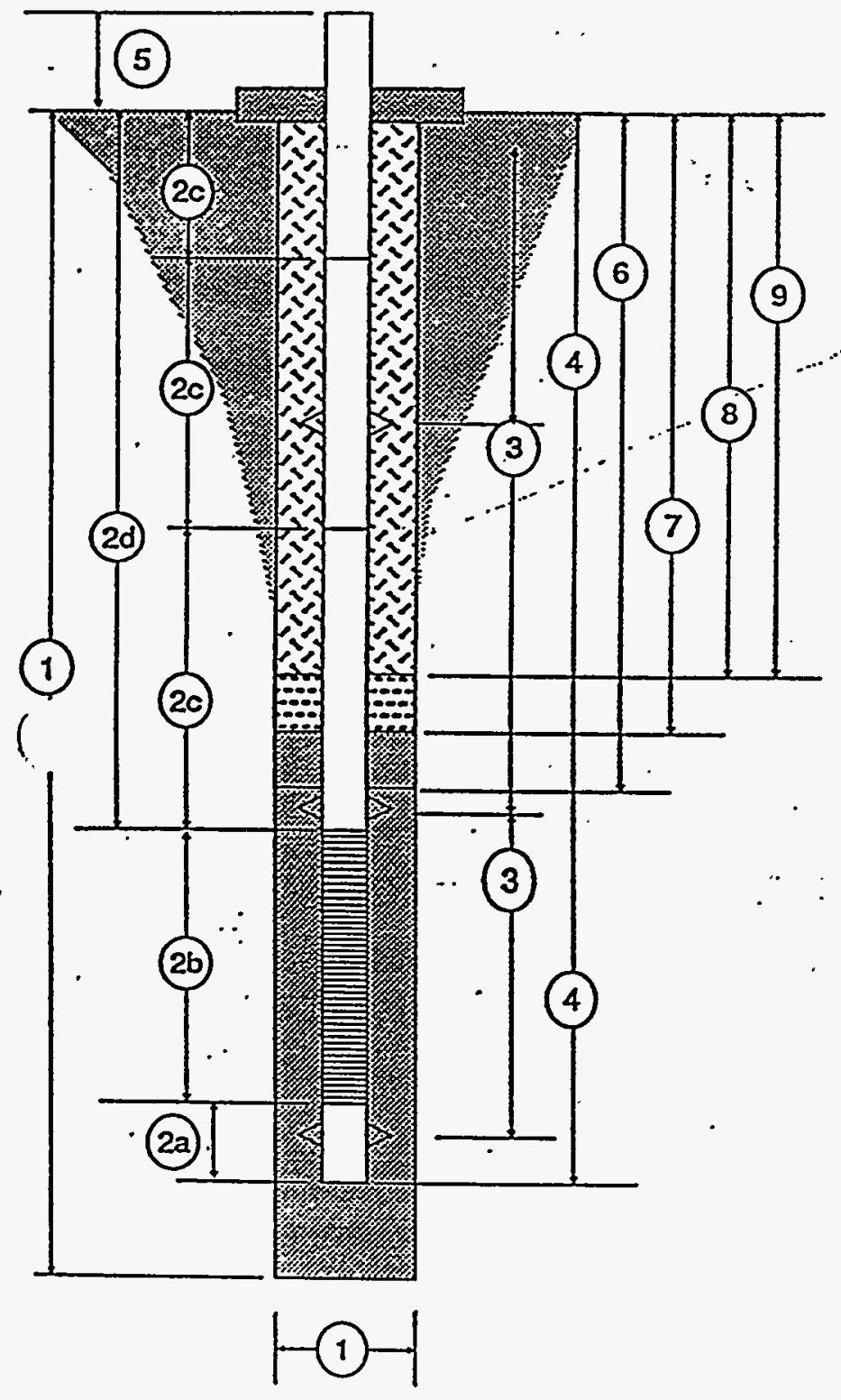

WEU NUMBER CBR-06.

SRS COORDINATES

SANITARY SEAL ELEVATION

NOTE: ALL MEASUREMENTS

ARE FROM GROUND

SURFACE AT START

OF BORING - MEASUREMENTS

TO NEAREST 0.1 FOOT.

1) Total Drilled Depth/Hole Diameter
2) Casing/Screen Tally (Measured to Nearest 0.01 Foot)

(a) Sump \& Plug Length 0,20

(b) Screen Length .20

(c) Casing Joint Lengths (Measured in Uphole Sequence From Top of Screen)

$9.96,10.00,9.96,9.95,2.51$

(d) Depth to Top of Screen 40.2

3) Depths to Centralizers $14-15$ \& $28-29$

4) Total Depth of Installed Well 60.40

5) Casing Stick Up (Standard 2.5 A.G.S.) 2.2

6) Depth to Top of Filter Pack 35.90

7) Depth to Top of Fine Sand Seal NA

8) Depth to Top of Bentonite Seal 32.50

9) Thidkness of Grout 32.50 
SOUTH CAROLINA DEPARTMENT OF HEALTH AND ENVIRONMENTAL CONTROL

around Wetas Probetion Diviloton

2600 Bufl streat

1. LOCATDNOF WELL

couny: BARNWWLL

Syum Name: C BR-OG

Latlevon:

Conoluas:

Destance And Durection from fiald intorcections

\section{- SEE ATTACHED MAP}

Street aocrese \& Ciay of Wefl Laction Smeten Hap:

\section{"SEE ATTACHED MAP}

\begin{tabular}{|c|c|c|}
\hline $\begin{array}{cl}2 \text { CUTTING SAMPLES } & X \text { Yes } \\
\text { Geophrical Logs } & \square \text { Yes (Please Endl }\end{array}$ & osej $\bar{\square}$ & $\cdots$ \\
\hline FORMATON DESCRIPTION ." & \begin{tabular}{|c|} 
THCCNEESS \\
$\sigma$ \\
STRuThus
\end{tabular} & 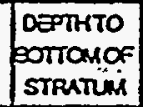 \\
\hline SANDY CLAV te CLAYEY SAND & 62 & $\cdot 62$ \\
\hline - & & \\
\hline & & \\
\hline$\therefore \quad . \quad$. & & \\
\hline - & & \\
\hline & & \\
\hline & & \\
\hline & & \\
\hline . & & \\
\hline - & & \\
\hline & & \\
\hline & & \\
\hline & & \\
\hline hodicate weler besing zomas & & \\
\hline 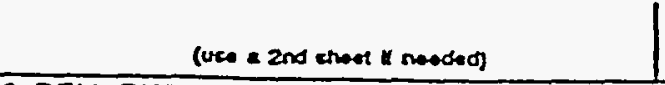 & & \\
\hline
\end{tabular}

\section{REMARKS}

Columbla,E.C. 20208

4. OWNER OF WEUL:

Aodrese

DEPARTMENT OFENERGY AIKEN. S.C. 28801

Tosponon Ne

Enomer J. L. JANSSEN

AOdrace BLOG 235-R. SRP

RLKEK, SC 2900

Telaptrone No.

$452-7648$

5. WELL DEPTH (Completed) Date staned: $11 / 2 / 94$

60.4011.

Daw Completes: $11 / 3 / 94$

6. DRU METHOD MUO ROTARY

7. USE: MOKITOR WELL

Public Suppty-Pemit No.

B. CASING THREADED

thight: Abovaldelow (tl.)

Oiam.

in.

Surtace

Type

in. io

th. depth

Woigra :

105.11t.

\section{SCREEN :}

Trpo: PVC

Slougauze 0.016

Sat Batwen 60.2 ind and 40.2

at.

Divestsnoer ves $\square$ no $X$

Sinv Anzlysis $\square$ Yos (Piezse Enclose)

Diam 2

10. STATIC WATERLEVEL

ft. below land surlace after 24 hours

\section{PUMPING LEVEL Bolow Lind Surzaco}

- It attar____ the purnoing

Yhelo

12. WATER OUALTY

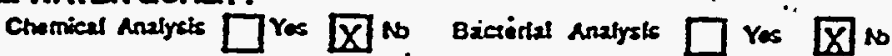
Phase Enclose Lab Resuts.

13. ARTIFICLAL FILTER Gravel Pack $X$ Yec $\square$ No

inctalted trom 62 th to 35.90 i.

Ellective cize -45-.55men unttomity coelflciont $<1.7$

14.WEL GROUTED? X Yes $\mathrm{NO}$

NERT CEMENT. 6\% BENTONITE

Depth From 0.0 ft. to

ft.

15. NEAREST SOURCE OF POSSERLE CONTAMINATKON: ___ I1. ___ direction Woll. disinfected TYes Typ upon corrpletion (X) ib Amount

16. PUMP 0ate instaltod.

HAr. namo .Modal no.

HP. vors Longth of drop pipe not instatiod

Capecty Dom Purrp Typo

17. WATER WEUL CONTRACTOR'S CERTIFICATION: This woll was orlled undor my direction and this report is true to the best of my knowledgo and beltel. REgistered ENATC nOORESS Busuress NANE

CERT.NO 


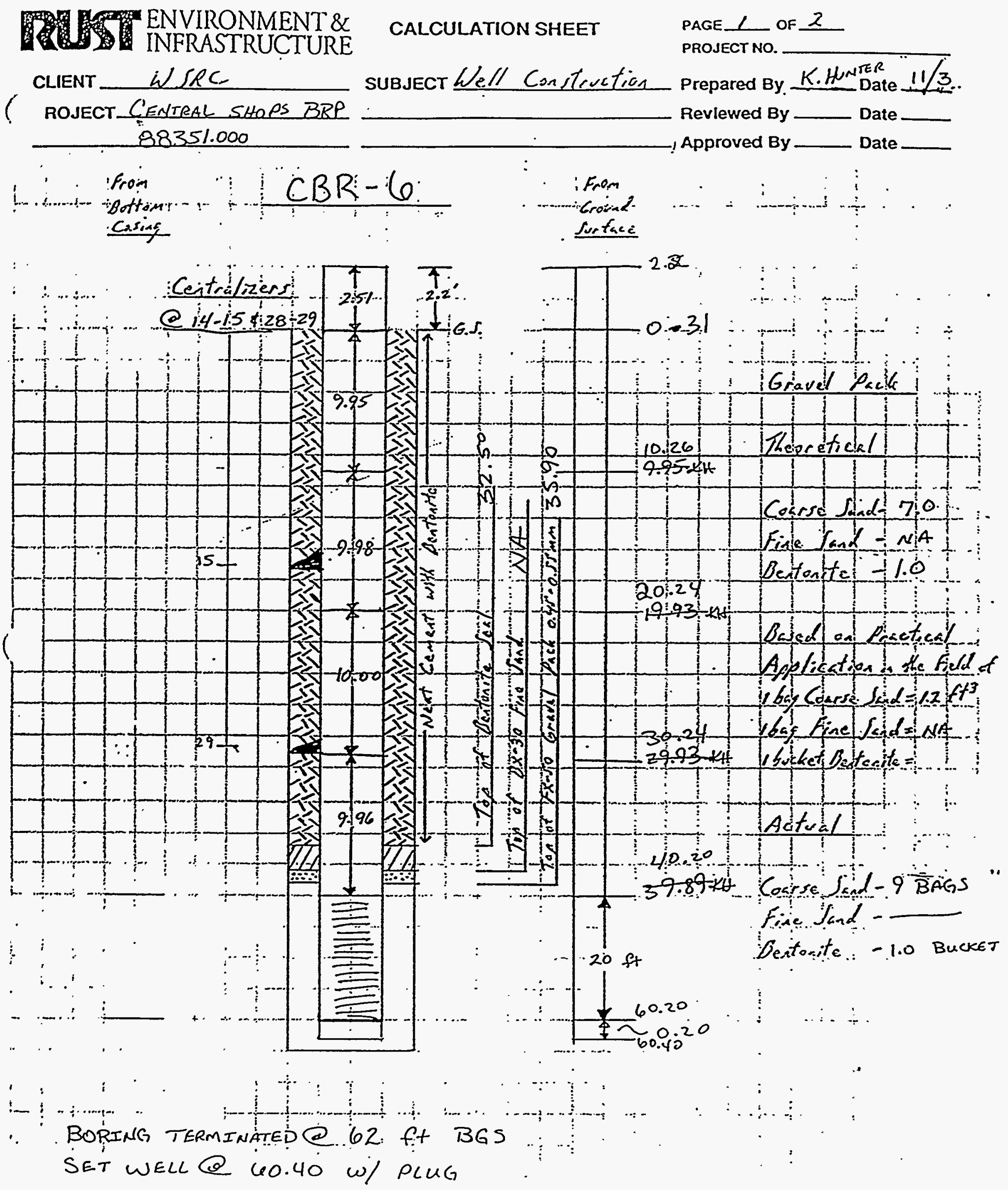

C- 19 


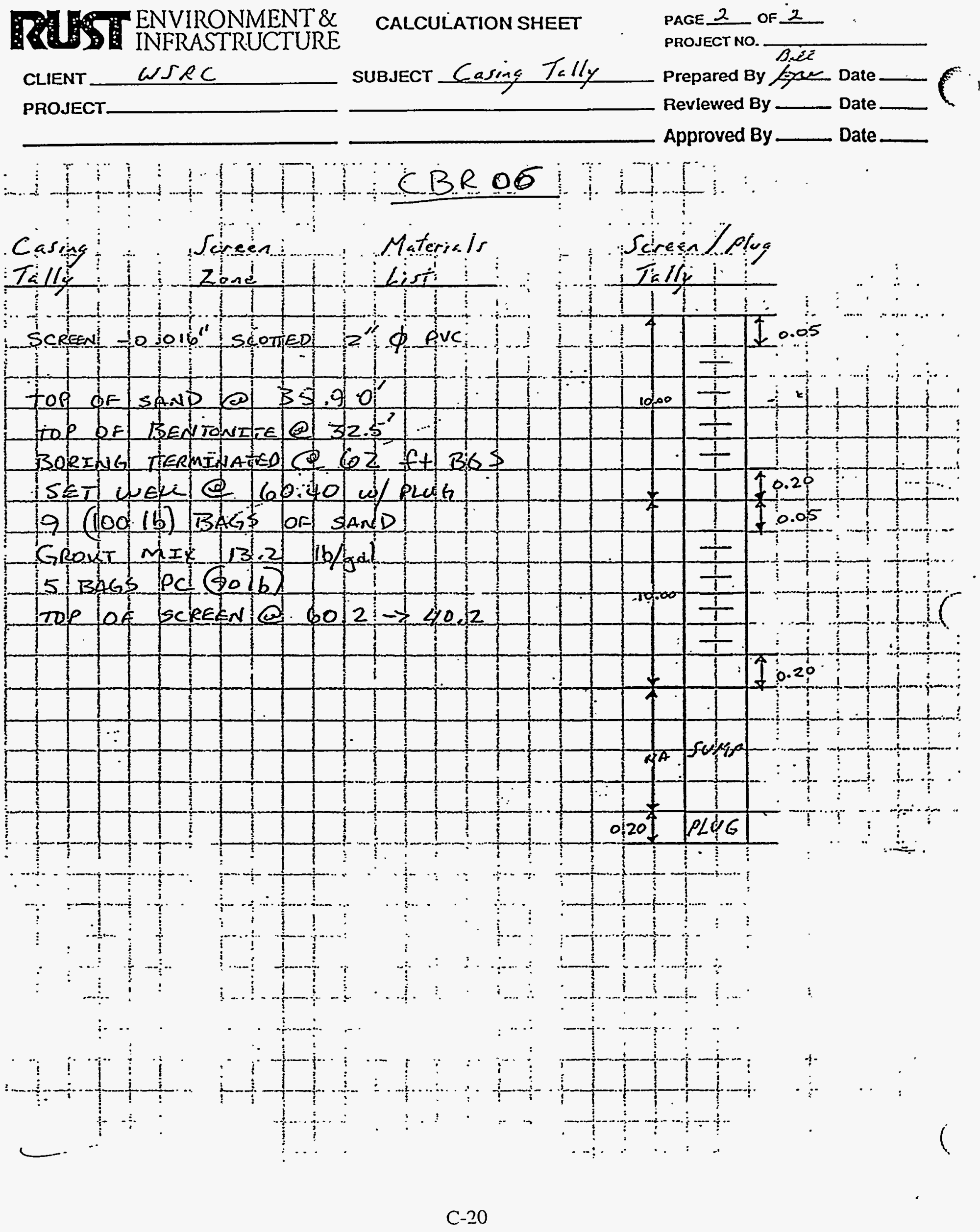


TH ENVIRONMENT\&

INFRASTRUCTURE

CLIENT

PROJECT
CALCULATION SHEET

SUBJECT

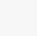

$C B R-06$

PAGE

OF

Prepared By

Reviewed By

Date

Approved By

Date

Theoretical:

CoARSE" SAND

BOREHOLE DIAMETER - 7.875 BOREHOLE DEPTH - .62 .0 SET WELL @-60.40 ToP OF SAND @ - 35.90

TOP OF SAND @ - 35.90
ONE BAG. Of SAND $=1.2 \mathrm{ft}^{3}$

$$
\begin{aligned}
& V=\pi r^{2} h \\
& V=\pi\left(\frac{3.94}{12}\right)^{2}(26.10)-\pi\left(\frac{1}{12}\right)^{2}(24.5) \\
& V=8.30 \mathrm{ft}^{3} \text { OR } 6.9 \text { BAGS OF SAND }
\end{aligned}
$$

C-2I 
Appendix D

Field Reports for Individual Boreholes

CS6G-11

CS6G-12

CS6G-13

CS6G-14

CS6G-15

CS6G-16

CS6G-17

CS6G-18

CS6G-19

CS6G-20

CS6G-21

CS6G-22 


\section{CS6G-11}




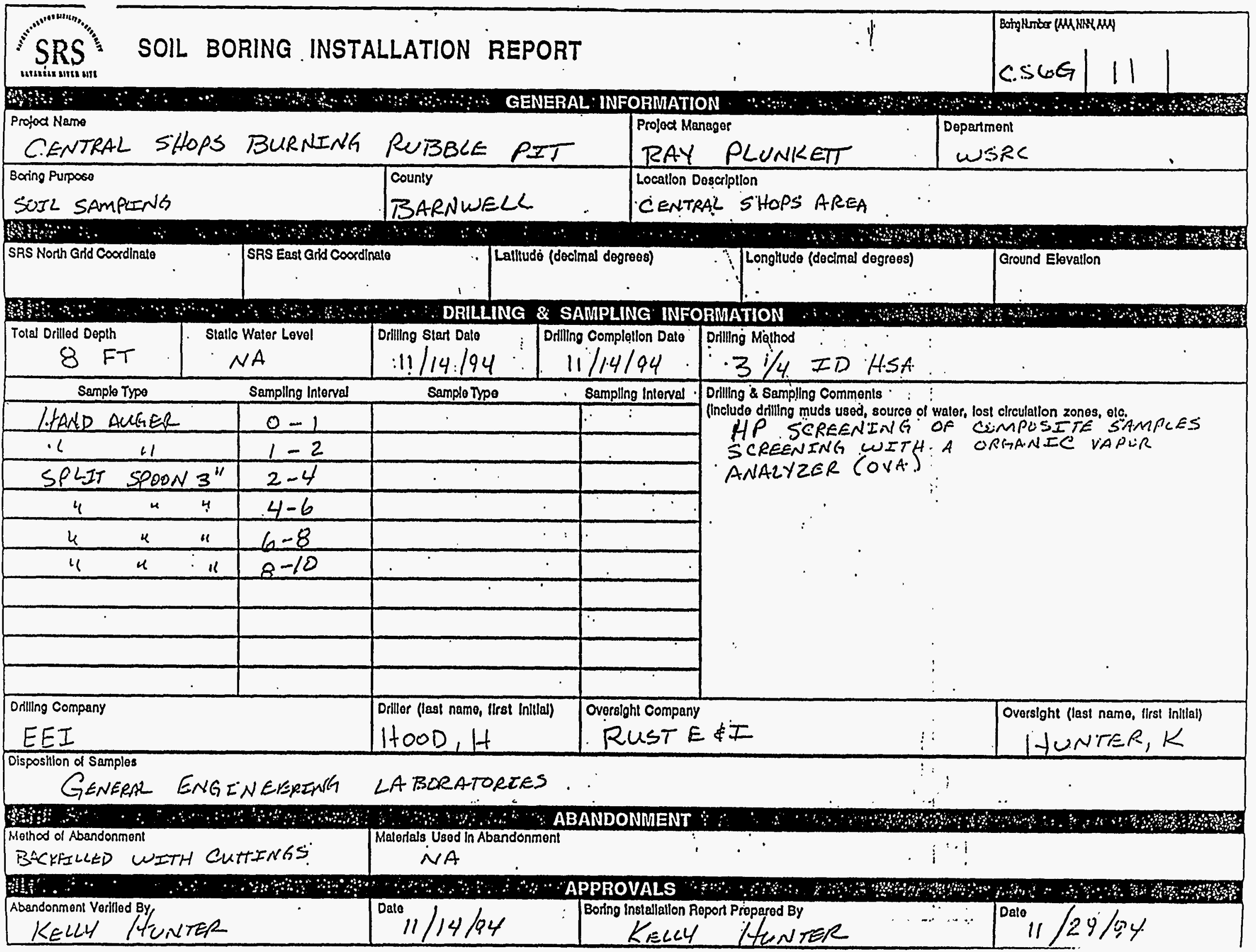


os it 30.5

FIELD GEOLOGIC LOG

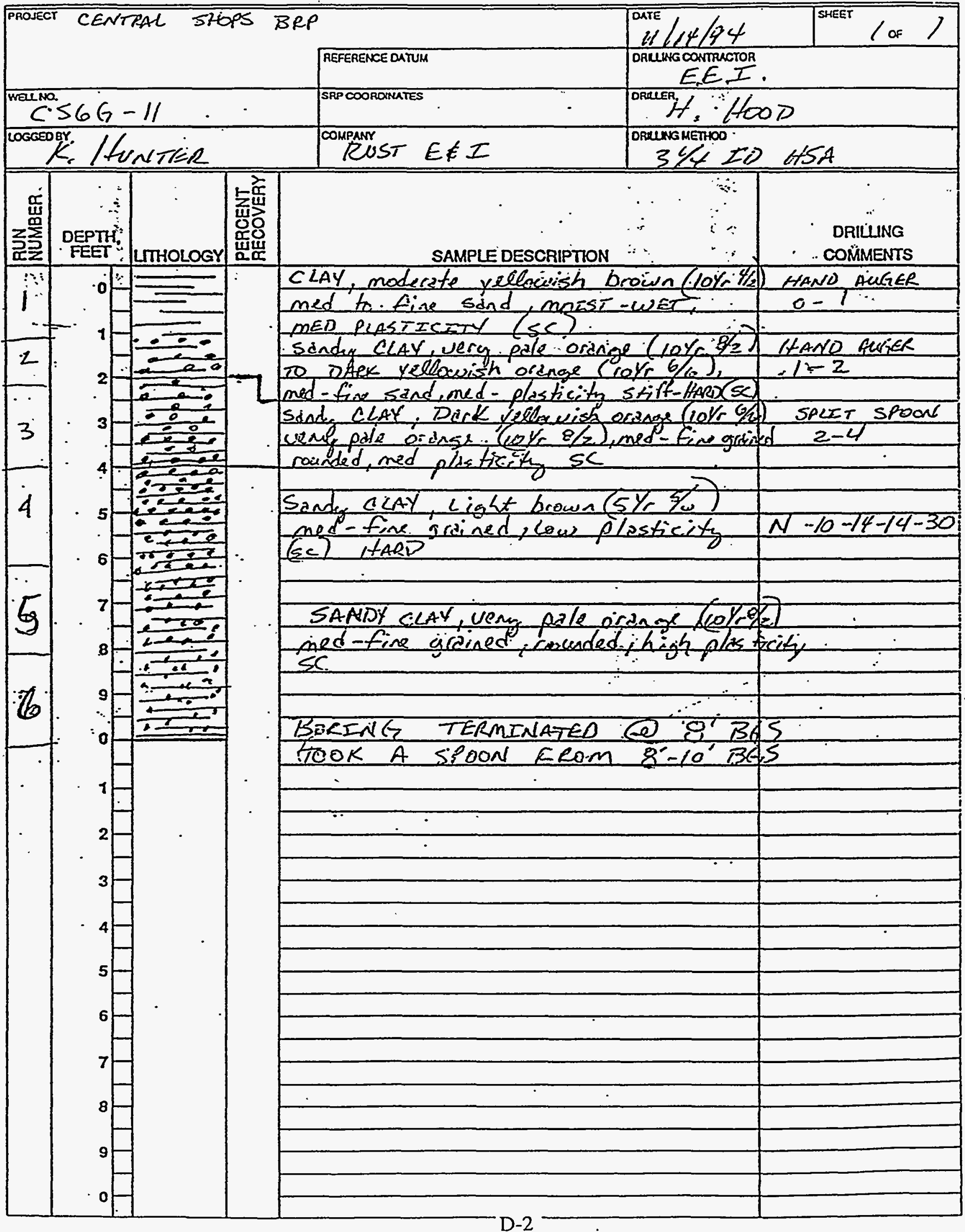




\section{CS6G-12}




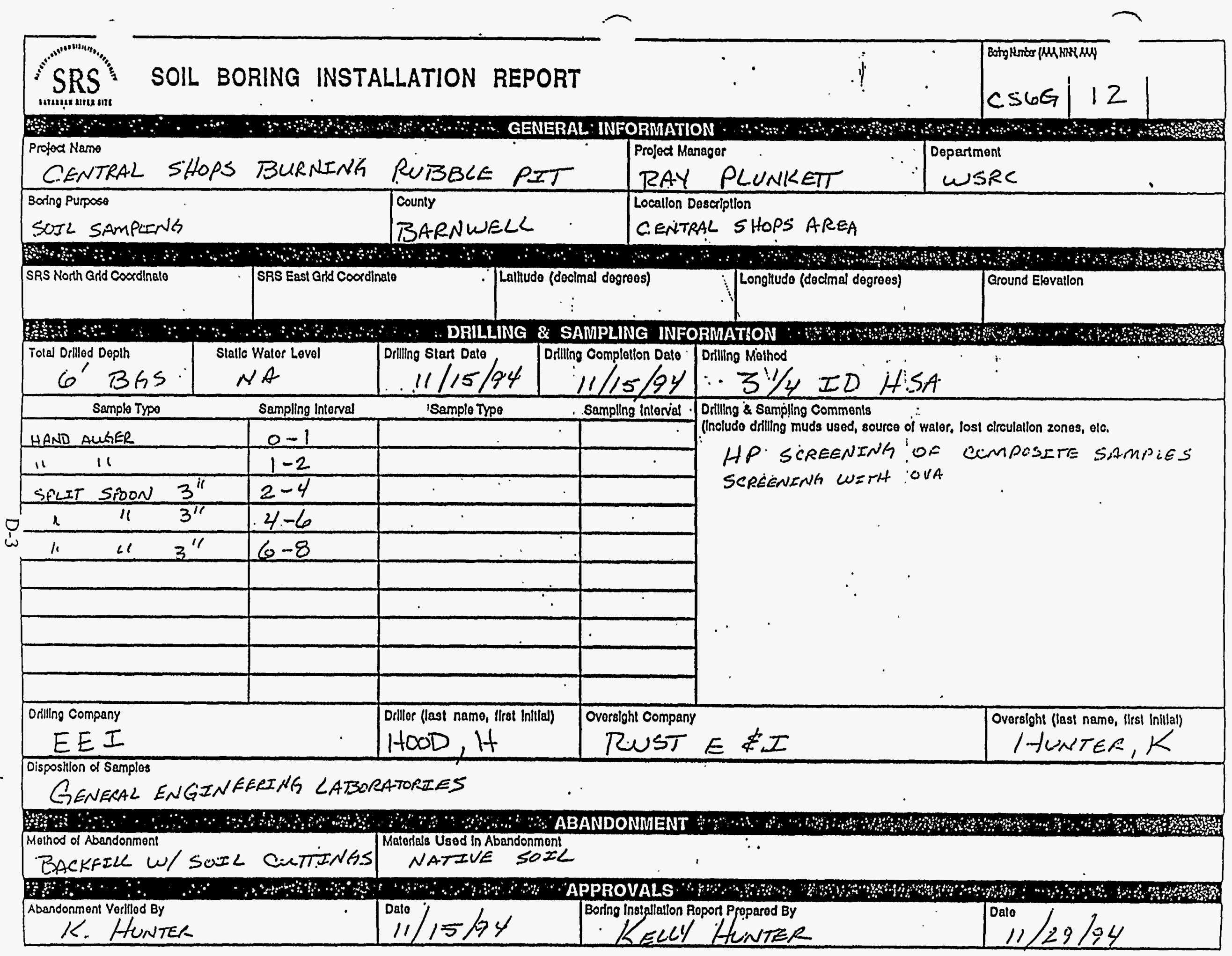


CS6G-13 


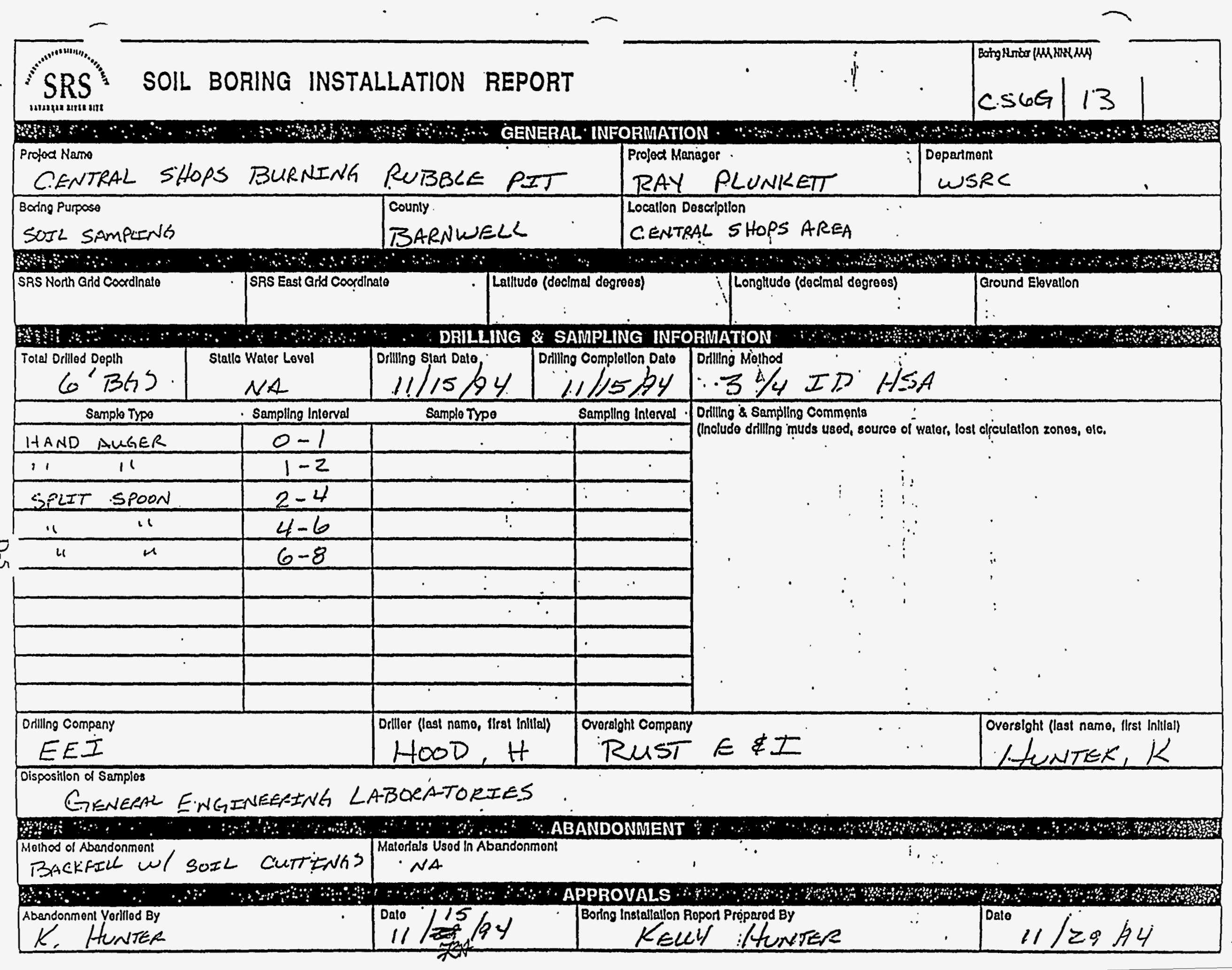


OSR 30-3

FIELD GEOLOGIC LOG

CENTRAL SHOPS BURNINGS RUBBLE PITS

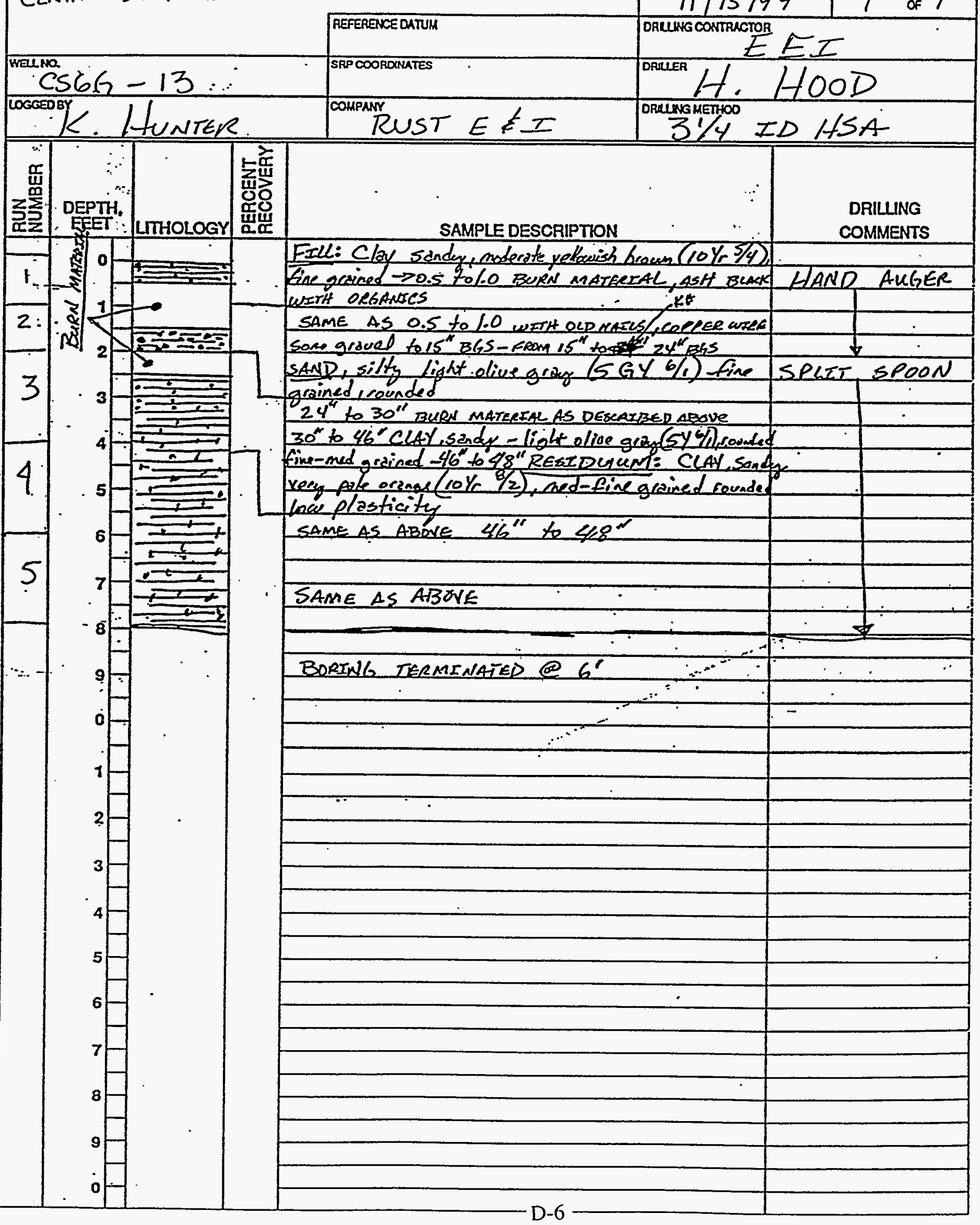


CS6G-14 


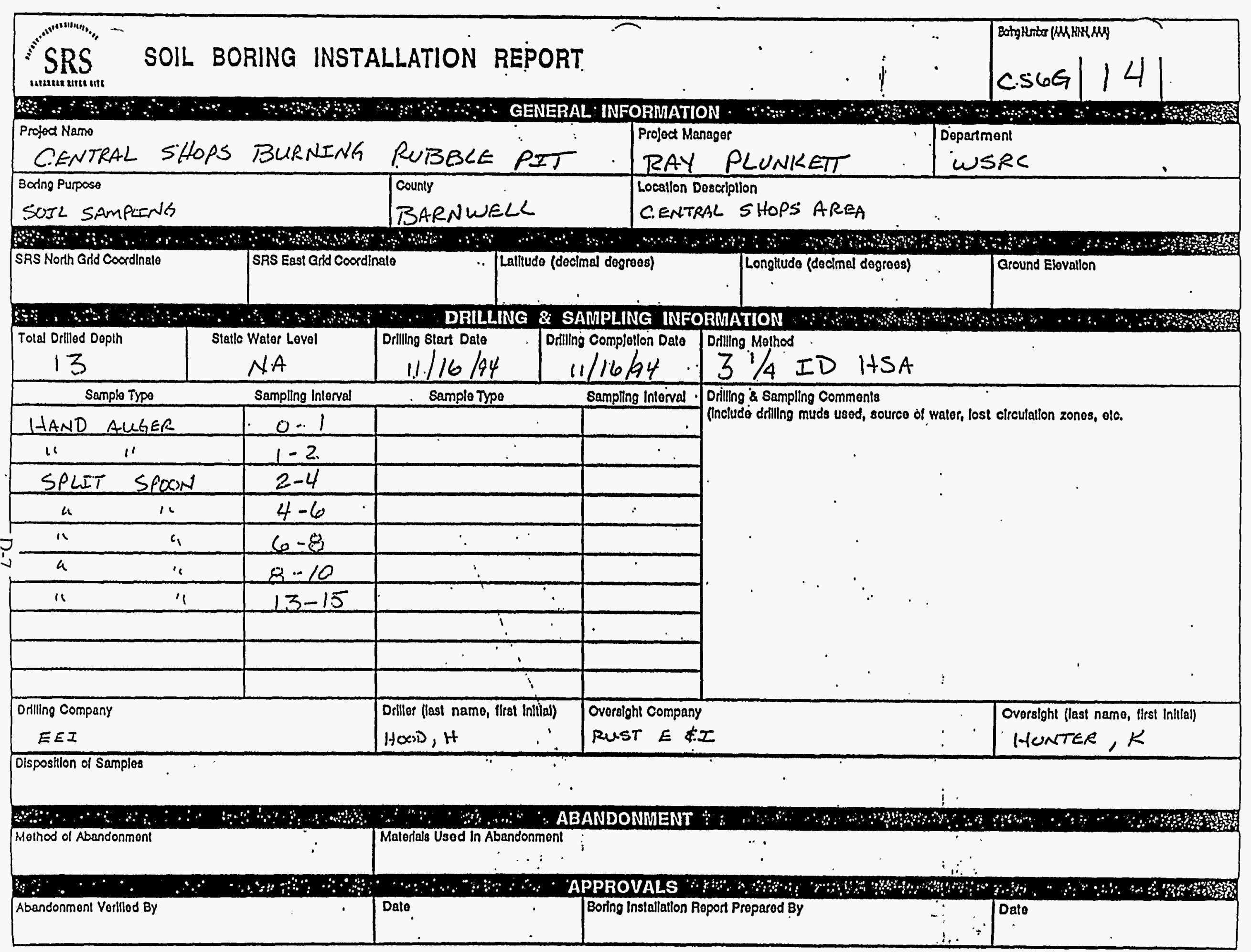


FIELD GEOLOGIC LOG

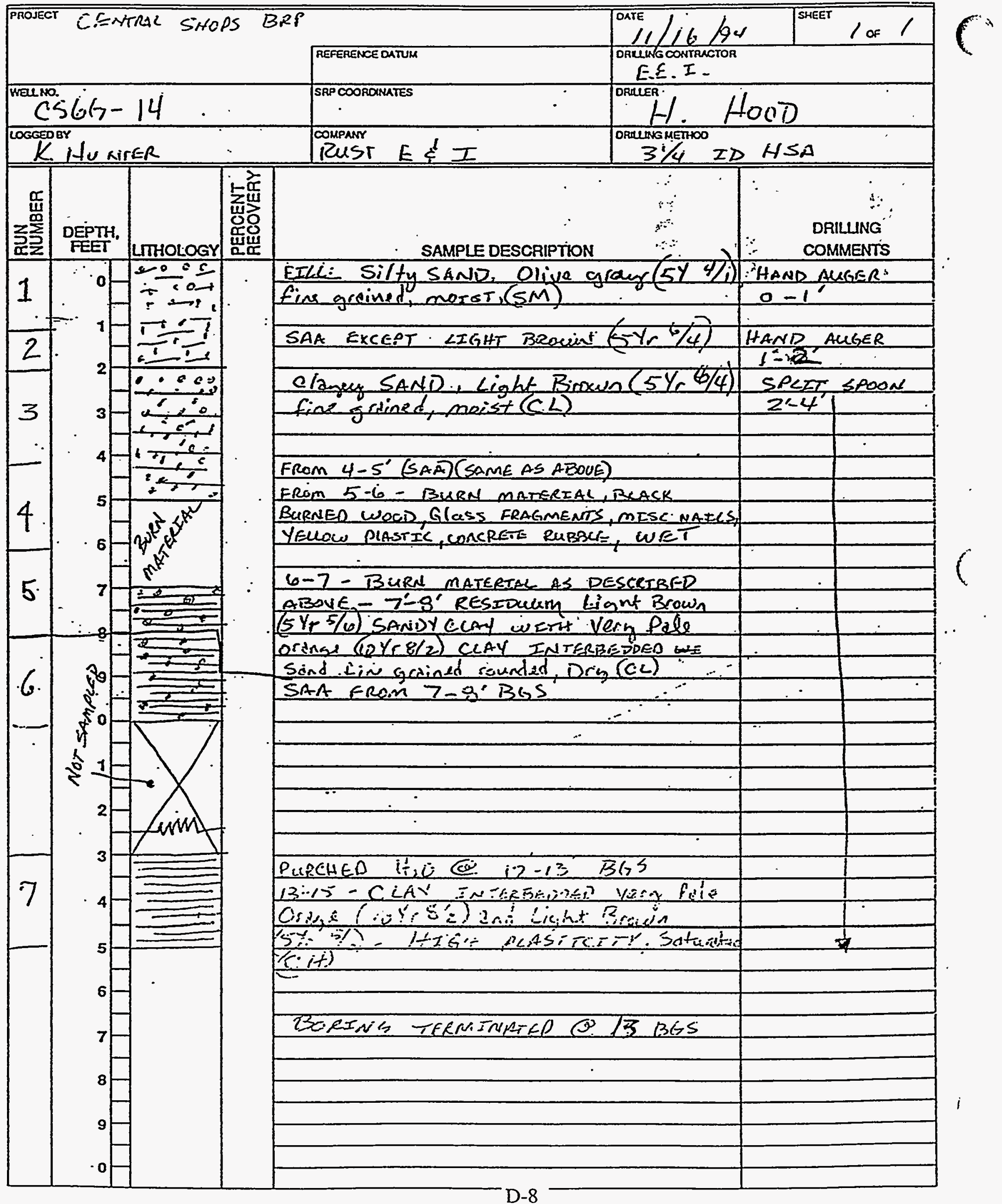


CS6G-15

1

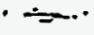




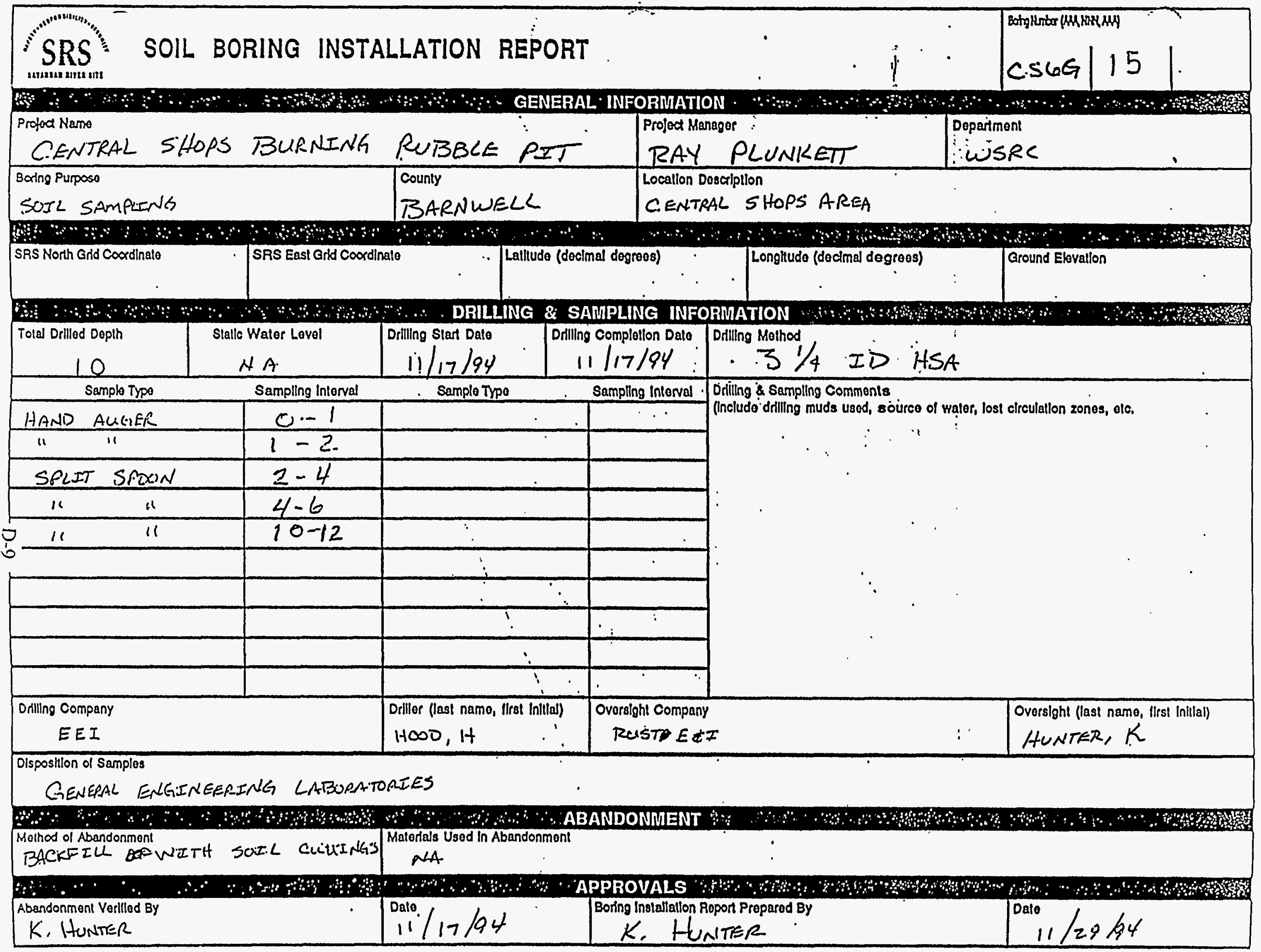


Osiर 30.5

FIELD GEOLOGIC LOG

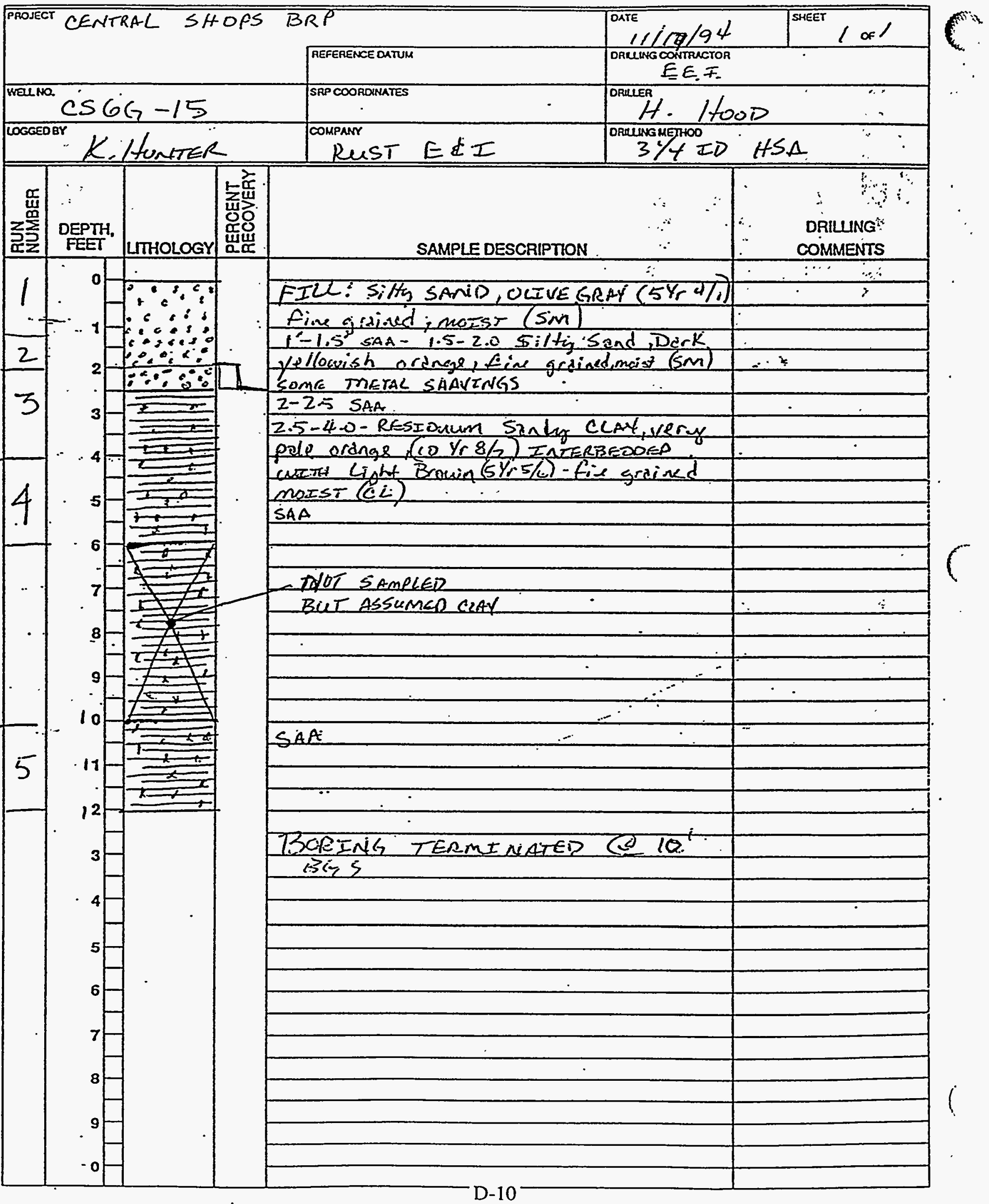


CS6G-16 


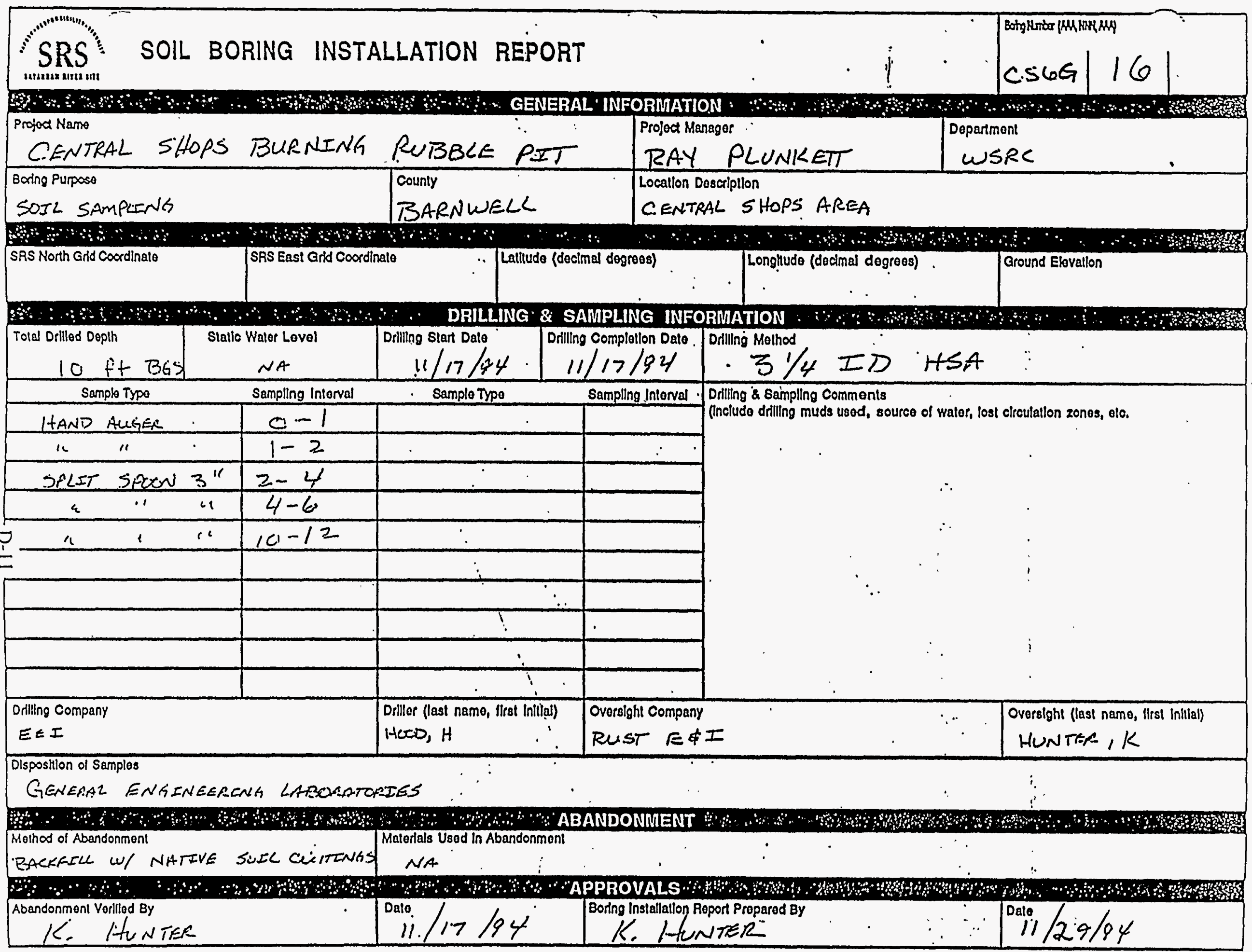


FIELD GEOLOGIC LOG

I. PENETET

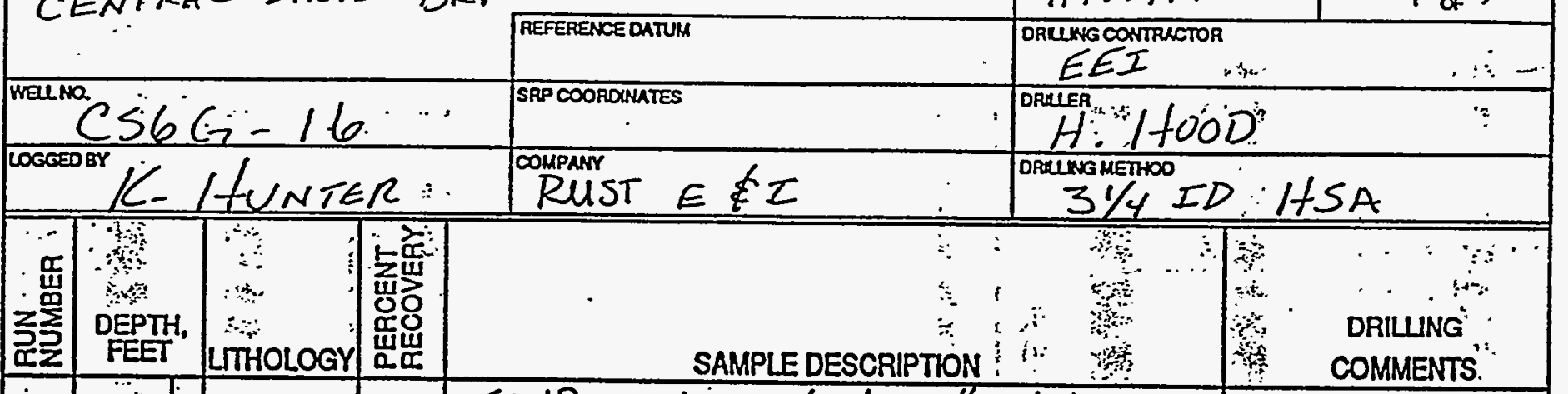

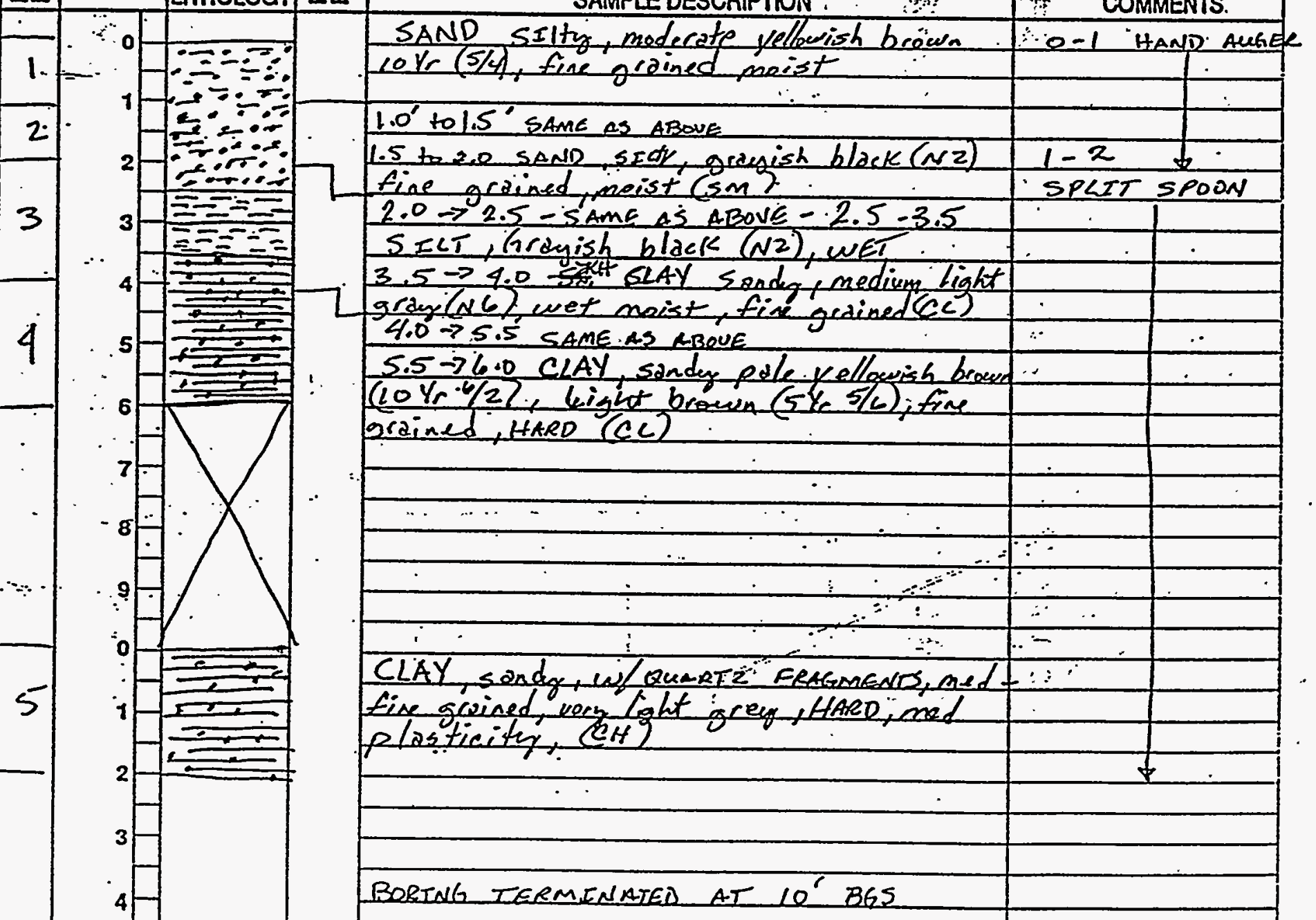


CS6G-17 


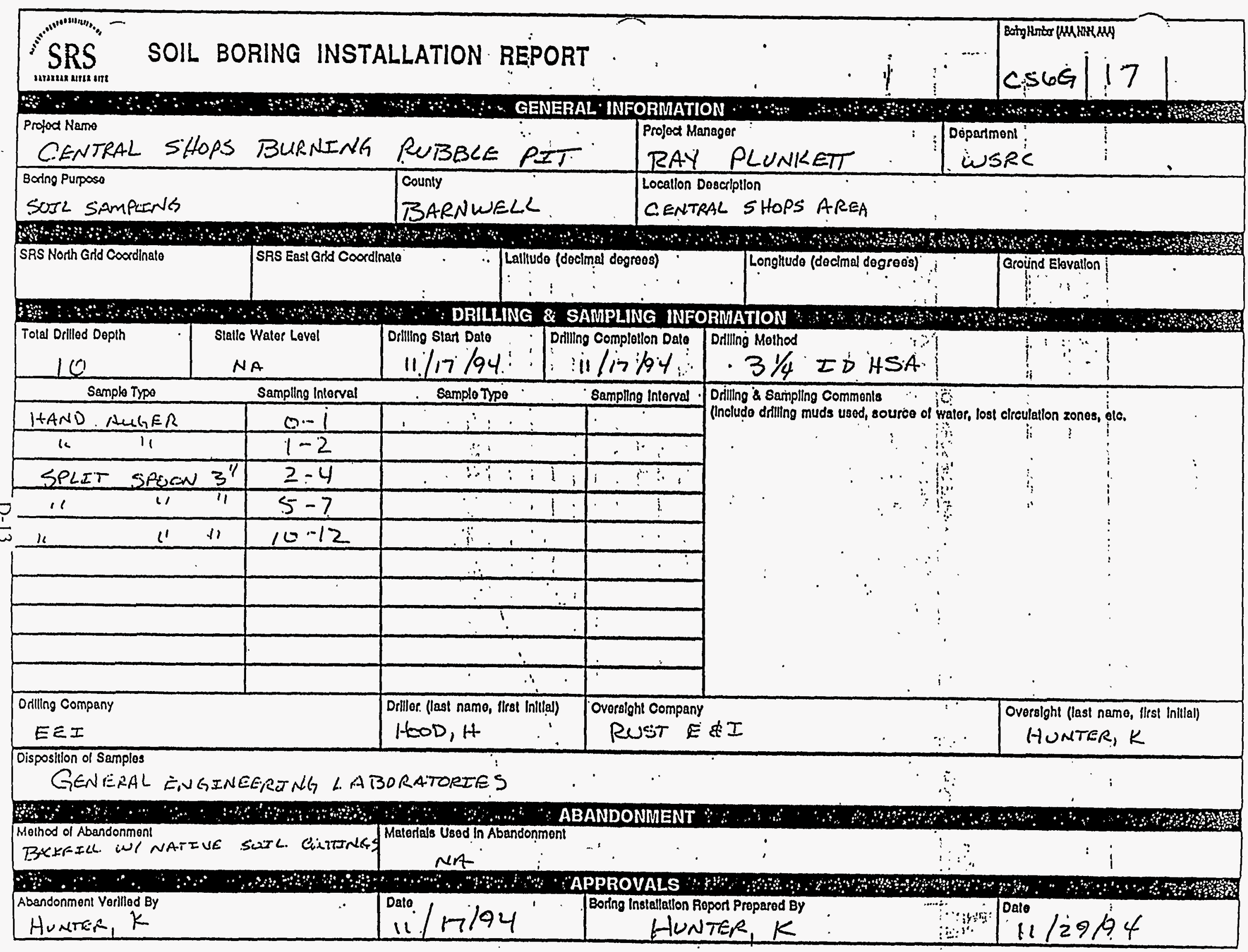


FIELD GEOLOGIC LOG

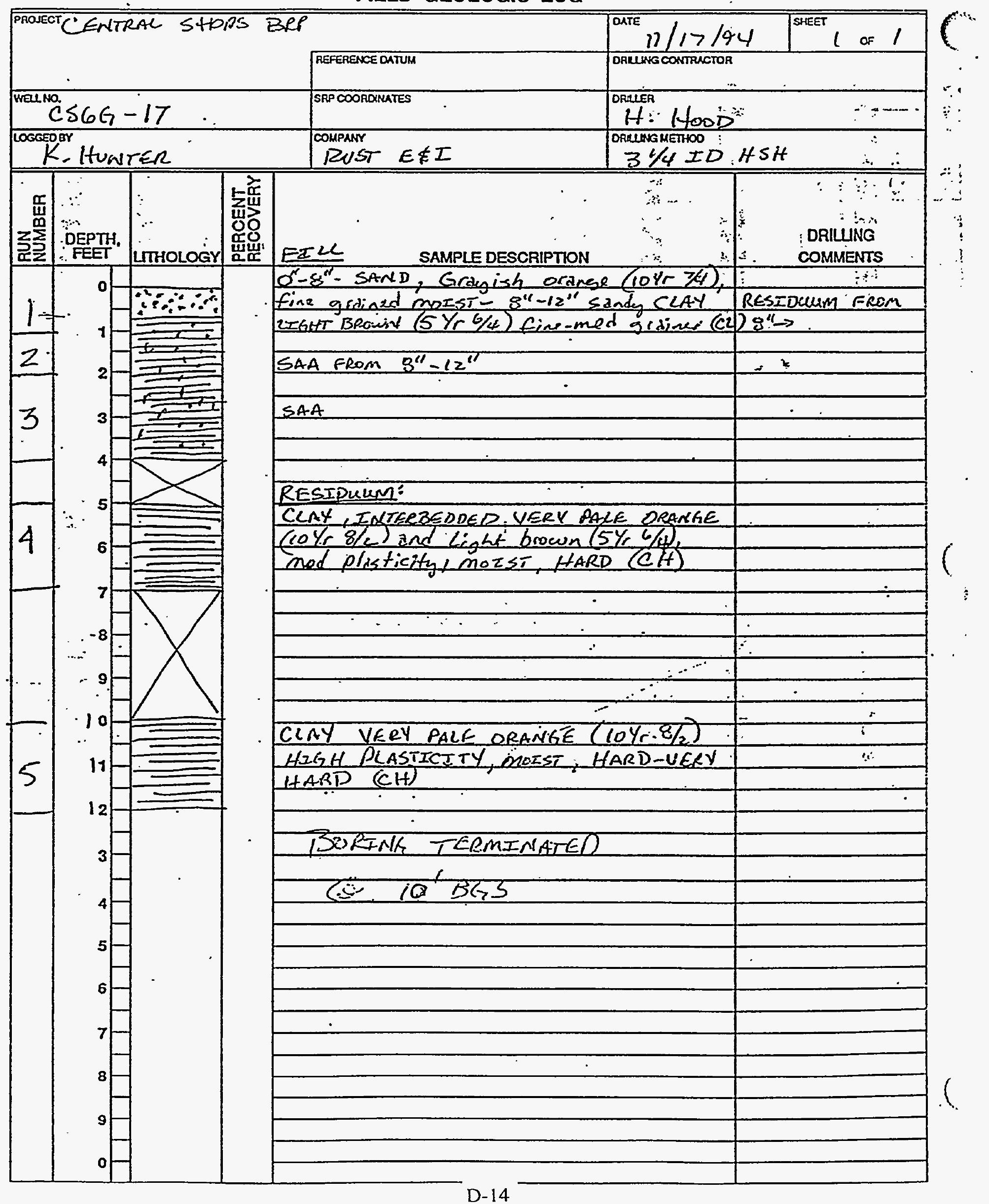




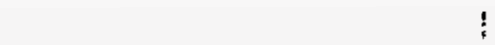

(

CS6G-18

$\because \ldots+\ldots+\cdots+\cdots$

(
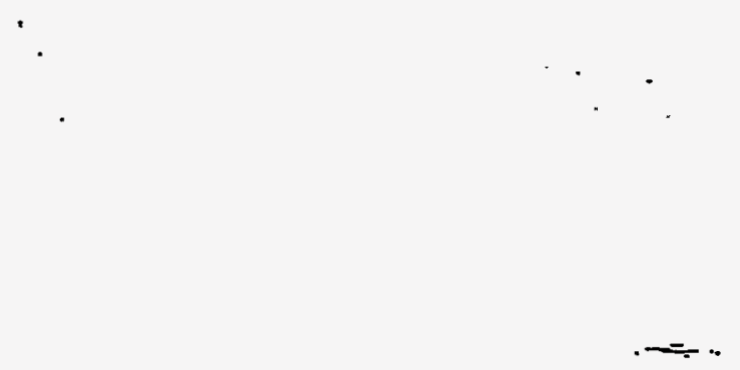

1 


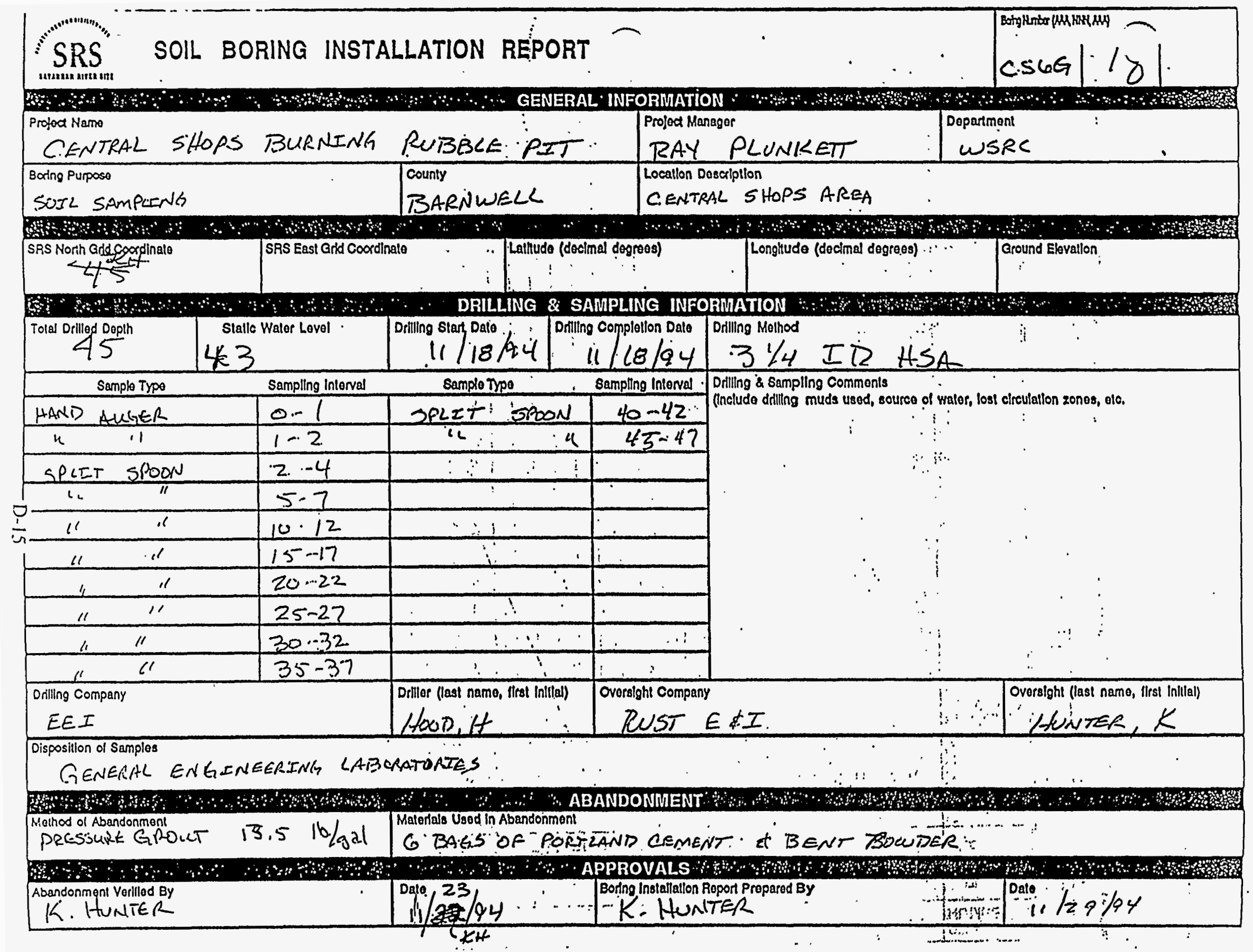


FIELD GEOLOGIC LOG

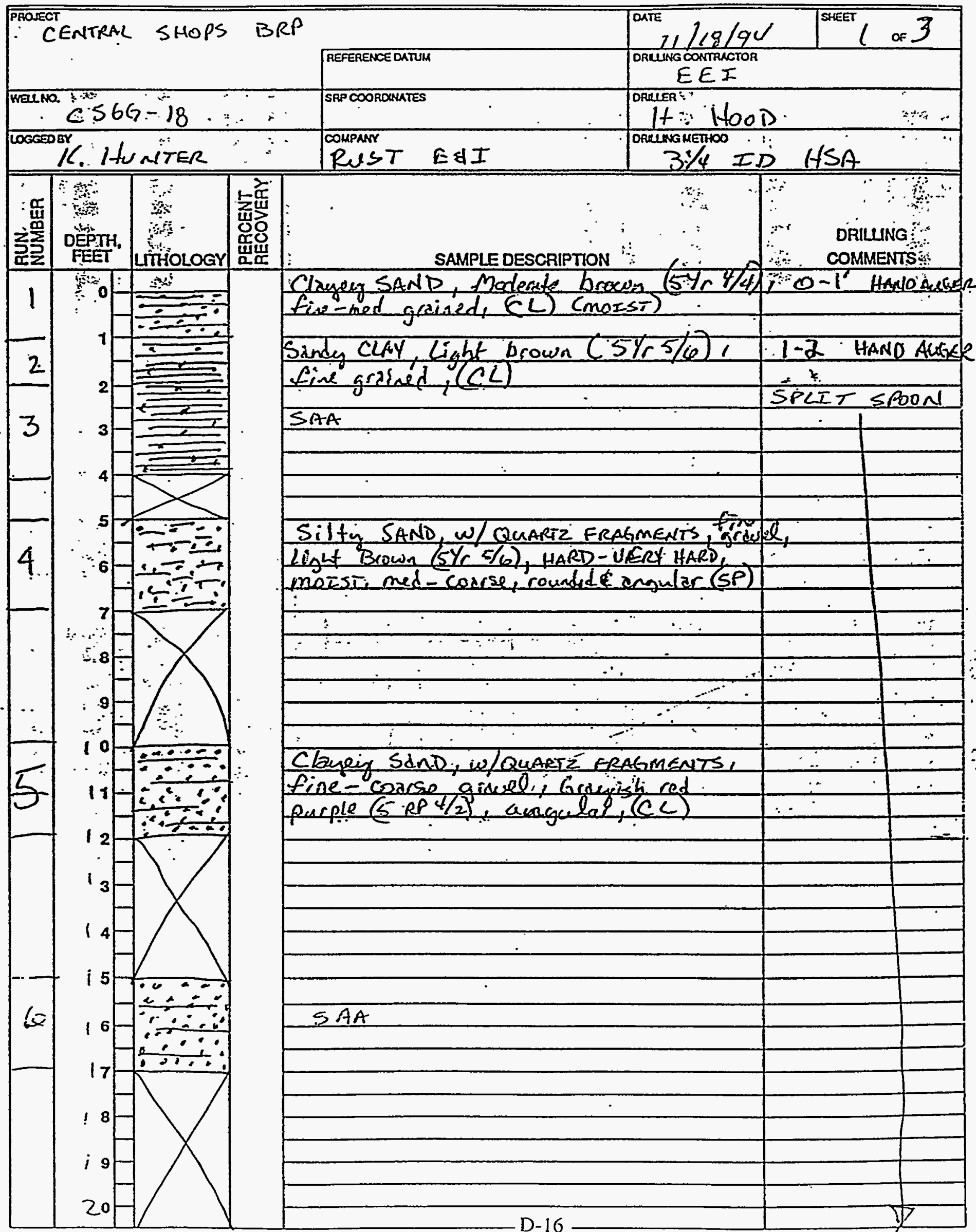


FIELD GEOLOGIC LOG

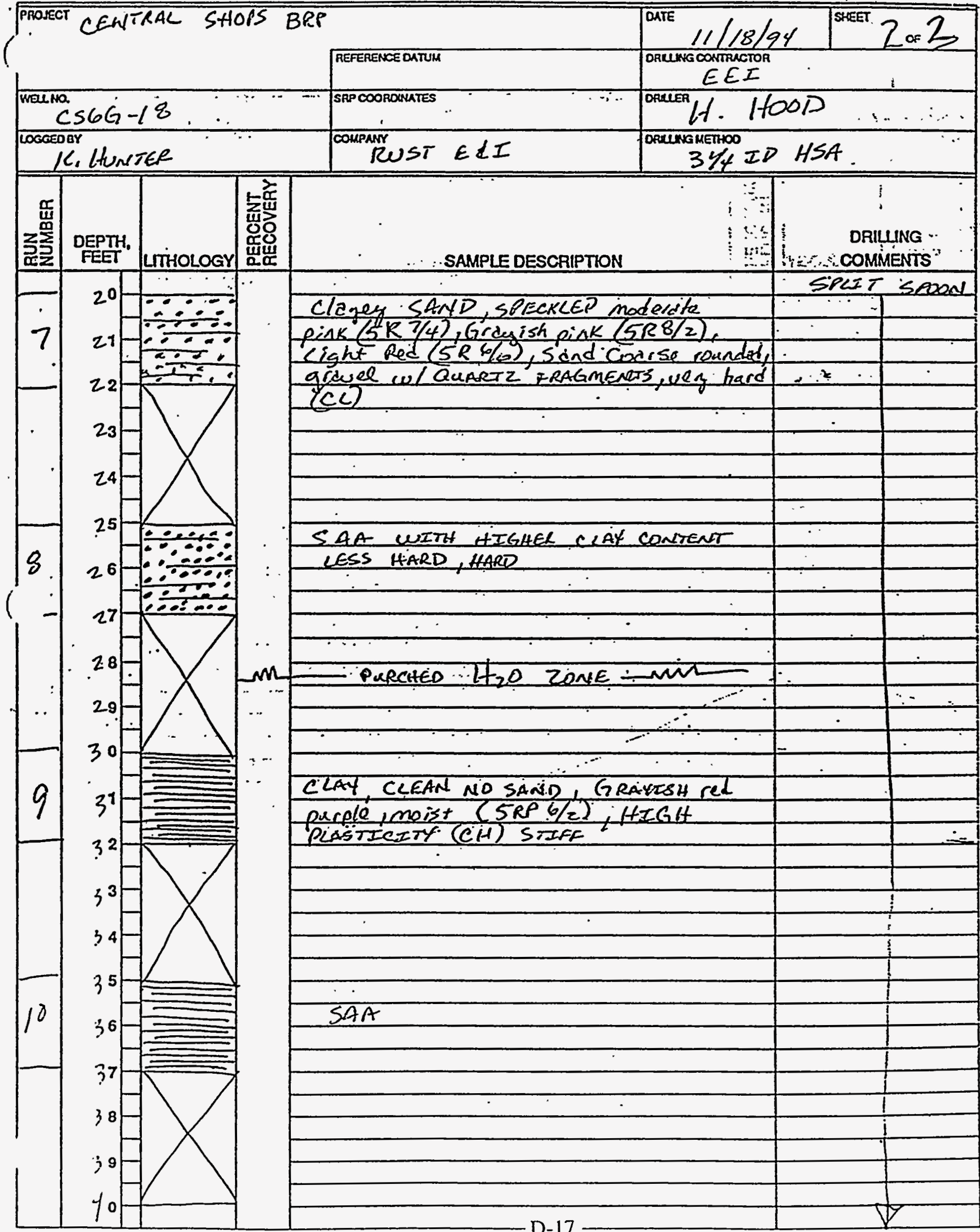


OSR 30.3

FIELD GEOLOGIC LOG

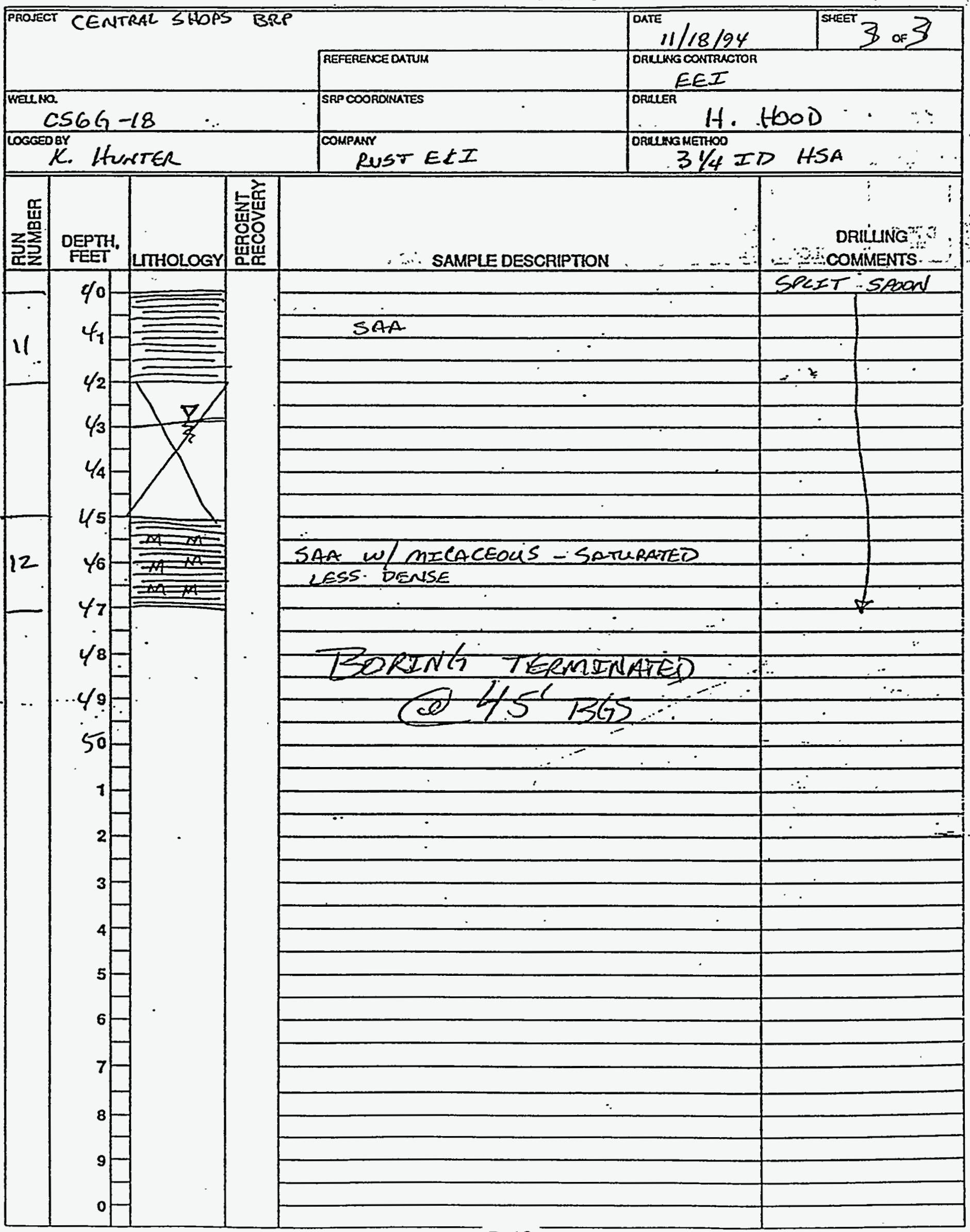


(

CS6G-19

$\therefore \quad \therefore+\ldots . \ldots$.

$\therefore \cdots+\cdot=$

$i$

.

.

$\cdot$

*

1 
FIELD GEOLOGIC LOG

\begin{tabular}{|c|c|c|c|}
\hline PRONECT CENTRAL SHOPS. BRP & & Date $11 / 22 / 9 y$ & SHEET $l$ of 3 \\
\hline & REFERENCEOATUM & 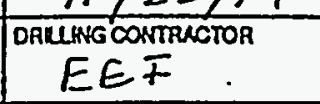 & \\
\hline CSELG $6 \%-19$ & SRPCOORONATIES & oraler $\quad \therefore 1+1+00 D$ & \\
\hline $\begin{array}{l}\text { LOGGEOQY } \\
\text { K. HUNTER }\end{array}$ & $\begin{array}{l}\text { COMPANY } \\
\text { RUST E }\end{array}$ & 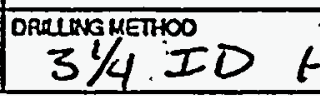 & \\
\hline
\end{tabular}

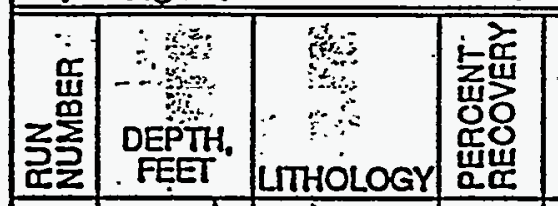

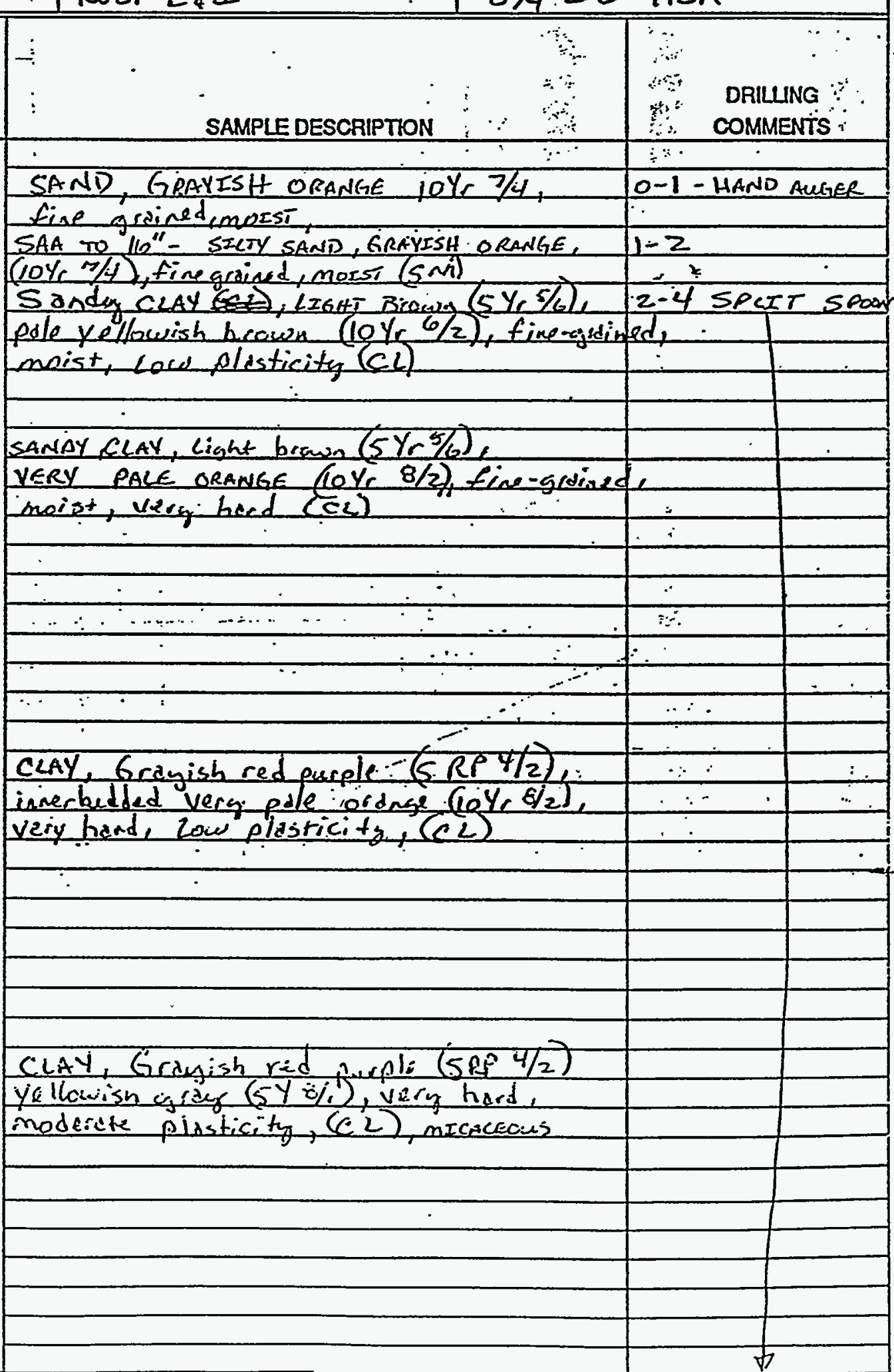


osR 30.5

FIELD GEOLOGIC LOG

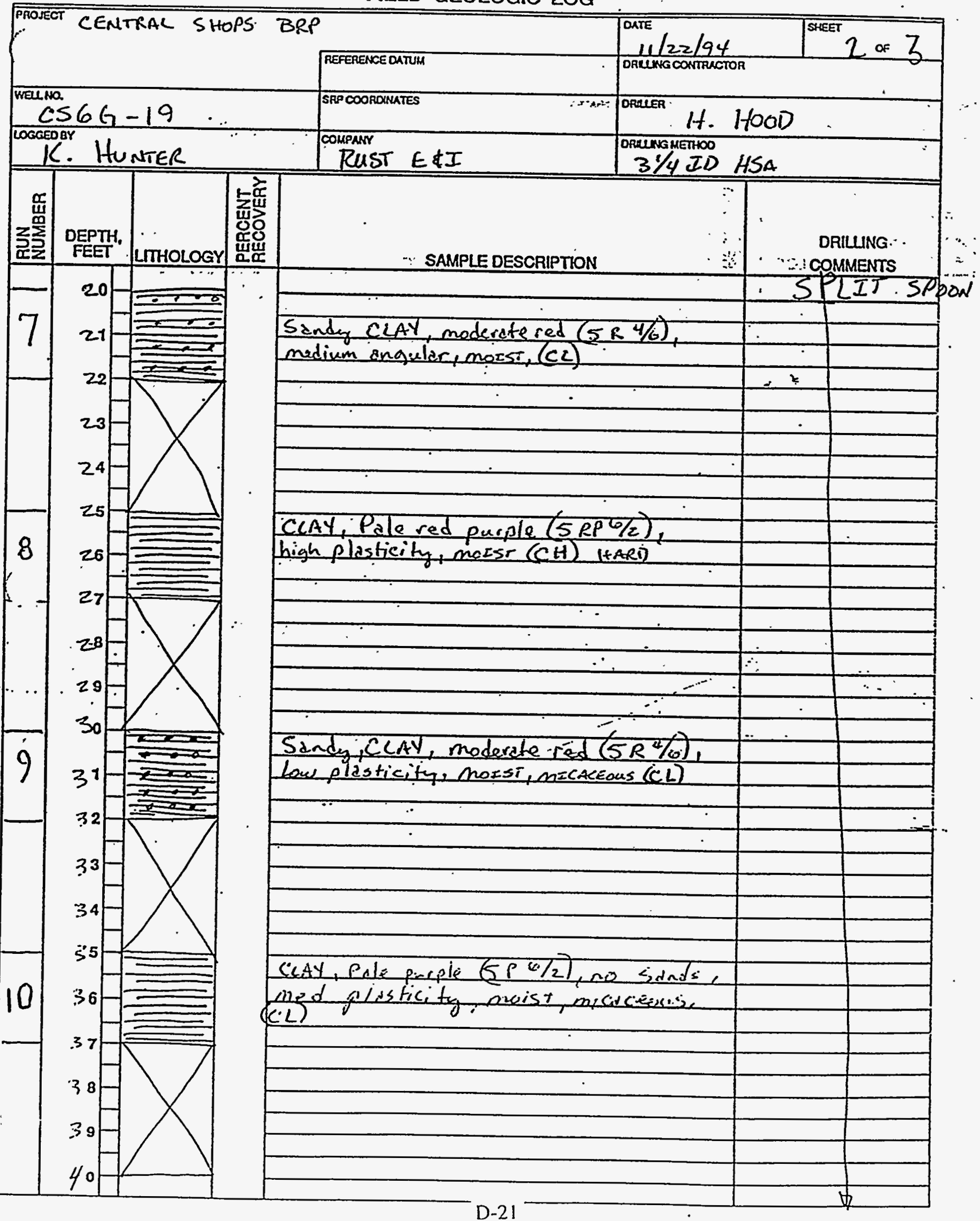


OSR 30-3

FIELD GEOLOGIC LOG

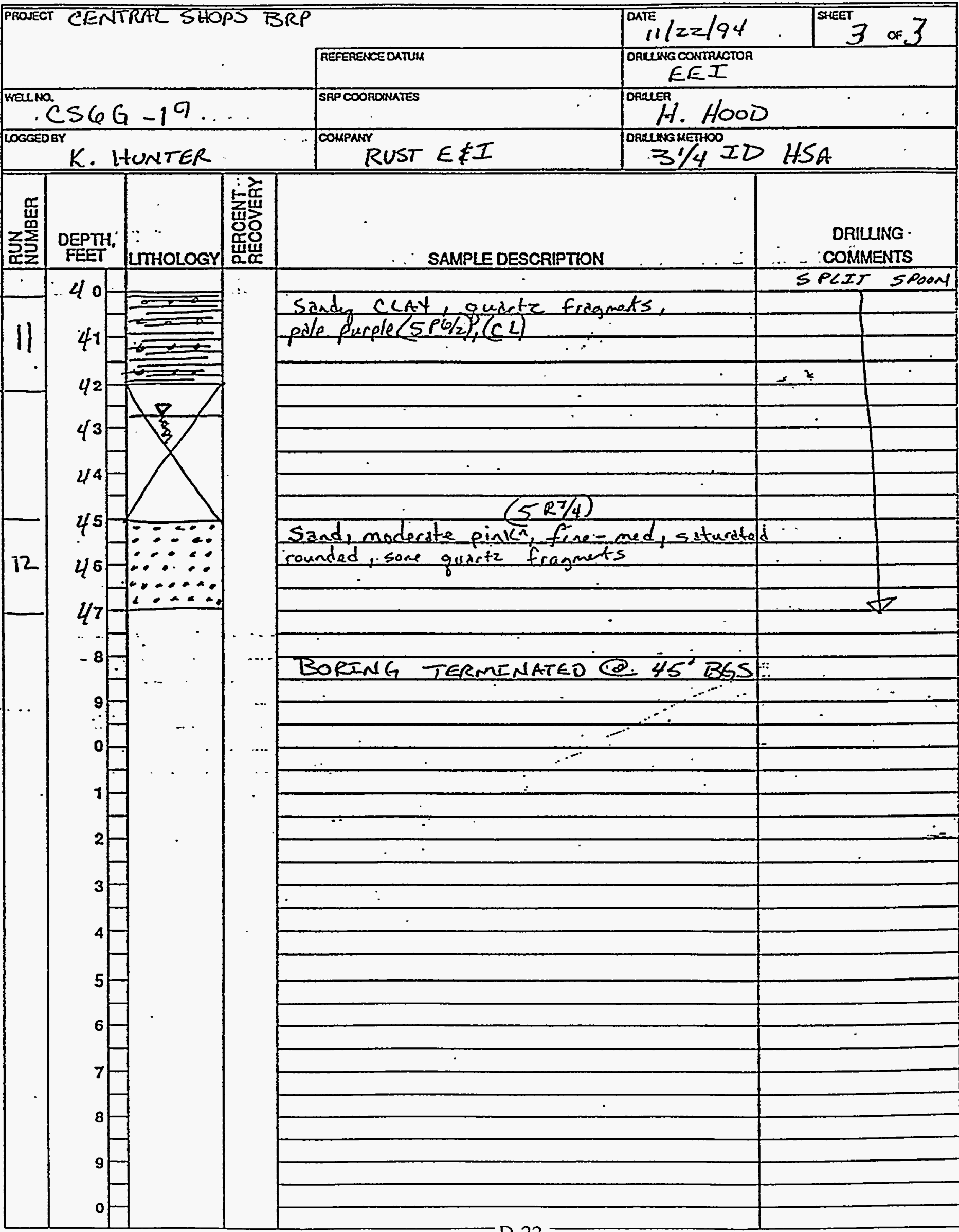


CS6G-20

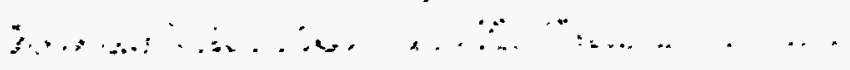




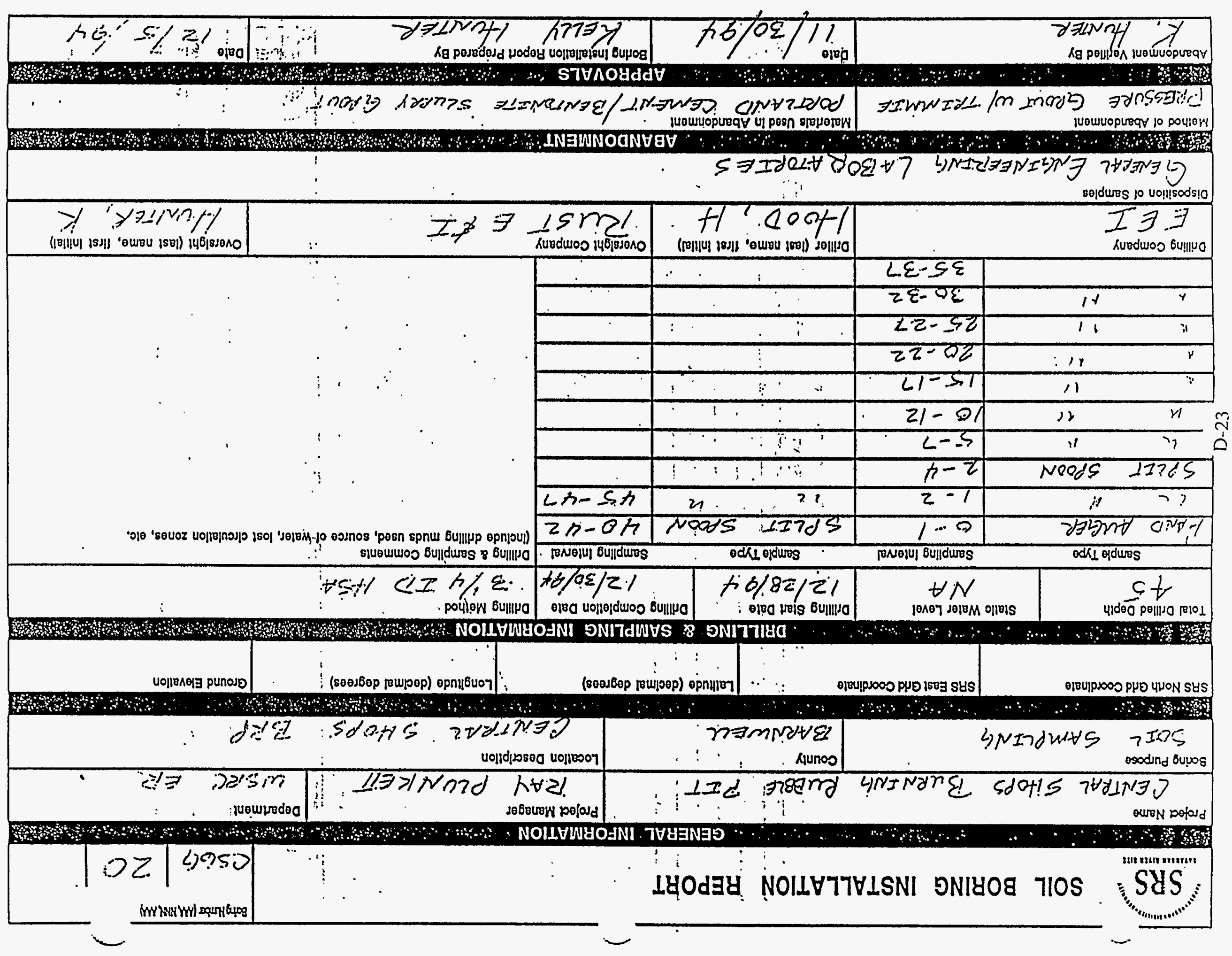


FIELD GEOLOGIC LOG

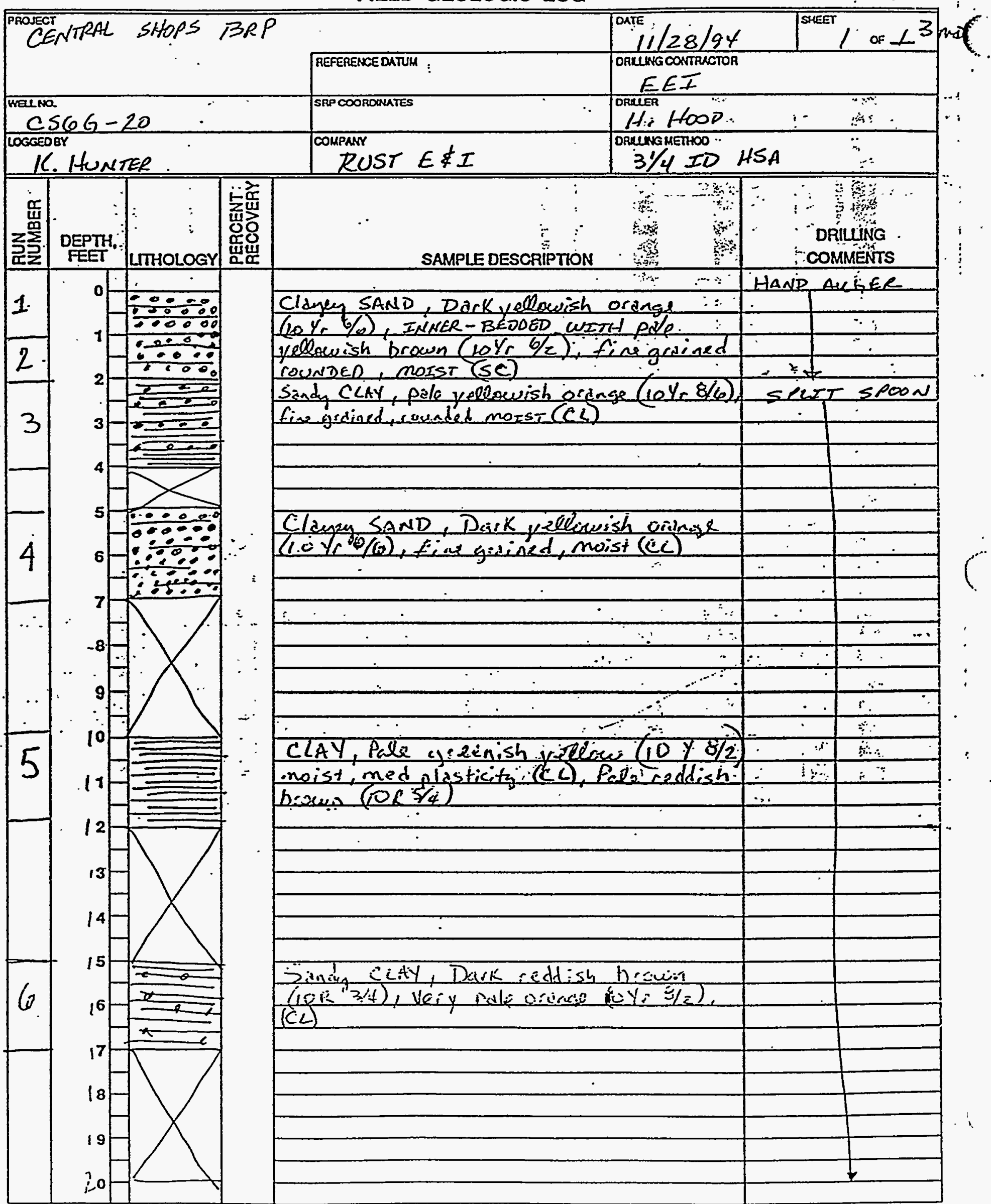


FIELD GEOLOGIC LOG

PEOEET CENTRAL SHOPS BRP

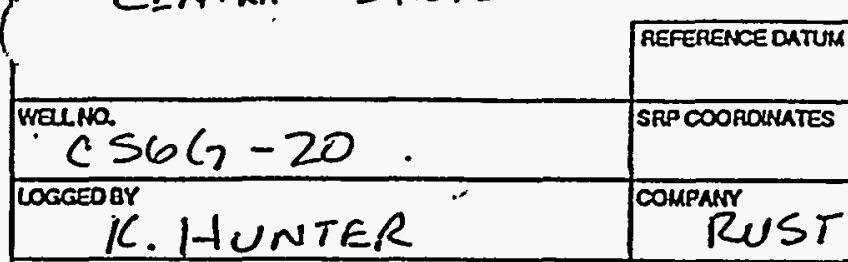

\begin{tabular}{|c|c|c|}
\hline & DATE $11 / 30 / 94^{\circ}$ & 2 or 3 \\
\hline & \multicolumn{2}{|l|}{$\begin{array}{l}\text { DRRLWG CONTRMCTOR } \\
\text { EEI }\end{array}$} \\
\hline & $\begin{array}{r}\text { ORRLER } \\
\text { if. } 1+0 O D\end{array}$ & . \\
\hline$E \notin I$ & 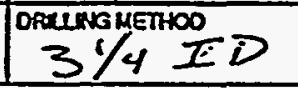 & $15 A$ \\
\hline
\end{tabular}

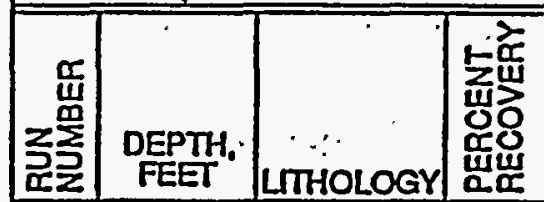

DRILLING .

7

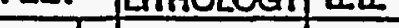

$\therefore$ SAMPLE DESCRIPTION

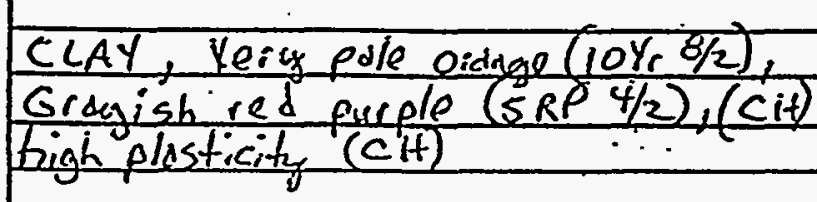

8
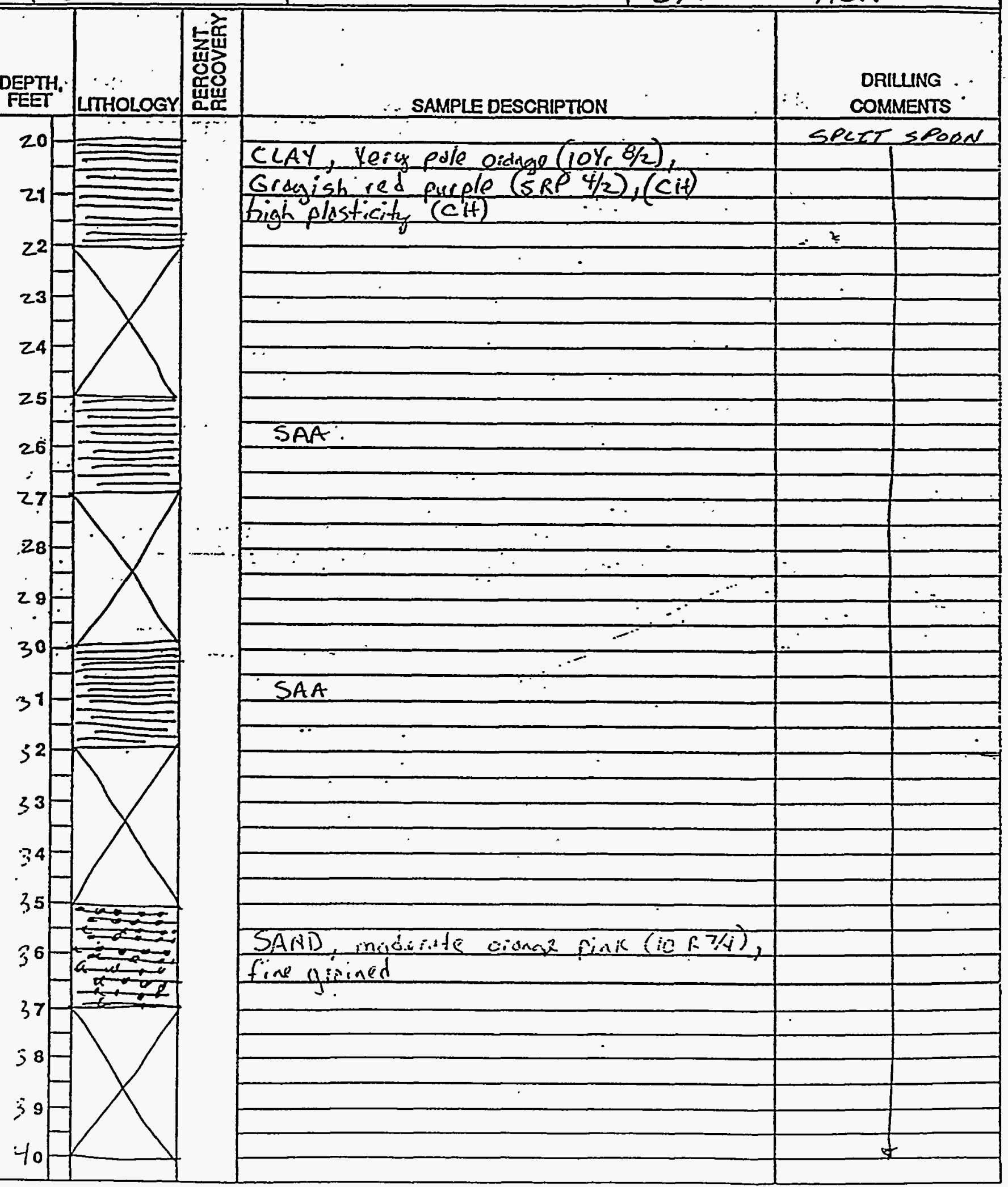
OSR30-s

FIELD GEOLOGIC LOG

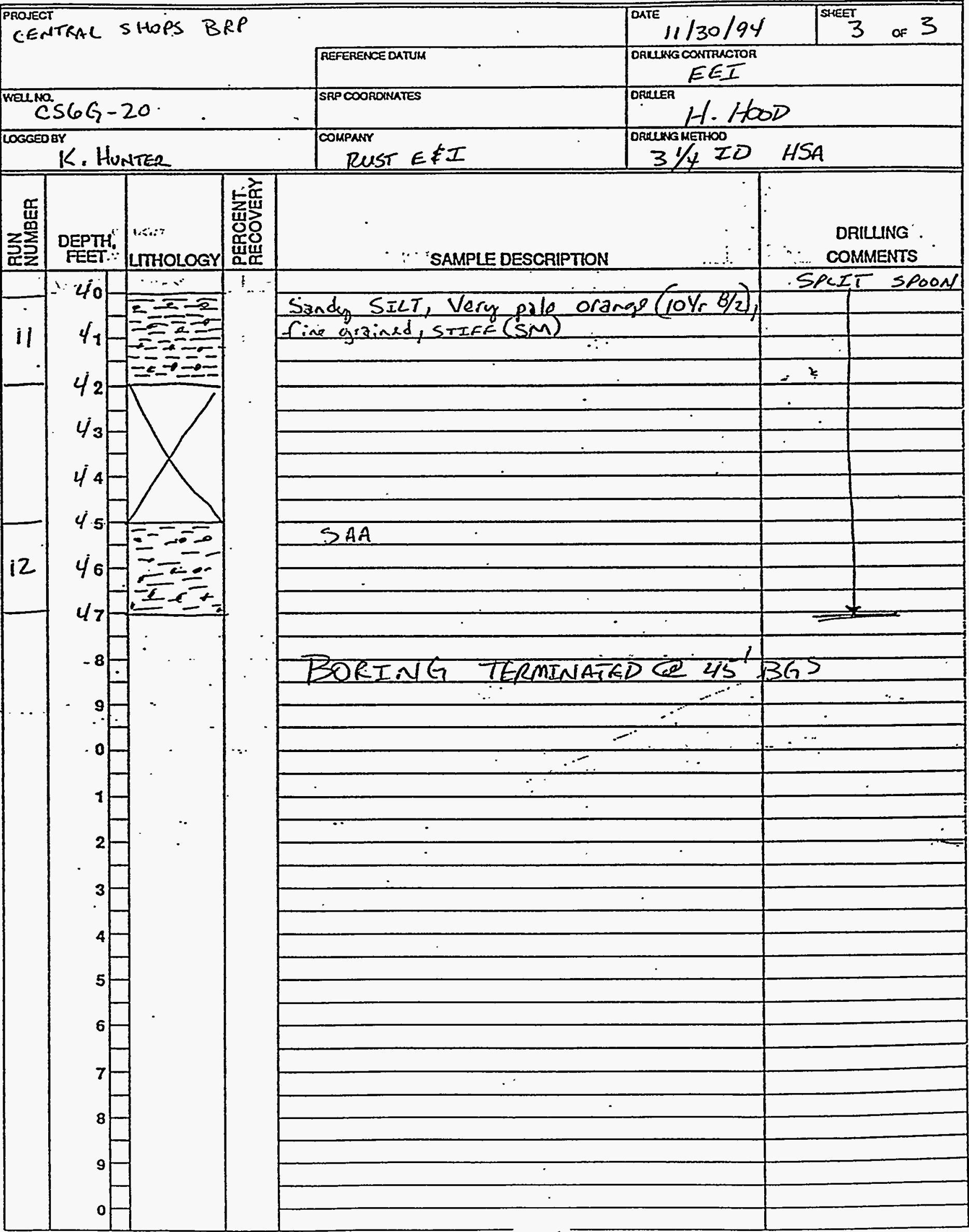


CS6G-21

.

(

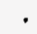

'

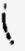


SRS SOIL BORING INSTALLATION REPORT

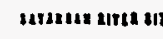

BURN FNG RUBBLE PIT:

\section{Project Manager}

CENTEAL SHOPS BURNENG RUBBLE PIT:

Boring Puipose

SOIL SAMPLENG

RAY PLUNKET

Department

Location Doscription

CEEATEAL SHOPS ARART.

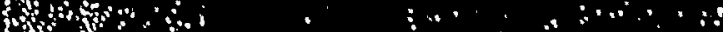

SRS North Grdd Coordinate

SRS East Gidd Coordinalo

.. Laltude (docimal dogroos)

Longitude (declmal degrees) i

Ground Elovallon

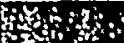

Total Dilllad Doplh

45

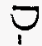

\begin{tabular}{cc} 
NA \\
\hline Semple Typo \\
\hline Sampling inlerva
\end{tabular}

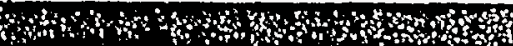

נis

HAND PULER

SPLIT SPOON.

\begin{tabular}{|cc|}
\hline$: i$ & $i l$ \\
\hline 4 & 11 \\
\hline 4 & 11 \\
\hline 4 & 4 \\
\hline $1 i$ & 1 \\
\hline 11 & 4 \\
\hline
\end{tabular}

$\frac{0-1}{1-2}$

$4-4$

$5-7$

Orilling Company

$\therefore$ ET

$10-12$

$15-17$

$20-22$

$2.5-2.7$

$30-32$

Disposition of Samples

GENERAL ENTINEERTNA LABORATORTES

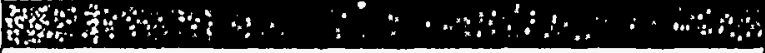

Mathod ol Abandonment

PRESSURR GroUT-TRIMARE

Materials Used In Abandonment

\section{A}

Abandonment Verilled By

2. HUNTER

ABANDONMENT

Drilling Móthod : $1 / 4$ IDA

Drilling \& Sempling Comments

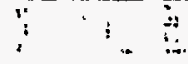
Detilling Start Dato, - Deflling Complellion Dato Semplo Typo Sampling Intorval

Include drilling muds used, source of wyater, lost cliculallon zones, ele.

\begin{tabular}{|c|c|c|}
\hline SPLET $3800 N$ & $40-42$ \\
\hline $4 !$ & $\vdots .6$ & $45-4.7$ \\
\hline$\vdots$ & $\vdots$ &
\end{tabular}

प

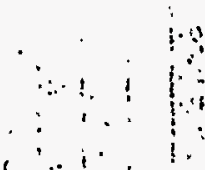

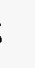

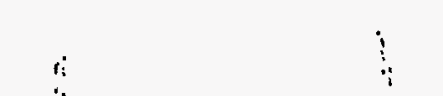

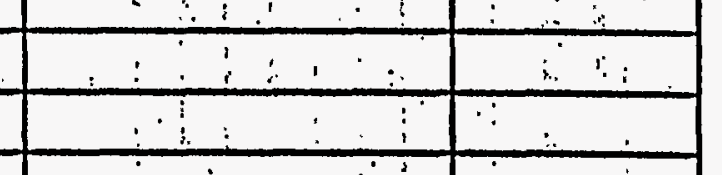

Drillor (lest name, lirst Initlal) Ovoralght Cọmpany

1

x.te SLuppy Gevid i: 
FIELD GEOLOGIC LOG

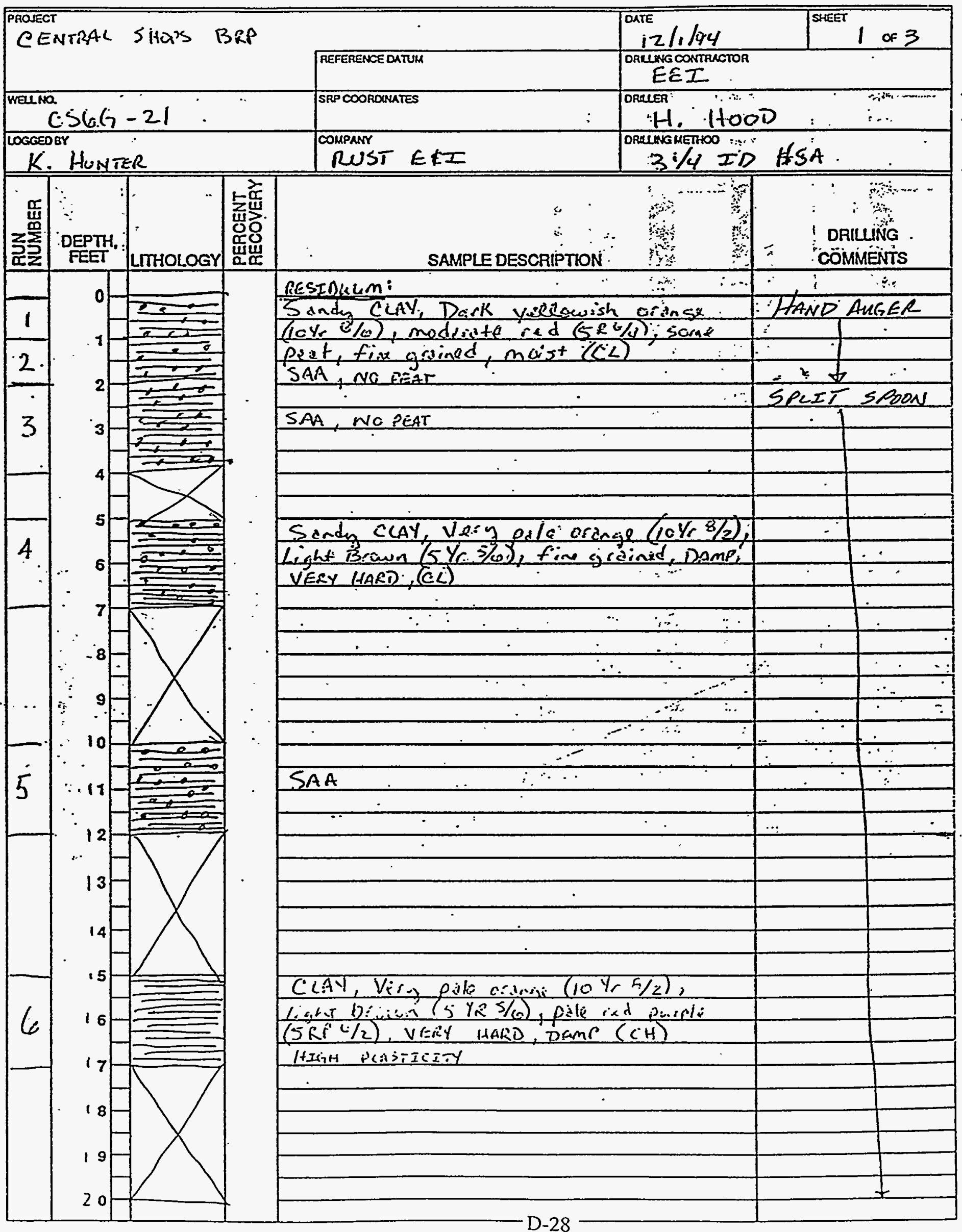


FIELD GEOLOGIC LOG

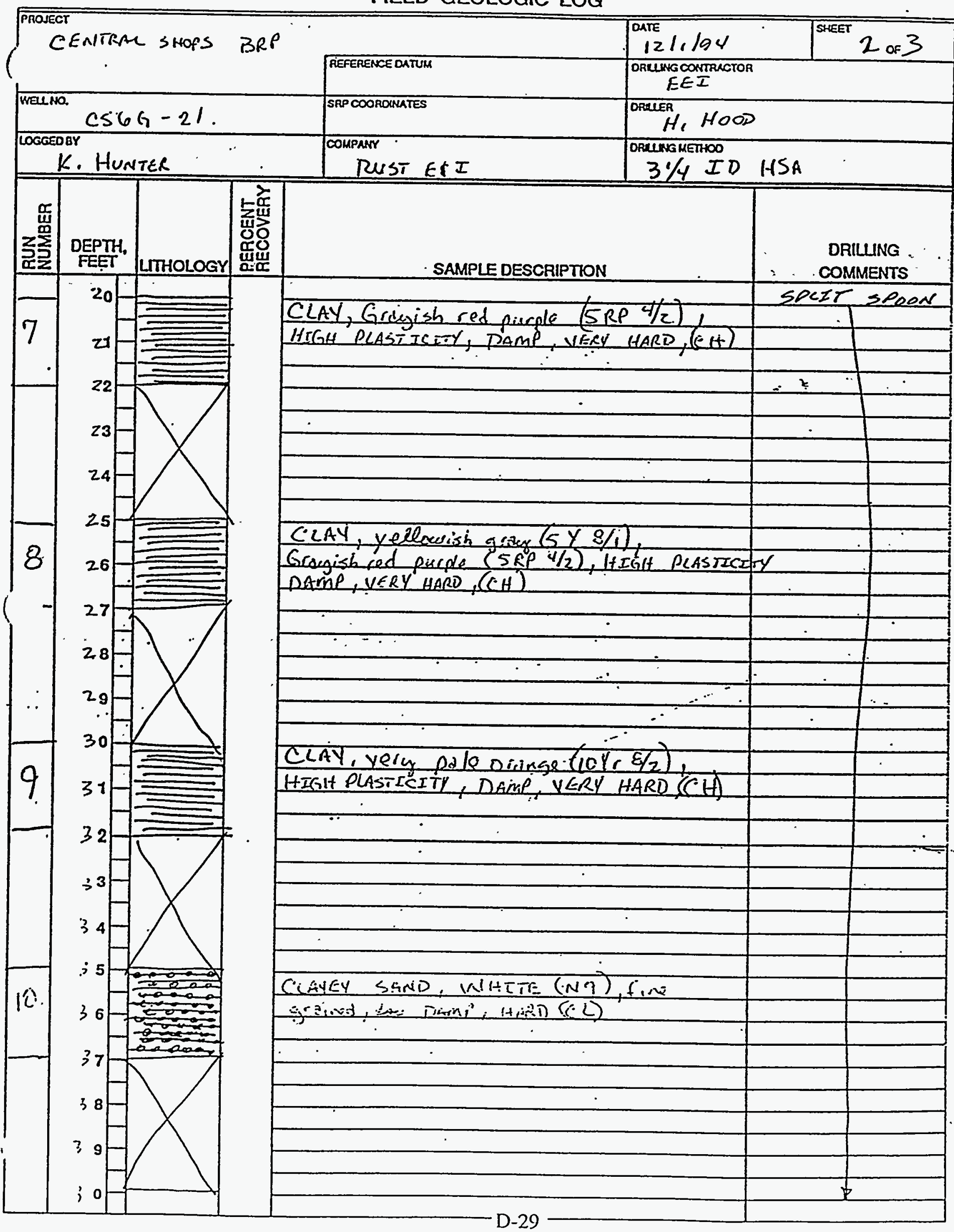


FIELD GEOLOGIC LOG

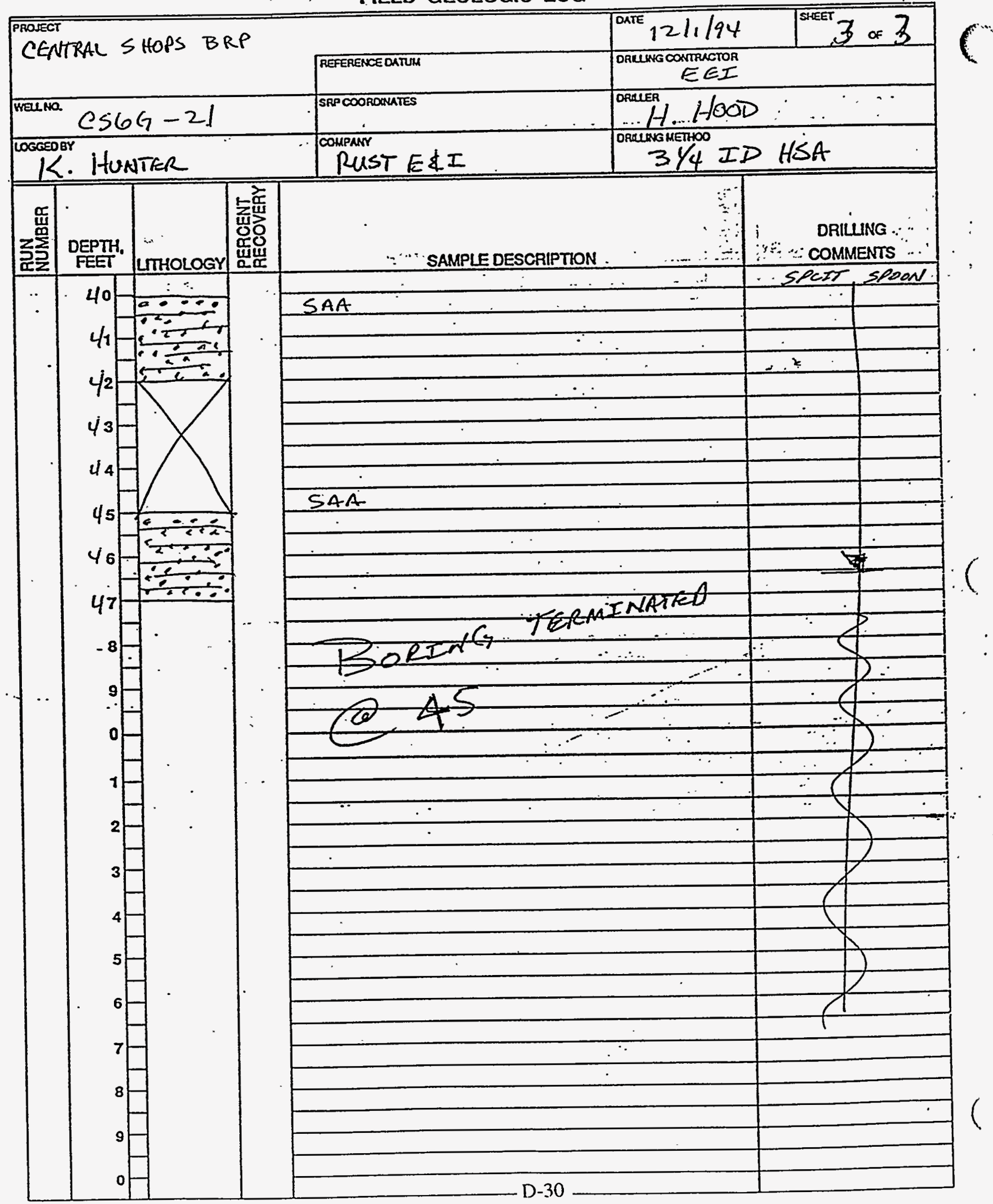


CS6G-22 


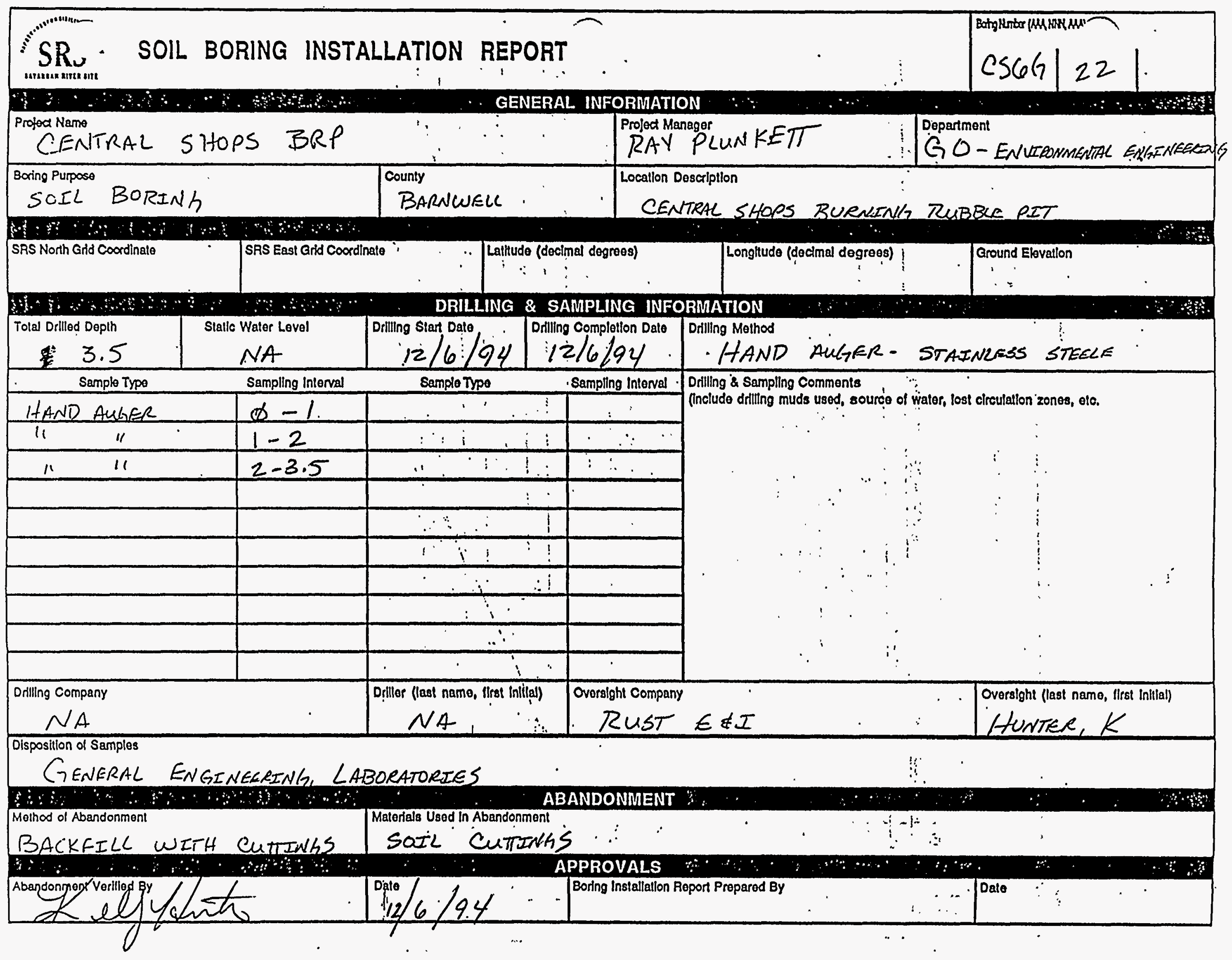


FIELD GEOLOGIC LOG

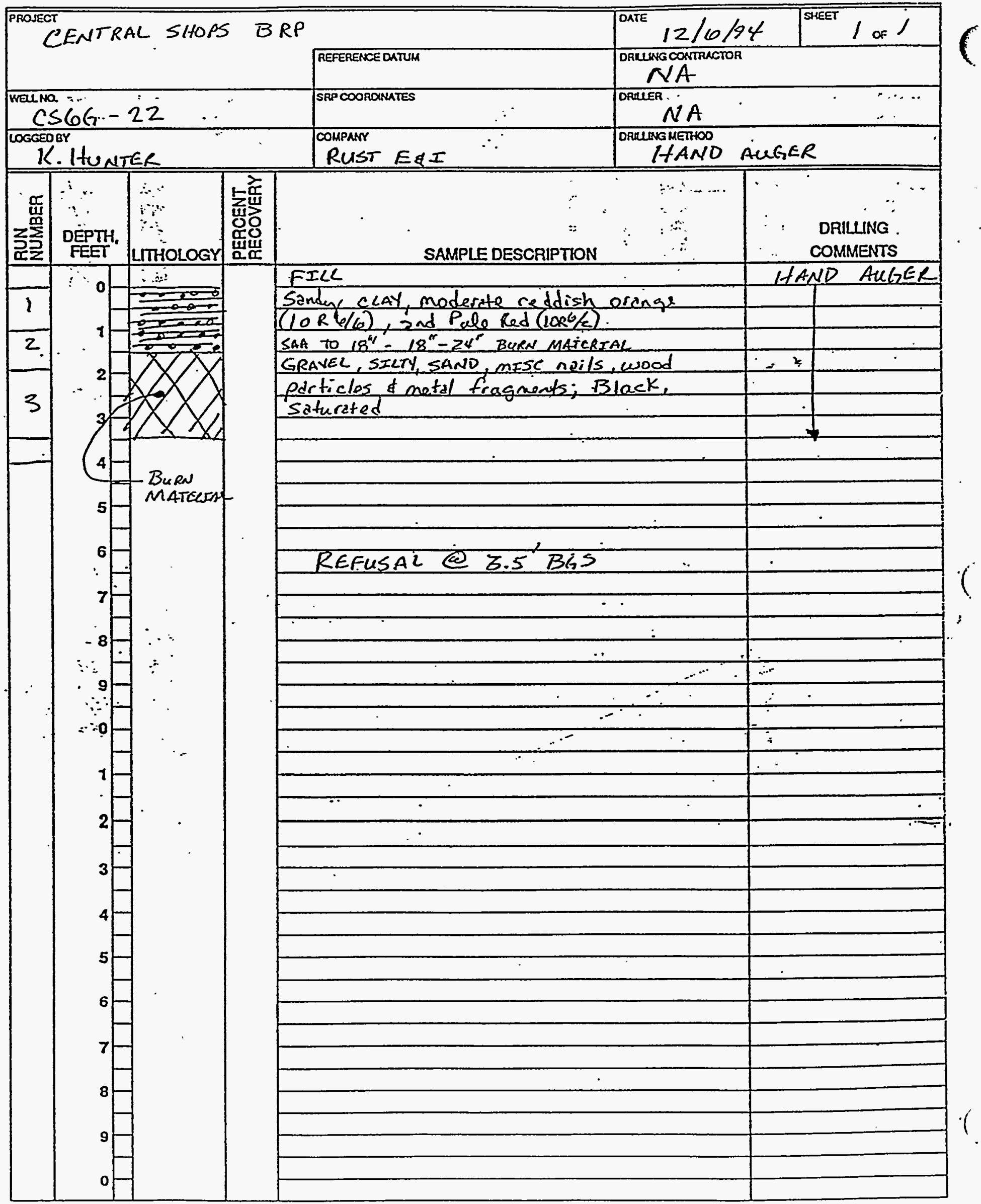


Appendix E

Daily Sign-In/Out Logs and Work Zone Entry/Exit Logs 
Daily Sign-In/Out Logs

(

? 
PROJECT: 8835L 000

PROJECT NO.: CEATRAL LEWPS BRP

SITE LOCATION:

HSO: K. LUNTER

DATE: $11 / 2 / 94$

PAGENO: of

TAME

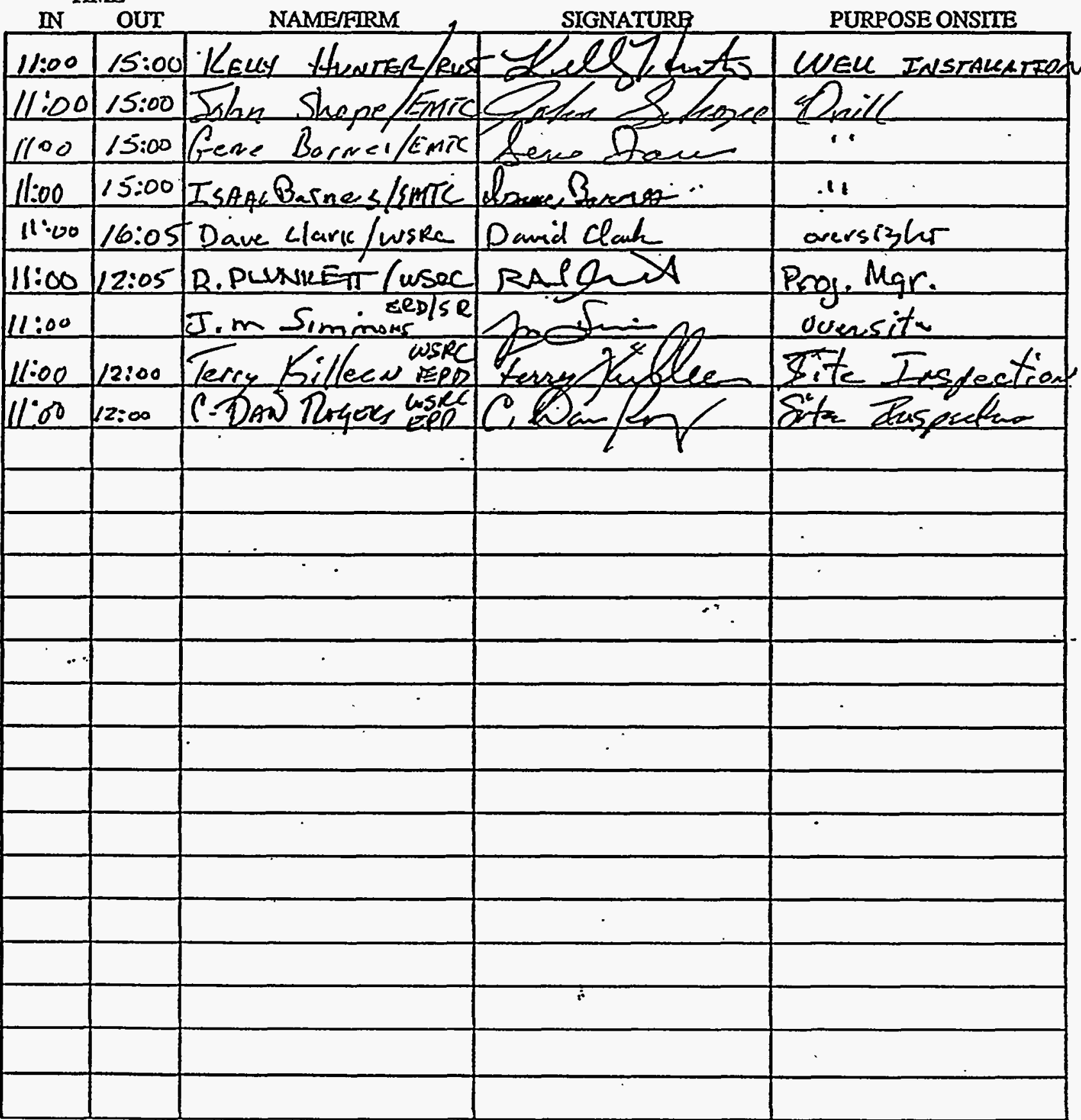

Note: This form is to be completed on a daily basis by all personnel working on the site. 
PROJECT: Central Shops BRP, 63I-6G RI

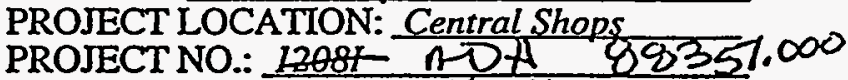
SITE SAFETY, OFFICER: $R$. AUNTER

DATE: $11 / 3 / 94$

PAGENO: 1 of $1=$

\begin{tabular}{|c|c|c|c|c|}
\hline \multicolumn{2}{|c|}{ TAME } & \\
\hline IN & OUT & $\cdots$ NAME & FIRM & PURPOSE ONSITE \\
\hline$=9: 2.5$ & 1700 & KELLY ItUNTER $\because "$ & RUST & WELC INSTALLATLON \\
\hline 720 & $1700 \therefore$ & Gene $\operatorname{Rern} x$ & $E M+c$ & $\operatorname{DriL}$ \\
\hline $7: 30$ & 1700 & Ionathan Slaspe & EATTC & Pric \\
\hline $7: 30$ & 1700 & IsaAc Baraes & $\operatorname{EnT} \mathrm{C}^{\circ}$ & Drill \\
\hline $8: 00$ & $16: 30$ & Dave Clark & WSRe & oversight \\
\hline $9: 00$ & $9: 10$ & Driay / Jencests & $\mu S R C$ & $R(d)$ \\
\hline $9: 00$ & $9: 25$ & Elasine Bensett & wSRC & salett \\
\hline $9 \cdot 28$ & $9: 25$ & Brian K. Lewis & WSRC & Eet y \\
\hline $9: 38$ & $9: 45$ & Tanelle Tanssein & WSRC & progress status rept. \\
\hline $9+0$ & $10^{00}$ & IAMES \& ALSERWS & $4+526$ & VISLE WATER \\
\hline $10: 10$ & 10.40 & RPlunket & WSEC & PROJ MGR \\
\hline $.2: 02$ & $2: 30$ & m. Simmons & ERD/DOE & .ouchite \\
\hline 2215 & $3: 00$ & Chet Nichols & UISAC & Mob:12/log60ot \\
\hline $2: 30$ & & Pr. Sproming - & ERo/Daces & \\
\hline$\because$ & & & . & \\
\hline & & & & \\
\hline & & $\therefore$ & & \\
\hline & & & & \\
\hline & , & . & & \\
\hline & $\cdot$ & & & \\
\hline & & & & \\
\hline & & & & \\
\hline & & & & \\
\hline & & & & \\
\hline & & & & \\
\hline
\end{tabular}

Note: This form is to be completed on a daily basis by all personnel working on the site. 


\section{DAILY SIGN-IN/OUT LOG}

PROJECT: Central Shops BRP. 63I-6G RI PROJECT LOCATION: Central Shops

PROJECT NO.: $1208+$ NN 4 Q4357. SITE SAFETY OFEICER: Kell Hirarer

DATE:

PAGE NO:: I of । $=$

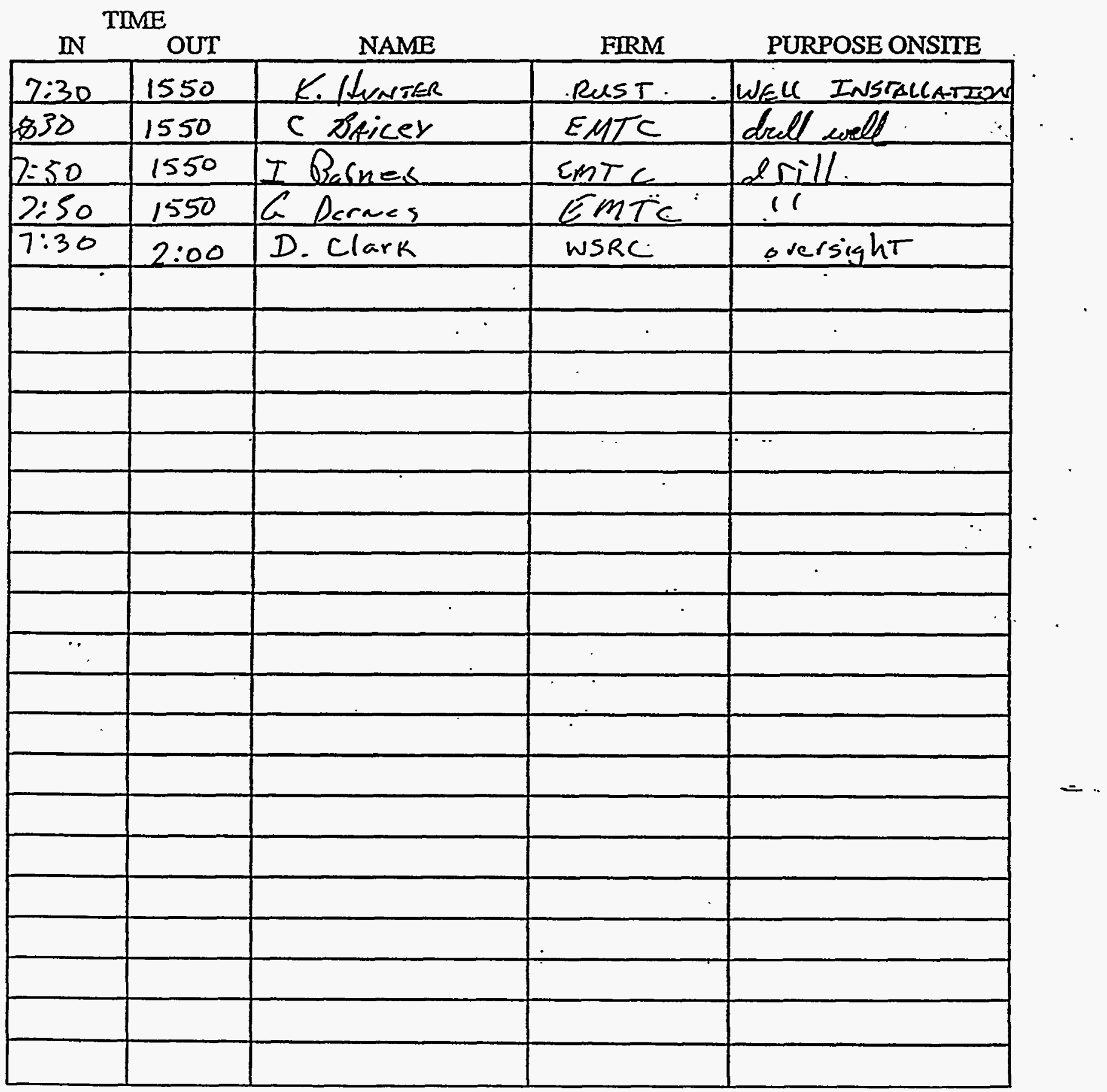

Note: This form is to be completed on a daily basis by all personnel working on the site. 
DAILY SIGN-IN/OUT LOG

PROJECT: Central Shops BRP, 631-6G RI PROJECT LOCATION: Central Shops

PROJECT NO.: I208T NAH 89351.000

SITE SAFETY OFFICER: KL, AUN/TER DATE: $11 / 4 / 94$

PAGE NO.:

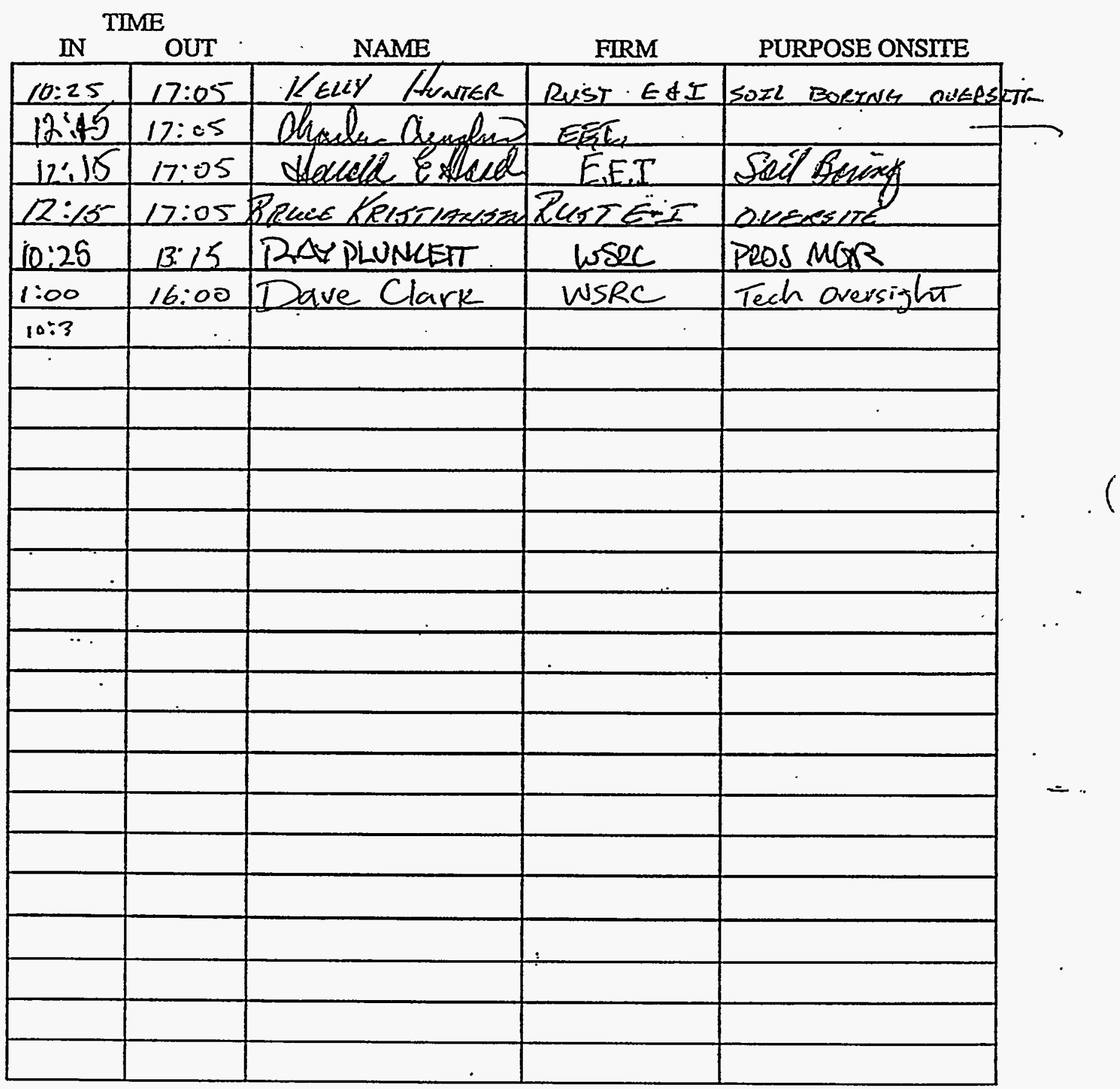

Note: This form is to be completed on a daily basis by all personnel working on the site. 
PROJECT: Central Shops BRP. 63I-6G RI PROJECT LOCATION: Central Shops PROJECT NO.: $12081 \mathrm{n}$ D i 08357.000 SITE SAFETY OFFICER: $K$, LK, DATE:

PAGE NO.:

\begin{tabular}{|c|c|c|c|c|}
\hline \multicolumn{2}{|c|}{ TIME } & NAME & FIRM & PURPOSE ONSETE \\
\hline $7: 05$ & $1: 00$ & 1L. IfÜNTER & RUST & SOIL BORING \\
\hline $8: 35$ & $2: 30$ & D CCARK & WSRC & Oersight \\
\hline $0 ; 00$ & $15: \infty$ & Q CRENSHIAW & $E E I$ & Sere But2 ine \\
\hline $7: 000$ & $15: 00$ & A 6000 & $E E T$. & $50^{\circ}$ L Barina \\
\hline 7:05 & $15: 30$ & B. Kristanson & RUST EII & $\cdots$ \\
\hline 9.55 & $10: 20$ & \$. CHEEK & UNSRC EPD & ONERSic,HT \\
\hline $10: 33$ & $2: 30$ & R.Plunkeft & wsec & PROj MiR \\
\hline$-10: 30$ & $11: 25$ & H. dmith & wstec & $9 A$ \\
\hline $9: 30$ & $11: 25$ & Lenre Heszlow & $\omega \sec$ & RA \\
\hline $9: 30$ & $11: 25$ & Nickic Palmer & WSRE & 201 \\
\hline $1: 20$ & $2: 15$ & Donnan Breumky & DOE & oversite \\
\hline$i: 20$ & $2: 15$ & mike Simman & $D O E-E R$ & -uersite \\
\hline $2: 10$ & $2: 30$ & Shaven Eulfor & WSPR /ERD & Suppont \\
\hline ". & & & & . \\
\hline & & & & \\
\hline & & & ; & \\
\hline & & & & \\
\hline & & & & \\
\hline & & & & \\
\hline & & & & \\
\hline & & & & \\
\hline & & & & \\
\hline & & & & \\
\hline & & & & \\
\hline
\end{tabular}

Note: This form is to be completed on a daily basis by all personnel working on the site. 
PROJECT: Central Shops BRP. 631-6G RI

PROJECT LOCATION: Central Shops

PROJECT NO.* $\$ 8835.000$

SITE SAFETY OFFICER: $K$. HUNTER

DATE: $11 / 16 / 94$

PAGE NO:

\begin{tabular}{|c|c|c|c|c|}
\hline $\mathbb{I N}$ & OUT & NAME & FIRM & PURPOSE ONSITE \\
\hline $6: 58$ & $14: 00$ & Kelcy (tuntar & RUST EEI & SOEC BORINGG \\
\hline $7: 20$ & $14: 00$ & BAROID HeCD & E.E. & Seíl Boríng \\
\hline 21000 & 14:00 & (AHARIES CREUSSIAC) & EEI & so, BORINig \\
\hline $9: 15$ & $13: 00$ & Dave Clark & wsRC & oversight \\
\hline $9: 55$ & $13: 20$ & Laura tiaselow & WSRe & Back jrund dentfiat \\
\hline $9: 55$ & $13: 50$ & Nickie Palmer & WSRC & $\therefore$ \\
\hline $9: 55$ & $13: 50$ & Vergil Rogers & WSRC & 11 \\
\hline$\hat{0 \neq 0}$ & $\angle \%=0$ & 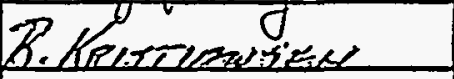 & Puster & 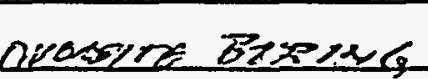 \\
\hline & & & & \\
\hline & & & & \\
\hline & & & & \\
\hline & & & & . \\
\hline - & & & & \\
\hline & & & & \\
\hline & & & & \\
\hline & & & & \\
\hline & & & & \\
\hline & & & & : \\
\hline & & & & \\
\hline & & & & \\
\hline & & & & \\
\hline & & & & \\
\hline & & & & \\
\hline & & & & \\
\hline & & & & \\
\hline
\end{tabular}

Note: This form is to be completed on a daily basis by all personnel working on the site. 


\section{DAILY SIGN-IN/OUT LOG}

PROJECT: Central Shops BRP. 63I-6G RI PROJECT LOCATION: Central Shops

PROJECT NO.: $\$ 2081$ (1)N 9020357.000 SITE SAFETY OFFICER: K. Hu DATE: $11 \sqrt{1 7 \longdiv { 9 4 }}$

PAGE NO: 1 of I

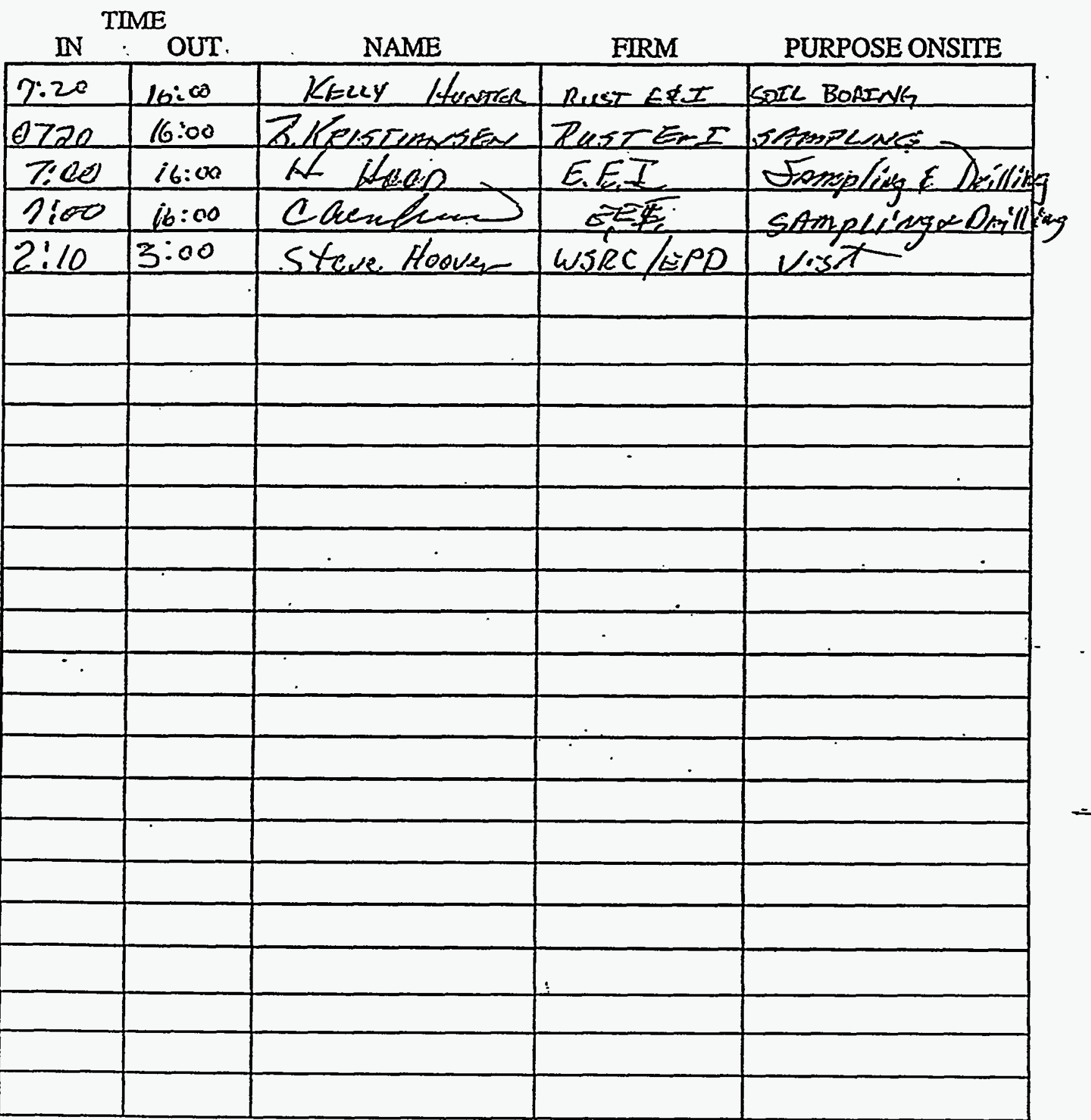

Note: This form is to be completed on a daily basis by all personnel working on the site. 
DAILY SIGN-IN/OUT LOG

PROJECT: Central Shops BRP, 63I-6G RI

PROJECT LOCATION: Central Shops

PROJECT NO.: $12081 \mathrm{MDN}$ EQ0 355.000

SITE SAFETY OFIICER: $K$. HUNTER

DATE: $11 . / 18 / 94$

PAGE NO.: 1 of $1=$

TTME

\begin{tabular}{|c|c|c|c|c|}
\hline $\mathbf{I N}$ & OUT & NAME & FIRM & PURPOSE ONSTIE \\
\hline $7: \infty$ & 1500 & KEUV - HUNTER & Rusr EAI & SOTC BJRENAGS \\
\hline $7: 35$ & $9: 35$ & R Pluakety & wsec & PROJ MGR \\
\hline $723 S$ & 9.30 & D. Clarke & wisec & OVIESLGEIT SGS \\
\hline-7.00 & $24: 00$ & H. Hotes & $E E, Z$ & Dr. Ilia \\
\hline nepl & $14: 00$ & nes. & $E E I$ & Didillese \\
\hline $9: 00$ & $9: 35$ & if & $S R F S$ & Ifftrusel Mesent Rest \\
\hline$[2: 20$ & $12 \cdot 40$ & Cave Heselow & usac & Field visit \\
\hline $11: 20$ & 12.48 & Mhark Auajgue6er & RUST & Fear, visiar \\
\hline $11: 20$ & $12: 40$ & Steve Dilland & RUST EFI & Feld vioit \\
\hline 16.00 & $12: 40$ & Karfiemp TACHZL & Rust EUI & Field vis." \\
\hline 1.80 & $12: 40$ & Vergil Regers & WIRC & Eiseld visit \\
\hline $11: 20$ & $12: 40$ & LARRE NeGL & Rust E\&E & Field vicit \\
\hline 0730 & 1500 & B-terarisorex & PCortzZ & Pore Bureerss \\
\hline$\because$ & & & & \\
\hline & & & & \\
\hline & & & 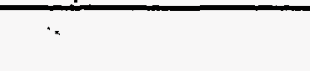 & \\
\hline & & & & \\
\hline & & & & \\
\hline & & & & \\
\hline & & & & \\
\hline & & & & \\
\hline & & & & \\
\hline & & & & \\
\hline & & & & \\
\hline
\end{tabular}

Note: This form is to be completed on a daily basis by all personnel working on the site. 
PROJECT: Central Shops BRP, 63I-6G RI

PROJECT LOCATION: Central Shops

PROJECT NO.: $1208 \% \mathrm{MDA}$ 880357.000

SITE SAFETY OFFICER: $k$ HuNTER

DATE: $11 / 22 / 94$

PAGE NO.:

$=$

\begin{tabular}{|c|c|c|c|c|}
\hline $\mathrm{IN}$ & OUT & NAME & FIRM & PURPOSE ONSITE \\
\hline $7: 20$ & 1545 & E.E.L Hosed & $E . E \bar{C}$ & Uresforarg \\
\hline 2,00 & 1545 & 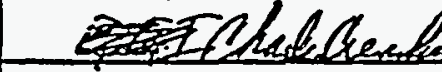 & $\triangle E E L$ & PRilling - \\
\hline 0700 & 1545 & Bruce Kelszemser & 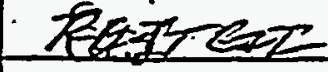 & Stasion< \\
\hline $07: 10$ & 1545 & Kracy Hunter & RUST E $E I$ & SAMPCING \\
\hline $07: 30$ & 1545 & Dave Clark & wisec & oversight \\
\hline & & & & - \\
\hline & & & & . \\
\hline & & & & \\
\hline & & & & \\
\hline & & & & \\
\hline & & & & \\
\hline & & & & \\
\hline & & & & \\
\hline$\because$ & - & & & \\
\hline & & & & \\
\hline & & & & \\
\hline & & & & \\
\hline & & & & \\
\hline & & & & \\
\hline & & & & \\
\hline & & & & \\
\hline & & & & \\
\hline & & & & \\
\hline & & & & \\
\hline
\end{tabular}

Note: This form is to be completed on a daily basis by all personnel working on the site. 


\section{DAILY SIGN-IN/OUT LOG}

PROJECT: Central Shops BRP, 63I-6G RI

PROJECT LOCATION: Central Shops

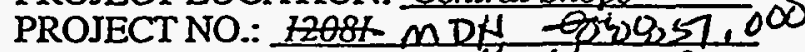

SITE SAFETY/OFFICER: K. HUATER

DATE:

PAGE NO: 1 of 1

\begin{tabular}{|c|c|c|c|c|}
\hline $\mathrm{IN}$ & Es & NAME & FाPM & PITRPSF ONSTTE \\
\hline $9 \cdot 9 n$ & 1400 & $\therefore$ H. H Hutser & $R \|<\epsilon A I$ & snte Ruetrlh \\
\hline$G^{2}, 0$ & 1400 & A. OAFUSIIAiD & .EEI & shoifisnas \\
\hline 0920 & 1400 & Blletirleseses & PuIF E- & Trmposines \\
\hline $09: 28$ & 1400 & 1. Hean & $E \cdot E: T$ & Drilliura \\
\hline & & & & \\
\hline & & & & \\
\hline & & & . & \\
\hline & & & & \\
\hline & & & & \\
\hline & & & & \\
\hline & & & & \\
\hline & & & & . \\
\hline & & & & \\
\hline & & & & \\
\hline$\ddot{\because}$ & & & & \\
\hline & & & & \\
\hline & & & & - \\
\hline & & & & \\
\hline & & & & \\
\hline & & & & \\
\hline & & & & \\
\hline & & & & \\
\hline & & & & \\
\hline & & & & \\
\hline & & & & \\
\hline
\end{tabular}

Note: This form is to be completed on a daily basis by all personnel working on the site. 
PROJECT: CENTRAC SHOPS BRP

PROJECT NO.: T2OET NDN 900357.000

SITE LOCATION: CEENTRAL SHOPS

HSO: K. HUNTER

DATE: $11 / 30 \mathrm{gYY}$

PAGENO.:

of

1

TIME

IN OUT

NAME/FIRM

SIGNATURE

PURPOSE ONSTTE

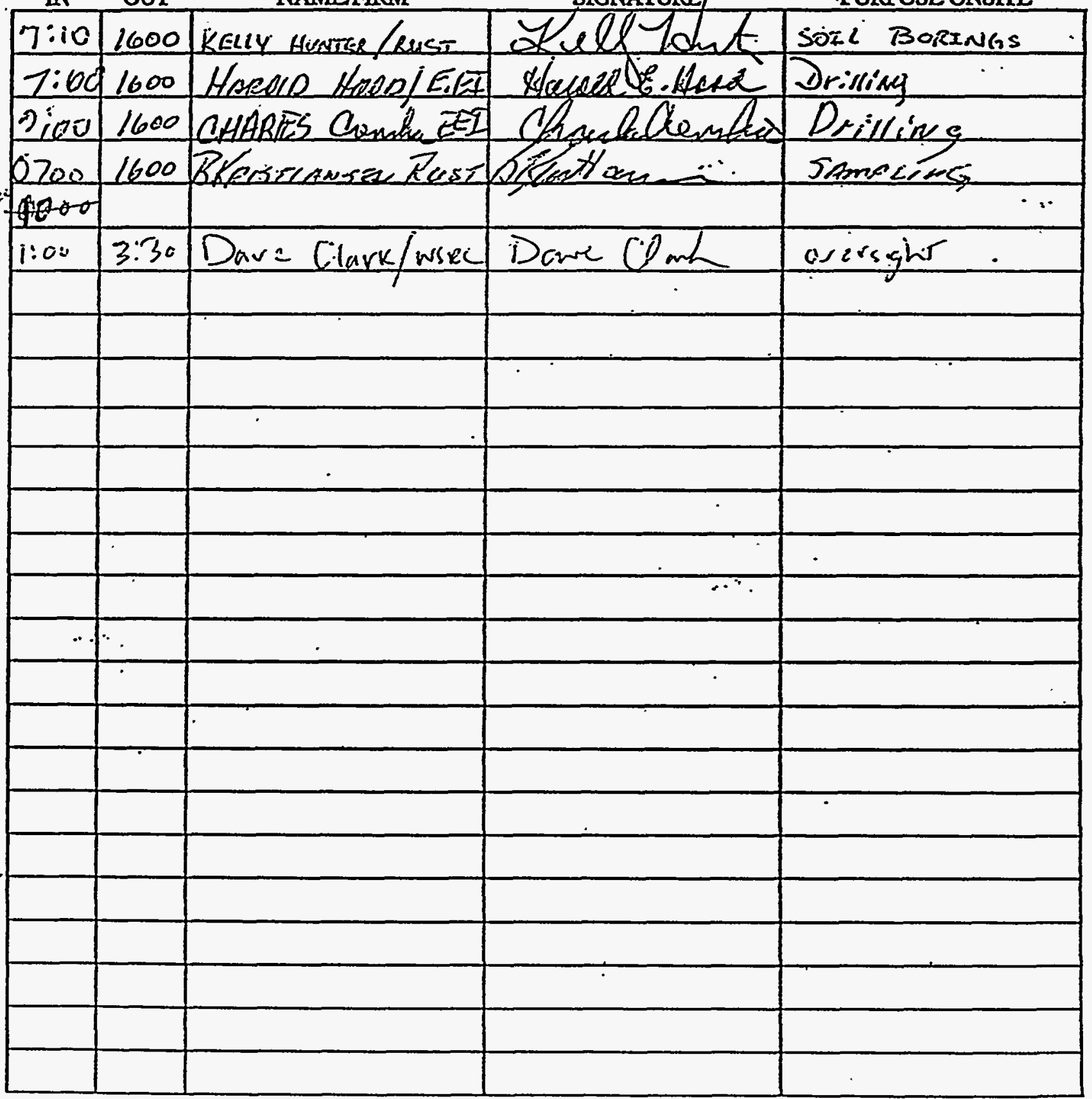

Note: This form is to be completed on a daily basis by all personnel working on the site. 
PROJECT: CENTRAL SHOSS BOP

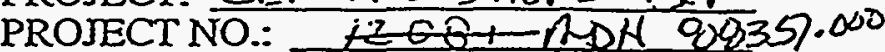

SITE LOCATION: CENTRAL SHAPS

HSO: $K$ I I UNTER

DATE: $12 / 1 / 941$

PAGENO: of 1 .

TIME

\begin{tabular}{|c|c|c|c|c|}
\hline IN & OUT & NAME/ERRM & SIGNATURE & PURPOSE ONSTIE \\
\hline $7: 55$ & 1600 & KRELYY HUNTER RUST EII & Yulk Tolus: & SOIL BORING \\
\hline 0800 & 1600 & 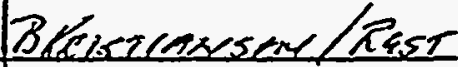 & sstencen & Sermpenes \\
\hline $07: 00$ & 1600 & Horedn Ased $\delta . E I I$ & Sacker Hoal & Driting \\
\hline Dile & $1600^{\circ}$ & 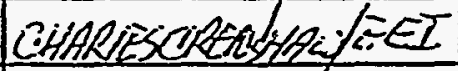 & Whalz Ckinstive & Liden \\
\hline OS:c0 & $1000_{c}$ & Dave Clark/cusiec & Dave Clanh & useristher... \\
\hline & & & & . \\
\hline & & & & \\
\hline & & & & \\
\hline & & & & \\
\hline & & & & \\
\hline & & & & \\
\hline & & & & \\
\hline & & & & \\
\hline & & & & \\
\hline & & & & \\
\hline & & & & \\
\hline & & & & \\
\hline & & & & \\
\hline & & & & \\
\hline & & & & \\
\hline & & & & \\
\hline & & & & \\
\hline & & & & \\
\hline & & & & $\therefore$ \\
\hline & & & & \\
\hline
\end{tabular}

Note: This form is to be completed on a daily basis by all personnel working on the site. 
PROJECT: CENTPAL SHOPS

PROJECT NO.: 1ZOET MDN 0J9357.000

SITE LOCATION: CENTRAL SHOPS

HSO: K. HUNTER

DATE: $12 / 4 / 94$

PAGENO: of 1 .

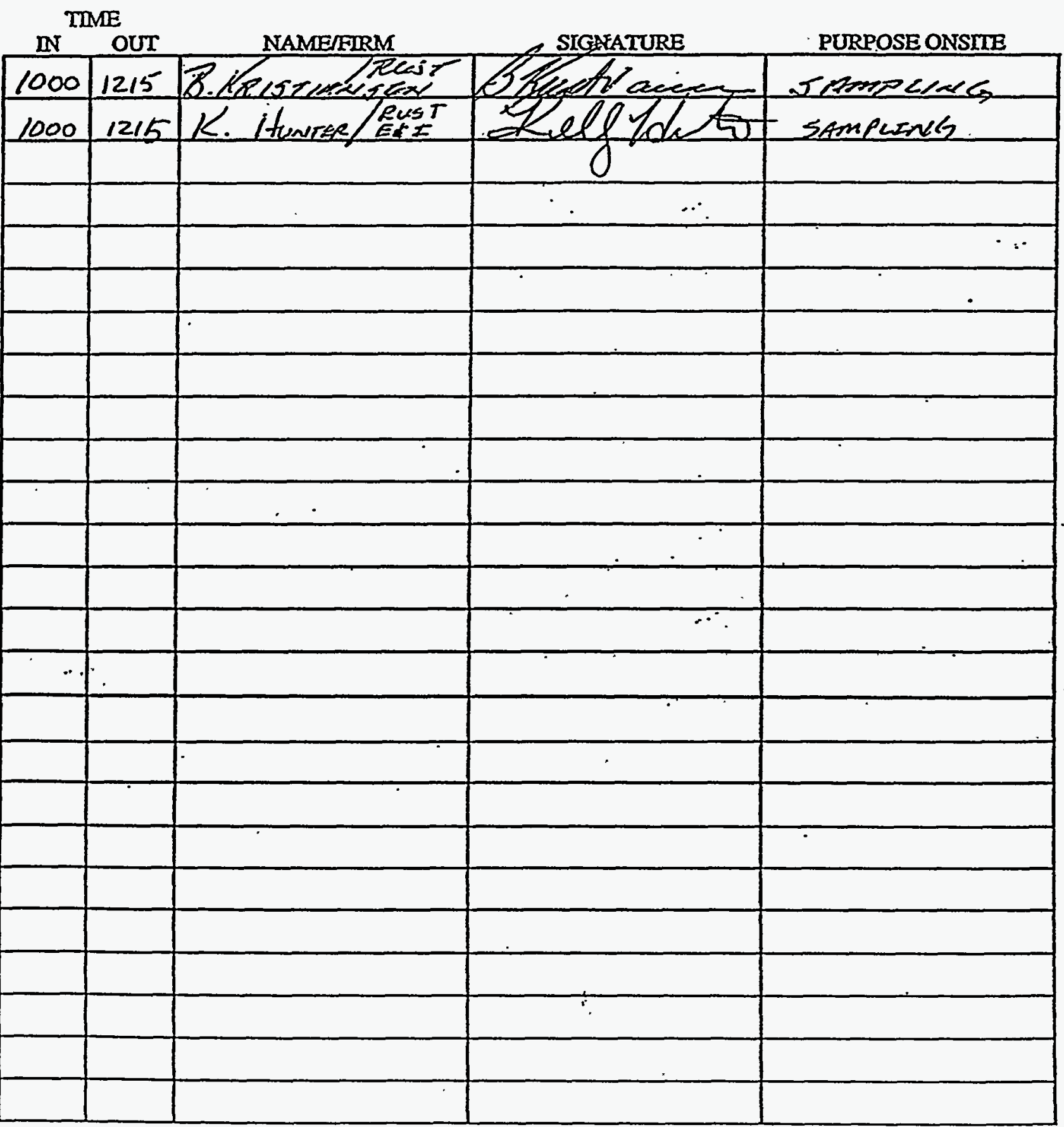

Note: This form is to be completed on a daily basis by all personnel working on the site. 
DAICX SIGN-IN/OUT LOG

PROJECT: CENTRAC SLTOES BRP

PROJECT NO.: tzo8t MDN \&90357-00

SITE LOCATION: CENTRAL SHOPS

HSO: $K$. ItyuteR

DATE: $12 / 5 / 94$

PAGENO.: 1 of

TIME

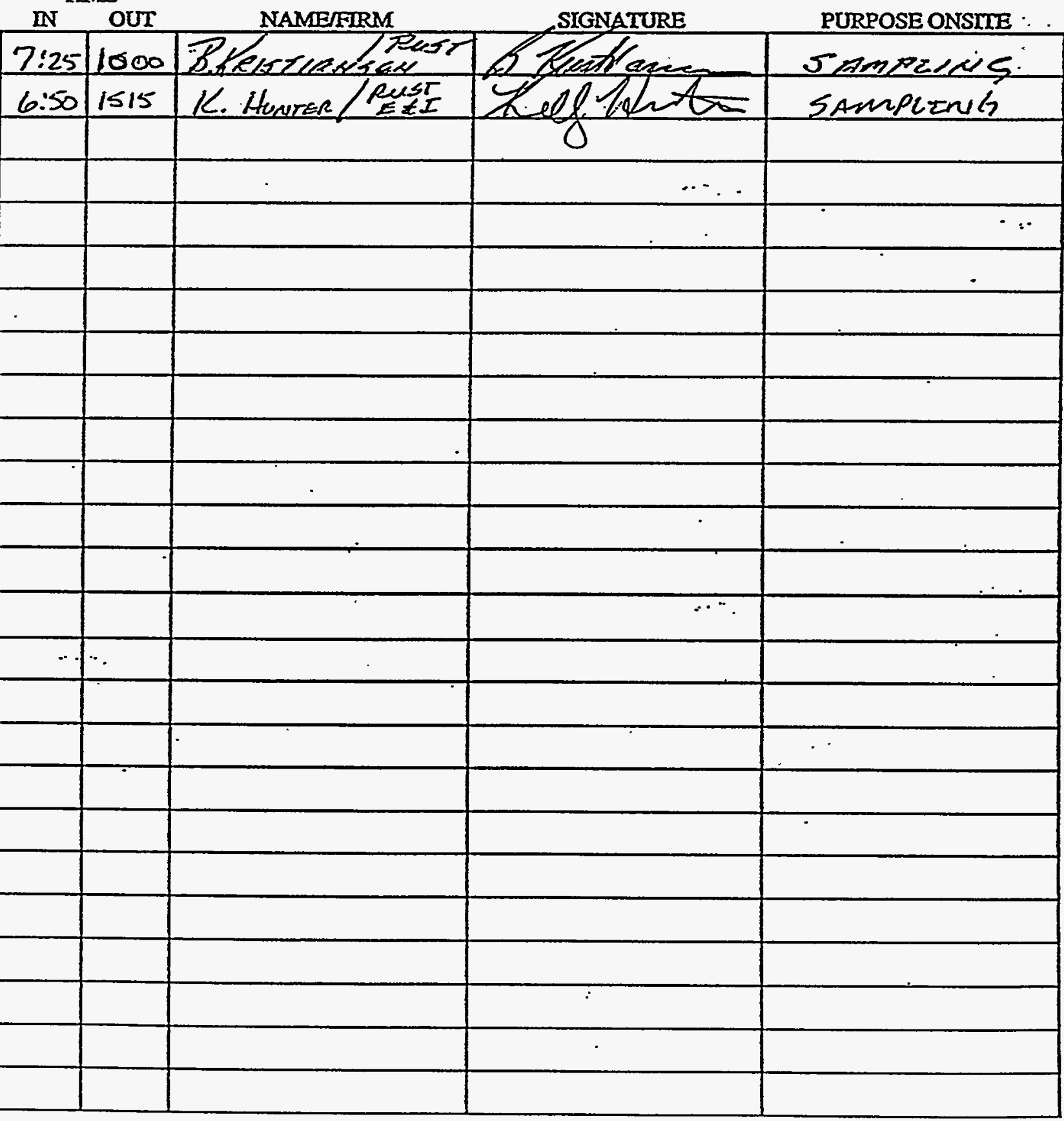

Note: This form is to be completed on a daily basis by all personnel working on the site. 
PROJECT: CENTRAL SHOPS BRP PROJECT NO.: LOSTMAN \&88357.680 SITE LOCATION: CENTRAL SHOPS HSO: K. HUNTER

DATE: $12 / 6 / 94$

PAGENO: of PURPOSE ONSTIE

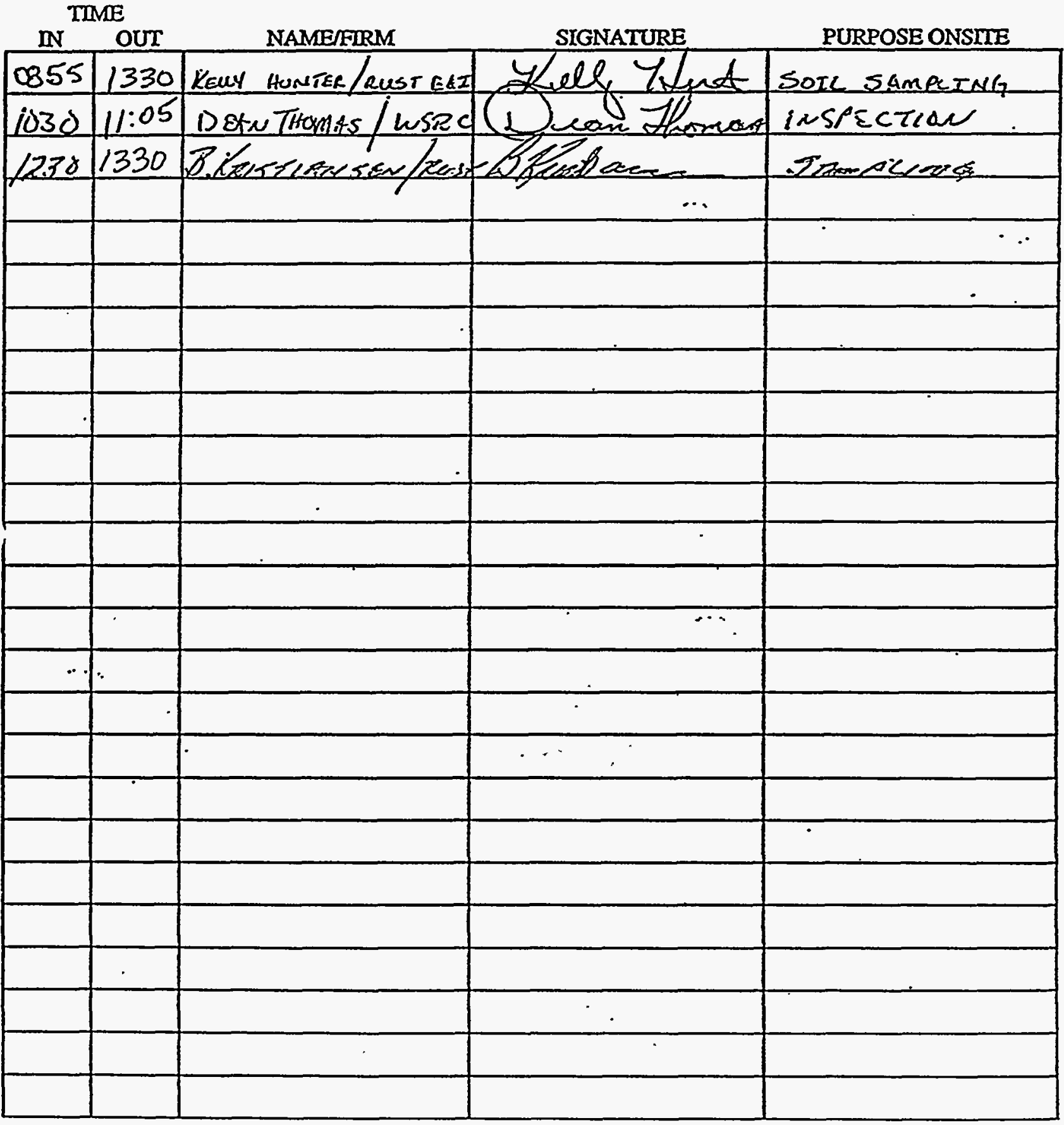

Note: This form is to be completed on a daily basis by all personnel working on the site. 
Work Zone Entry/Exit Logs 
PROJECT: CS BRP

PROJECT NO: KOOE INDA 900357.000

SITE LOCATION: CENT RAL SHOPS

HSO: K. HU NTER

DATE:

PAGE NO.:

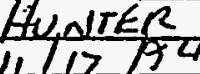

$:$ of

TTME

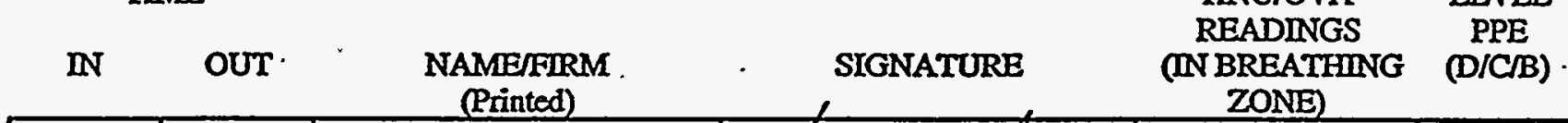

\begin{tabular}{|c|c|c|c|c|c|}
\hline $7: 00$ & $16: 00$ & E.E.I. & OtacldE, Haed & & \\
\hline 260 & $16: 00$ & EEE & chabuederifin & & \\
\hline Tika of & $\varepsilon \varepsilon, i t$ & LEIHEA & & & \\
\hline & & & & & \\
\hline & & & & & \\
\hline & & & & & \\
\hline & & & & & \\
\hline & & & & & \\
\hline & & & & & \\
\hline & & & & & \\
\hline & & & $\therefore$ & & \\
\hline & & & & & \\
\hline & & & & & \\
\hline & & & & & \\
\hline & & & & & \\
\hline & & & & & \\
\hline & & & & & \\
\hline & & & & & \\
\hline & & & & & \\
\hline & & & & & \\
\hline
\end{tabular}

Note: This form is to be completed on a daily basis by all onsite personnel working within the controlled work zone. 
WORK ZONE ENTRY AND EXIT LOG (JOB EXPOSURE REPORT)

PROJECT: CENTRAL SHOPS BRP, 63i-6GRI PROJECT NO.: CENTRAC SITOPS Q4357.00 SITE LOCATION: 12081

HSO: K. LTUNUTER

DATE: $11 / 22 / 92$

PAGE NO.:

TIME

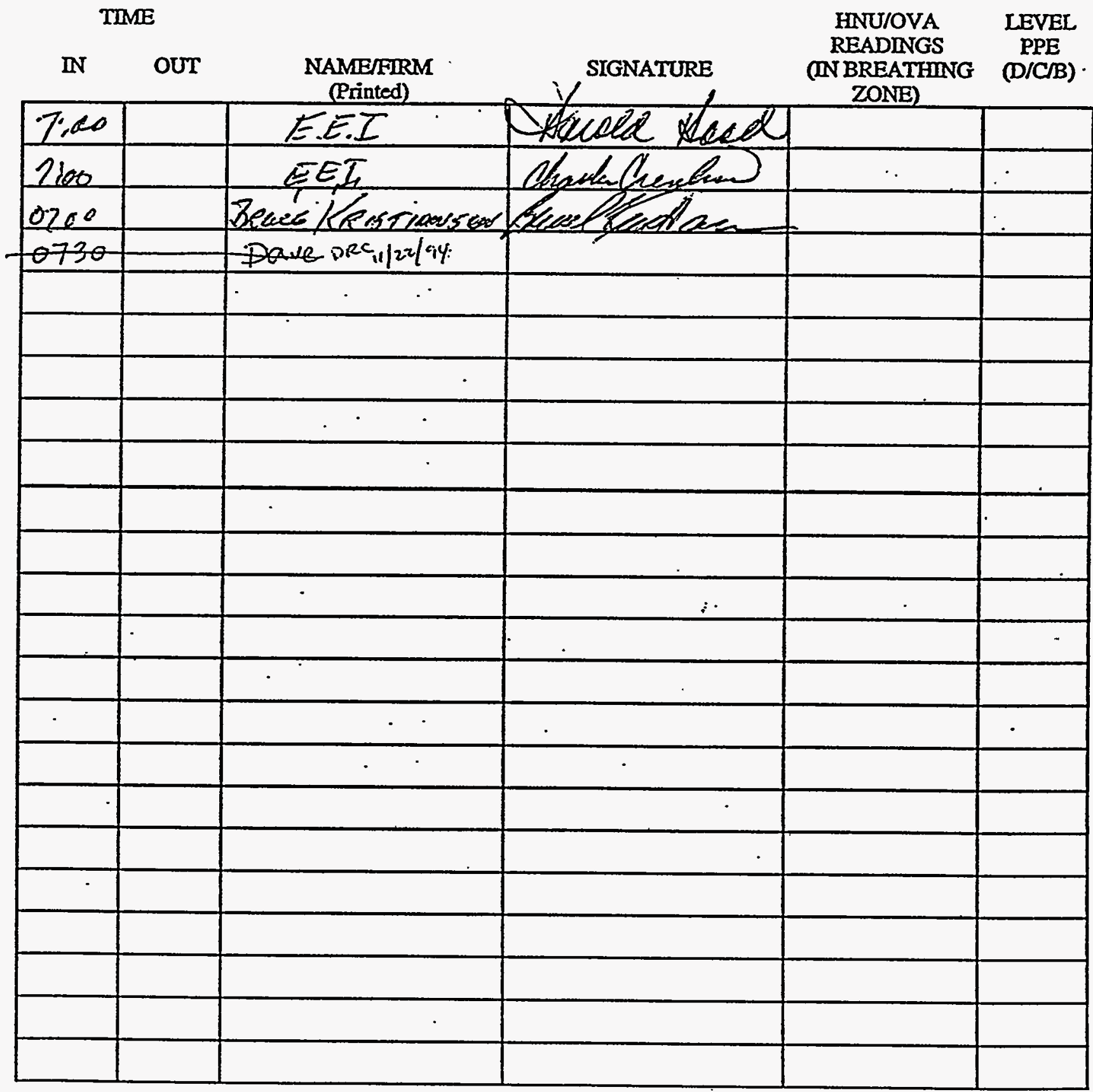

Note: This form is to be completed on a daily basis by all onsite personnel working within the controlled work zone. 
WORK ZONE ENTRY AND EXIT LOG. (JOB EXPOSURE REPORT)

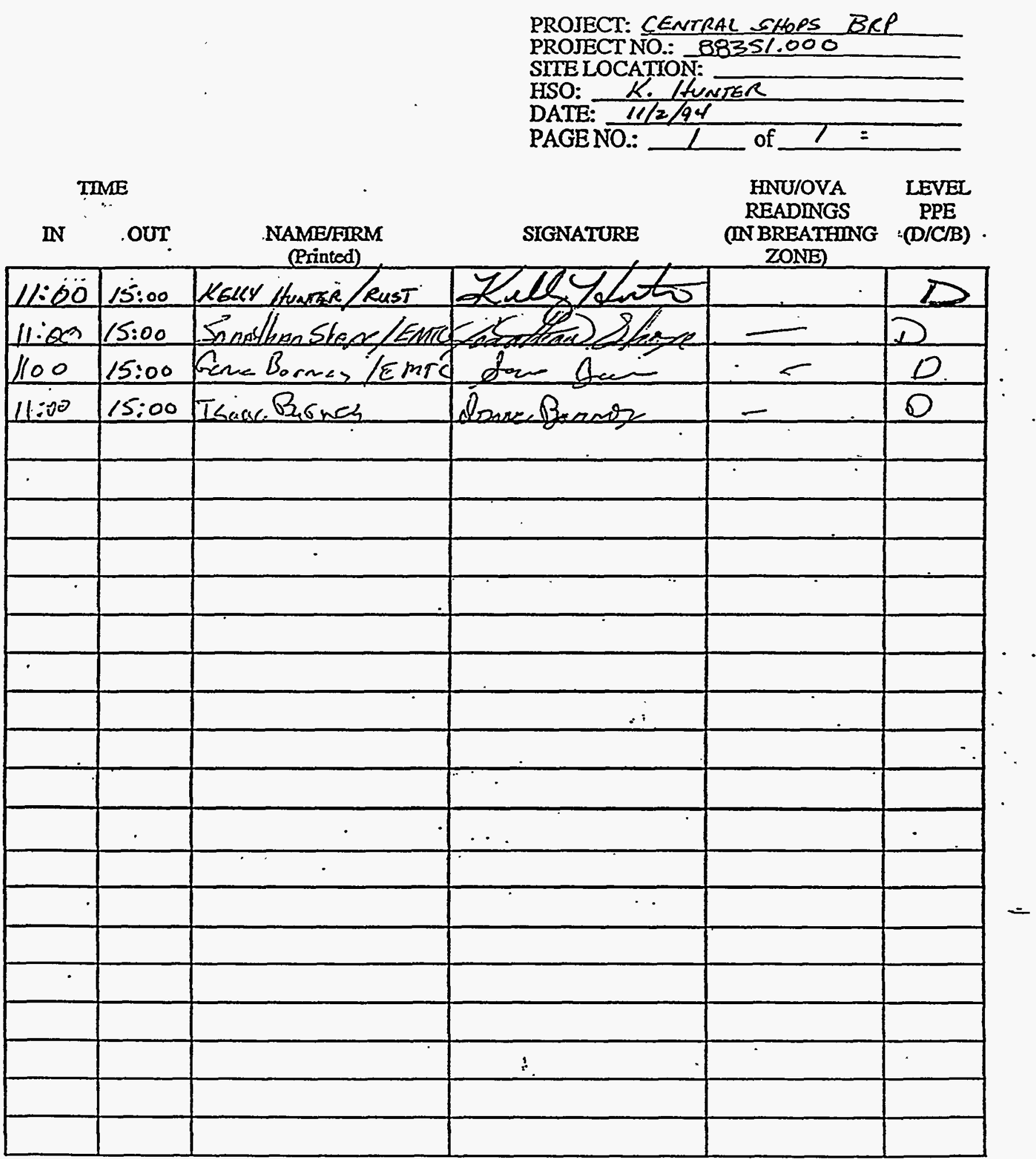

Note: This form is to be completed on a daily basis by all onsite personnel working within the controlled work zone. 
WORK ZONE ENTRY AND EXIT LOG. (JOB EXPOSURE REPORT)

PROJECT: CENTRAL SFOPS BRP

PROJECT NO:: 12081 -

SITE LOCATTON: CENTRAL SHOPS

HSO:

DATE:

PAGENO:

TUNTER

$1 / 3 / 94$

O.: 1 of $1=$

\begin{tabular}{|c|c|c|c|c|c|}
\hline \multicolumn{2}{|c|}{ TIME } & \multirow[b]{2}{*}{$\begin{array}{c}\text { NAME/FIRM } \\
\text { (Pinted) }\end{array}$} & \multirow[b]{2}{*}{ SIGNATURE } & \multirow{2}{*}{$\begin{array}{l}\text { HNU/OVA } \\
\text { READINGS } \\
\text { (INBREATHING } \\
\text { ZONE) } \\
\end{array}$} & \multirow{2}{*}{$\begin{aligned} & \text { LEVEL } \\
& \text { PPE } \\
& \text { (D/C/B) }\end{aligned}$} \\
\hline $\mathbb{N}$ & OUT & & & & \\
\hline $7: 20$ & 1645 & KeaY Hunter/Rust & Kulk & $\cdots$ & Z \\
\hline $7: 30$ & 1645 & Joupthan shopeles & arcledess & 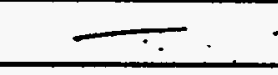 & 0 \\
\hline 230 & 1645 & Isnite Brines & dourse Bx & - & 10 \\
\hline 730 & 1645 & 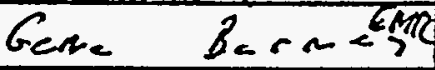 & Saver Sans & - & 17 \\
\hline $8: 00$ & 1645 & Dave Clark/wsre & Danc Clanh & & $D$ \\
\hline $16 \cdot 45$ & & & & & \\
\hline & & & & & \\
\hline & & - & & & \\
\hline & & & & & \\
\hline & & & & & \\
\hline & & & &. & \\
\hline & & & $\therefore$ & & \\
\hline & & & & & \\
\hline & & & & & \\
\hline & & - & & & $\cdot$ \\
\hline & & - & & & \\
\hline & & & & & \\
\hline & & & & & \\
\hline & & & & & \\
\hline & & & & & \\
\hline & & & $:$ & & \\
\hline & & & & & \\
\hline & & & & & \\
\hline
\end{tabular}

Note: This form is to be completed on a daily basis by all onsite personnel working within the controlled work zone. 
WORK ZONE ENTRY AND EXIT LOG (JOB EXPOSURE REPORT)

PROJECT: CS BRP

PROJECT NO.: 12081

SITELOCATION: CEATRAL SLFOPS

HSO: $K$ HyateR

DATE: $11 / 4 / 94$

PAGE NO: of $1=$

TIME

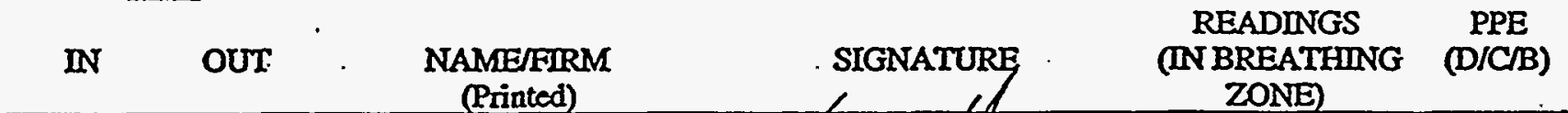

\begin{tabular}{|c|c|c|c|c|c|}
\hline $8: 30$ & 7330 & $L_{\text {ECiY H}}$ Henres & Hellots & & $D$ \\
\hline 930 & 1330 & CBAicer & CBatey & & $D$ \\
\hline $8: 30$ & 1330 & IT Basus & olpornes & & $D$ \\
\hline 60 & 1330 & 6 Buren-s & $\not \operatorname{sen} \sigma$ & & $D$ \\
\hline & & & & & \\
\hline & & & & & \\
\hline & & & & & \\
\hline & & & & & \\
\hline & & & & & \\
\hline & & & & & \\
\hline & & & & & \\
\hline & & & & & \\
\hline & & & & & . \\
\hline & & & & & \\
\hline & & & & & \\
\hline & & & & & \\
\hline & & & & & \\
\hline & & & 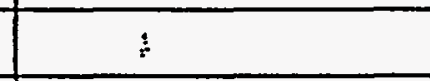 & & \\
\hline & & & & & \\
\hline & & & 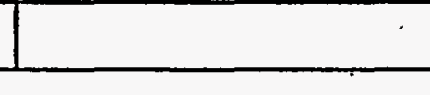 & & \\
\hline
\end{tabular}

Note: This form is to be completed on a daily basis by all onsite personnel working within the controlled work zone. 
WORK ZONE ENTRY AND EXIT LOG . (JOB EXPOSURE REPORT)

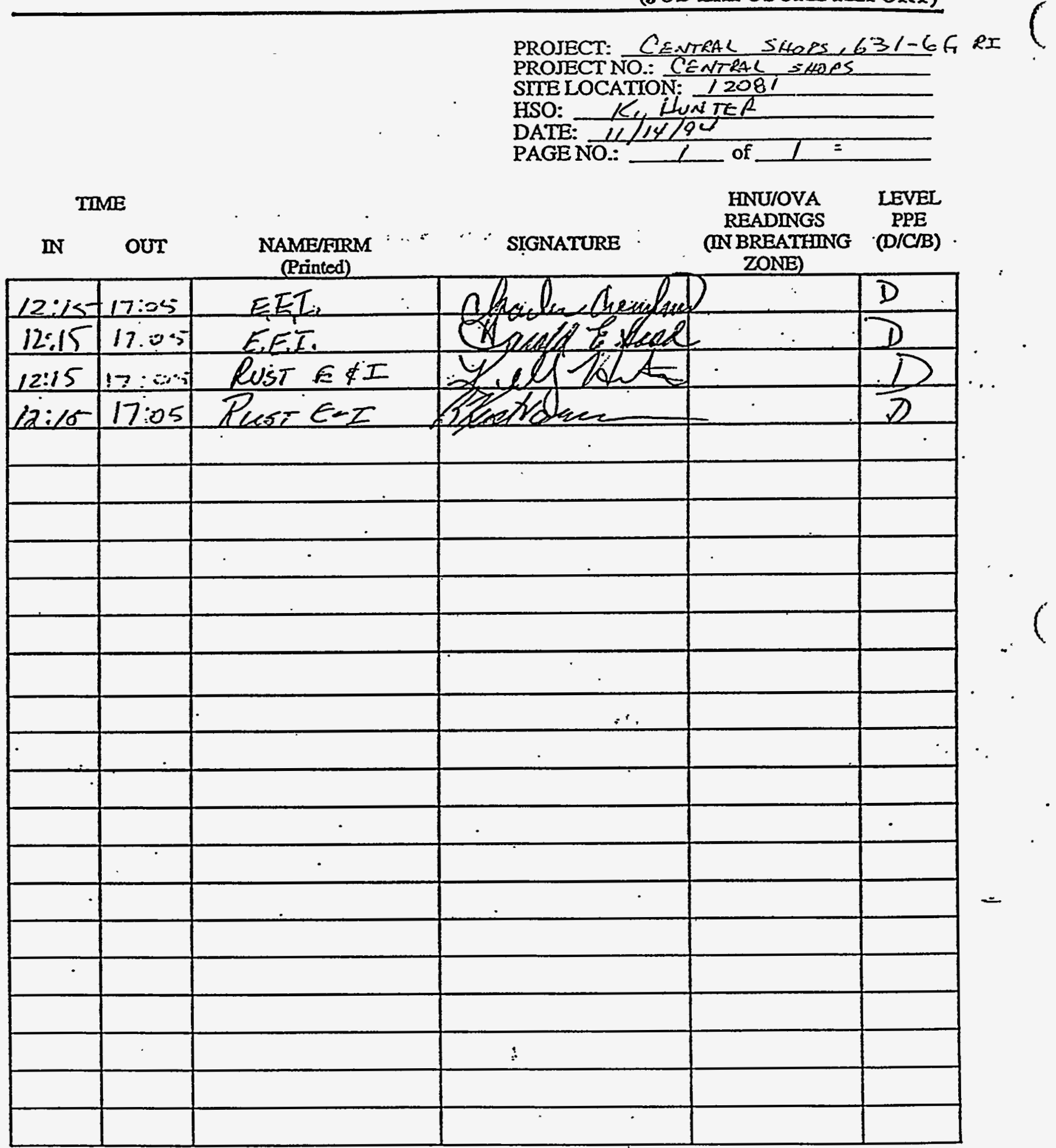

Note: This form is to be completed on a daily basis by all onsite personnel working within the controlled work zone. 
WORK ZONE ENTRY AND EXIT LOG (JOB EXPOSURE REPORT)

PROJECT: CENTRAL SHOPS BRP

PROJECT NO.: 88351.000

STTELOCATION: CENTRAL SA6PS

HSO: K-IfUNTER

DATE: $11 / 22 / 94$

PAGENO: of

TOME

\begin{tabular}{|c|c|c|c|c|c|}
\hline IN & OUT & $\begin{array}{l}\text { NAME/EIRM } \\
\text { (Printed) }\end{array}$ & SIGNATURE & $\begin{array}{l}\text { READINGS } \\
\text { (IN BREATHING } \\
\text { ZONE) }\end{array}$ & PPE \\
\hline $7 ; 00$ & 1330 & E.E.E. & ditulese thece & & \\
\hline 0700 & 1330 & BRés+rouses / $/ R_{L i}$ & Bs & & . \\
\hline 0700 & 1330 & ORENSHALL $/ E E I$ & Ohash anobu= & $\cdot$ & $\therefore \therefore$ \\
\hline & & & & & \\
\hline & & & & & \\
\hline & & & & & \\
\hline & & . & & & \\
\hline & & & & & \\
\hline & & & . & & \\
\hline & & . & $\cdot$ & & \\
\hline & & & $\therefore$ & & \\
\hline & & & . & & \\
\hline & & & & & \\
\hline & & - & . & & - \\
\hline & & - & & & \\
\hline & & & . & & \\
\hline & & & & & \\
\hline & & & & & \\
\hline & & & & . & \\
\hline & & & 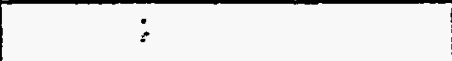 & & \\
\hline & & & & & \\
\hline & & & & & \\
\hline
\end{tabular}

Note: This form is to be completed on a daily basis by all onsite personnel working within the controlled work zone. 
WORK ZONE ENTRY AND EXIT LOG (JOB EXPOSURE REPORT)

PROJECT: CENTRAL SITURS BRP

PROJECT NO: i 1208 ;

SITE LOCATION: C.ENTRAL 5 HORS

HSO: K. XW:

DATE: $11 / 30 / 94$

PAGENO.: of

TIME

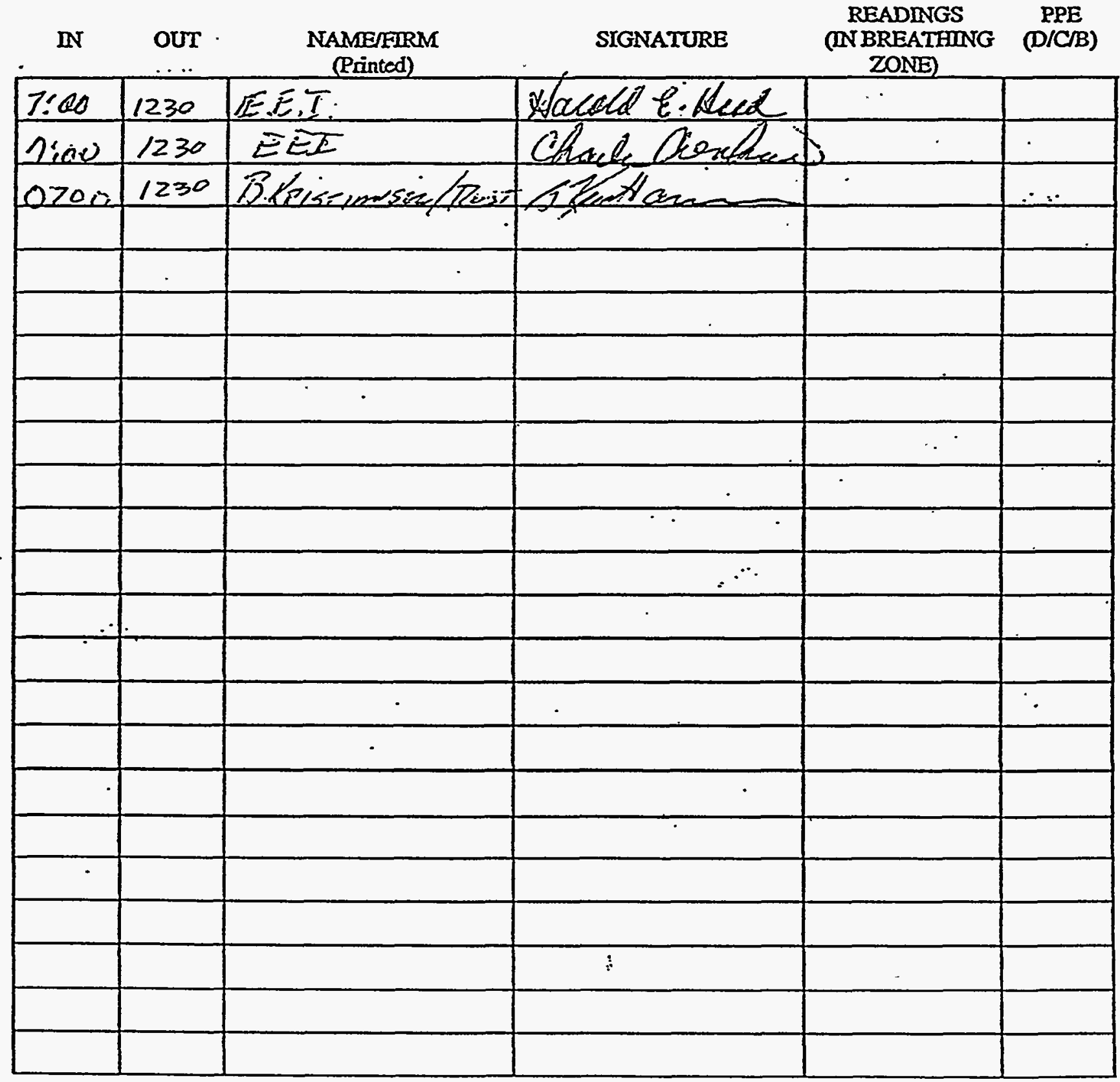

Note: This form is to be completed on a daily basis by all onsite personnel working within the controlled work zone. 


\title{
Appendix F
}

\section{Well Development Forms}

\author{
CBR-4 \\ CBR-5 \\ CBR-6
}


CBR-4 


\section{DEVELOPMENT SHEET.}

WंELL \# CB.R-T.3

developed By Frank Cooper

DEVELOPMENT OVERंSTGHT

Rust.

DATE STARTED 9 NOV.94

STARTING WATER LEVEL $29 \mathrm{ff}$

STARTING FLOW METER READING $\frac{\mathrm{N} / \mathrm{A}}{\ddots}$

STARTING WELL YIELD (AFTER BAIING) A. $35 \mathrm{Gal} P \mathrm{H}^{\text {r }}$

DATE FINTSEED 14 NVV 94

FDNAL WATER LEVEL $\quad 41,5$

FINAL FLOW METER READING MA

TOTAL VOLUME OF WATER REMOVED $\quad 425$

FINAL WELL YDELD $\frac{35}{41 / 2}$

HOURS PUMPEOU

N/P

HOURS BLOWI $\quad 6 \frac{1}{2}$

HOURS OTHER Swabbing 1 .

COMMENTS

FORM MUST BE TURNED IN THE FIRST WORKING DAY AFTER DEVEI.OPMENT IS (O:.TLLTEDI)

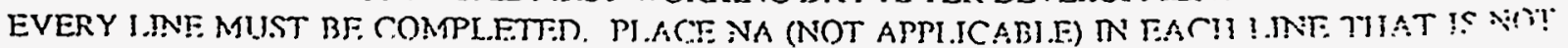

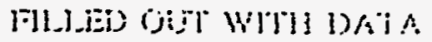


OAR 20.4

SAVANNAH RIVER PLANT WELL DEVELOPMENT REPORT

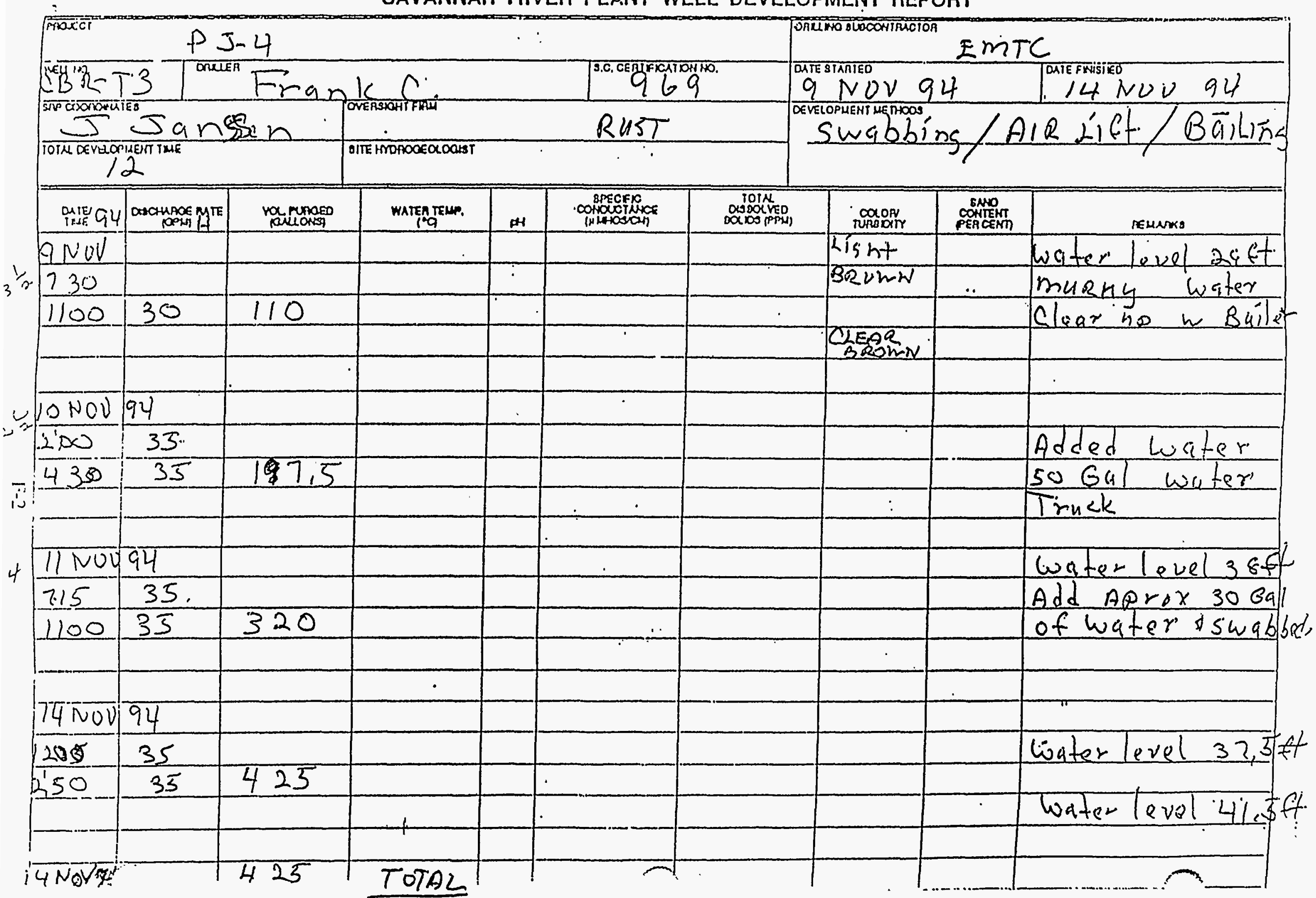




\begin{tabular}{|c|c|c|}
\hline $\begin{array}{l}\text { WESTINGHOUSE SAVANNAH RIVER COMPANY } \\
\text { GROUNOWATER MONITORING WELL } \\
\text { INSTALLATION } \\
\text { SRS MONITORING WELL INSTALLATION REPORT }\end{array}$ & $\begin{array}{l}\text { Manuat: } \\
\text { Chapter: } \\
\text { Page: } \\
\text { Effective Date: } \\
\text { Organizatlon: }\end{array}$ & $\begin{array}{r}\text { DPSOi' } 254 \\
5 \text { (Draft } 1) \\
7 \text { of } 10 \\
8 / 1 / 89 \\
\text { Environmental } \\
\text { Protection Sectlon }\end{array}$ \\
\hline
\end{tabular}

WELLDEYELLOMENT

Well number $C$ B.R, $, T, 3, i$, Developed by Frank Cooper

Date started $9111,9.4$
Oversight

DÉVELOPMENT METHOD:

Bailing

Swabbing and surging

Air lift

Pumping

Total hours

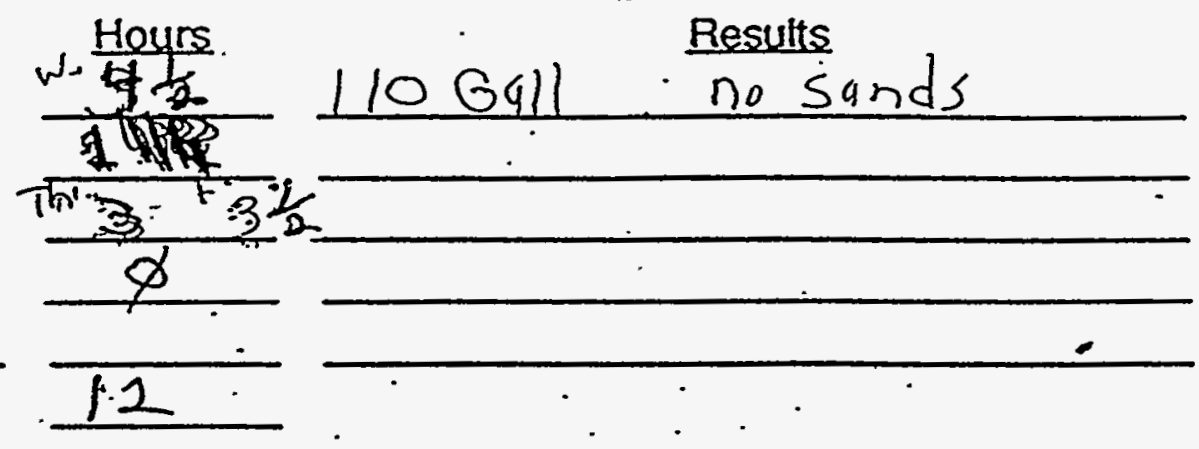

Type and quantity of additives (including water) placed in well during development:

- Aprox 30 Gal of water did not Seem

$\frac{\text { to } h \mathrm{e} \backslash \mathrm{Q},}{\mathrm{Estimated} \text { volume of water removed during development }(\mathrm{gall}) \cdot-425}$

Start of development
$\begin{aligned} & \text { End of development } \\ & \text { Well yield (gpm) }\end{aligned}$

Well development comments cater does not cLtaR UP.

Verified by

Report prepared by

Date

1

Date

1

$\cdots$

$F-3$ 


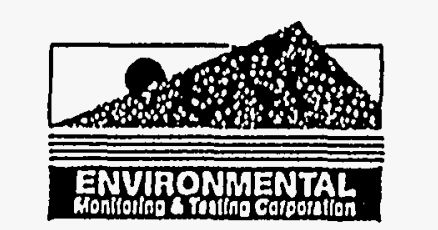

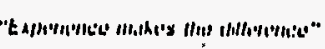

P.O. Bux 750

Now Elluiloll, SC 20000

(घ03) $05 \% \cdot 2 \% 18$

i

WELL DE:VELOPMENT FORM

HEIL:CDR T-3 LOCATION:C Lay hot

DATE STARTED: 9 NOU 94

TIME STARTED: I:30:

DATE FINISHED:1YNOV 94

TIME FINISHED: 15,00

PAGE 1 OF

TYPE OF DEVELOPMENT

WATER QUALITY

COMMENTS

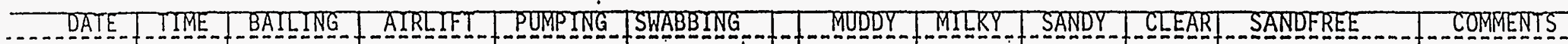

\begin{tabular}{|c|c|c|c|c|c|c|c|c|c|c|c|}
\hline ....DAIE & FIMPE. & BAILING & AIRIIET & PUNPING & TSWABBENG & MUDOPY & FIIIKKY & FSANDY & CLEEA & SANDFEEE & - CONMENTS \\
\hline 300094 & 730 & $V$ & & & & $V$ & & & & 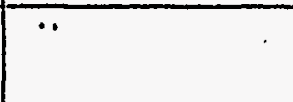 & Wuśs \\
\hline 011094 & $\begin{array}{l}100 \\
430\end{array}$ & & $\checkmark$ & & $\checkmark$ & & 7 & & & & Chesa $10_{0}$ \\
\hline $1 \mathrm{Nu} 9$ & $\begin{array}{l}715 \\
1800 \\
\end{array}$ & & 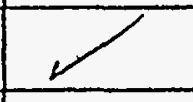 & & $\swarrow$ & & & & & & $\begin{array}{l}\text { poss ne } \\
\text { don- isp }\end{array}$ \\
\hline & & & & & & & & & & 7 & \\
\hline $4 N 0 \cup 94$ & 12,50 & $\sim$ & & & $r$ & & & & n & & Clequ bmond \\
\hline 4 Nov 94 & 1450 & $\sqrt{ }$ & & & $\checkmark \quad:$ & & & & 2 & & 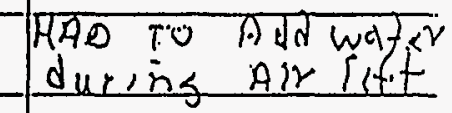 \\
\hline & & & & & & & & & & & \\
\hline & & & & & & & & & & . & \\
\hline & & & & & & & & & & & \\
\hline & & & & & & & & & & & \\
\hline
\end{tabular}

TOTAL NUMBER OF HOURS DEVELOPMENT 3 M

RIG USED 9

INSPECTORS SIGNATURE:

NAME OF DEVELOPER: Frank Cooper

$\ddot{\square}$

f 


\section{CBR-5}


DEVELOPMENT SHEET

$\therefore \quad$ WELL \# CB P -TL

DEVELOPED By Frank Cooper DEVELOPMENT OVERSIGHT

Rust

DATE STARTED $9 \mathrm{NOU} 94$

STARTING WATER LEVEL $41 \mathrm{ft}$

STARTING Bálling $1 / 2 \cdot G a l$

STARTING WELL YIELD (AFTER BAILING)

DATE FINISHED IS NUN 94 :

FINAL WATER LEVEL $30 \mathrm{ft}$

FINAL FLOW METER READING …N/A : 152

TOTAL VOLUME OF WATER REMOVED

Gal

FINAL WELL YIELD A, 30 GPA

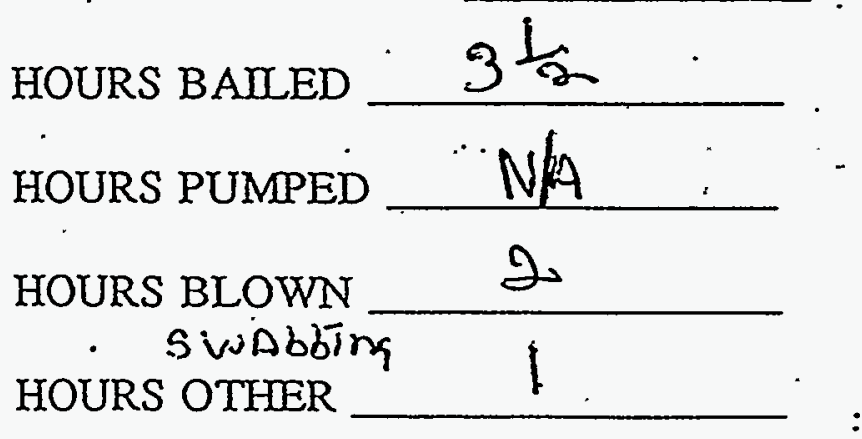

COMMENTs Had to Add water to weill could net air Lift

FORM MUST BE TURNED IN THE FIRST WORKiNG DAY AFTER DEVELOPMENT IS COMPI.ETHD. IEVERY LINE MUIST BE COMPLETED. PI.ACE NA (NOT APPLICA.R!EE) IN EACH L.JNE THAT IS Ni:

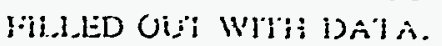

$F-5$ 
SAVANNAH RIVER PLANT WELL DEVELOPMENT REPORT

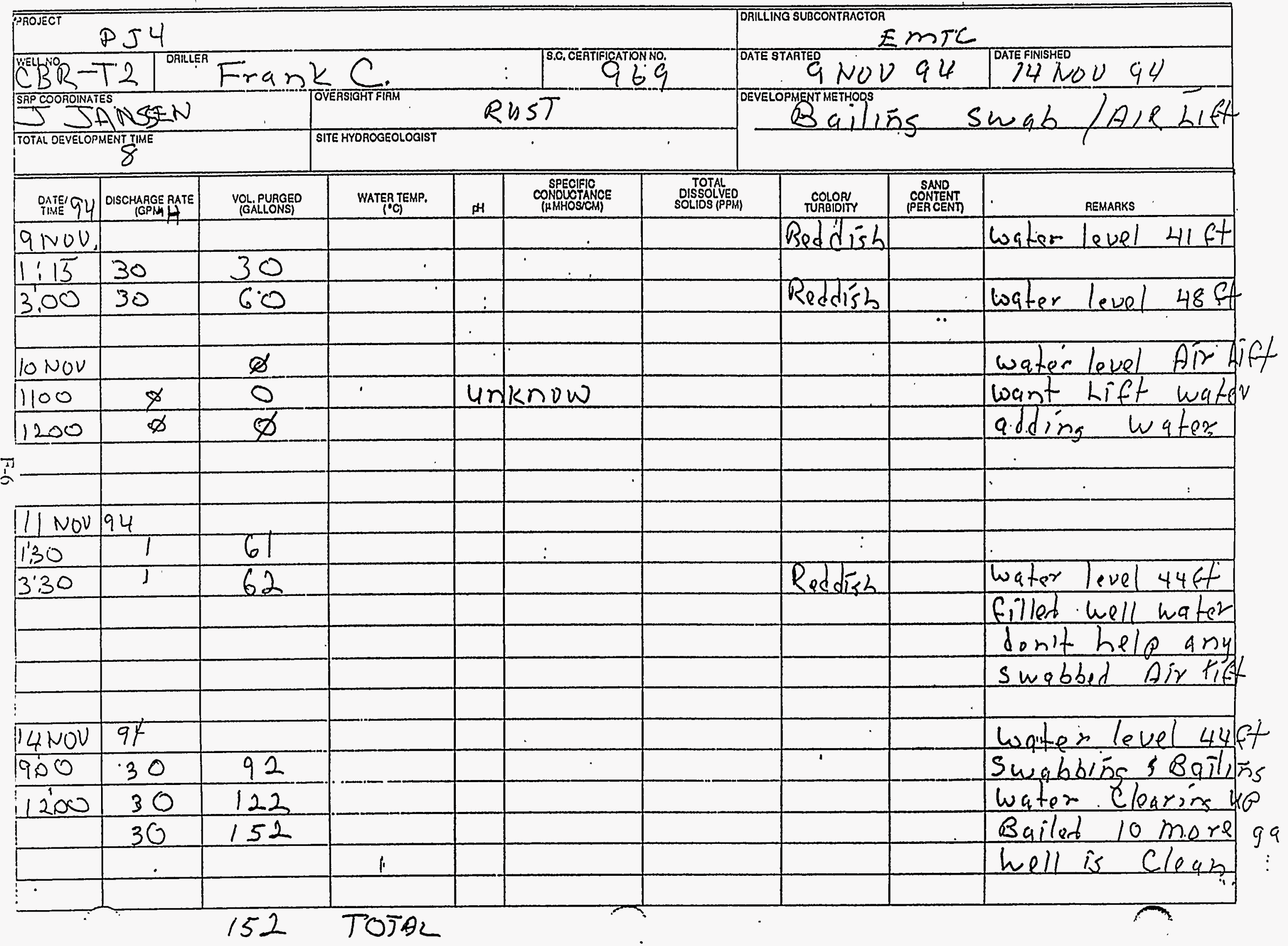




\begin{tabular}{|c|c|c|}
\hline $\begin{array}{l}\text { WESTINGHOUSE SAVANNAH RIVER COMPANY } \\
\text { GROUNDWATER MONITORING WELL } \\
\text { INSTALLATION } \\
\text { SRS MONITORING WELL INSTALLATION REPORT }\end{array}$ & $\begin{array}{l}\text { Manuat: } \\
\text { Chapter: } \\
\text { Page: } \\
\text { Effective Date: } \\
\text { Organization: }\end{array}$ & $\begin{array}{r}\text { DPSOi: } 254 \\
5 \text { (Draft } 1) \\
7 \text { of } 10 \\
8 / 1 / 89 \\
\text { Environmental } \\
\text { Protection Section }\end{array}$ \\
\hline
\end{tabular}

\section{WELLDEVELQPMENT}

well number $E B, B, 4,1, D_{2}$ Developed by. Frank Cooper
Date started $91 \mathrm{NOV}, 94$
Oversight
Date completed 14 NoV; 94. RUST

\section{DEVELOPMENT METHOD:}

Bailing

Swabbing and surging

Air lift

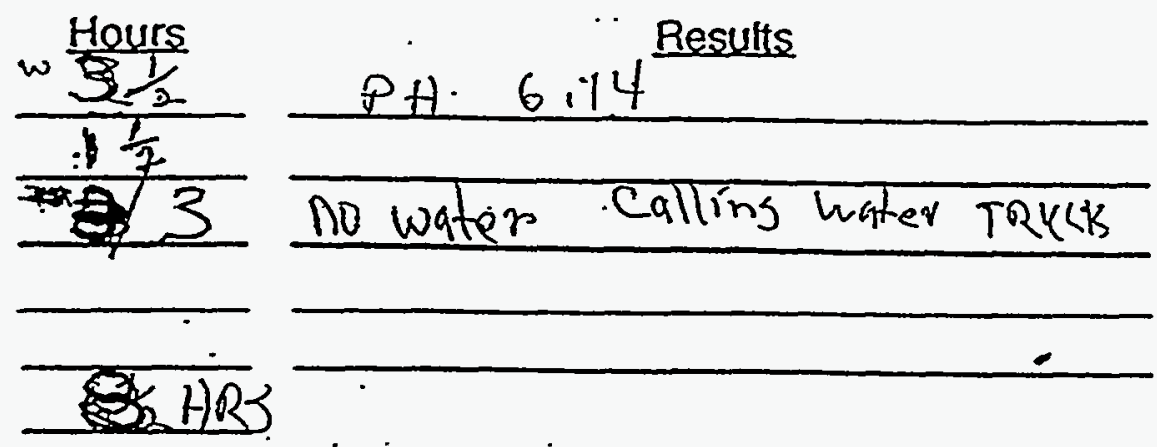

Total hours

Pumping

Type and quantity of additives (including water) placed in well during development:

- Cuater Aprox $50 \mathrm{Gal} 7 \mathrm{Tta}]$

Estimatéd volume of water removed during development (gal)

$15+69$.

Start of development
$\begin{aligned} & \text { End of development } \\ & \text { Well yield (gpra) } 4 .\end{aligned}$ Well development comments Sould rot air lift, boiled qood
o Cleane?

Verified by

Date

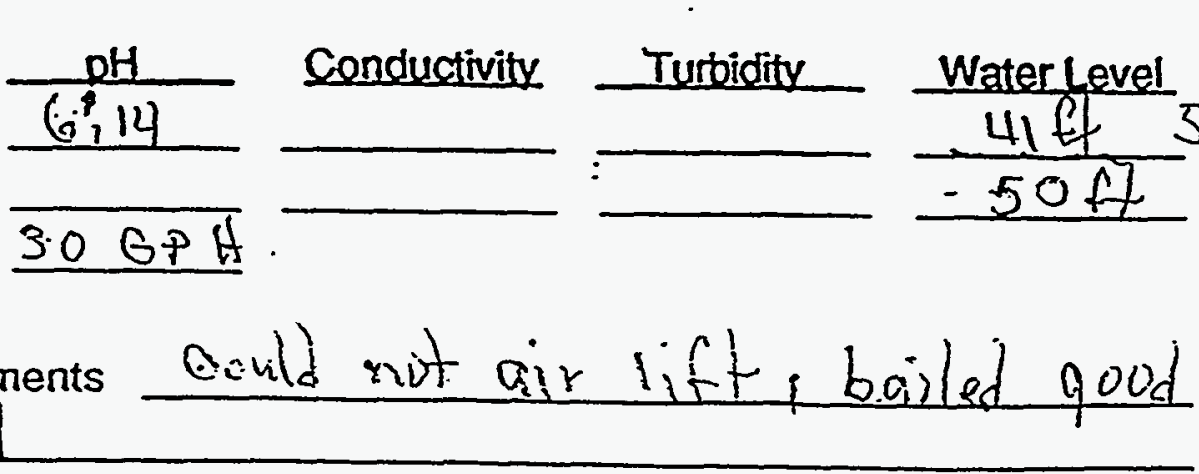

Report prepared by

F-7

Date 1 


\section{CBR-6}


DEVELOPMENT SHEET

WELL \#CBP-T1

DEVELOPED BY Frank Cooper

DEVELOPMENT OVERSIGHT_ RUST

DATE STARTED 9 NOV 94.

STARTING WATER LEVEL $48 \mathrm{ft}$

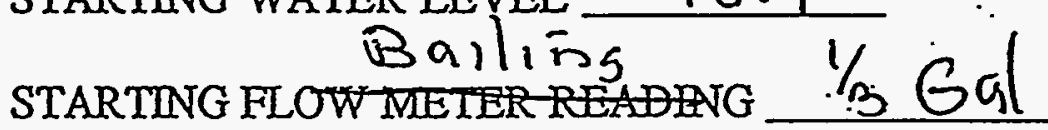

STARTING WELL YIELD (AFTER BAILTNG) _. 15

DATE FINISHED 14 NOD 94.

FINAL WATER LEVEL 53,5

FINAL FLOW METER READING_ NA

TOTAL VOLUME OF WATER REMOVED . 202

FINAL WELL YIELD $35 \mathrm{GPH}$

HOURS BAILED

$2 H R$,

HOURS PUMPED W/A

HOURS OTHER Swabbed. IH?

COMMENTs Had to add water to well could

FORM MUST BE TURNED IN THE FIRST WORKING DAY AFTER DEVELOPMENT IS COMPLETED. EVERY LINE MUST IEE COMPI ETED. PLACE N DIILED OUI WIII UATA. 


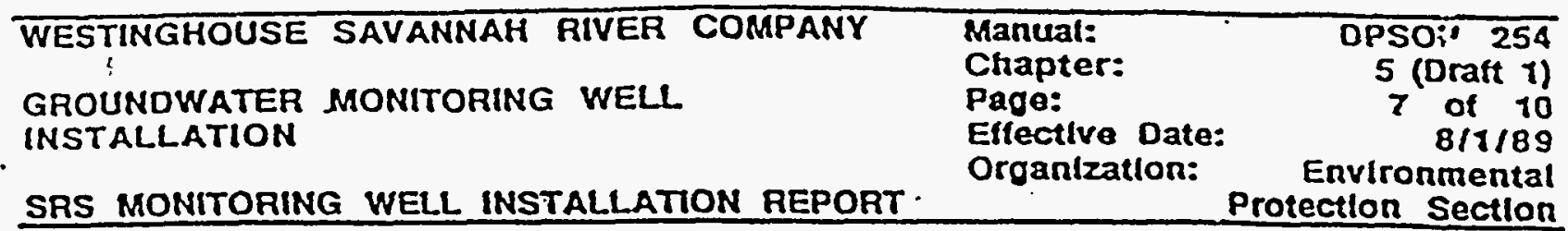

\section{WELLDEVELOPMENT}

Well number $E B, B$, Til, i, Developed by triank Souger
Date started $9, \mathrm{NDO}, 94$
Date completed 14 ,NOU, 94

.. Oversight

Ru(s)

DEVELOPMENT METHOD:

Bailing

Swabbing and surging

Air lift

Pumping
Hours

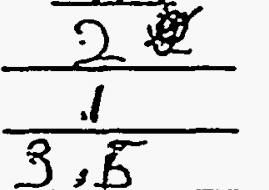

Light Sgind,

nowater/ ealling tor water tanks

Total hours

$6 \frac{1}{2}$

Type and quantity of additives (inctuding water) placed in well during development:

- Noné szow to Recharser filled loell yo

QTime Aprox GD Gall. water

Estimated volume of water removed during development (gal) $20 \cdot 2$

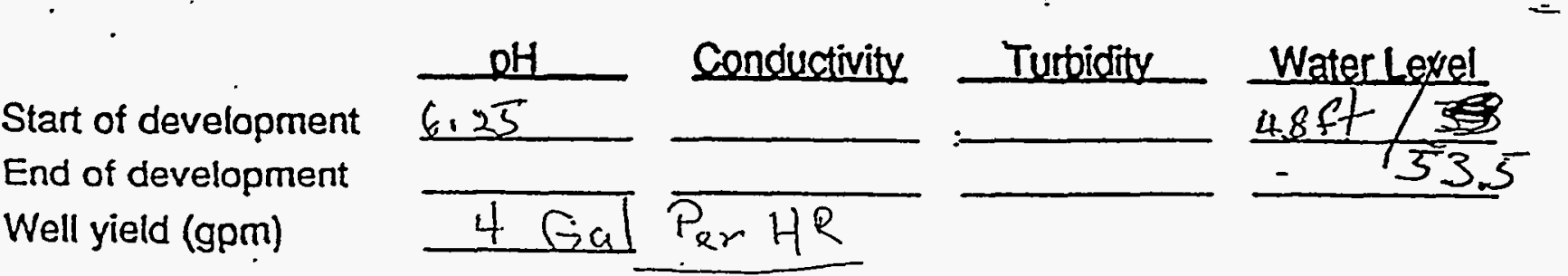

Well development comments sivas Qe charge water level 47 feet. fillad inall wits water swabbed to mis jui Clireris

Verified by

Date C.
Report prepared by

F-11

Date

1 


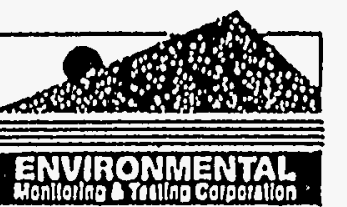

WELL DEVELOPMENT FORM

WEI.L:C.BiR T1

LOCATION: C. AREO
DATE STARTED: 9 NDV 94

TIME STARTSB: 11:00 $=1: 06$

DATE FINISHED: 14 NOV 94 PAGE 1 OF 4

TIME FINISHED: $\mathbf{5}, 00$

TYPE OF DEVELOPMENT.

WATER QUALITY

COMMENTS

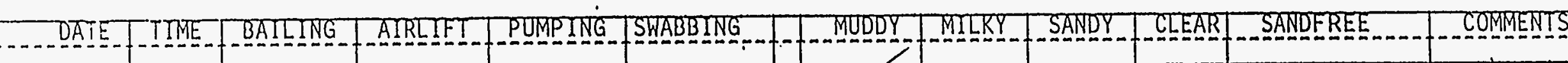

\begin{tabular}{|c|c|c|c|}
\hline DAIE_ & FIIME & BAILING & AIRLIEI \\
\hline$N \cup V^{\prime} i y$ & 1100 & $\checkmark$ & \\
\hline 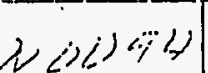 & $1<0$ & $U$ & \\
\hline 1,$10 ;$ & 460 & & 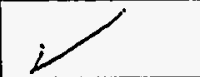 \\
\hline$\alpha^{\prime \prime}$ & $\therefore$ & & $\swarrow$ \\
\hline $1 N 00$ & $3 \% 0$ & r & \\
\hline & 4.45 & $\checkmark$ & \\
\hline & & & \\
\hline & & & \\
\hline 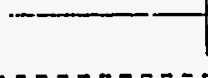 & & & \\
\hline
\end{tabular}

TOTAL NUMBER OF HOURS DEVELOPMENT

NAME OF DEVELOPER: Fiank RODPOr

RIG USED

(2)

water (eve)

48 ft

wat? 3 का

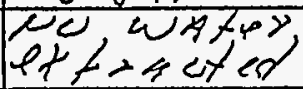

UERY IITlP

watar

$4 \mathrm{Gal} / H \times$

CLEATED पू

Goud bit not

CLEAO

INSPECTORS SIGNATURE:

$1100-1.00$ 24R. 


\section{Appendix G}

\section{Groundwater Sampling Information}




\section{Phase I (12/5/94)}

\section{CBR-4}

CBR-5

CBR-6 


$$
\begin{gathered}
\text { Appendix G } \\
\text { Summary of Groundwater Sampling } \\
\text { Phase I }(12 / 15 / 94)
\end{gathered}
$$

\begin{tabular}{|c|c|c|c|c|c|}
\hline $\begin{array}{c}\text { Sample } \\
\text { Location }\end{array}$ & $\begin{array}{c}\text { Sample } \\
\text { Number } \\
\end{array}$ & $\begin{array}{c}\text { Date } \\
\text { Sampled }\end{array}$ & $\begin{array}{c}\text { Sample ID } \\
\text { Number }\end{array}$ & $\begin{array}{c}\text { Analyte } \\
\text { Code }\end{array}$ & Identifier \\
\hline CBR-5 & 01 & $12 / 5 / 94$ & 102519 & 2,3 & Normal \\
\hline CBR-5 & $01 E$ & $12 / 1 / 94$ & 103798 & 2,3 & Rinsate \\
\hline CBR-5 & $01 \mathrm{C}$ & $12 / 5 / 94$ & 102520 & 2,3 & Field Blank \\
\hline CBR-4 & 01 & $12 / 5 / 94$ & 102521 & 2,3 & Normal \\
\hline CBR-4 & $01 \mathrm{~A}$ & $12 / 5 / 94$ & 102522 & 2,3 & Duplicate \\
\hline CBR-4 & $01 D$ & $12 / 5 / 94$ & 102522 & 2,3 & Split \\
\hline CBR-6 & 01 & $12 / 5 / 94$ & 103799 & 2,3 & Normal \\
\hline
\end{tabular}

Analyte Codes for Groundwater Sampling:

2. TCLTTAL w/TIC

3. Tritium

QA/QC Sample Codes:

A Duplicate sample

C Field Blank

D Split sample

E Rinsate blank 
Phase II (12/28/94)

CBR-4

CBR-5

CBR-6 


\author{
Appendix $\mathrm{G}$ \\ Summary of Groundwater Sampling \\ Phase II $(12 / 28 / 94)$
}

\begin{tabular}{|c|c|c|c|c|c|}
\hline $\begin{array}{l}\text { Sample } \\
\text { Location }\end{array}$ & $\begin{array}{l}\text { Sample } \\
\text { Number }\end{array}$ & $\begin{array}{c}\text { Date } \\
\text { Sampled }\end{array}$ & $\begin{array}{c}\text { Sample ID } \\
\text { Number }\end{array}$ & $\begin{array}{c}\text { Analyte } \\
\text { Code }\end{array}$ & Identifier \\
\hline CBR-5 & 01 & $12 / 28 / 94$ & 102560 & 2,3 & Normal \\
\hline CBR-5 & $01 E$ & $12 / 28 / 94$ & 102561 & 2,3 & Rinsate \\
\hline CBR-4 & 01 & $12 / 28 / 94$ & 102562 & 2,3 & Normal \\
\hline CBR-6 & 01 & $12 / 28 / 94$ & 102559 & 2,3 & Normal \\
\hline
\end{tabular}

Analyte Codes for Groundwater Sampling:

2. TCL/TAL w/TIC

3. Tritium

QA/QC Sample Codes:

E Rinsate blank 


\section{Appendix H}

\section{Field Permeability Testing}

\section{Falling and Rising Head Slug Tests For:}

CBR-4

CBR-5

CBR-6 
CBR-4 


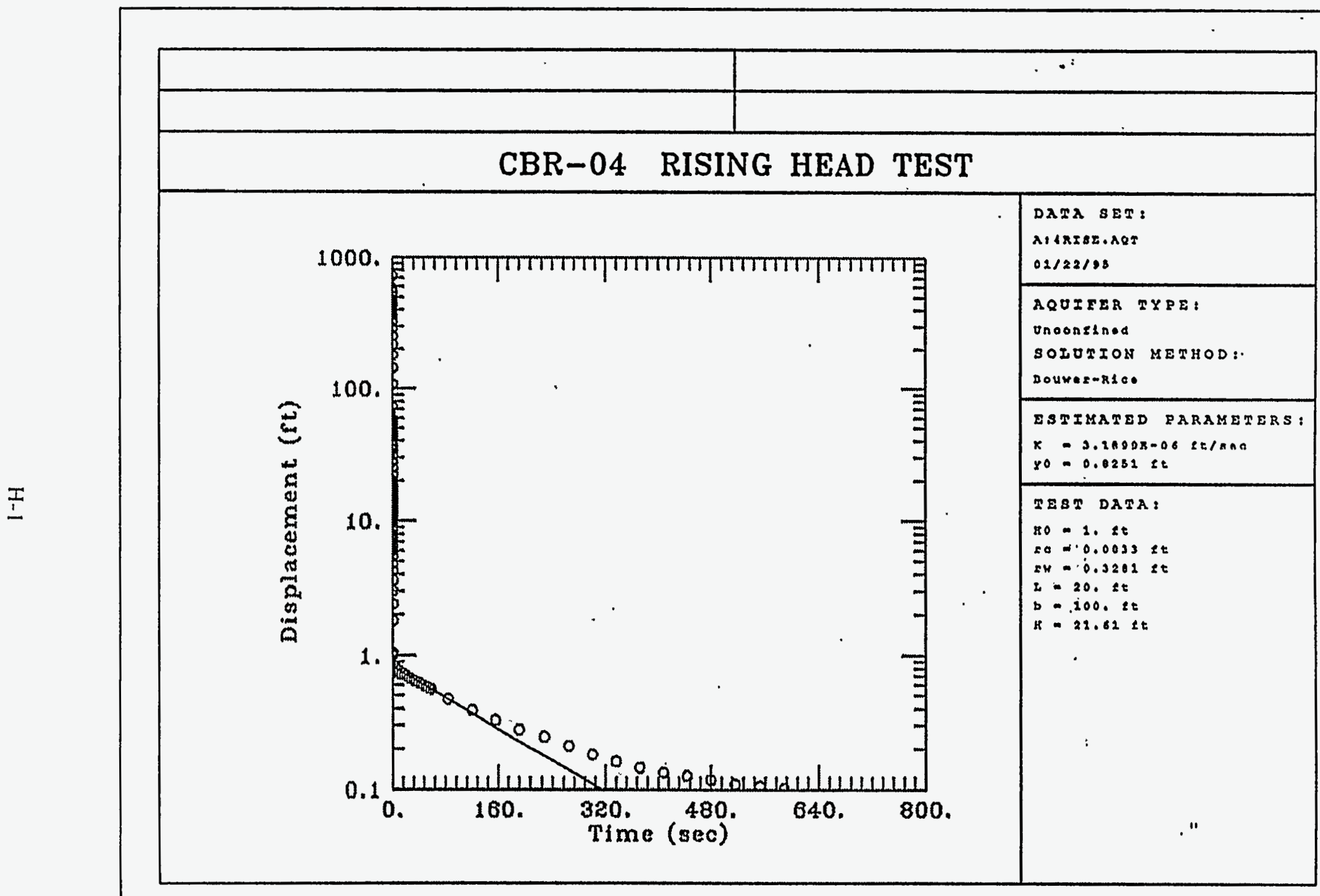




\section{CBR-5}




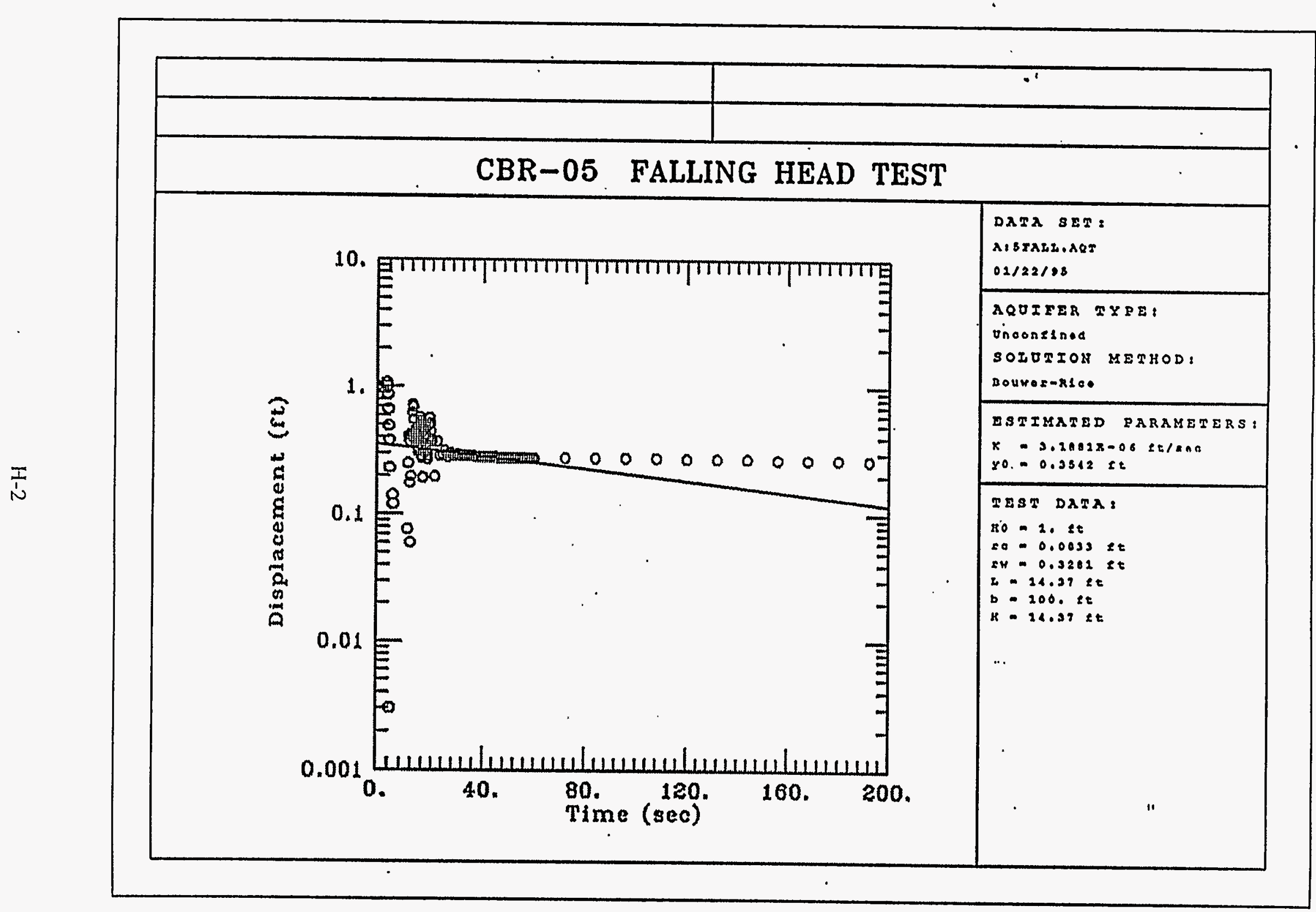




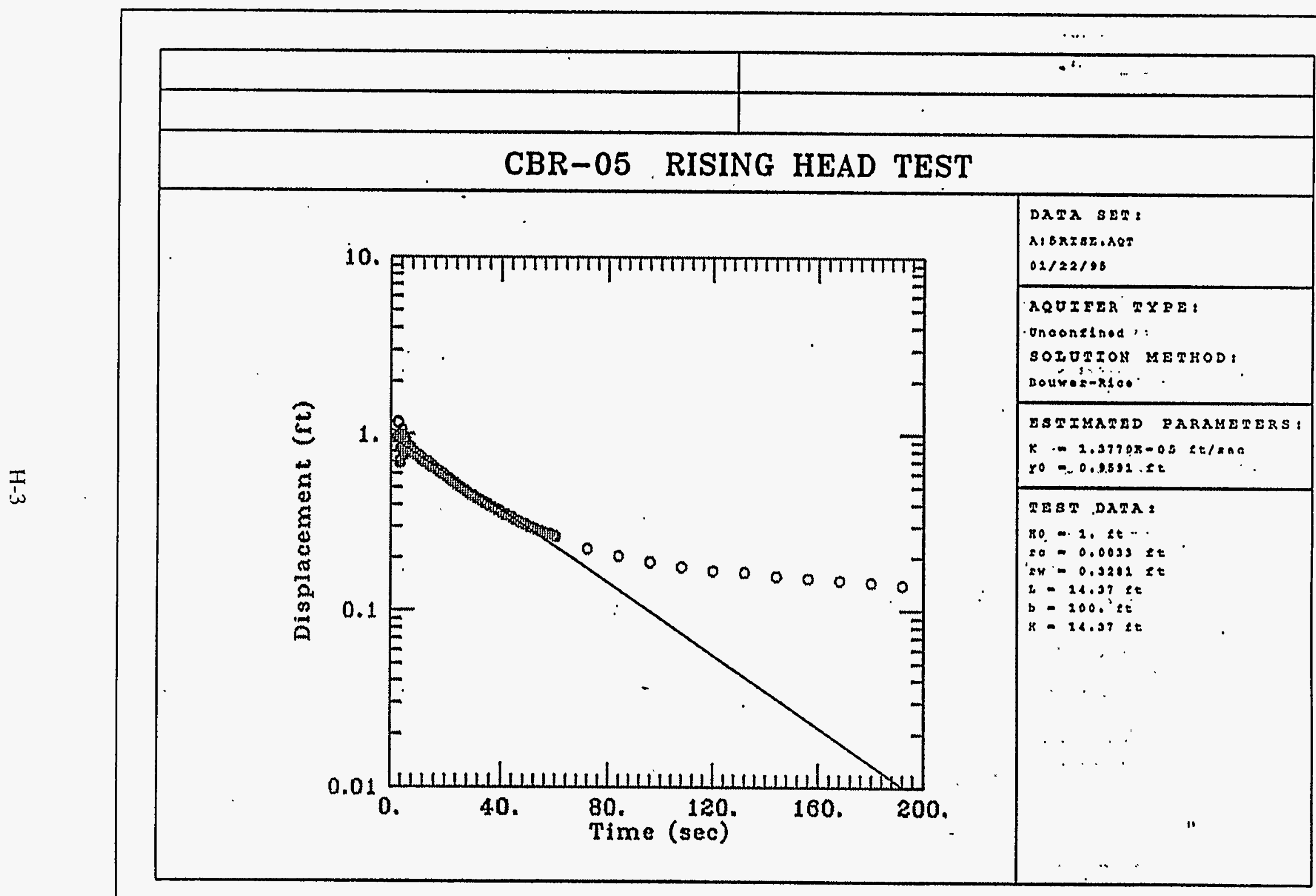


(

CBR-6

$=$

1

$-$

1 


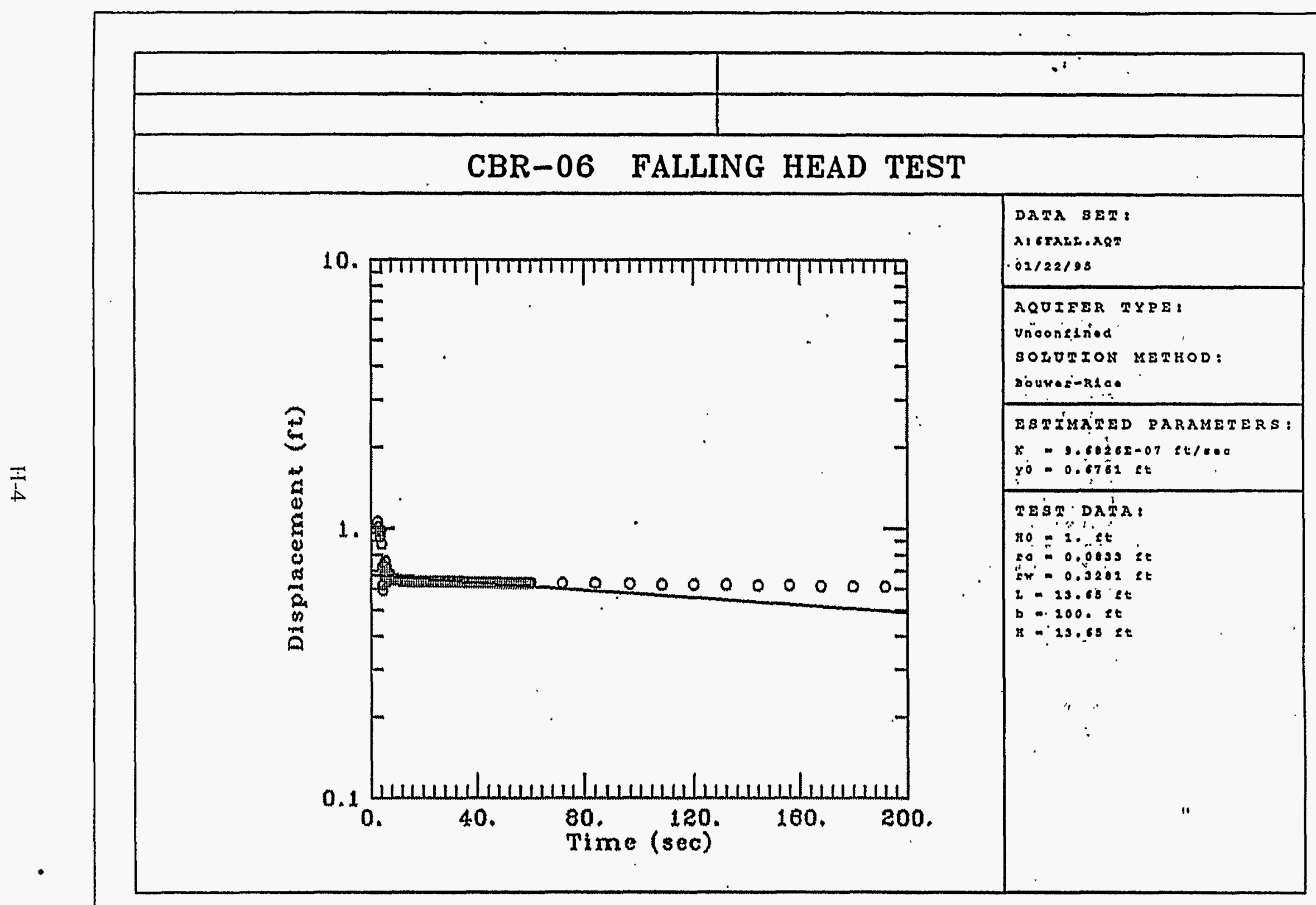




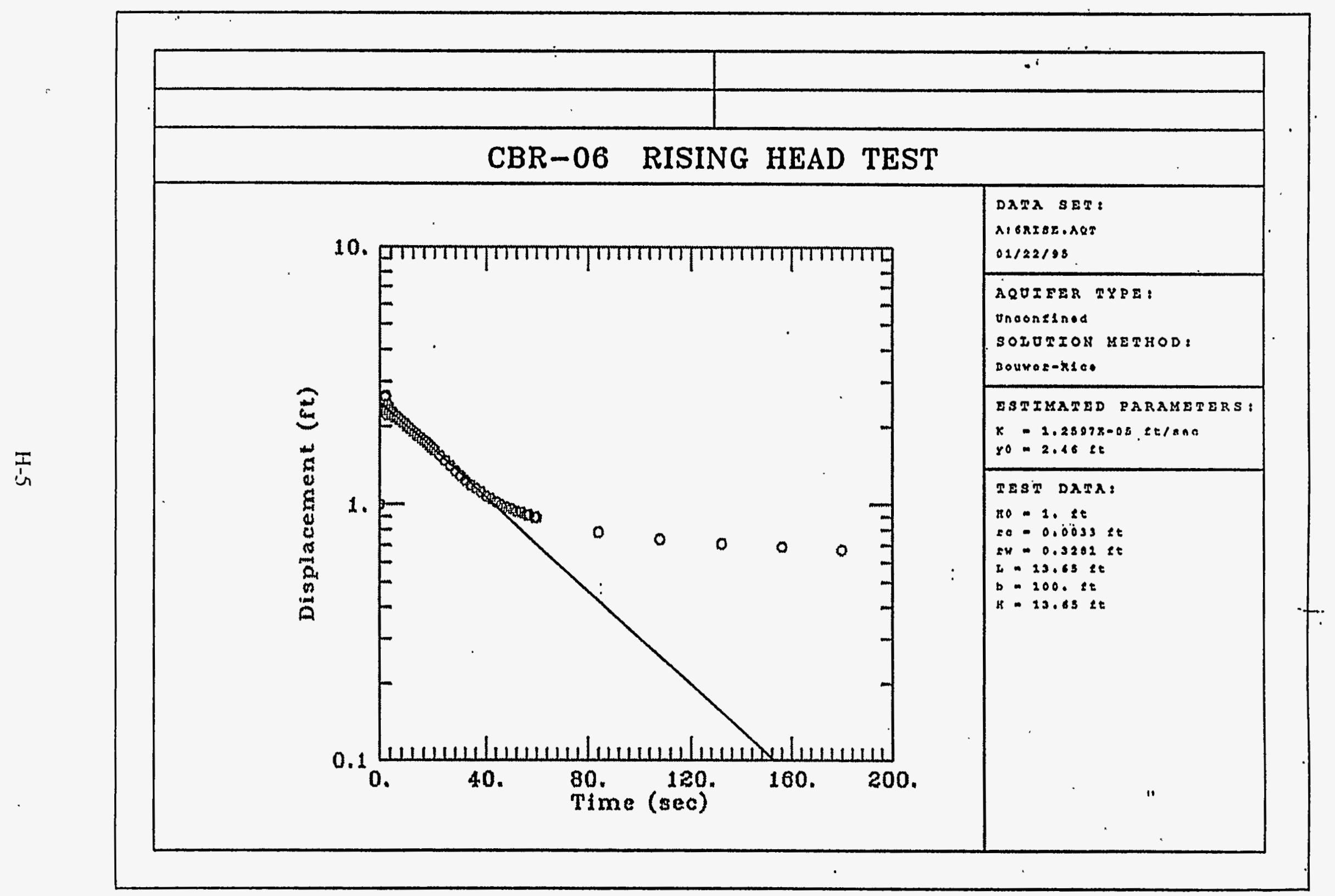




\section{Appendix I}

Surface Water/Sediment Sampling Information 
Field Readings for Surface Water/Sediment Sampling 12/7/94

\begin{tabular}{||c|c|c|c||}
\hline Sample Number & $\begin{array}{c}\text { Surface Water } \\
\text { Temperature }\end{array}$ & $\begin{array}{c}\text { Dissolved Oxygen } \\
\text { (mg/l) }\end{array}$ & $\mathrm{pH}$ \\
\hline \hline CS6G-29 & $13.4^{\circ} \mathrm{C}$ & 7.85 & 10.51 \\
\hline CS6G-30 & $66^{\circ} \mathrm{F}$ & 9.40 & 10.50 \\
\hline CS6G-31 & $73^{\circ} \mathrm{F}$ & 8.00 & 9.68 \\
\hline CS6G-32 & $15.8^{\circ} \mathrm{C}$ & 6.63 & 9.22 \\
\hline CS6G-33 & $16.0^{\circ} \mathrm{C}$ & 5.38 & 6.61 \\
\hline
\end{tabular}

